DEPARTMENT OF THE INTERIOR

UNITED STATES GEOLOGICAL SURVEY

GEORGE OTIS SMITH, DIRECTOR

WILLIAM O. JENKINS

Professional Paper 81

\title{
CRETACEOUS DEPOSITS OF THE EASTERN GULF REGION
}

AND

\section{SPECIES OF EXOGYRA FROM THE EASTERN GULF REGION AND THE CAROLINAS}

BY

LLOYD WHLIAM STEPHENSON

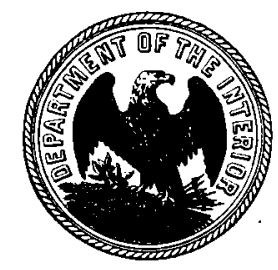

WASH I NGTON

GOVERNMENT PRINTING OFFICE 1914 



\section{CONTENTS.}

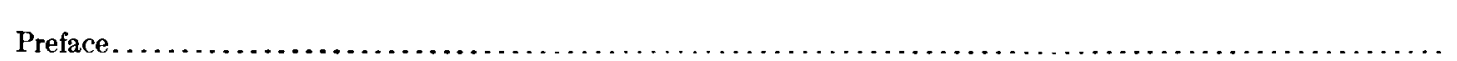

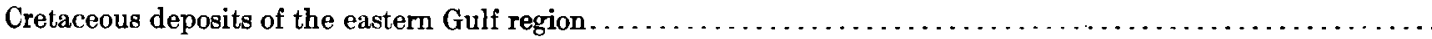

Object and scope of the work.

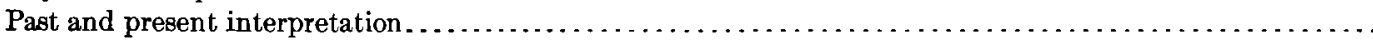

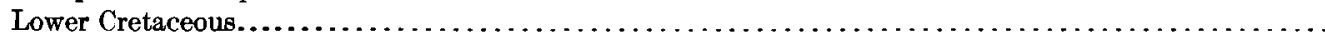

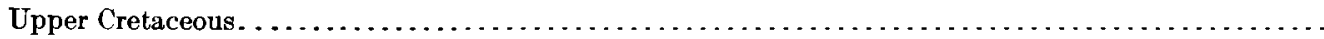

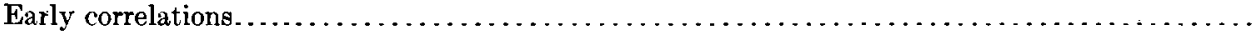

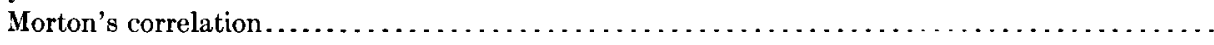

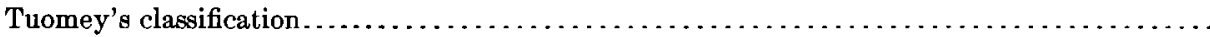

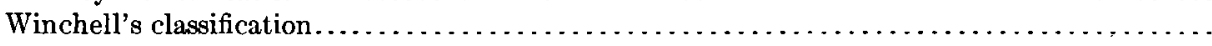

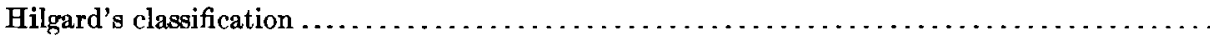

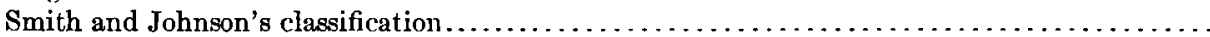

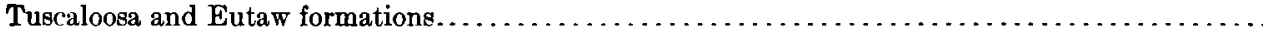

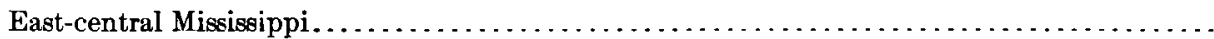

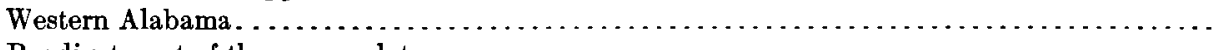

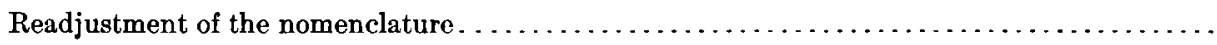

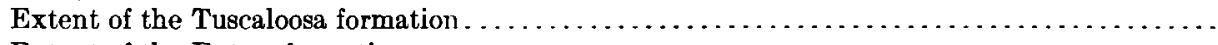

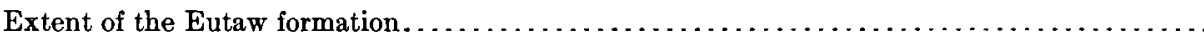

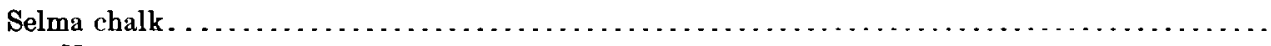

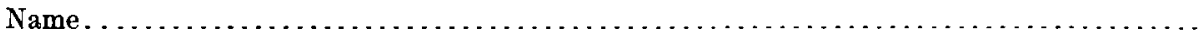

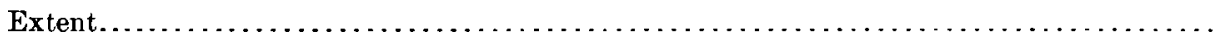

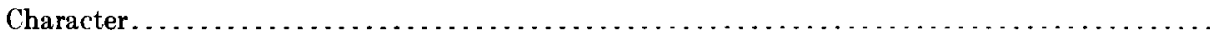

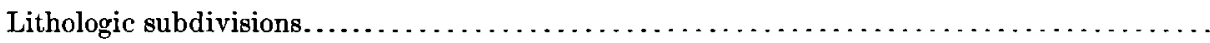

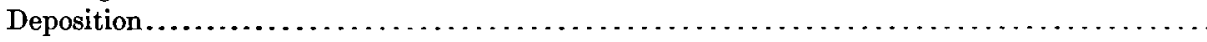

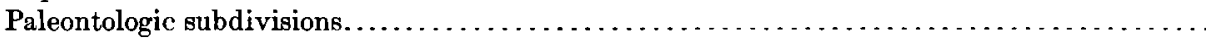

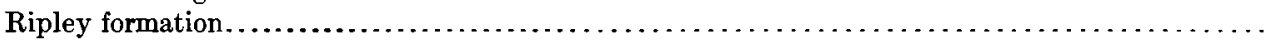

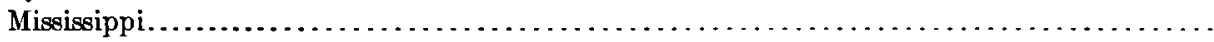

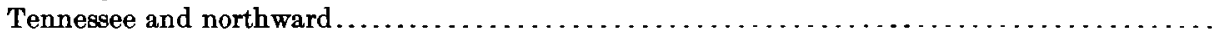

Alabama and Georgia.

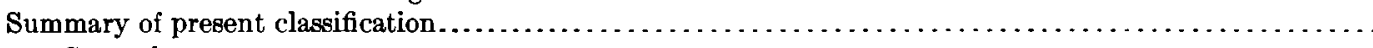

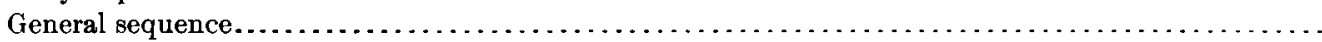

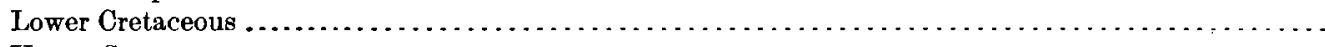

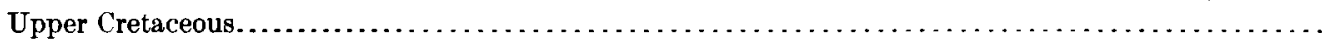

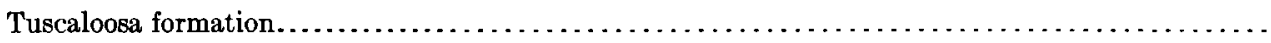

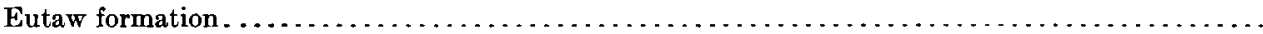

Typical beds. . . . . . .

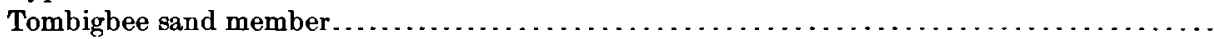

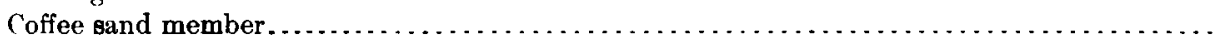

Selma chalk.

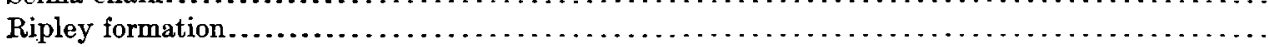

Mississippi, Tennessee, Kentucky, and Illinois . . . . . . . . . . . . . . . . . . .

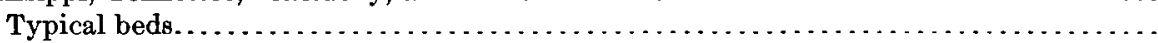

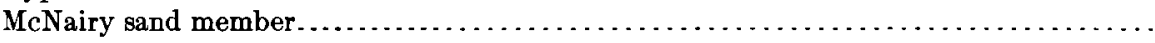

Alabama and Georgia.

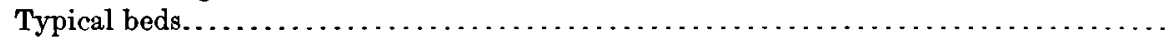

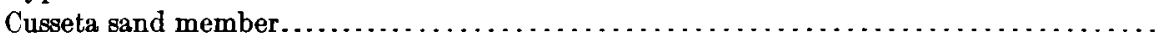

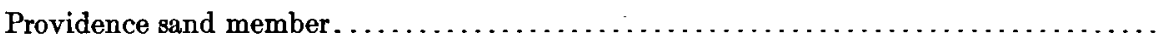

Surficial deposits.

Faunal zones and subzones.

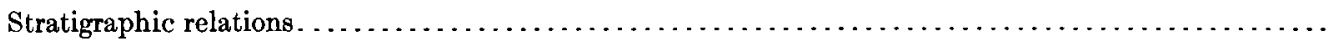

Fossil localities. 
Cretaceous deposits of the eastern Gulf region-Continued.

Faunal zones and subzones-Continued. Page.

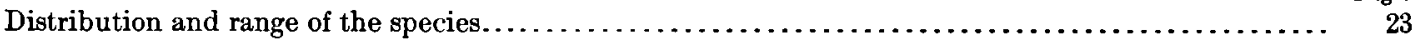

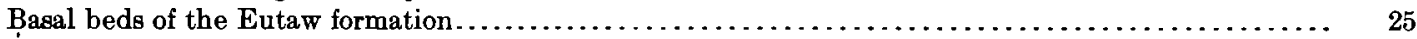

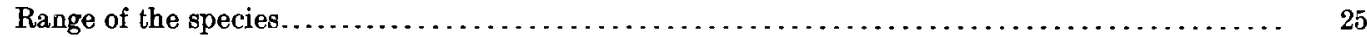

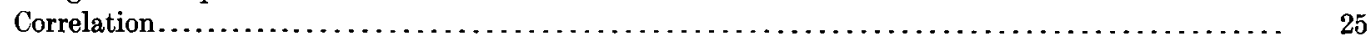

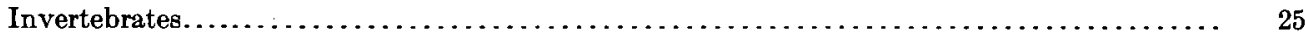

Plants. . . . . . . . . . . .

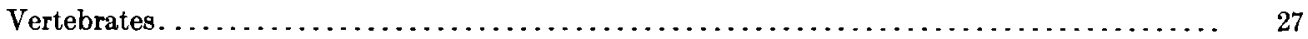

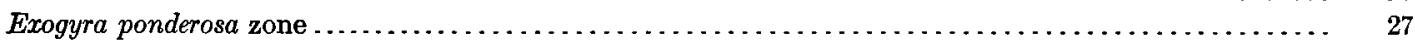

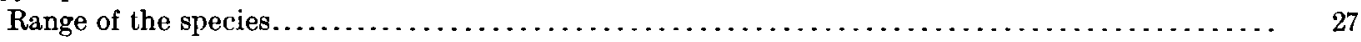

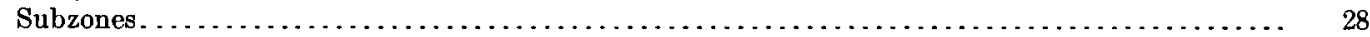

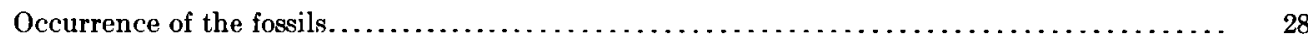

Mortoniceras subzone............................................. 29

Part of Exogyra ponderosa zone between the Mortoniceras subzone and the Exogyra costata zone.. $\quad 30$

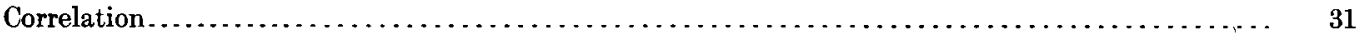

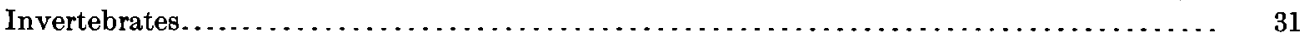

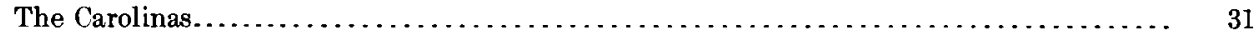

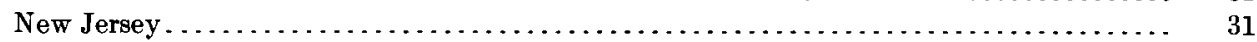

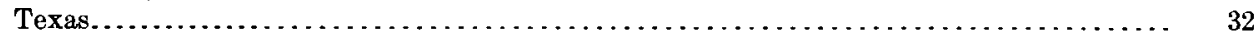

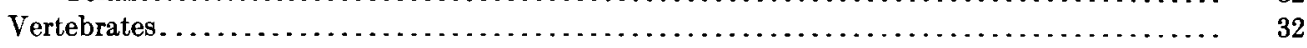

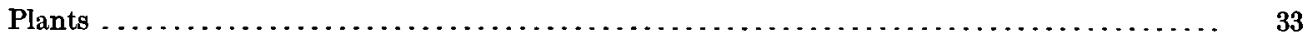

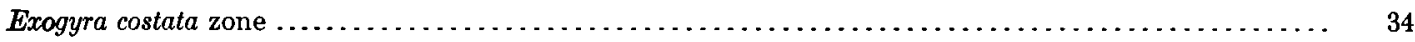

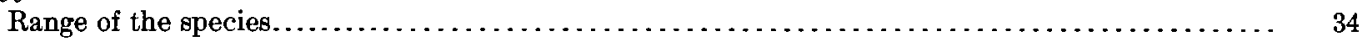

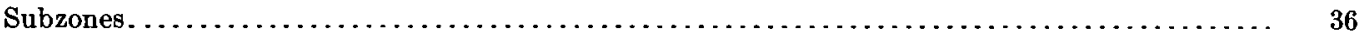

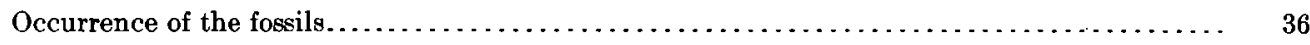

Liopistha protexta subzone................................................ 36

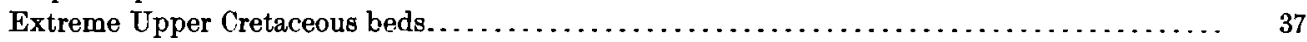

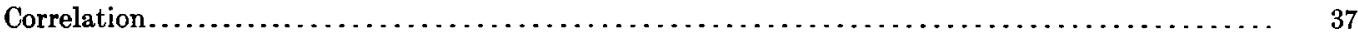

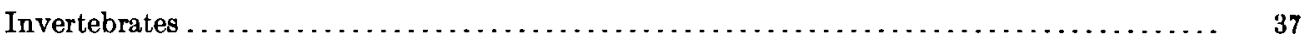

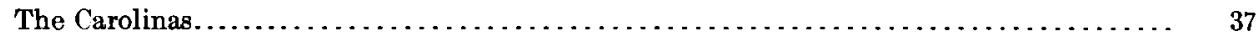

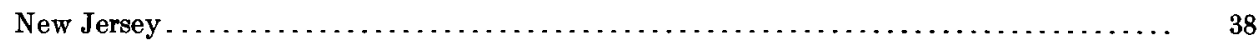

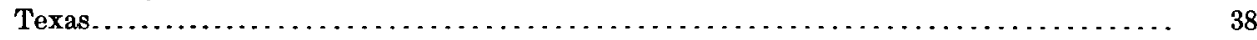

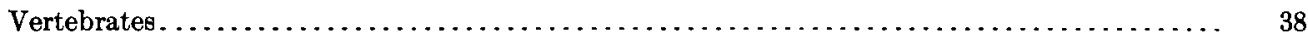

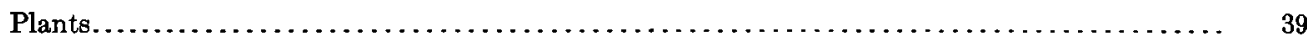

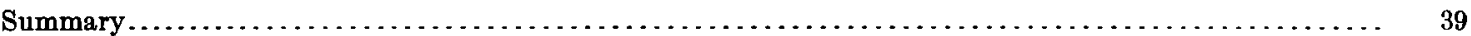

Species and varieties of Exogyra from the eastern Gulf region and the Carolinas....................... 41

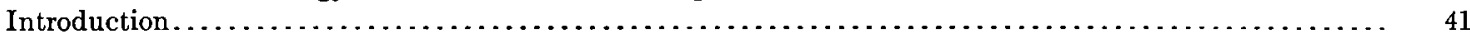

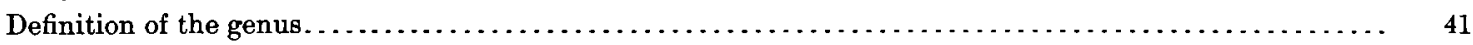

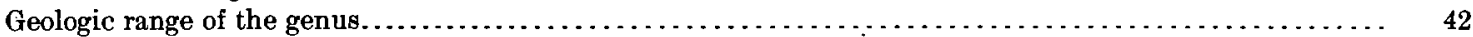

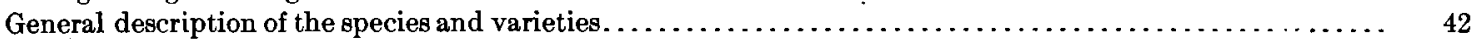

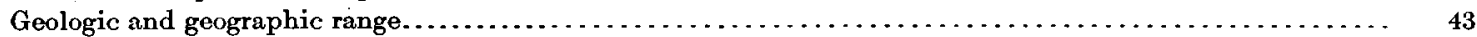

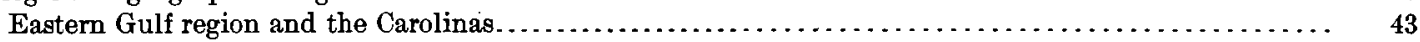

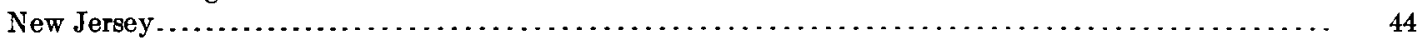

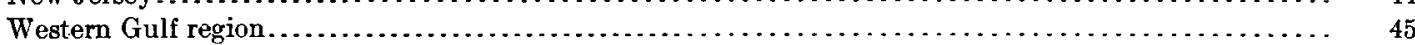

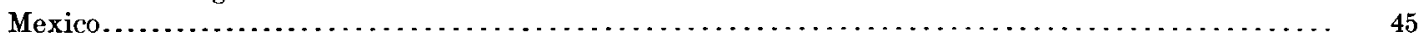

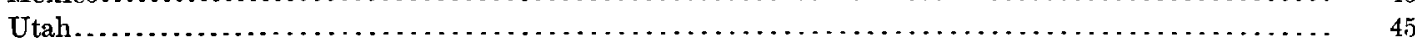

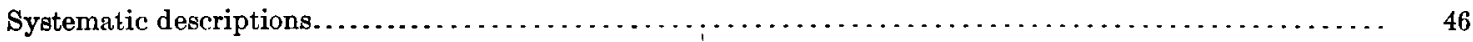

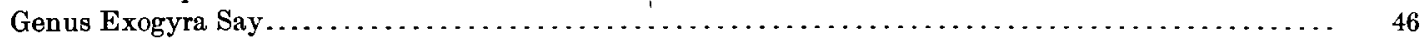

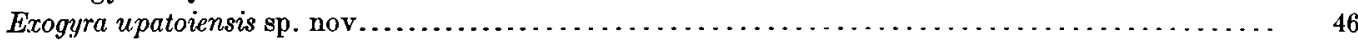

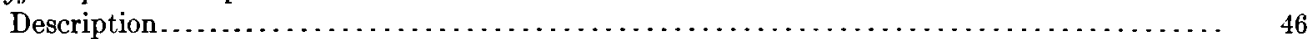

Geologic occurrence.............................................. 46

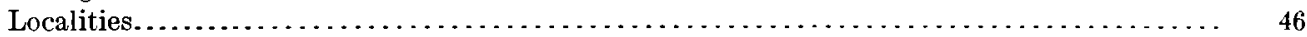

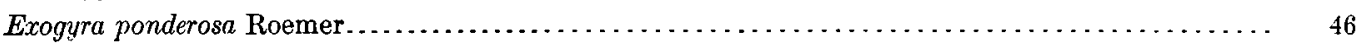

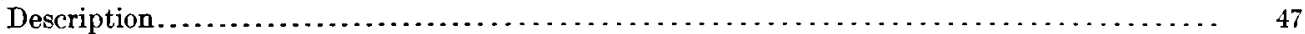

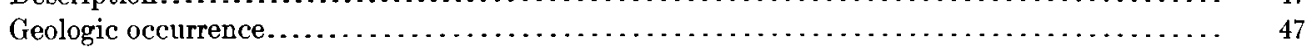

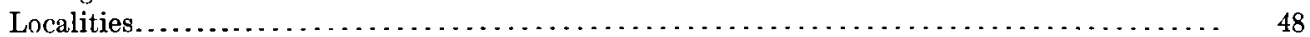

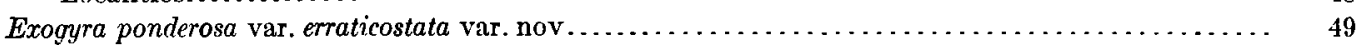

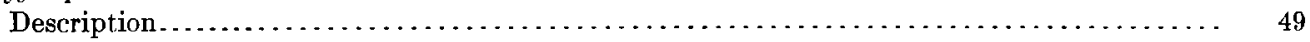

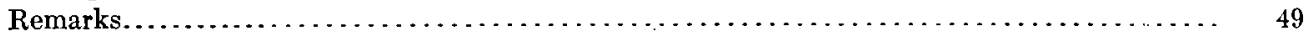

Geologic occurrence............................................... 49

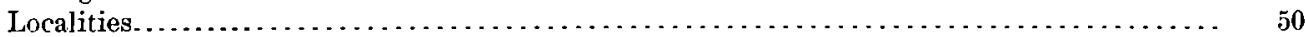


Species and varieties of Exogyra from the eastern Gulf region and the Carolinas-Continued. Systematic descriptions-Continued.

Genus Exogyra Say-Continued.

Exogyra costata Say

Page.

50

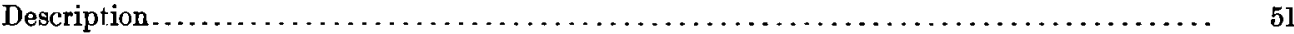

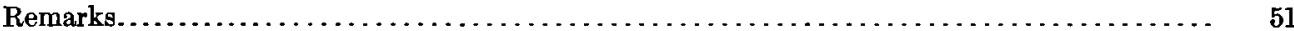

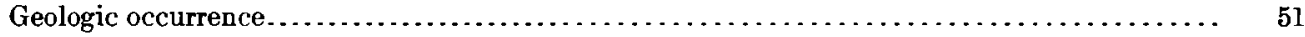

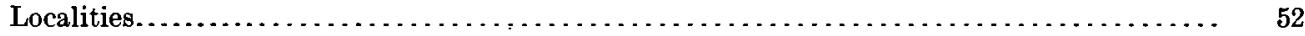

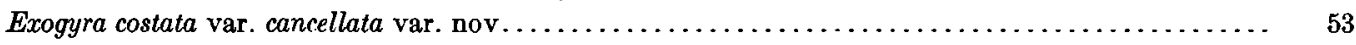

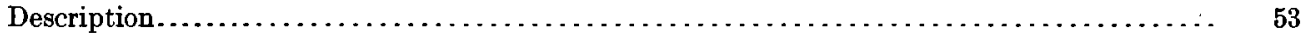

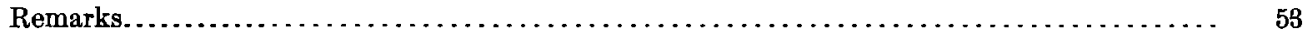

Geologic occurrence.................................................... 54

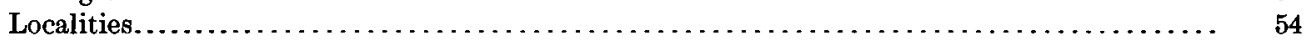

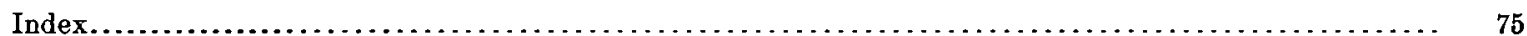

INSERTS.

TABLES 2 to 9 . Range of Cretaceous fossils.

Page 


\section{ILLUSTRATIONS.}

Plate I. A, Lower Cretaceous sands and clays overlain unconformably by Pleistocene terrace gravels, sands, and sandy loams, Coosada Bluff, Alabama River, 11 miles north of Montgomery, Ala.; $B$, Unconformable contact between Lower Cretaceous clay and basal sands of the Eutaw formation, cut in Seale Road, 4 miles southwest of Columbus, Ga., in Russell County, Ala . . . . . . . . . . . . .

II. $A$, Tuscaloosa formation, consisting of sands and clays with interbedded ferruginous layers, Huntsville road, $1 \frac{1}{2}$ miles east of Cottondale, Tuscaloosa County, Ala.; $B$, Laminated sands and clays of the Eutaw formation, bluff at Z. Logan's landing, Warrior River, Hale County, Ala., $8 \frac{1}{2}$ miles (by the river) above the Alabama Great Southern Railroad bridge.

III. A, Typical beds of the Tombigbee sand member of the Eutaw formation, Plymouth Bluff, Tombigbee River, Lowndes County, Miss.; $B$, Laminated sands and clays of Coffee sand member of the Eutaw formation, bluff just above Pittsburg Landing, Hardin County, Tenn.

IV. $A$, Basal marine beds of the Eutaw formation, Broken Arrow Bend, Chattahoochee River, Alahama side, $10 \frac{1}{2}$ miles (by the river) below Columbus, Ga.; $B$, Beds of the Tombigbee sand member of the Eutaw formation as developed in the Chattahoochee region, Banks Landing, Chattahooche River, $26 \frac{1}{2}$ miles (by the river) below Columbus, Ga.

V. $A$, Typical exposure of the Selma chalk, Jones Bluff, Tombigbee River, near Epes, Sumter County, Ala.; $B$, Selma chalk at its type locality, Alabama River, Selma, Ala.

VI. $A$, Classic fossil locality of the Ripley formation, bluff on Owl Creek, 3 miles northeast of Ripley, Tippah County, Miss.; $B$, Beds of the McNairy sand member of the Ripley formation, cut of Southern Railway $1+$ miles west of Cypress, McNairy County, Tenn.....................

VII. $A$, Marine beds of the Ripley formation, Chattahoochee River, Eufaula, Ala.; B, Marine beds of the Ripley formation, cut of Louisville \& Nashville Railroad 13 miles north of Fort Deposit, Lowndes County, Ala...

VIII. $A$, Cusseta sand member of the Ripley formation overlain by typical marine beds of the formation, cut of Seaboard Air Line Railway at Hichitee (Manta station), Chattahoochee County, Ga.; B, Beds

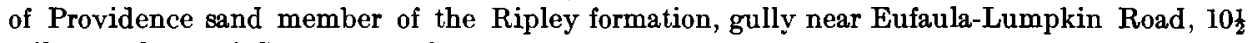

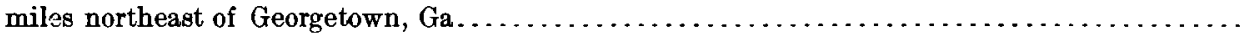

IX. Geologic map of Cretaceous deposits of the eastern Gulf region .............................. In pocket.

$X$. Diagram showing the lithologic variations and age relationships of the Cretaceous deposits of the eastern Gulf region and their correlation with the Carolina and North Atlantic Cretaceous.........

XI. Specimens of Exogyra and other fossils weathered from Selma chalk: A, "Bald Knob," 3 miles west of Corinth, Alcorn County, Miss. ; $B$, One mile west of Cotton Gin Port, Monroe County, Miss. .

XII. Diagram showing the ranges in the Atlantic and Gulf Coastal Plain of the species and varieties of

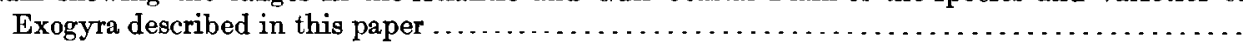

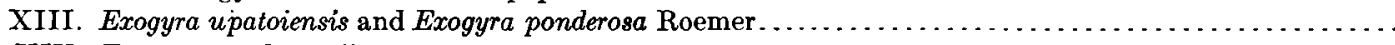

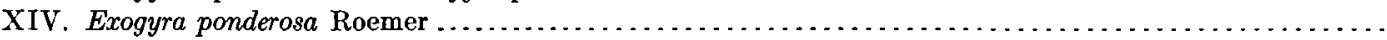

XV. Exogyra ponderosa Roemer and Exogyra ponderosa var. erraticostata var. nov . . . . . . . . . . . . . . .

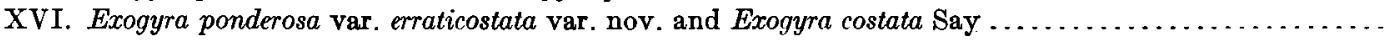

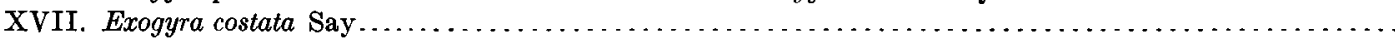

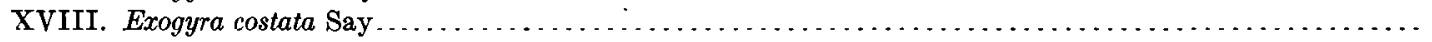

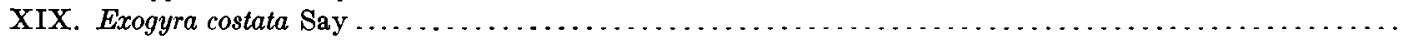

XX. Exogyra costata Say and Exogyra costata var. cancellata var. nov . . . . . . . . . . . . . . . . . . .

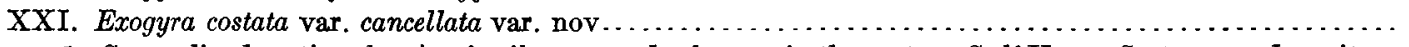

FIGURE 1. Generalized section showing fossil zones and subzones in the eastern Gulf Upper Cretaceous deposits.

2. Sketch map showing areas of paleontologic collections listed in Tables 1 to 8

Page. 


\section{PREFACE.}

The investigations furnishing the materials for the two papers included in this volume have been carried on by the United States Geological Survey in cooperation with the State geologicaI surveys of South Carolina, Georgia, Alabama, and Mississippi, under the direction of T. Wayland Vaughan, of the United States Geological Survey.

The correlations with deposits in North Carolina are based on work carried on in that State by the writer from 1905 to 1909 , under the auspices of the United States Geological Survey, in cooperation with the North Carolina Geological Survey, and under the immediate direction, during part of the time, of M. I. Fuller, of the United States Geological Survey, and during the remainder under that of Prof. William Bullock Clark, of Johns Hopkins University. In accordance with an agreement with the authorities of the Federal Survey the results of the North Carolina investigations were used in the preparation of a dissertation offered in fulfillment of one of the requirements for the degree of doctor of philosophy at Johns Hopkins University.

Numerous exhaustive collections made in 1889 and 1891 by T. W. Stanton, of the United States Geological Survey, from localities in the Atlantic and Gulf Coastal Plain and additional smaller collections in the National Museum made by other investigators have been placed at the disposal of the writer. The fossils collected by Mr. Stanton in Mississippi were determined and listed by him shortly after his return from the field in 1889, and these lists with the accompanying notes have also been placed at the disposal of the writer. For the assistance thus rendered and for many valuable suggestions and criticisms especial thanks are due to $\mathrm{Mr}$. Stanton.

The names of the echinoderm species included in the lists have been furnished by Prof. William Bullock Clark, to whom the specimens were sent for identification. Some of the fish remains mentioned in the text have been identified by Mr. J. W. Gidley, of the National Museum, and all the reptilian remains have been identified by $\mathrm{Mr}$. C. W. Gilmore, also of the National Museum. Indebtedness is acknowledged to these gentlemen for their cooperation.

During the progress of the investigations the writer has been associated both in the field and in numerous conferences with Mr. E. W. Berry, of Johns Hopkins University, who has been engaged in a study of the fossil plant remains from the Cretaceaus beds. Indebtedness is acknowledged to Mr. Berry for numerous annotated lists of plant species and for the many benefits resulting from close association with an investigator of his ability.

The writer has also been associated in the field and in conference with Dr. Eugene A. Smith, State geologist of Alabama, and with Mr. Earle Sloan, State geologist of South Carolina, who have spared neither time nor effort in assisting in the solution of stratigraphic problems in their respective States. He has also been associated with $\mathrm{Mr}$. Otto Veatch, assistant State geologist of the Georgia Geological Survey, to whom thanks are due for much valuable assistance and also for field notes placed at the writer's disposal.

The publications of many authors have also been freely drawn upon for information and for field guidance.

In comparing the Cretaceous faunas of the South with those of New Jersey the writer has reiled for his statements as to the range of New Jersey species on the excellent monograph by Stuart Weller, published in 1907 by the Geological Survey of New Jersey, entitled "A report on the Cretaceous paleontology of New Jersey."

As the investigations progressed the value of the representatives of the genus Exogyra in establishing the major faunal divisions into which the marine Upper (retaceous deposits of the eastern Gulf region are divisible, and in correlating these divisions with Upper Cretaceous deposits elsewhere in the Atlantic and Gulf Coastal Plain, became more and more apparent. It has seemed appropriate, therefore, to describe the species and varieties of the genus and to note their distribution and range. 



\title{
CRETACEOUS DEPOSTTS OF THE EASTERN GULF REGION.
}

\author{
By Lloyd William Sthphenson. \\ OBJECT AND SCOPE OF THE WORK.
}

This paper is intended as a brief statement of the results of stratigraphic and paleontologic investigations made by the writer during recent years in the Cretaceous areas of the eastern Gulf region. The principal objects in view were to determine the lithologic units worthy of recognition as formations or as members, the lithologic and paleontologic characters of these units, and their stratigraphic and age relations. Although the results of the work have not been in all respects as satisfactory as might have been desired, yet it is believed that the purposes outlined have in large measure been accomplished.

The major lithologic divisions present in the region have all been recognized more or less clearly by previous investigators, and no sweeping changes in the generally accepted nomencluture of the deposits have been fuund necessary. But one new name (McNairy sand member of the Ripley formation) is proposed and this is given the rank of member; two old formational names which have, during recent years, fallen into disuse, have recently been revived by the writer ${ }^{1}$ with the rank of members; and certain basal Cretaceous deposits in eastern Alabama and in Georgia, previously regarded as the eastward continuation of the Tuscaloosa formation, are shown with reasonable certainty to be of Jower Cretaceous age and therefore probably sepurated from the Tuscaloosa formation by an unconformity. However, more definite knowledge has been gained of the character and the geologic and geographic boundaries of the several units recognized.

The chief additions to the knowledge of the region have been those furnished by a critical study of the organic remains entombed in the deposits; for by this means much light has been thrown or the age relations of the several lithologic units. On pages $23-40$ it is shown that the usual methods of mapping formational units fail properly to express true age relations when applied to the deposits of this region, and that to show these relations it is necessary to employ additional superimposed symbols. In places (see Pl. IX, in pocket) the boundaries of lithologic units run obliquely to the general direction of the strike of the strata composing the Upper Cretaceous formations of the region with absolute disregard to the boundaries of paleontologic zones and subzones. Although records of such phenomena are not uncommon in the literature, the relative abruptness with which some of the lithologic units here treated merge horizontally into others of different character furnishes unusually striking examples of this sort of formational relationship.

The deposits considered are in part of Lower Cretaceous and in part of Upper Cretaceous age. Their area of surface occurrence embraces a belt of country extending from southern Illinois, where it is only a few miles wide, southward with gradually increasing width through Kentucky and Tennessee to Mississippi and western Alabama, where it reaches a maximum width of 80 miles; thence sweeping around to the east in a broad curve through Alabama, and with gradually decreasing width extending northeastward. into Georgia. The lower representatives of the series continue northeastward in a narrow 'belt of surface outcrops through Georgia and South Carolina, eventually connecting with similar deposits in North Carolina; the higher representatives also extend northeastward in Georgia, but they pass beneath over-

1 Stephenson, L. W., Cretaceous [Georgia]: Bull. Georgia Geol. Survey No. 26, 1911, Pl. V, pp. 111-112. 
lapping Eocene beds and do not reappear at the surface until they reach the valley of Peedee River in eastern South Carolina, in which region, and also to the northeastward in North Carolina, exposures are common along the streams.

\section{PAST AND PRESENT INTERPRETATIONS.}

LOWER CRETACEOUS.

The basal portion of the rocks of the Coastal Plain in the region included between the Alabama Valley in Alabama and the Roanoke Valley in North Carolina is composed of highly crossbedded arkosic sands, in general of coarse texture, with subordinate interbedded layers and lenses of light-colored clays of greater or lesser purity, reaching an estimated maximum thickness of 500 to 600 feet. These have been regarded as the eastward continuation of the Tuscaloosa formation by the Alabama and Georgia geologists." They have been designated the "Hamburg beds" by Sloan ${ }^{2}$ in South Carolina and the "Cape Fear" formation by the writer ${ }^{3}$ in North Carolina. These beds are separated by unconformities from the overlying Black Creek formation in the Carolinas and from the overlying Eutaw formation in the Chattahoochee and Alabama river regions in Georgia and Alabama. (See Pl. I, B.)

In 1906 the exposures of these beds on Chattahoochee River below Columbus, Ga., were examined by the writer, and during subsequent years numerous localities in Alabama and Georgia were visited by him. Various considerations, based on physical evidence, led him to conclude that the terrane is older than the Tuscaloosa formation, that it probably corresponds to the "Hamburg beds" of South Carolina and to the "Cape Fear" formation of North Carolina, and that it is probably of Lower Cretaceous age. E. W. Berry, who later visited a number of the localities in company with the writer, concurred in these views.

The first and strongest argument in favor of this interpretation was the existence of a distinct unconformity separating these beds from the overlying Eutaw formation. This was noted unmistakably at McBride Ford on Upatoi Creek, Chattahoochee County, Ga.; at the Lumpkin road bridge over Upatoi Creek a few miles above its mouth; on Chattahoochee River just below the mouth of Upatoi Creek and at Broken Arrow Bend, 9 miles below Columbus, Ga.; on the Seale road 4 miles southwest of Columbus in Russell County, Ala. (PI. I, B); and on Alabama River 5 miles above Montgomery, Ala. The unconformity was also questionably noted at several places intermediate between those named. No such unconformity is known to exist between the true Tuscaloosa formation and the overlying Eutaw formation in central or western Alabama or in Mississippi.

The beds differ from the true Tuscaloosa deposits in the following respects: The sands contain a large percentage of white kaolin grains, which render them arkosic; the layers and lenses of clay are massive, being thus in contrast with the laminated beds so common in the Tuscaloosa (Pl. I, $A$ ); and the beds lack identifiable fossil plant remains except at one locality. On the other hand, in all these characters they strongly resemble the "Hamburg beds" of South Carolina and the "Cape Fear beds" of North Carolina, and it was this fact, together with their apparent continuity with the deposits of the Carolinas, that led to the belief that they are synchronous with those deposits.

The "Cape Fear" formation is separated geographically from the Cretaceous deposits to the north in Virginia by an overlap of Miocene beds. However, in all their physical characters the "Cape Fear" materials bear a close resemblance to the Patuxent formation, which forms the basal division of the Potomac group in Virginia and Maryland. On account of this physical similarity and because of their supposed buried connection with the Virginia Patuxent, the application of the name Patuxent has been extended to include these arkosic beds ${ }^{4}$ in North

1 Langdon, D. W., Variations in Cretaceous and Tertiary strata of Alabama: Bull. Geol. Soc. America, vol. 2, 1890, pp. 587-606. Veatch, Otto, Second report on the clays of Georgia: Bull. Georgia Geol. Survey No. 18, 1909, pp. 82-106.

' Sloan, Earle, Clays of South Carolina: Bull. South Carolina Geol. Survey, 4th ser., No. 1, 1904, pp. 72-75; Handbook of South Carolina, State Dept. Agr., Com., and Imm., 1907, pp. 85-88.

s Stephenson, I. W., Some facts relating to the Mesozoic deposits of the Coastal Plain of North Carolina: Johns Hopkins Univ. Circ., new ser., No. 7, July, 1907, pp. 93-99.

- Stephenson, L. W., The Cretaceous formations [North Carolina]: North Carolina Geol. and Econ. Survey, vol. 3, 1912, pp. 83-1I1. 


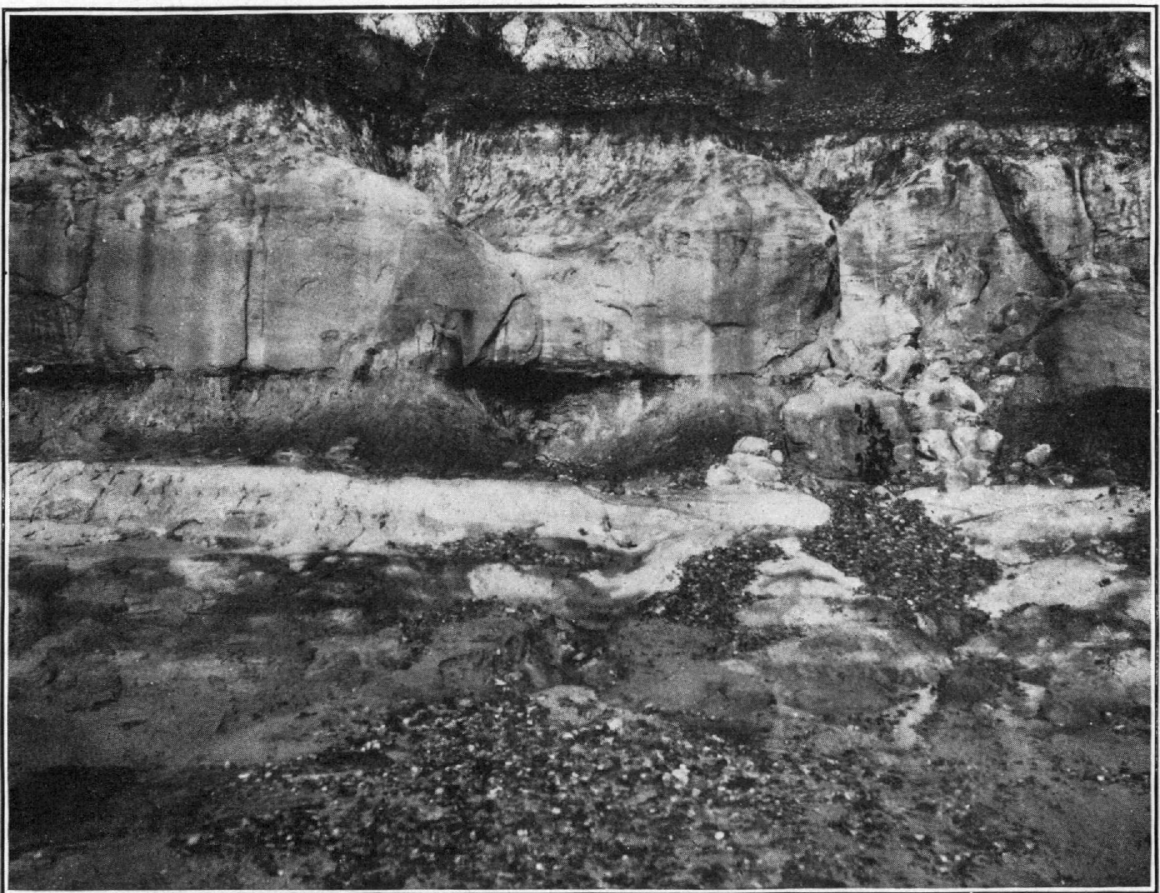

A. LOWER CRETACEOUS SANDS AND CLAYS OVERLAIN UNCONFORMABLY BY PLEISTOCENE TERRACE GRAVELS, SANDS, AND SANDY LOAMS, COOSADA BLUFF, ALABAMA RIVER, 11 MILES NORTH OF MONTGOMERY, ALA.

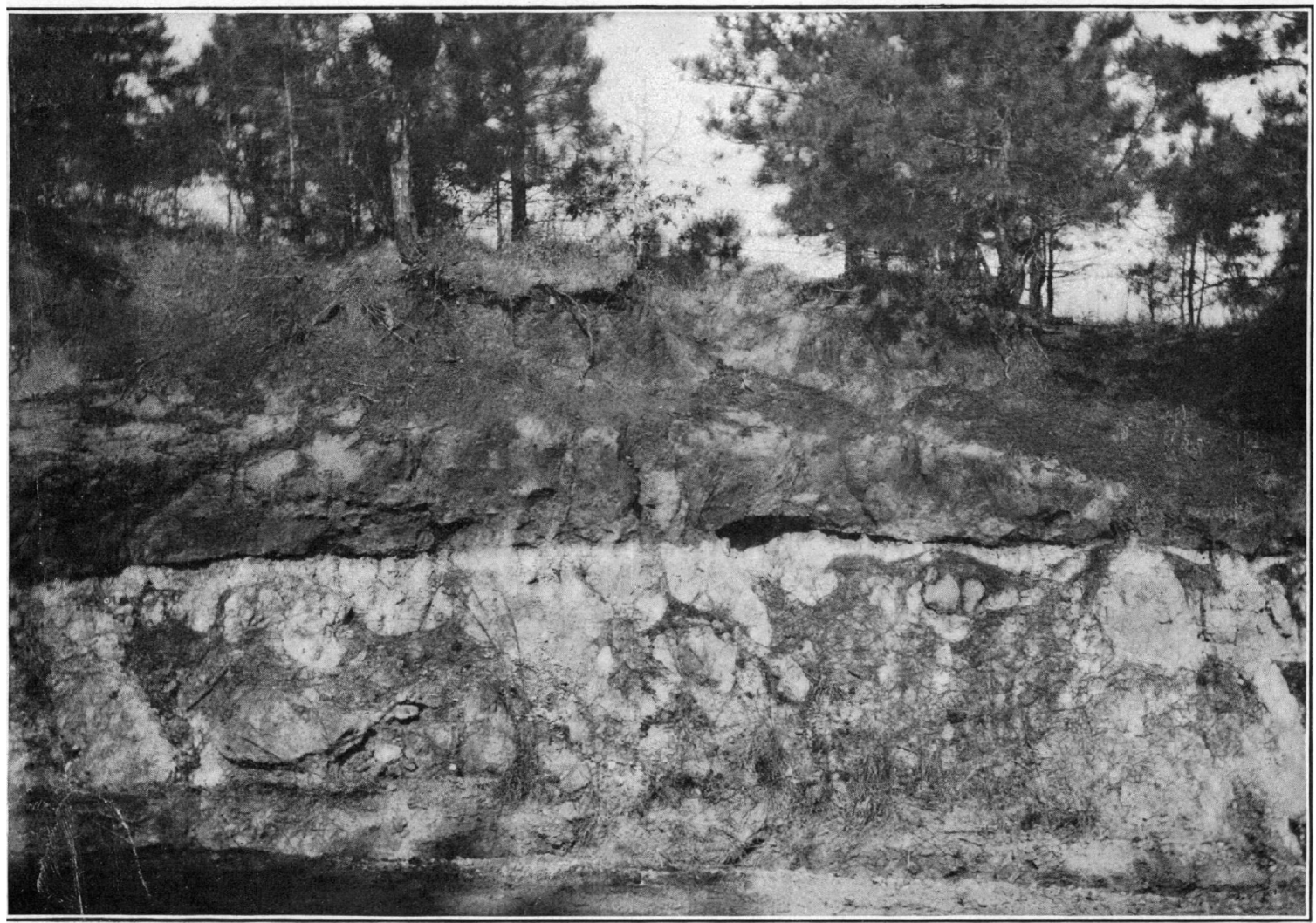

B. UNCONFORMABLE CONTACT BETWEEN LOWER CRETACEOUS CLAY AND BASAL SANDS OF THE EUTAW FORMATION, CUT IN SEALE ROAD, 4 MILES SOUTHWEST OF COLUMBUS, GA., IN RUSSELL COUNTY, ALA. 

Carolina. In the absence of evidence to the contrary it would seem proper to extend the application of the name still farther south to include the apparently continuous deposits in South Carolina, Georgia, and Alabama.

Until recently no organic remains had been found in the beds under discussion south of the Virginia line, but in the fall of 1910 the writer discovered a few poorly preserved plant remains in beds exposed in a bluff on Tallapoosa River at Old Fort Decatur, in Macon County, Ala. These have been submitted to E. W. Berry, who expresses the opinion that the beds containing them are of Lower Cretaceous age. One poorly preserved cast of a Unio was found associated with the plant remains.

The previous conclusions regarding the age of the beds below the Eutaw formation seem thus to be confirmed by the paleontologic evidence. Unfortunately the poorly preserved condition of the leaves renders it difficult to determine satisfactorily the relation of the formation to the Patuxent formation of Virginia and Maryland. However, in Berry's opinion, the presence of large numbers of leaves, apparently dicotyledons, most of which are too poorly preserved to permit specific or even generic determination, seems to justify doubt as to their being as old as the Patuxent, in which similar questionably identified dicotyledons are very sparingly represented.

The following statement concerning the fossil remains of the Patuxent formation is quoted from a paper by Clark and Bibbins: ${ }^{1}$

The flora of the Patuxent formation includes Equiseta, ferns, cycads, conifers, monocotyledons, and a very few archaic dicotyledons, the coniferous and cycadean element being particularly strong. The known fauna of the Patuxent formation is limited to a single Unio (Ward) and a fish (Fontaine).

Should future discoveries confirm the doubt expressed by Berry as to the Patuxent age of the Lower Cretaceous beds of Alabama and Georgia, and should it be found that the AlabamaGeorgia Lower Cretaceous deposits are synchronous with the "Cape Fear" formation, it would at once become apparent that the name Patuxent was not appropriate for Lower Cretaceous deposits anywhere south of Virginia.

Although the "Cape Fear beds" appear to be continuous with the Lower Cretaceous arkosic seds of South Carolina, Georgia, and Alabama, it is possible that they are not actually continuous; for the irregular character of the bedding, the presence of numerous local unconformies within the beds, and the lack of extensive exposures render the detection of an important nconformity difficult-and such an unconformity may exist.

A hypothesis which was suggested to the writer by T. W. Vaughan and which is worthy of c nsideration is that the arkosic beds extending from Maryland southward to Alabama were I I down along a coast margin which was being gradually and continuously depressed from the $\mathrm{n}$ th to the south. In this case the deposits might actually be continuous and yet contain fi il plants at the south end of the belt of outcrop younger than those at the north end.

UPPER CRETACEOUS.

EARLY CORRELATIONS.

Morton's correlation.-The presence in the eastern Gulf region of the so-called "Ferruginous sand formation" was first noted by Morton ${ }^{2}$ in 1829, the beds thus designated being correlated with the "Ferruginous sand formation" of New Jersey and with the Chalk of Europe, especially vith the Ferruginous sand of the English geologists and with the Lower Chalk of the French geologists. The term Cretaceous, which later supplanted the terms "Chaik" and "Ferru inous sand," was first applied to the American deposits by Morton ${ }^{3}$ in 1833.

\footnotetext{
1 Clark: B., and Bibbins, Arthur, Geology of the Potomac group in the middle A tlantic slope: Bull. Geol. Soc. America, vol. 13, 1902, p. 192.

${ }^{2}$ Mortc. B., Description of two new species of fossil shells of the genera. Scaphites and Crepidula, with some observations on the ferruginous sand, plast. $\quad$ iy, and upper marine formations of the United States: Jour. Acad. Nat. Sci., vol. 6, 1892, pp. 107-129 (especially p. 127).

${ }^{3}$ Morte 5. G., Synopsis of the organic remains of the Ferruginous sand formation of the United States: Am. Jour. Sci., 1st ser., vol. 24, 1833,

pp. 128-132.
} 
Tuomey's classification.-In 1850 Tuomey ${ }^{1}$ described and mapped the Cretaceous deposits of Alabama. Two divisions, the Lower and Upper Cretaceous, were recognized. The former corresponded roughly to the Eutaw formation of the present report, and the latter included the Selma chalk and Ripley formation and, erroneously, a portion of the overlying Eocene strata. That part of the Cretaceous now included in the Tuscaloosa formation was erroneously referred to the Tertiary.

Winchell's classification.-In 1857 Winchell $^{2}$ subdivided the Cretaceous of Alabama in descending order as follows: Prairie Bluff limestone; white sand; Rotten limestone; concrete sand; loose sand; sand and clay.

The "sand and clay," the "loose sand," and the "concrete sand" form parts of the Eutaw formation of this raport; the "Rotten limestone" is synonymous with the Selma chalk; the "white sand" includes the glauconitic sands forming the basal portion of Prairie Bluff on Alabama River, Wilcox County, Ala.; the "Prairie Bluff limestone" includes the few feet of chalk rock forming the uppermost beds of the Cretaceous at Prairie Bluff. This corresponds to the long, narrow tongue of Selma chalk extending through Marengo and Wilcox counties above a westward-extending tongue of the Ripley formation. (See Pl. IX, in pocket.)

Hilgard's classification.-The first classification of the deposits of the eastern Gulf Coastal Plain, in which the whole series of Upper Cretaceous beds was definitely assigned to that epoch, was that of Hilgard, ${ }^{3}$ State geologist of Mississippi. He differentiated four major divisions in the Cretaceous deposits of that State, in descending order, as follows: Ripley group, Rotten limestone group, Tombigbee sand group, and Eutaw group.

Smith and Johnson's classification.-In 1887, Eugene A. Smith, State geologist of Alabama, and Lawrence C. Johnson ${ }^{4}$ published a classification of the Cretaceous deposits of Alabama, the divisions recognized being as follows: Ripley formation, Rotten limestone, Eutaw formation, and Tuscaloosa formation.

\section{TUSCALOOSA AND EUTAW FORMATIONS.}

East-central Mississippi.-According to Hilgard the Eutaw rests upon Carboniferous rocks and includes all the Cretaceous deposits below the Tombigbee sand. He says that it consists of "bluish black or reddish laminated clays, often lignitic, alternating with and usually overlain by noneffervescent sands, mostly (though not always) poor in mica and of a gray or yellow tint. Contains beds of lignite, very rarely other fossils." 5

He adds: "I adopt this name (Eutaw group) in view of these beds having been first examined in detail and recognized as being of Cretaceous age by Tuomey, ${ }^{6}$ near Eutaw, Ala., where they are characteristically developed."

The Tombigbee sand, as described by Hilgard, consists of-

A fine-grained micaceous sand, more or less calcareous, usually of a greenish tint but not infrequently gray, bluish black, yellowish, and sometimes even orange-red. Clays and noncalcareous (as also at times nonmicaceous) sands are also found, although generally they are only subordinate to the characteristic greenish sand, which is the exclusive material in the southerly region of development, in South Monroe and Lowndes.

The type region of the Tombigbee sand is in the vicinity of Columbus, in Lowndes County, Miss., where it is mapped as a belt 15 or 18 miles wide. The type exposures occur in bluffs of Tombigbee River in this county. (See Pl. III, A.) North of Lowndes County the Tombigbee belt is represented as narrowing to a strip 2 to 4 miles wide, with a corresponding widening of the Eutaw area. By thus narrowing the Tombigbee belt what Hilgard actually did was to run his Eutaw-Tombigbee boundary line obliquely across the strike of the beds; north of this line he represents strata as belonging to the Eutaw which correspond in age and stratigraphic

1 Tuomey, M., First biennial report on the geology of Alabama, 1850, pp. 116-142.

2 Winchell, Alexander, Notes on the geology of middle and southern Alabama: Proc. Am. Assoc. Adv. Sci., vol. 10, pt. 2, 1857, pp. 90-93.

s Hilgard, E. W., Report on the geology and agriculture of the State of Mississippi, 1860, pp. 60-95.

4 Tertiary and Cretaceous strata of the Tuscaloosa, Tombigbee, and Alabama rivers: Bull. U. S. Geol. Survey No. 43, 1887 , pp. 71-138.

5 Hilgard, E. W., op. cit., p. 61 .

- Tuomey's account of the beds near Eutaw to which reference is made is recorded in the First biennial report on the geology of Alabama, 1850, pp. 118-120. Tuomey recognized the Cretaceous age of these beds but did not propose a formational name for them. 


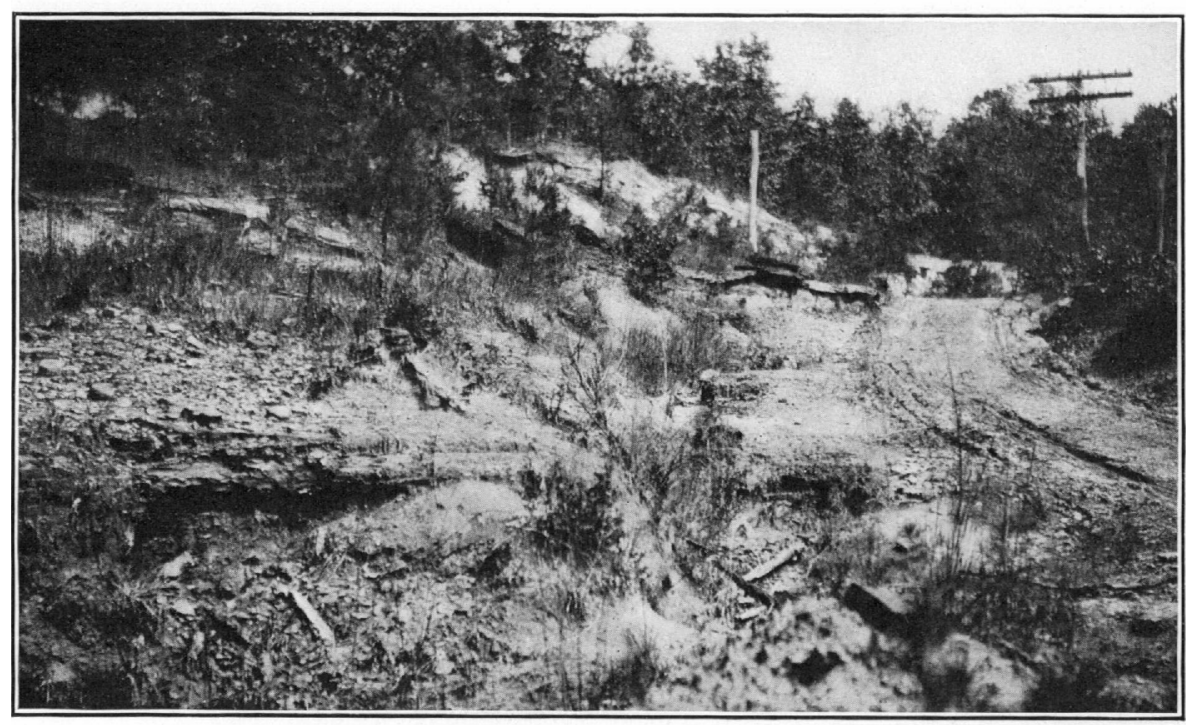

A. TUSCALOOSA FORMATION, CONSISTING OF SANDS AND CLAYS WITH INTERBEDDED FERRUGINOUS LAYERS, HUNTSVILLE ROAD, $1 \%$ MILES EAST OF COTTONDALE, TUSCALOOSA COUNTY, ALA.

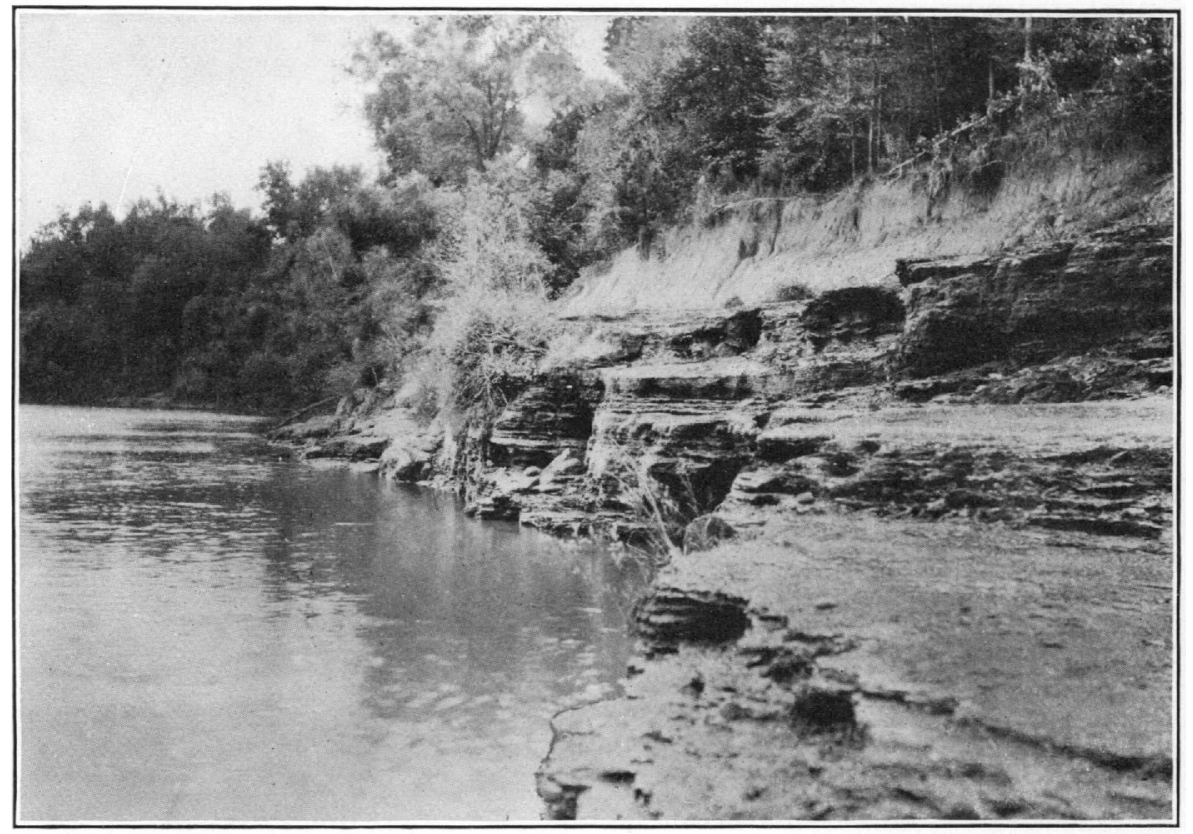

B. LAMINATED SANDS AND CLAYS OF THE EUTAW FORMATION, BLUFF AT z. LOGAN'S LANDING, WARRIOR RIVER, HALE COUNTY, ALA., 81/3 MILES (BY THE RIVER) ABOVE THE ALABAMA GREAT SOUTHERN RAILROAD BRIDGE. 


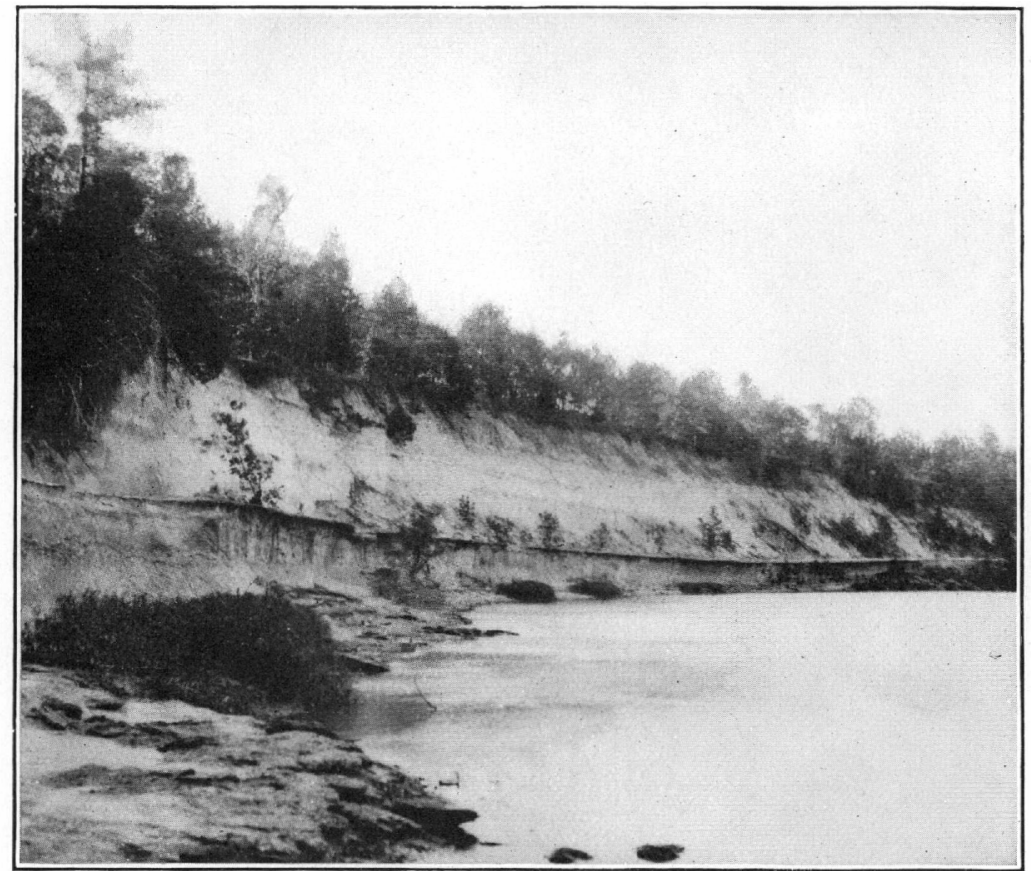

A. TYPICAL BEDS OF the tOMBIgBeE SAND MEMBER OF the EUTAW FORMATION, PLYMOUTH BLUFF, TOMBIGBEE RIVER, LOWNDES COUNTY, MISS.

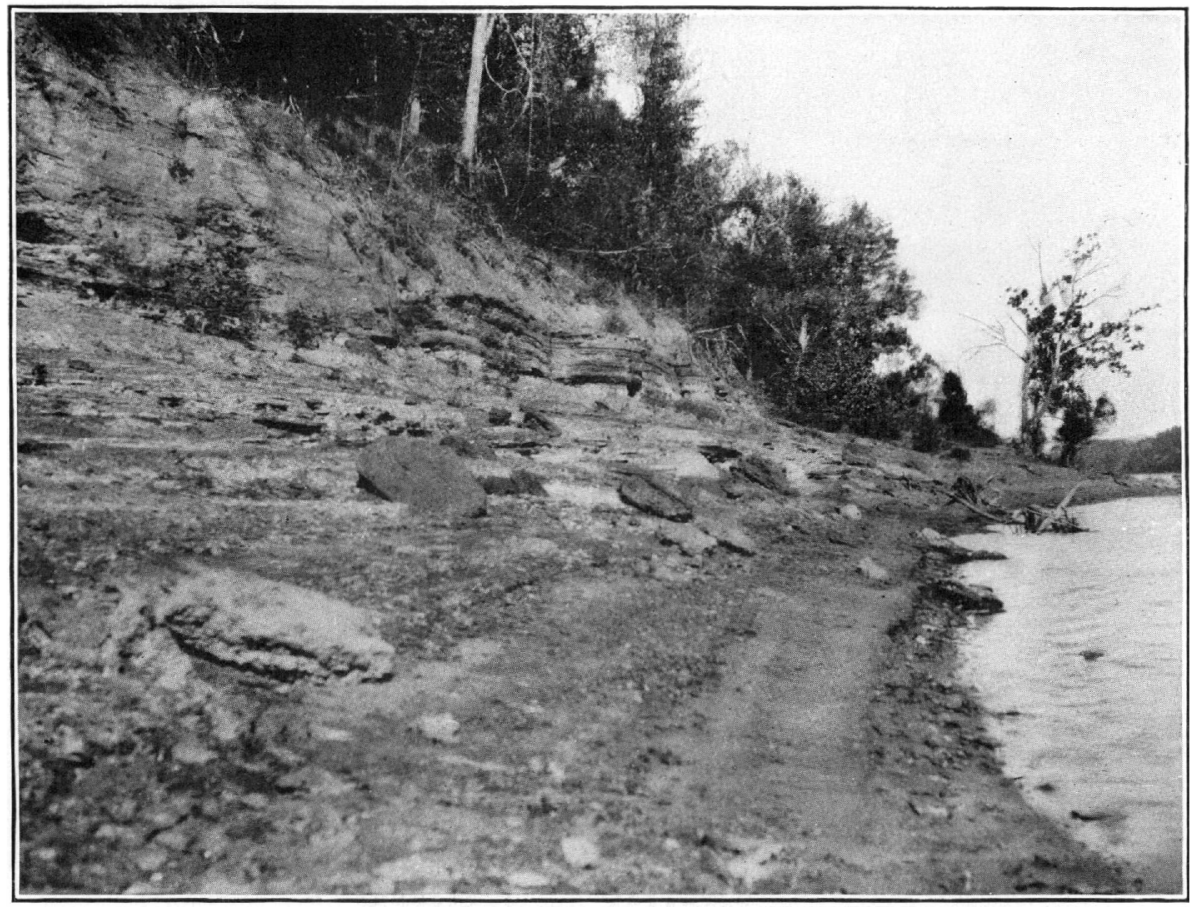

B. LAMINATED SANDS AND CLAYS OF COFFEE SAND MEMBER OF THE EUTAW FORMATION, BLUFF JUST ABOVE PITTSBURG LANDING, HARDIN COUNTY, TENN. 
position to the lower two-thirds or threc-fourths of the Tombigbee as mapped south of the line; indeed the sections given as typical of the Eutaw lie within these northward Tombigbee representatives.

Western Alabama.-The Eutaw group of Hilgard in Mississippi represents all of the Tuscaloosa formation and a part of the Eutaw formation as subsequently defined by Smith and Johnson in Alabama. They described the Tuscaloosa formation as consisting of at least 1,000 feet of "purple and mottled clays interstratified with white, yellowish-white, pink, and light purple micaceous sands, and near the base of the formation dark-gray, nearly black, thinly laminated clays with sand partings."

The Eutaw formation is described as "a series of laminated sands and sandy clays at least 300 feet in thickness."

If only those parts of the area in Mississippi immediately west of the Alabama line, mapped by Hilgard respectively as Eutaw and Tombigbee, are considered, his Eutaw corresponds almost exactly to the Tuscaloosa formation of Smith and Johnson, and the Eutaw of those authors corresponds to the Tombigbee sand of Hilgard. However, the sections of the Eutaw described by Hilgard, all of which are north of Columbus in Mississippi, do not correspond to the Tuscaloosa formation, but, as previously stated, represent a part of the northward extension of the Tombigbee as mapped, and hence actually correspond in stratigraphic position to a part of the Eutaw of Smith and Johnson.

The essential differences between the Tuscaloosa and Eutaw of Smith and Johnson may perhaps best be stated as follows: The Tuscaloosa consists of a succession of sands, clays, and gravels of probable estuarine and shallow-water origin, characterized by irregularity of bedding, and, where the conditions for their preservation were favorable, by the presence of fossil leaves (Pl. II, $A$ ); the Eutaw consists predominantly of glauconitic sands of marine origin, which in approximately the lower two-thirds or three-fourths of their thickness contain subordinate lenses of dark clay and exhibit lamination and fine cross-bedding (Pl. II, $B$ ), and in the upper one-third or one-fourth are made up of massive beds of glauconitic sand, with calcareous sand beds in the extreme upper part (Pl. III, $A$ ). So far as known no structural break exists between the Tuscaloosa and Eutaw formations, sedimentation apparently having been continuous from the one to the other. Nor has it been possible to recognize any sharp lithologic line of separation between them, the change from the one kind of sedimentation to the other having been transitional.

The Mississippi representatives of the Eutaw formation of Smith and Johnson include, as previously stated, all of the Tombigbee sand and a part of the Eutaw group of Hilgard. Although the width of the Tombigbee belt as mapped by Hilgard immediately west of the Alabama line is 15 to 18 miles, corresponding to a thickness of 400 or 500 feet, the actual sections given by him in this part of the area are all near the western border of the belt and probably include only about the upper 150 or 200 feet of the strata mapped. Farther north in Mississippi beds which correspond in stratigraphic position to the lower two-thirds or three-fourths of the Tombigbee as mapped in Lowndes County are included by Hilgard in his Eutaw group, and among these are the sections which he indicated as typical of this division in Mississippi. These beds correspond in age and position to a part of the Eutaw of Smith and Johnson, although in the intervening area in Lowndes County beds of the same age were mapped as Tombigbee. This confusion was due apparently to the fact that Hilgard failed to find in Lowndes County any of the beds of dark clay corresponding in position to those farther north, on the basis of which he seems to have differentiaterl his Eutaw group. These clays are of a resistant character, and where they occur in stream bluffs form rather conspicuous exposures; but when the division as a whole is considered they constitute only subordinate lenses of clay in deposits made up in the main of glauconitic sands. Such clay beds, however, occur in Lowndes County, being exposed in the banks of Floating Turtle Creek a short distance east of Columbus.

Readjustment of the nomenclature.-From the facts brought out in the above discussion it is apparent that a readjustment of the nomenclature as applied by Hilgard to the beds subjacent to the Selma chalk in Mississippi is necessary. The classification of the corresponding deposits 
in Alabama by Smith and Johnson is based on essential physical differences, namely, those depending on origin. In Mississippi these differences were not recognized. It would appear, therefore, that the Alabama nomenclature is the more logical.

In the opinion of the writer, the name Tuscaloosa, which stands for the lower irregularly bedded portion of the series, or for that portion which originated in shallow water, should be extended to include the corresponding deposits in Mississippi.

The name Eutaw, which in Alabama stands for the upper or truly marine portion of the series, can appropriately be extended to include the corresponding beds in Mississippi, although this will mean the expansion of the term (as Hilgard used it) to include the Tombigbee sand above and its contraction to exclude the Mississippi representatives of the Tuscaloosa formation below.

The name Tombigbee sand, however, if applied to the actual type sections of the division given by Hilgard and to their equivalents, is expressive of a natural phase or subdivision of the Eutaw formation and is eminently worthy of preservation in the literature. If Hilgard's imperfect mapping is disregarded the sections of the Tombigbee sand given by him are all included within a thickness of strata which probably does not exceed 150 or 200 feet. Thus limited, the division includes the uppermost massive, glauconitic, more or less calcareous and phosphatic beds of the Eutaw formation, as distinguished from the more irregularly bedded and more argillaceous portion of the formation beneath it. These upper, massive beds are traceable for many miles northward from Lowndes County, in Mississippi, and with certain modifications they extend eastward entirely across Alabama into Georgia. They were recognized by Smith and Johnson and were spoken of by them as the "upper member of the Eutaw formation." This member, however, can not be sharply differentiated from the remainder or lower part of the formation, for massive lenses of glauconitic sand of greater or lesser extent occur in places at lower levels than the Tombigbee member proper and in small exposures are not distinguishable from that member.

The names Tuscaloosa and Eutaw were applied in Mississippi by Crider ${ }^{1}$ in 1906 in approximately the sense here proposed, but he did not give his reasons for discarding the classification of Hilgard in favor of that of Smith and Johnson.

Extent of the Tuscaloosa formation.-Beds representing the Tuscaloosa formation extend north from western Alabama in a wide belt, which includes the northwestern part of Alabama and a relatively narrow strip in the adjoining northeastern part of Mississippi. The formation as a whole, however, becomes rapidly thinner to the north and disappears in the vicinity of the Tennessee State line. It is doubtful if in the region of their outcrop the Mississippi representatives of the formation exceed a thickness of 400 feet. Hilgard did not differentiate these lower beds of shallow-water origin from the higher beds of truly marine origin but included them in his Eutaw formation, as shown by the map accompanying his report. The Tuscaloosa formation also extends from western Alabama eastward nearly to Alabama River, where the terrane is believed to pinch out rather abruptly between the unconformably subjacent Lower Cretaceous beds and the overlying Eutaw formation.

Extent of the Eutaw formation.-The Eutaw formation, as defined by Smith and Johnson, including the Tombigbee sand, extends northward through Mississippi without much change in stratigraphic boundaries, as far as northern Itawamba County. Here the upper boundary shifts abruptly to a much higher level, for in this region the basal part of the Selma chalk merges northward into massive marine sands indistinguishable in lithologic character from the typical Tombigbee sand. A tongue of impure, argillaceous, and sandy chalk, however, extends northward into the body of the Tombigbee member in eastern Lee County. (See Pl. IX, in pocket.) Still farther north in eastern Alcorn and western Tishomingo counties these massive beds merge horizontally into glauconitic marine strata characterized by irregular bedding and by thin laminæ and thinly laminated layers of dark clay. These extend northward as a narrow belt for a distance of 80 or 90 miles into Tennessee. This is the Coffee sand of Safford. ${ }^{2}$

\footnotetext{
1 Crider, A. F., Geology and mineral resources of Mississippi: Bull. U. S. Geol. Survey No. 283, 1906, pp. $12-16$.

2 Safford, J. M., On the Cretaceous and superior formations of west Tennessee: Am. Jour. Sci., 2d ser., vol. 37, 1864, pp. 360-372; Geology of Tennessee, 1869, pp. 411-414.
} 


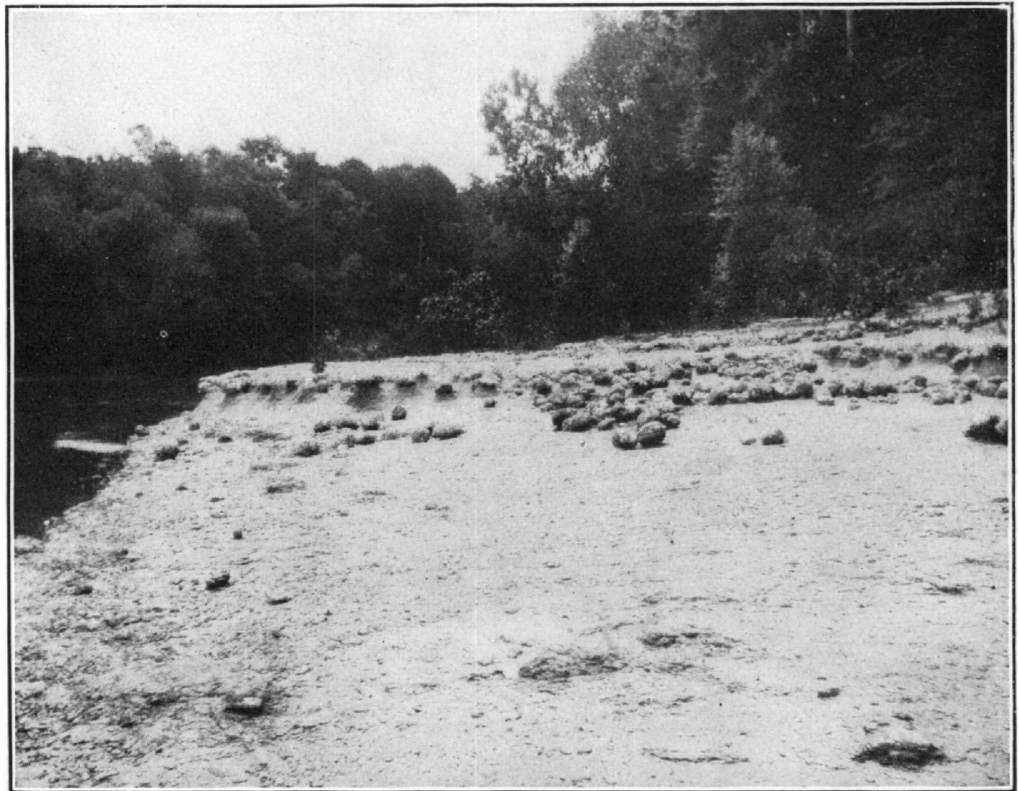

1. BASAL MARINE BEDS OF THE EUTAW FORMATION, BROKEN ARROW BEND, CHATTAHOOCHEE RIVER, ALABAMA SIDE, $10 \%$ MILES (BY THE RIVER) BELOW COLUMBUS, GA.

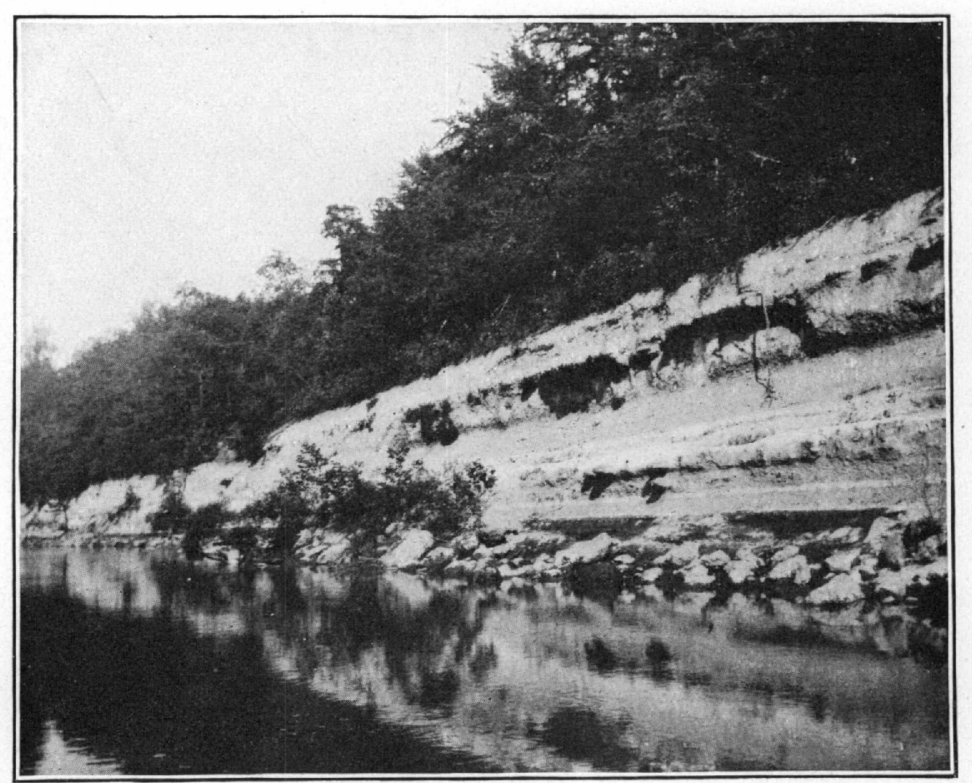

B. BEDS OF THE TOMBIGBEE SAND MEMBER OF THE EUTAW FORMATION AS DEVELOPED IN THE CHATTAHOOCHEE REGION, BANKS LANDING, CHATTAHOOCHEE RIVER, $26^{19}$ MILES (BY THE RIVER) BELOW COLUMBUS, GA. 

Lithologically the Coffee sand of Tennessee is strikingly similar to the part of the Eutaw formation below the Tombigbee sand member, with which it was correlated by Safford. This portion of the Eutaw (see Pls. IX, in pocket, and X, p. 20) is separated from the basal beds of the Eutaw by the intervening Tombigbee sand member. It seems appropriate, therefore, to give to these beds a separate designation, and for this reason Safford's term Coffee sand is here revived. The type exposure is in a bluff of Tennessee River just above Coffee Landing, Hardin County, Tenn. Plate III, $B$, shows a typical exposure of the Coffee sand member near Pittsburg Landing, on Tennessee River.

From western Alabama the Eutaw formation, including the Tombigbee sand member, extends eastward entirely across the State of Alabama into Georgia. In this direction the formation is underlain conformably by the Tuscaloosa formation to a line within a short distance west of Alabama River, where the Tuscaloosa pinches out rather abruptly between Lower Cretaceous beds which make their appearance equally abruptly, and the overlying Eutaw formation. From this place to its extreme eastern limit in Georgia the Eutaw is underlain unconformably by Lower Cretaceous strata. (See Pls. I, $B$, p. 10, and IV, $A$.)

In the Chattahoochee region the Eutaw formation includes the Eutaw group of Langdon ${ }^{1}$ and about 120 feet of the overlying beds which that author included in his Ripley group but which, on paleontologic grounds, are here correlated with the Tombigbee sand member of the Eutaw formation. The Blufftown marl of Veatch ${ }^{2}$ included these Tombigbee representatives and a part of the overlying Ripley formation. A typical exposure of the Tombigbee sand as developed on Chattahoochee River is shown in Plate IV, $B$.

SELMA CHALK.

Name.-The term "Rotten limestone," as previously explained, was introduced by Alexander Winchell ${ }^{3}$ in 1857 for the terrane now known as the Selma chalk. This descriptive name was the commonly accepted designation of this great body of chalk rock until the year 1894, when Smith, Langdon, and Johnson ${ }^{4}$ proposed the geographic term Selma chalk, as a coname with "Rotten limestone," and since then the geographic term has been the accepted designation.

Extent:- In western Alabama and east-central Mississippi the Selma chalk makes up all the Upper Cretaceous strata above the Tombigbee sand member of the Eutaw formation. The terrane rests conformably upon the Tombigbee sand and from the eastern part of Marengo County, Ala., to the northern part of Noxubee County, Miss., is overlain unconformably by Eocene strata carrying characteristic fossils.

Character.-The Selma chalk is described by Smith, Langdon, and Johnson ${ }^{5}$ as follows:

The rock is of comparatively uniform composition, being a gray to bluish-colored argillaceouslimestone, traversed at intervals by beds of purer limestone, which is at the same time a little harder in texture. In some places the material is a dark-bluish clay marl. ***

Mr. K. M. Cunningham, of Mobile, a well-known microscopist, undertook for me the investigation of the characteristic rocks of this formation, and the results of his examination of specimens collected from various points from Montgomery westward are given in the accompanying article by him. The statement has often been made that the true chalk is absent from the Cretaceous formations of North America, but we have here evidence that it is present in no inconsiderable proportions in Alabama, and Hill has recently shown that it occurs in Arkansas and in Texas, and we may reasonably infer that other States will yield upon closer examination very similar material.

In western Alabama the Selma chalk has a thickness of nearly 1,000 feet. The basal Eocene strata which in this region overlie the Selma chalk were formerly correlated with the Ripley formation. The error was corrected in part by Harris ${ }^{6}$ in 1896, in part by Smith $^{7}$ in 1910 , and in part by the writer. ${ }^{8}$ Typical exposures of the Selma chalk are shown in Plate V, $A$ and $B$.

1 Langdon, D. W., jr., Variations in the Cretaceous and Tertiary strata of Alabama: Bull. Geol. Soc. America, vol. 2, 1890, pp. 587-606.

2 Veatch, Otto, Second report on the clay deposits of Georgia: Bull. Geol. Survey Georgia No. 18, 1909, pp. 82-106.

${ }^{3}$ Winchell, Alexander, Statistics of some artesian wells of Alabama: Proc. Am. Assoc. Adv. Sci., vol. 10, pt. 2, 1857 , p. 91.

4 Smith, E. A., Langdon, D. W., jr., and Johnson, L. C., On the geology of the Coastal Plain of Alabama, Geol. Survey Alabama, 1894, p. 255.

${ }^{5}$ Idem, pp. 276, 285.

${ }^{6}$ Harris, G. D., The Midway stage: Bull. Am. Paleontology, vol. 1, No. 4, 1896, pp. 25-36 (139-150).

7 Smith, E. A., Cretaceous-Eocene contact, Tombigbee River, Ala.: Jour. Geology, vol. 18, No. 5, 1910, pp. 430-434.

3 Stephenson, L. W., unpublished notes on sections at Bridgeport and Old Canton landings, Alabama River, in Wilcox County, and at Livingston, in Sumter County. 
Lithologic subdivisions.-In 1903 Smith $^{1}$ divided the Selma chalk in Alabama into three parts on the basis of the relative content of lime and clay. The lower portion, which he estimates to include approximately one-third of the total thickness of the formation, contains 25 per cent or more of clayey impurities; this he called the Selma division. (See Pl. V, B.) The middle portion, estimated to embrace one-third of the total thickness, contains less than 25 per cent of clayey impurities; this he called the Demopolis division. (See Pl. V, A.) The upper portion, embracing the remainder of the formation, contains 25 per cent or more of clayey impurities; this he called the Portland division.

The purer phase of the chalk, Smith's Demopolis division, is traceable from western Alabama eastward in Alabama and northwestward and northward in Mississippi, but in each direction it becomes gradually thinner and less pure and eventually grades into impure sandy and argillaceous phases of the chalk rock. The impurities mentioned by Smith as distinguishing the lower and upper divisions of the chalk are not all of a clayey character, for important percentages of sandy impurities are known to be present in considerable thicknesses of the strata, especially in the upper division in western Alabama and east-central Mississippi.

Eastward in Alabama and northward in Mississippi the Selma chalk merges along the strike of the beds into nonchalky equivalents. This relation, as regards eastern Alabama, was formerly recognized as probable by the Alabama geologists (as shown by the quotations given below), but the vertical ranges of the fossils were not at the time sufficiently well known to permit a positive statement.

It will be seen that the main variation from the western Alabama type consists in thev ery great increase in the area occupied by the strata of the Ripley type in the eastern part of the State. Whether this results in part from an increase in the thickness of the strata themselves or from undulations in them may not perhaps be definitely asserted, but, taken in connection with the apparent absence of all the strata that can be referred to the Rotten limestone, it seems most probable that there is actually much greater thickness of the rocks of the Ripley type along the Chattahoochee and its vicinity than farther west, and that the Rotten limestone is replaced or represented by strata of the physical aspect of the Ripley. The paleontology of these two divisions of the Cretaceous has not been very well worked out, so that the shells give us comparatively little help in the matter, especially when we consider the fact that in the Rotten limestone, although it has a very large number of shells in its strata, these shells are of very few kinds and mostly of those kinds that are common in the Ripley strata also. ${ }^{2}$

East of the drainage of the Alabama River the Rotten limestone, such as occurs in Marengo, Perry, Dallas, Lowndes, and Montgomery counties, is not represented. The exact eastern limit of this group has not as yet been determined, but evidences of its decreasing thickness are seen in the narrow outcrop in the neighborhood of Pike road, Montgomery County, where its north and south extent is only 5 miles as contrasted with 30 miles in Dallas County. Further than this decrease in thickness our present information does not warrant us in saying anything. As has been stated before, no rocks bearing any lithologic resemblance to the Rotten limestone have been seen on the Chattahoochee River, whether or not this group is represented by strata of different composition from the typical aluminous limestone we are not in position to say, since no critical examination of the fossils of the several divisions of the Cretaceous has yet been undertaken. It is much to be regretted that the divisions have been of necessity made on such arbitrary grounds as mere lithologic differences, since marked variations can be noted in almost any stratum of any of the groups, and experience in both the Tertiary and Cretaceous of Alabama has proved the risk of creating groups on any but combined physical and faunal differences. ${ }^{3}$

Deposition.-When the formation of the Selma chalk began, the conditions favorable to this sort of deposition existed throughout an offshore area extending from western Russell County, Ala., to Itawamba County, Miss., a distance of approximately 300 miles. As Upper Cretaceous time progressed the area in which chalk was being laid down underwent certain marked expansions and contractions due to fluctuating conditions of sedimentation. In Mississippi conditions unfavorable to the deposition of chalk at first spread gradually southwestward from Itawamba County for 15 or 20 miles, producing the tongue of Tombigbee sand which extends from the north to the south through Lee County. (See Pl. IX, in pocket.) This was followed by a rapid northward extension of conditions favorable to the deposition of impure chalk, thus producing a long tongue of Selma chalk reaching as far as Hardin County, Tenn. Then succeeded a more gradual spreading of unfavorable conditions southward through

${ }^{1}$ Smith, E. A., The Portland cement materials of central and southern Alabama: S. Doc. No. 19, 58th Cong., 1st sess., 1903, pp. 12-23, map.

ismith, E. A., Langdon, D. W., jr., and Johnson, L. C., On the geology of the Coastal Plain of Alabama, Geol. Survey Alabama, 1894, pp. 275, 276.

Idem, pp. 430, 431. 


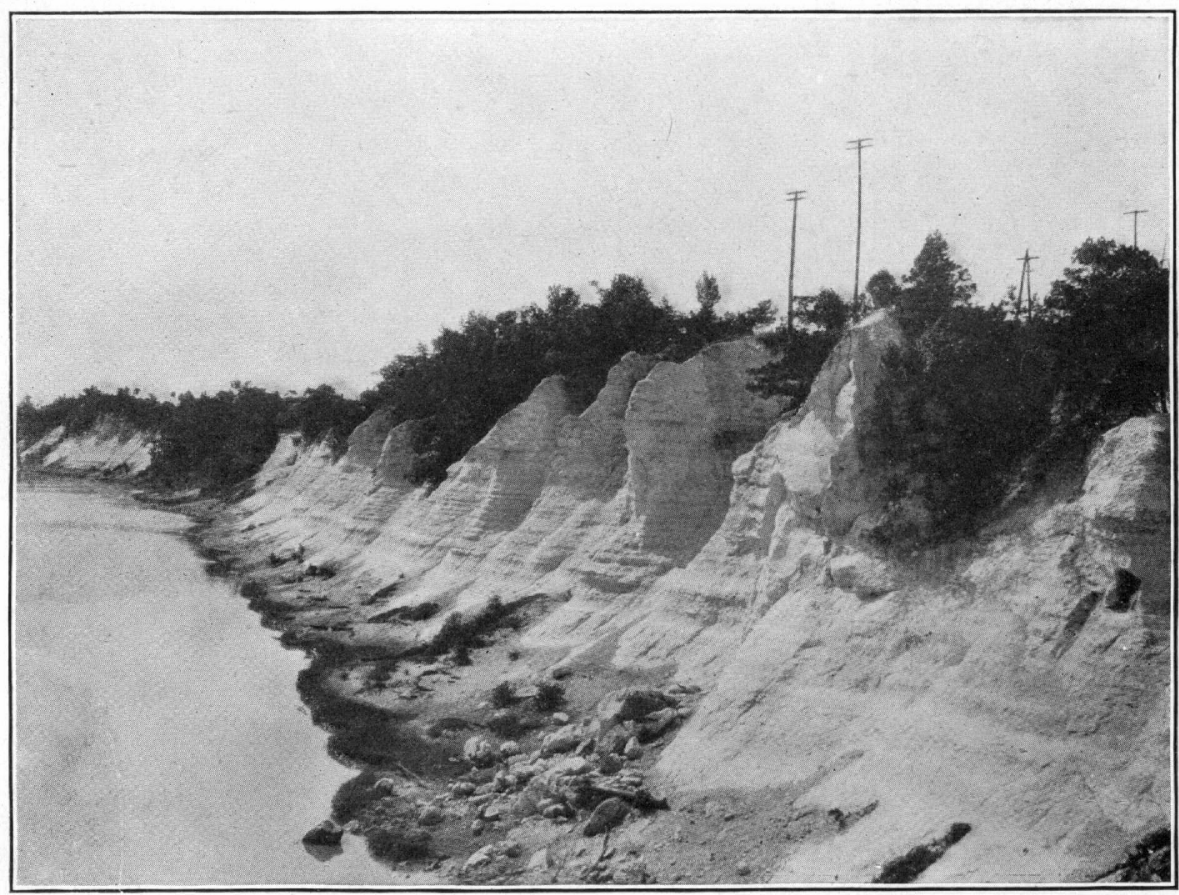

A. TYPICAL EXPOSURE OF THE SELMA CHALK, JONES BLUFF, TOMBIGBEe RIVER, NEAR EPES, SUMTER COUNTY, ALA.

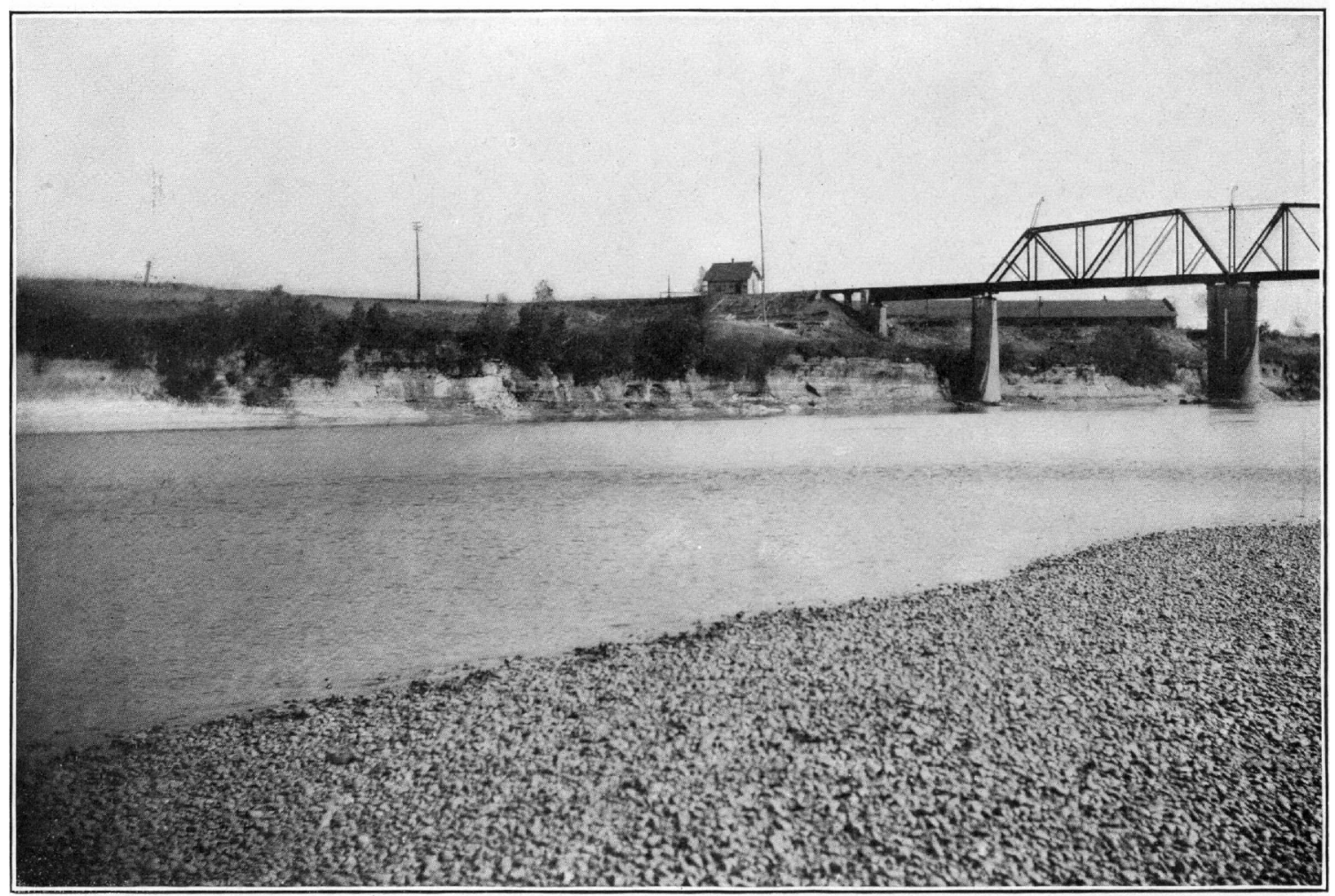

B. SELMA CHALK AT ITS TYPE LOCALITY, ALABAMA RIVER, SELMA, ALA. 


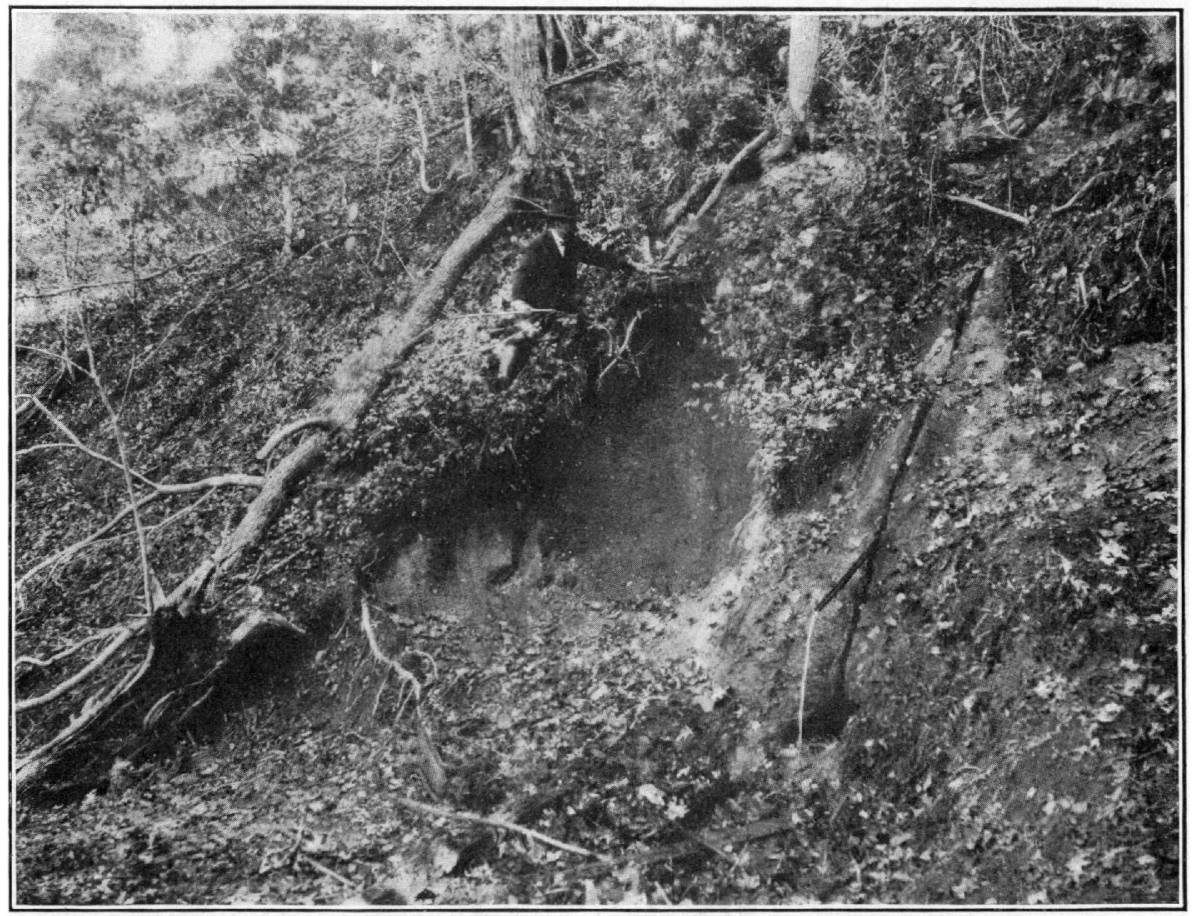

A. CLASSIC FOSSIL LOCALITY OF THE RIPLEY FORMATION, BLUFF ON OWL CREEK, 3 MILES NORTHEAST OF RIPLEY, TIPPAH COUNTY, MISS.

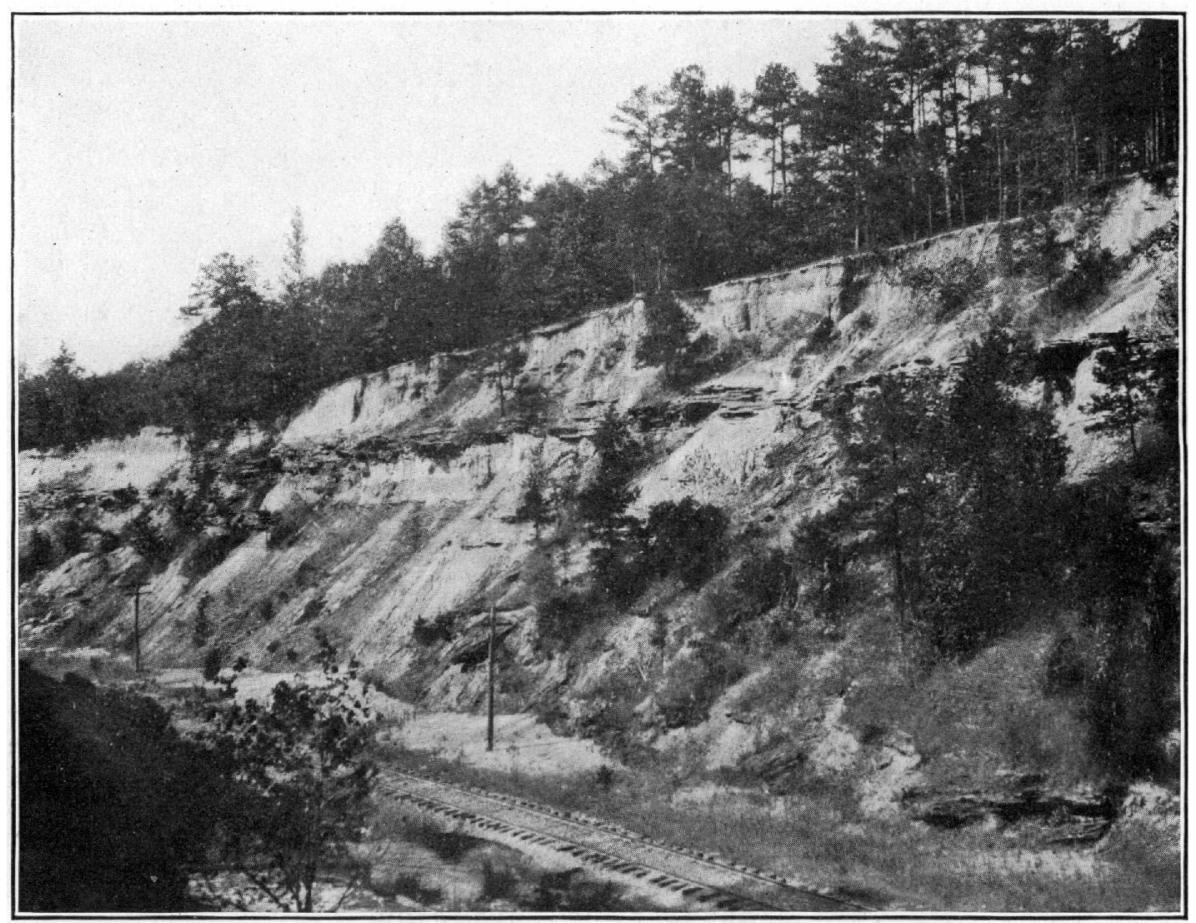

B. BEDS OF THE MCNAIRY SAND MEMBER OF THE RIPLEY FORMATION, CUT OF SOUTHERN RAILWAY 11/4 MILES WEST OF CYPRESS, MCNAIRY COUNTY, TENN. 
Mississippi to the northern part of Noxubee County; this resulted in the production in Tennessee and Mississippi of the nonchalky Ripley formation above the Selma chalk. Finally there was another expansion of favorable conditions northward to a short distance north of Houston in Chickasaw County, forming the long narrow strip of chalk rock which makes up the extreme uppermost strata of the Cretaceous above the sands of the Ripley formation in Oktibbeha, Clay, and Chickasaw counties. (See Pl. IX.)

In Mississippi, therefore, part of the Selma chalk is replaced by synchronous nonchalky beds, and northward in Tennessee all of the Selma is eventually thus replaced. In northern Mississippi and in Tennessee the nonchalky time equivalents of the basal portion of the Selma are referred to the Eutaw formation, and these equivalents include a part of the Tombigbee sand member of the Eutaw formation and all of the Coffee sand member of the Eutaw. (See Pls. IX, in pocket, and X, p. 20; also pp. 12-15 and 21.) The time equivalents of the upper part of the Selma in Mississippi and northward in Tennessee, Kentucky, and southern Illinois are referred to the Ripley formation.

In eastern Alabama, immediately after the beginning of chalk deposition, the conditions unfavorable to the formation of chalk gradually spread westward from Russell County, the materials laid down in the east being nonchalky marine beds which are here referred to the Ripley formation. Near the close of Upper Cretaceous sedimentation, as the record is preserved, these unfavorable conditions had reached nearly to the western part of Marengo County, Ala. (See Pl. IX.) There was then a sudden eastward extension of favorable conditions, producing the long strip of chalk rock which extends above the sands of the Ripley almost to the eastern part of Dallas County and which forms the extreme uppermost beds of the Cretaceous along this distance. This is the "Prairie Bluff limestone" of Winchell." As shown by the fossils, this rock is exactly synchronous with the similar tongue of chalk in Oktibbeha, Clay, and Chickasaw counties, Miss., described above.

Paleontologic subdivisions. - The Selma chalk in the region of its fullest development is divisible on paleontologic grounds into two parts; the lower, embracing approximately the lower half of the formation, is most conspicuously characterized by the presence of Exogyra ponderos a Roemer; the upper, embracing the remainder of the formation, is characterized by the presence of Exogyra costata Say and carries a fauna, especially near its top, which corresponds in a general way with the fauna of the originally described Ripley formation exposed in the bluffs of Owl Creek, 3 miles northeast of Ripley, Tippah County, Miss., though it contains fewer species.

\section{RIPLEY FORMATION.}

Mississippi.-The typical materials of the Ripley formation consist of marine, more or less calcareous and glauconitic sands, sandy clays, impure limestones, and marls. These were originally described by Hilgard." The bluffs of Owl Creek, 3 miles northeast of Ripley, Tippah County, Miss., may be considered the type locality of the formation. One of the classic Owl Creek exposures is shown in Plate VI, $A$. Eocene limestones (Midway formation) which immediately overlie the Ripley formation in the Owl Creek region were included by Hilgard in the Ripley. . This error in correlation was corrected by Harris, ${ }^{3}$ in 1896.

Tennessee and northward.--In the vicinity of the Tennessee State line and northward in Tennessee all but the basal beds of the formation appear to merge along the strike into shallow-water equivalents consisting of irregularly bedded, largely nonglauconitic sands and subordinate clays, probably in part of marine, in part of estuarine, and in part of fresh-water origin. Since the time of Safford ${ }^{4}$ these have been correlated with the Ripley formation. Their lithologic dissimilarity to the typical materials of the Ripley formation seems to justify the use of a member name to designate them, and the name McNairy sand member, derived

\footnotetext{
1 Winchell, Alexander, Statistics of some artesian wells of Alabama: Proc. Am. Assoc. Adv. Sci., vol. 10, pt. 2, 1857, p. 90.

2 Hilgard, E. W., Geology and agriculture of Mississippi, 1860, pp. 83-95.

a Harris, G. D., The Midway stage: Bull. Am. Paleontology, vol. 1, No. 4, 1896, pp. 22-25 (136-139).

4 Safford, J. M., On the Cretaceous and superior formations of west Tennessee: Am. Jour. Sci., vol. 37, 1864, pp. 360-372; Geology of Tennessee, 1869 , p. 550, plates and map. $105^{\circ}-$ No. $81-14-2$
} 
from McNairy County, Tenn., is proposed. The type section of this member is exposed in a cut of the Southern Railway $1 \frac{1}{4}$ miles west of Cypress station in this county, where the railroad passes through a ridge known as "Big Hill." (See Pl. VI, B.) A section of this cut is given below:

Section of McNairy sand member of Ripley formation in cut on Southern Railway $1 \frac{1}{1}$ miles west of Cypress station, McNairy County, Tenn.

6. Yellowish sandy loam, grading down into reddish argillaceous, rather coarse sand with irreg-

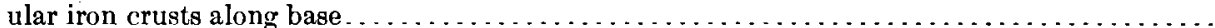

5. Coarse, loose cross-bedded varicolored sand with scattered small white clay films and pellets and with irregular eandy iron concretions in upper 2 feet........................ $17-24$

4. Coarse corrugated ferruginous sandstone presenting many parallel cavities, round to irregular in cross section, of all diameters up to a foot or more, the cavities all pointing northeast and southwest. Pockets of varicolored sand occur intermixed with the ironstone masses....... 3-10

3. Massive, loose, fine micaceous sand, pale yellowish green in upper part and blotched and streaked with purple in lower part.......................................... 20

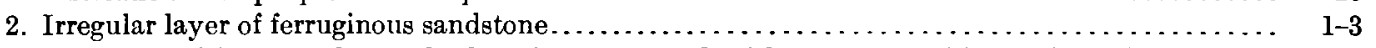

1. Pale yellowish-green, loose, finely micaceous sand with numerous thin laminæ of white and drab clay; toward the western end of the cut short, relatively thick lenses of black, carbonaceous clay reaching a maximum thickness of 8 or 10 feet. The black clay contains a few

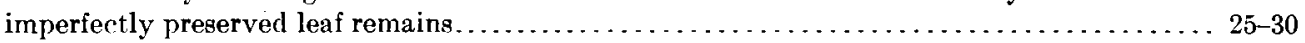

The McNairy member extends northward as a belt 5 to 15 miles in width, through Tennessee and Kentucky, to the southern extremity of Illinois. It is correlated with the Ripley formation, chiefly on the grounds of supposed continuity of strata. So far as known to the writer the only paleontologic evidence throwing light on the age of the member is that furnished by a single fossil found near Cairo, Ill. This specimen was discovered in an excavation for a bridge pier and later came into the possession of the State Museum at Springfield, Ill. Thence it was sent to Dr. C. A. White, at the National Museum, Washington, D. C., and was identified by him as Exogyra costata Say. Recently the specimen was again sent to Washington by request and was determined by the writer to be a typical specimen of Exogyra costata var. cancellata Stephenson. The information given on the label accompanying the specimen is as follows: "Specimen No. 8358 of the State Natural History Museum, Springfield, Ill. Locality: Bottom of Ohio River; found in sinking a caisson for Illinois Central Railroad bridge near Cairo, Ill." The shell was not waterworn. Portions of the matrix in which the shell was originally embedded, adhering to the surface, consisted of fine gray calcareous, argillaceous, micaceous marine sand. Although from the account of its discovery it can not be positively asserted that this specimen of Exogyra was in its original position in marine sand where found, the assumption that it was in place seems reasonable. Whether this marine sand exists as a lens in the predominantly shallow-water beds of the McNairy sand member or constitutes a northward extension of the stratigraphically lower, purely marine strata of the Ripley formation of Tennessee, which in Kentucky and Illinois have become overlapped and buried by the beds of the McNairy member, is not definitely known. However, on the assumption that the specimen belonged in place where found, the Cretaceous sea is shown to have extended, probably as a broad, open embayment, as far north as Cairo. On the same assumption the containing beds belong stratigraphically within the zone of Exogyra costata (see p. 23) somewhere below the Liopistha protexta subzone.

Safford included in his Ripley certain fossiliferous beds in eastern Hardeman County, Tenn., which Harris ${ }^{1}$ later showed to belong to the overlying Midway formation of the Eocene.

Alabama and Georgia.-The time equivalents of the Selma chalk in eastern Alabama and in Georgia are referred in their entirety to the Ripley formation. The strata, except certain lithologic variations described below as members, are similar lithologically to the typical materials of the Ripley formation of northern Mississippi. They consist in the main of dark-gray or greenish-gray more or less calcareous and glauconitic sands, sandy clays, impure limestones, and marls of marine origin. These beds constituted the Ripley group 


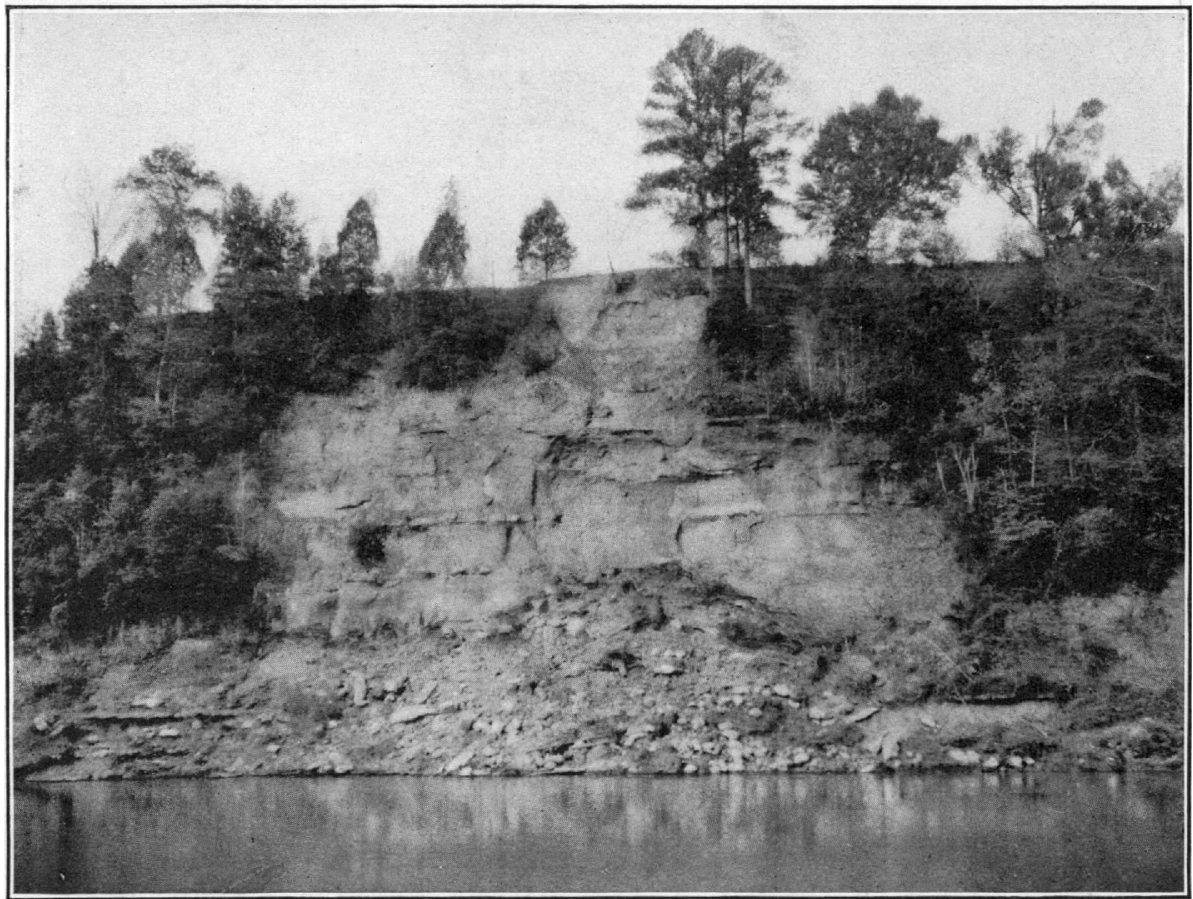

A. MARINE BEDS OF THE RIPLEY FORMATION, CHATTAHOOCHEE RIVER, EUFAULA, ALA.

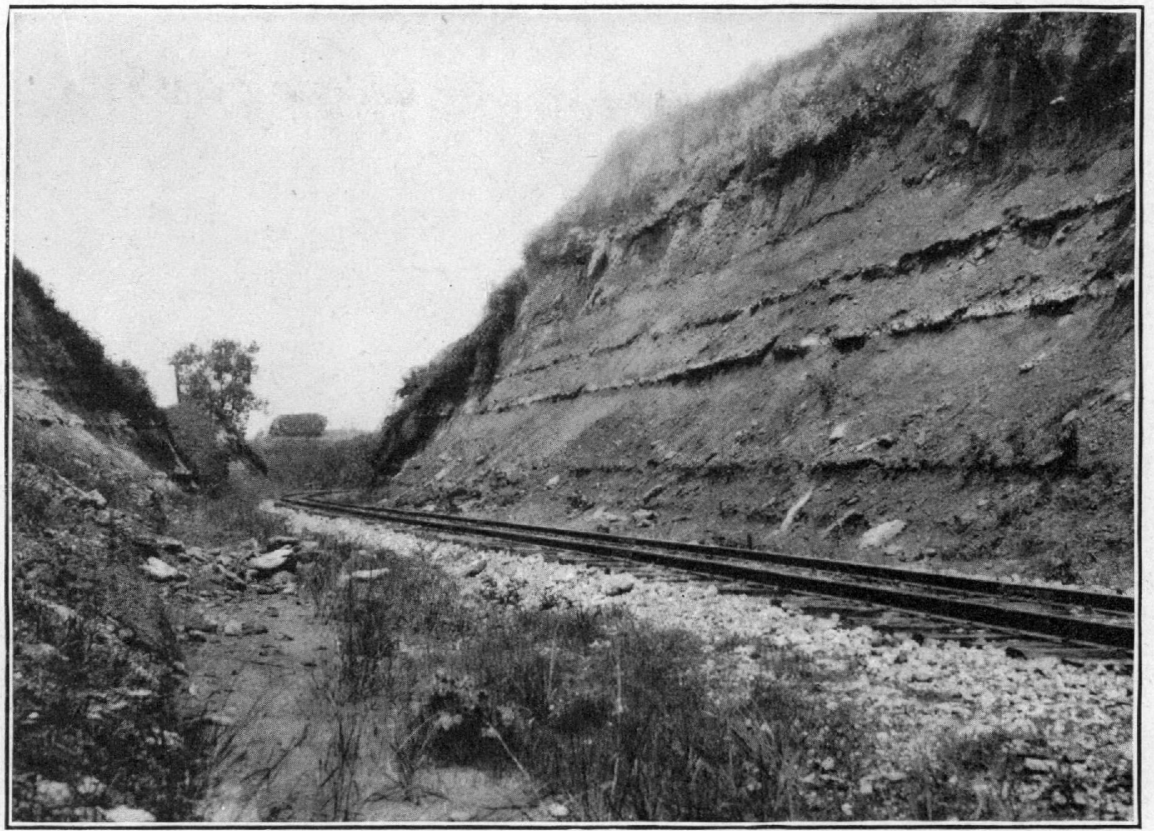

B. MARINE BEDS OF THE RIPLEY FORMATION, CUT OF LOUISVILLE \& NASHVILLE RAILROAD $13 / 8$ MILES NORTH OF FORT DEPOSIT, LOWNDES COUNTY, ALA. 


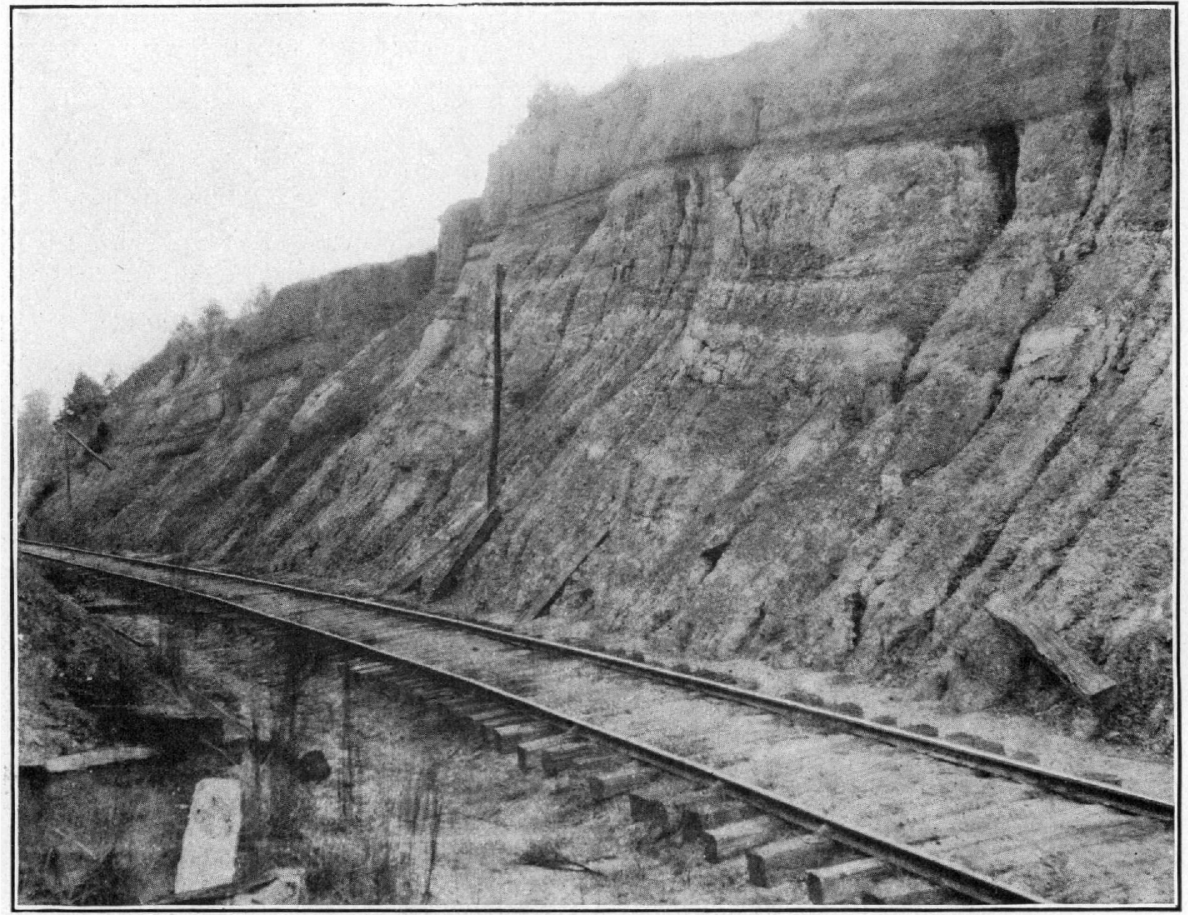

A. CUSSETA SAND MEMBER OF THE RIPLEY FORMATION OVERLAIN BY TYPICAL MARINE BEDS OF THE FORMATION, CUT OF SEABOARD AIR LINE RAILWAY AT HICHITEE (MANTA STATION), CHATTAHOOCHEE COUNTY, GA.

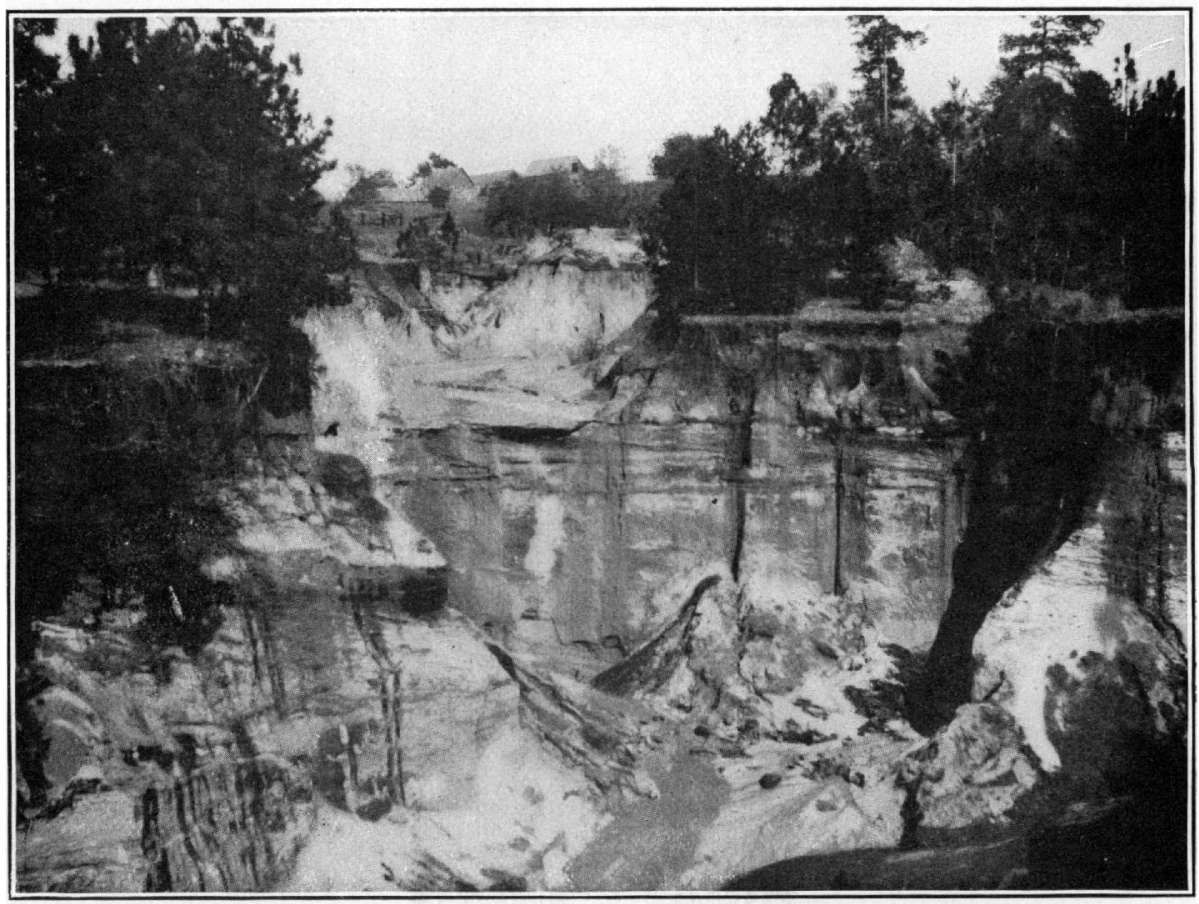

B. BEDS OF PROVIDENCE SAND MEMBER OF THE RIPLEY FORMATION, GULLY NEAR EUFAULA-LUMPKIN ROAD 101/2 MILES NORTHEAST OF GEORGETOWN, GA. 
of Langdon ${ }^{1}$ except that he included in the division an additional 120 feet of strata at the base of the series, which are here, on paleontologic grounds, correlated with the Tombigbee sand member of the Eutaw formation.

The Ripley formation of the Chattahoochee-region is divisible paleontologically on the basis of the ranges of the contained species of Exogyra exactly in the same manner as was stated to be true of the Selma chalk. The lower part, embracing the lower one-third to one-half of the formation, is characterized by the presence of Exogyra ponderosa Roemer and Exogyra ponderosa var. erraticostata Stephenson; the upper, embracing the remainder of the formation, is characterized by the presence of Exogyra costata Say. The formation contains a large number of invertebrate species which range from the base, or even from below the base of the formation, to its top, and it contains also a number of species with restricted ranges, some confined above and some below the horizon separating the two types of Exogyra. Typical exposures of the Ripley strata are shown in Plate VII, $A, B$.

Northeastward from Chattahoochee River in Georgia the equivalents of the Ripley formation pass first into a series of alternating marine and shallow-water beds and still farther northeastward into irregularly bedded sands and clays of shallow-water origin, overlapped and concealed in central and eastern Georgia by Eocene beds.

The classification of the Georgia Cretaccous deposits adopted by Otto Veatch in $1909 \%$ is essentially the same as that of Langdon, except that Veatch subdivided the Ripley into four parts-Blufftown marl, Cusseta sand, Renfroes marl, and Providence sand-on the basis of the alternation of beds of marine and shallow-water origin recognizable in a part of the area.

A part of the "Blufftown marl," as previously explained, is here correlated with the Tombigbee sand member of the Eutaw formation. The remainder of the "Blufftown" and the "Renfroes marl" are lithologically indistinguishable from the typical Ripley and require no separate designation.

The basal part of the Ripley formation, embracing 200 or 300 feet of strata, merges northeastward from the Chattahoochee region into irregularly bedded, nonglauconitic sands with subordinate lenses of clay, probably in part of shallow marine, in part of estuarine, and in part of fresh-water origin. These constitute the Cusseta sand member of the formation. (See Pl. VIII, A.)

The upper part of the formation also merges northeastward along the strike into irregularly bedded sands and clays similar to those of the Cusseta sand member. This is the Providence sand member of the formation. A typical exposure is shown in Plate VIII, $B$. At its type section near Providence post office (now abandoned) about 8 miles west of Lumpkin, Stewart County, the member has a total thickness of 140 or 150 feet. The Providence sand is also represented west of Chattahoochee River along the southern border of the Cretaceous area in Barbour, Bullock, and Pike counties. It is believed that the top of the Providence sand member occupies a slightly higher stratigraphic position than the top of the Cretaceous farther west in the eastern Gulf region.

Both the Cusseta sand member and the Providence sand member increase in thickness northeastward, whereas the intervening typical beds of the formation, the "Renfroes marl" of Veatch, become gradually thinner, and eventually in Macon County appear to pinch out entirely. The entire thickness of the formation beyond this point to the east is apparently represented by the Cusseta and Providence members.

\section{SUMMARY OF PRESENT CLASSIFICATION.} GENERAL SEQUENCE.

The areal distribution of the several formations and members recognized in tne castern Gulf region is shown on the geologic map ( $\mathrm{Pl}$. IX, in pocket). Their stratigraphic positions, lithologic variations, and age equivalencies, are graphically represented in the diagram, Plate X.

An unconformity of regional extent separates the Lower Cretaceous deposits from those of Upper Cretaceous age. The Upper Cretaceous deposits are believed to form in the main a

1 Langdon, D. W., jr., Variations in the Cretaceous and Tertiary strata of Alabama: Bull. Geol. Soc. America, vol. 2, 1891, pp. 587-606.

2 Veatch, Otto, Second report on the clay deposits of Georgia: Bull. Geol. Survey Georgia No. 18, 1909, pp. 82-106. 
conformable series, although there are local unconformities of slight time importance in some of the shallow-water phases of the series.

The Upper Cretaceous deposits throughout the extent of their occurrence in the eastern Gulf region are overlain unconformably by Eocene strata.

\section{LOWER CRETACEOUS.}

The oldest Cretaceous strata of the region constitute a terrane which in areal distribution extends from the Alabama River valley, north of Montgomery, Ala., eastward through Alabama to the Chattahoochee River valley, at and immediately south of Columbus, Ga., and thence northeastward through Georgia, intersecting the Savannah River valley at and south of Augusta, Ga.

The materials consist of irregularly bedded, coarse, arkosic, more or less micaceous sand, with subordinate lenses of usually massive clay of greater or lesser purity. The terrane rests upon a basement of crystalline rocks and is separated from the overlying Eutaw and other Upper Cretaceous and Tertiary formations by an unconformity. A short distance west of Alabama River the formation passes unconformably beneath and is completely buried by overlapping strata of the Tuscaloosa formation.

Fossil plants have been found in the terrane at one locality in Alabama.

UPPER CRETACEOUS.

TUSCALOOSA FORMATION.

The Tuscaloosa formation consists of irregularly bedded sands, clays, and gravels: having, an estimated total thickness of 1,000 feet. The sands, even well down toward the base of the formation, are in places slightly glauconitic; the clays are in part massive and in part thinly laminated and are not uncommonly carbonaceous and lignitic; both the sands and elays vary in color from light drabs and grays to dark greens or grays, and are in many places varicolored, being blotched with purples, reds, pinks, yellows, and browns; the gravels occur chiefly in the basal beds of the formation near their contact with the underlying basement roeks.

The formation rests unconformably upon a basement which consists chiefly of Paleozoic rocks, but in part, toward the eastern end of the area, of crystalline rocks of probable preCambrian age, and in part, at the extreme eastern end of its occurrence, of Lower Cretaceous strata. The terrane is overlain conformably by the Eutaw formation. The Tuscalooss formation has yielded a large number of fossil plant species.

\section{EUTAW FORMATION.}

Typical beds.-The Eutaw formation consists predominantly of more or less glauconitic sand, massive to cross-bedded in structure, with, in parts of the terrane, irregularly interbedded fine laminæ and laminated layers of dark clay, the latter usually containing comminuted plant fragments and some lignite. In places the beds are calcareous, this being especially true of the basal part of the formation in the Chattahoochee region and of the uppermost beds of the division throughout the greater part of its linear extent. The total thickness of the formation is estimated to be 400 to 500 feet. The beds are believed to be entirely of marine origin, although much of the formation was doubtless laid down in very shallow marine waters. On the basis of the distribution of massive as opposed to laminated beds two members described below are differentiated within the formation.

The terrane rests with conformable relations upon the underlying Tuscaloosa formation, and is overlain conformably in part by the Selma chalk and in part by the Ripley formation.

Marine invertebrate fossils occur abundantly in the basal 100 or 150 feet of the formation in the Chattahoochee region. Fossils also occur abundantly in places in the Tombigbee member of the formation, as explained below. Fossil plants have been found at two horizons below the Tombigbee member in the Chattahoochee region. 


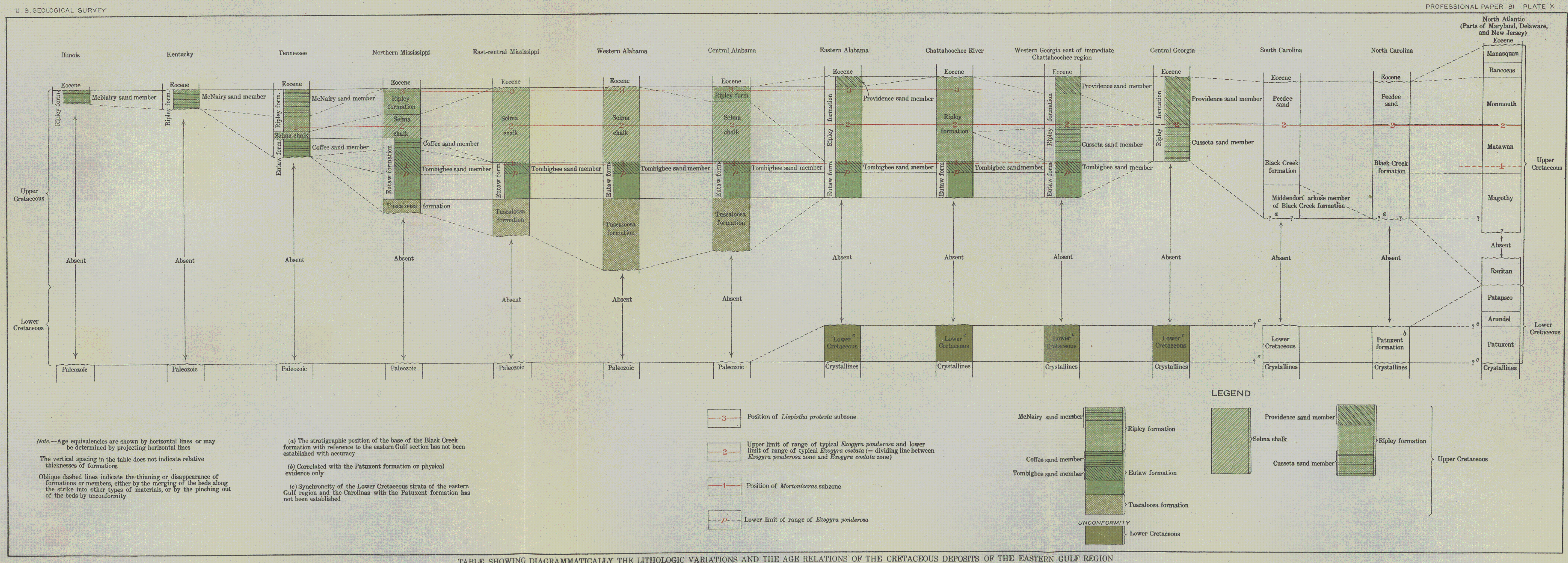

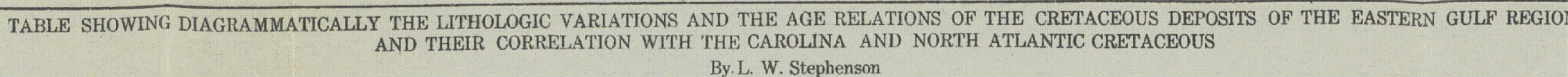





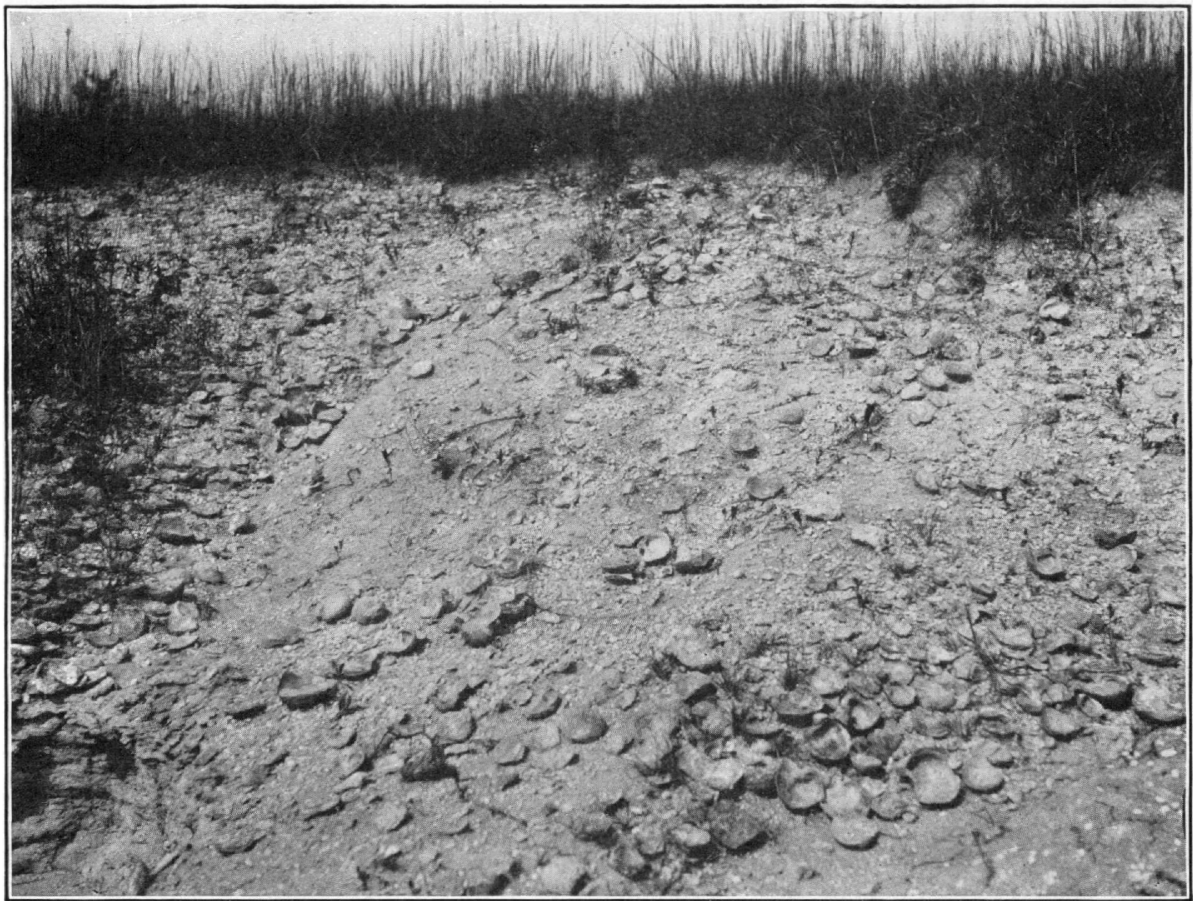

A. SPECIMENS OF EXOGYRA COSTATA, EXOGYRA COSTATA VAR. CANCELLATA (NUMEROUS), GRYPHAEA VESICULARIS, ANOMIA ARGENTARIA, KNOB," JOSEPH REYNOLDS PLACE, 3 MILES WEST OF CORINTH, ALCORN COUNTY, MISS.

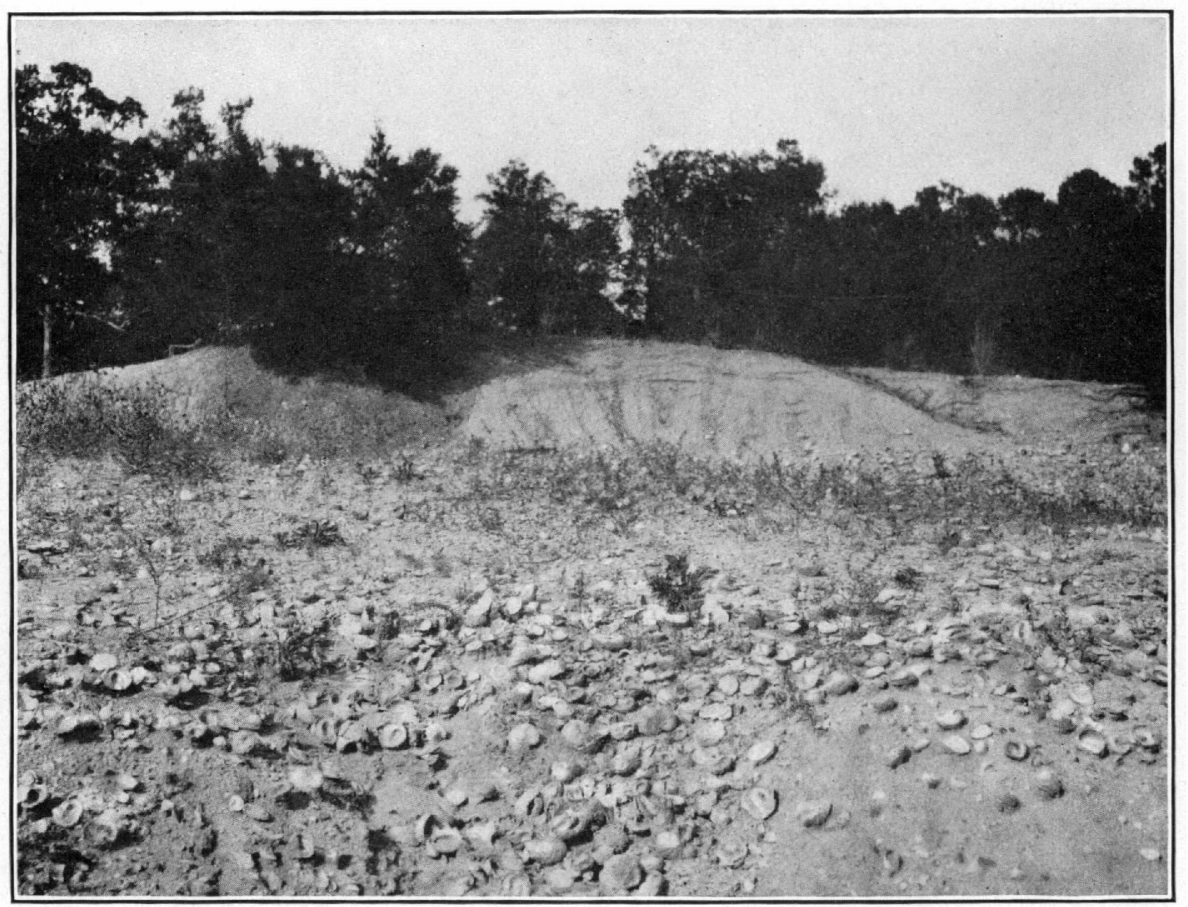

B. SPECIMENS OF EXOGYRA PONDEROSA, EXOGYRA PONDEROSA VAR. ERRATICOSTATA INUMEROUS), GRYPHAEA AUCELLA, AND OTHER FOSSILS, WEATHERED FROM BASAL BEDS OF SELMA CHALK NEAR PUBLIC ROAD, 1 MILE WEST OF COTTON GIN PORT, MONROE COUNTY, MISS. 

Tombigbee sand member.-The Tombigbee sand member consists of massive, glauconitic, more or less calcareous and argillaceous sand. Through Georgia, Alabama, and east-central Mississippi it constitutes the upper 100 to 200 feet of the formation. In northern Mississippi it thickens above, embracing within its stratigraphic limits beds which are the time equivalents of a portion of the overlying Selma chalk.

Marine invertebrate fossils are common in the lower and upper parts of the member in the Chattahoochee region and are numerous in the upper 50 or 75 feet of strata in Alabama and in east-central Mississippi; they occur also at several hrorizons in the thickened portion of the member in northern Mississippi. The teeth of fishes, particularly those of sharks, are numerous in the uppermost beds of the member in Alabama and in east-central Mississippi, and with them occur other scattered, fragmental, vertebrate remains.

Coffee sand member.-The Coffee sand member consists predominantly of glauconitic sands characterized by irregularity of bedding and by the presence of thin laminæ and thinly laminated layers of dark clay. The beds are the Tennessee representatives of the thickened portion of the Tombigbee sand member of northern Mississippi, which in turn represents the time equivalent of the basal portion of the Selma chalk. (See Pl. X.) The division has an estimated maximum thickness of 200 to 300 feet. The beds contain an abundance of comminuted plant fragments and scattered pieces of lignite. The member has yielded one identifiable fossil leaf, Salix eutawensis Berry (identified by E. W. Berry). (See p. 26.)

$$
\text { SELMA CHALK. }
$$

The Selma chalk consists in the main of more or less argillaceous and sandy limestones rendered chalky by their large content of foraminiferal remains, with interbedded layers of nearly pure, hard limestone at wide intervals. In western Alabama the terrane has a measured maximum thickness of 930 feet as determined by the record of a well at Livingston, in Sumter County. The formation rests conformably upon the Eutaw formation, and where it attains its maximum development in western Alabama and in east-central Mississippi is overlain unconformably by Eocene strata.

The chalk beds merge along the strike in either direction into nonchalky equivalents, which in northern Mississippi and Tennessee are included in part in the Tombigbee and Coffee sand members of the Eutaw formation and in part in the Ripley formation, and in eastern Alabama are included entirely within the Ripley formation.

In addition to Foraminifera, the chalk beds contain invertebrate fossils in greater or lesser abundance throughout their vertical and horizontal extent, the most conspicuous of which belong to the families Ostreidæ and Anomiidæ. Fossils are especially abundant in places in the impure, argillaceous phases of the terrane and weather out in great numbers. (See Pl.XI, $A, B$.$) The chalk also contains scattered sharks' teeth and other fragmental vertebrate remains.$

RIPIEY FORMATION.

MISSISSIPPI, TENNESSEE, KENTUCKY, AND ILLINOIS.

Typical beds.-The typical beds of the Ripley formation consist of more or less calcareous and glauconitic sands, sandy clays, impure limestones, and marls, of marine origin, reaching an estimated maximum thickness in this region of 250 to 350 feet. The formation rests with conformable relations in part upon Paleozoic rocks, in part upon the Eutaw formation (in Tennessee), and in part upon the Selma chalk. From Tennessee and northern Mississippi southward the successively higher beds merge along the strike into the chalky limestones of the Selma formation. Northward the typical beds of the Ripley formation are believed to merge horizontally into a series of sands and clays of shallow-water origin, to which the name McNairy sand member is given. The formation is overlain unconformably by Tertiary beds of Eocene age.

The typical beds of the Ripley formation contain in many places an abundance of invertebrate fossil remains, some of which are in a remarkably perfect state of preservation. Sharks' teeth occur scattered sparingly through the deposits, which also contain a few fragments of bones. 
McNairy sand member.-In the vicinity of the Tennessee State line the typical beds of the Ripley formation, except for a small thickness at the base, appear to merge along the strike into irregularly bedded, nonglauconitic sands and subordinate clays, for the most part of shallowwater origin. Their lithologic dissimilarity to the typical Ripley makes desirable a separate designation for them, and the name McNairy sand member, derived from McNairy County, Tenn., is proposed. This member probably reaches a maximum thickness of 400 or 500 feet. The beds have yielded a few imperfectly preserved leaf remains.

ALABAMA AND GEORGIA.

Typical beds.-The Ripley of eastern Alabama and of the immediate Chattahoochee region in Georgia resembles in all essential physical characters the Ripley of the type region in northern Mississippi. The total estimated thickness of the formation in the Chattahoochee region is 950 feet. The Ripley rests with conformable relations upon the Eutaw formation. From the base upward the successively higher beds merge along the strike westward in Alabama into the Selma chalk. Along the southern border of the formation in Alabama and northeastward in Georgia portions of the formation, and eventually all of the formation, merge into lithologically dissimilar materials. These variations from the typical materials are described below as members.

The formation is overlain unconformably by Eocene strata.

As in Mississippi, the typical Ripley in this region contains an abundance of invertebrate fossil remains which are at many places in a fine state of preservation. Scattered fragmentary vertebrate remains occur, including bones and teeth. 'Poorly preserved fossil leaves have been discovered in marine materials at one locality.

Cusseta sand member.-Northeast of the Chattahoochee region in Georgia the basal 200 or 300 feet of the formation merges along the strike of the beds into fine to coarse, irregularly bedded, nonglauconitic and noncalcareous sands with subordinate clay lenses, for the most part of shallow-marine, but perhaps in part of estuarine and in part of fresh-water origin. These constitute the Cusseta sand member of the formation. No invertebrate fossils have been found in this member. A few species of fossil leaves have been found at two localities.

Providence sand member.-The upper beds of the Ripley formation also merge northeastward into irregularly bedded sands and clays similar to those of the Cusseta sand member. These form the Providence sand member of the formation. The thickness of this member at its type section near Providence post office (now abandoned), 8 miles west of Lumpkin in Stewart County, is 140 or 150 feet. Northeastward from the type locality the total thickness of the member increases, and the underlying typical beds of the Ripley, the "Renfroes marl" of Veatch, which intervenes between the Cusseta and Providence members, becomes thinner and appears to pinch out entirely in Macon County; beyond this county to the eastern extremity of its areal occurrence the entire thickness of the formation appears to be made up of these two members. The Providence sand is also represented west of Chattahoochee River along the southern border of the Cretaceous area in Barbour, Bullock, and Pike counties, Ala.

No fossil remains have been found in this member.

\section{SURFICIAL DEPOSITS.}

The Cretaceous deposits are overlain locally in their area of outcrop by relatively thin surficial deposits, which have been disregarded in the mapping because their distribution has not been determined in sufficient detail and because their representation is not germane to the problems treated in this report.

The surficial deposits consist chiefly of gravels, sands, clays, and loams. Some of them occupy the uplands between the streams and belong to the class of deposits commonly referred to the Lafayette formation (Pliocene?); the remainder are disposed along the sides of the river valleys in the form of terrace deposits and are of Pleistocene and Recent age. Terraces are well developed along Tombigbee, Marion, Alabama, Coosa, Tallapoosa, and Chattahoochee rivers. 


\section{FAUNAL ZONES AND SUBZONES.'}

\section{STRATIGRAPHIC RELATIONS.}

The paleontologic researches carried on in the eastern Gulf region have resulted in the differentiation of several invertebrate faunal zones and subzones in the Upper Cretaceous deposits. Named from the top downward, these are as follows:

1. The Exogyra costata zone, which embraces all the typical marine beds of the Cretaceous above the Exogyra ponderosa zone. Near the top a well-marked subzone designated the Liopistha protexta subzone is traceable through a part of the region. New faunal elements appear in extreme uppermost Cretaceous beds which locally in the region intervene between the Liopistha protexta subzone and the base of the overlying Eocene.

2. The Exogyra ponderosa zone, which is divisible into $(a)$ the part of the zone included between the Mortoniceras subzone and the base of the Exogyra costata zone, and (b) the Mortoniceras subzone.

3. The basal beds of the Eutaw formation.

The stratigraphic positions of each of these paleontologic divisions and the estimated thicknesses of strata embraced by them are shown in the generalized section (fig. 1).

\section{FOSSIL LOCALITIES.}

For convenience in discussing the distribution and ranges of the eastern Gulf Cretaceous fossils the localities from which collections have been made have been grouped into the eight areas which are roughly outlined on the sketch map (fig. 2) and which may be designated (1) western Tennessee; (2) northern Mississippi; (3) region of Houston, Pontotoc, Aberdeen, Tupelo, etc., Miss.; (4) eastcentral Mississippi and an adjacent portion of Alabama; (5) region of Warrior and Tombigbee rivers, Ala.; (6) region of Alabama River, Ala.; (7) region of Chunnenugga Ridge, etc., Ala.; (8) Chattahoochee River and Georgia.

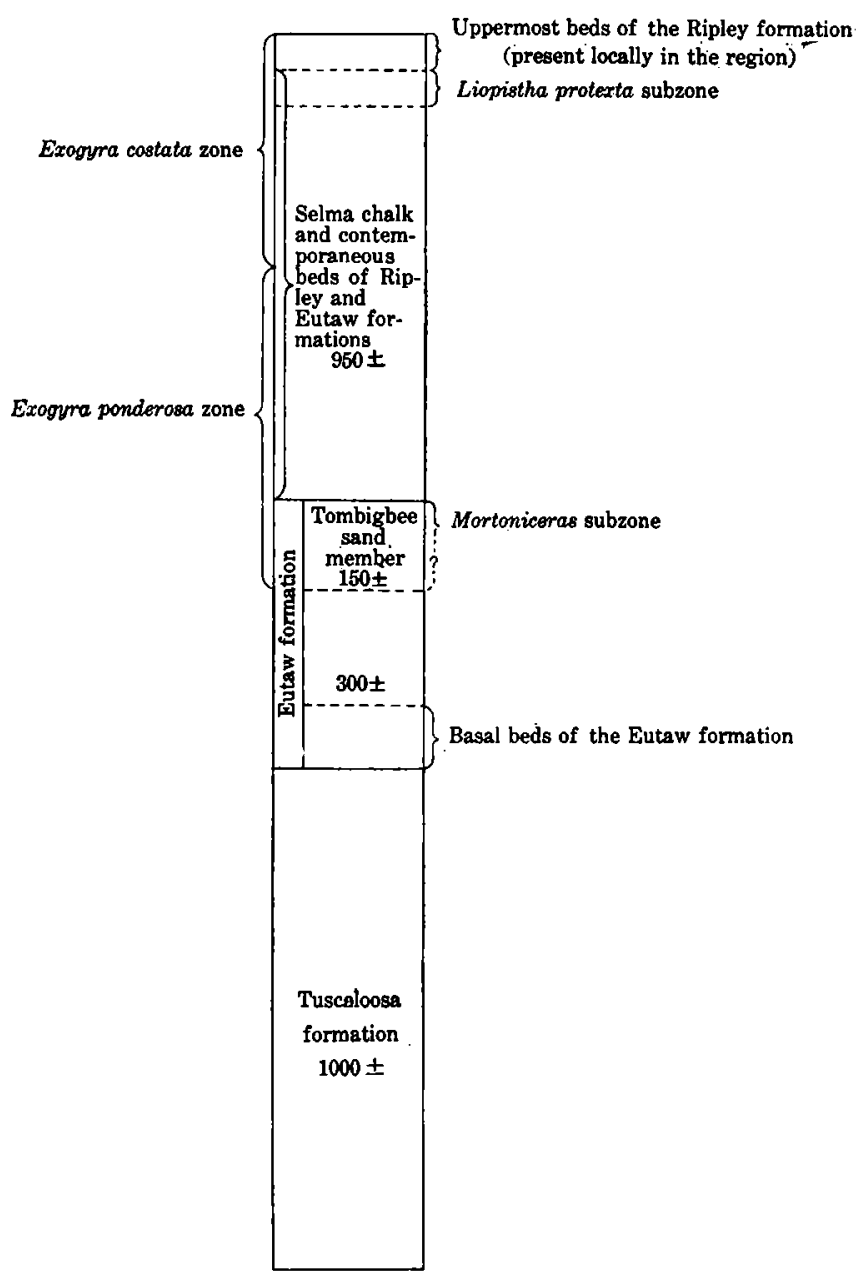

FIGURE 1.--Generalized section showing fossil zones and subzones in the eastern Gulf Upper Cretaccous deposits. In northern Mississippi and in Tennessee the top of the Eutaw formation rises to higher stratigraphic levels than in Alavama and in east-central Mississippi, and includes the time equivalents of the basal portion of the Selma chalk. Figures indicate thickness in feet. (See Pl. X, p. 20.)

\section{DISTRIBUTION AND RANGE OF THE SPECIES.}

The stratigraphic ranges of the invertebrate fossils identified from the areas just named are given in Tables 1 to 8 , inclusive. In Table 9 the ranges as given in Tables 1 to 8 are summarized, and columns are added showing the stratigraphic occurrence in the Carolinas and New Jersey of such of the eastern Gulf species as are common to those States. Comparison with the western Gulf Upper Cretaceous faunas is omitted from the table and in large part from the text discussions, because the ranges of many of the species in that region are as yet but imperfectly known. Approximate correlations are possible, but as paleontologic investigations are now being conducted by the writer in the western Gulf region he has deemed it best to postpone an attempt at exact correlation until the results of this later work are available. 
In determining the fossils and preparing the lists on which the tables are based the writer was hampered by the fact that the types of many of the species were not at hand for comparison and that he had to depend on published descriptions and illustrations. The lists must therefore

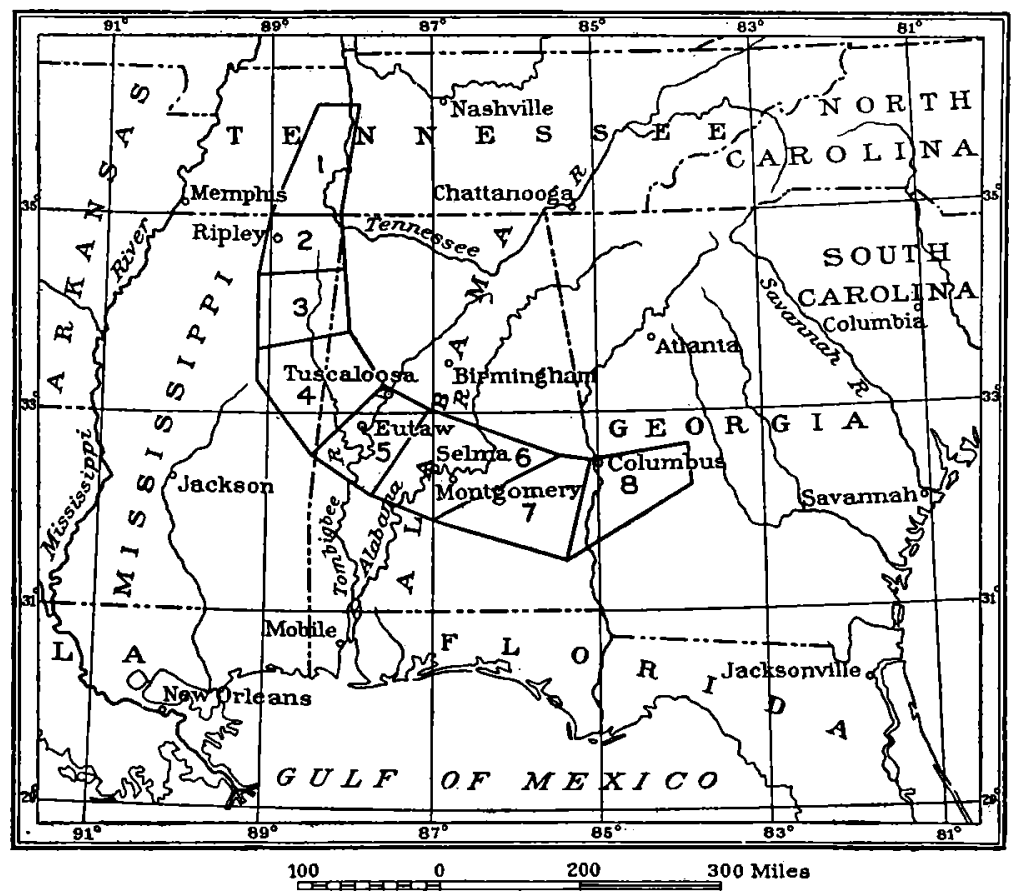

FIGURE 2.-Sketch map showing areas of paleontologic collections Iisted in Tables 1 to 8 . The numbers on the map correspond with the numbers of the tables.

be regarded as of a preliminary character. For this reason it is to be expected that the exhaustive studies of the faunas of the region soon to be undertaken will show the necessity for many changes in nomenclature and will reveal some errors in the determinations of genera and species. It is also to be expected that some species now regarded as restricted in range within certain limits will be found also at higher or lower horizons. But this lessening of the number of restricted forms will probably be offset by the discovery of new restricted forms, and by the recognition of specific differences in forms now regarded as having wide vertical ranges. It is believed, however, that such changes as are found necessary will be of minor importance as regards their effect upon the major conclusions reached through these preliminary studies. Many questionably identified species and many forms identified generically only have been omitted from the tables.

TABLE 1.-Range of Cretaceous fossils in western Tennessee. ${ }^{a}$

[Area 1 on sketch map, fig. 2.]

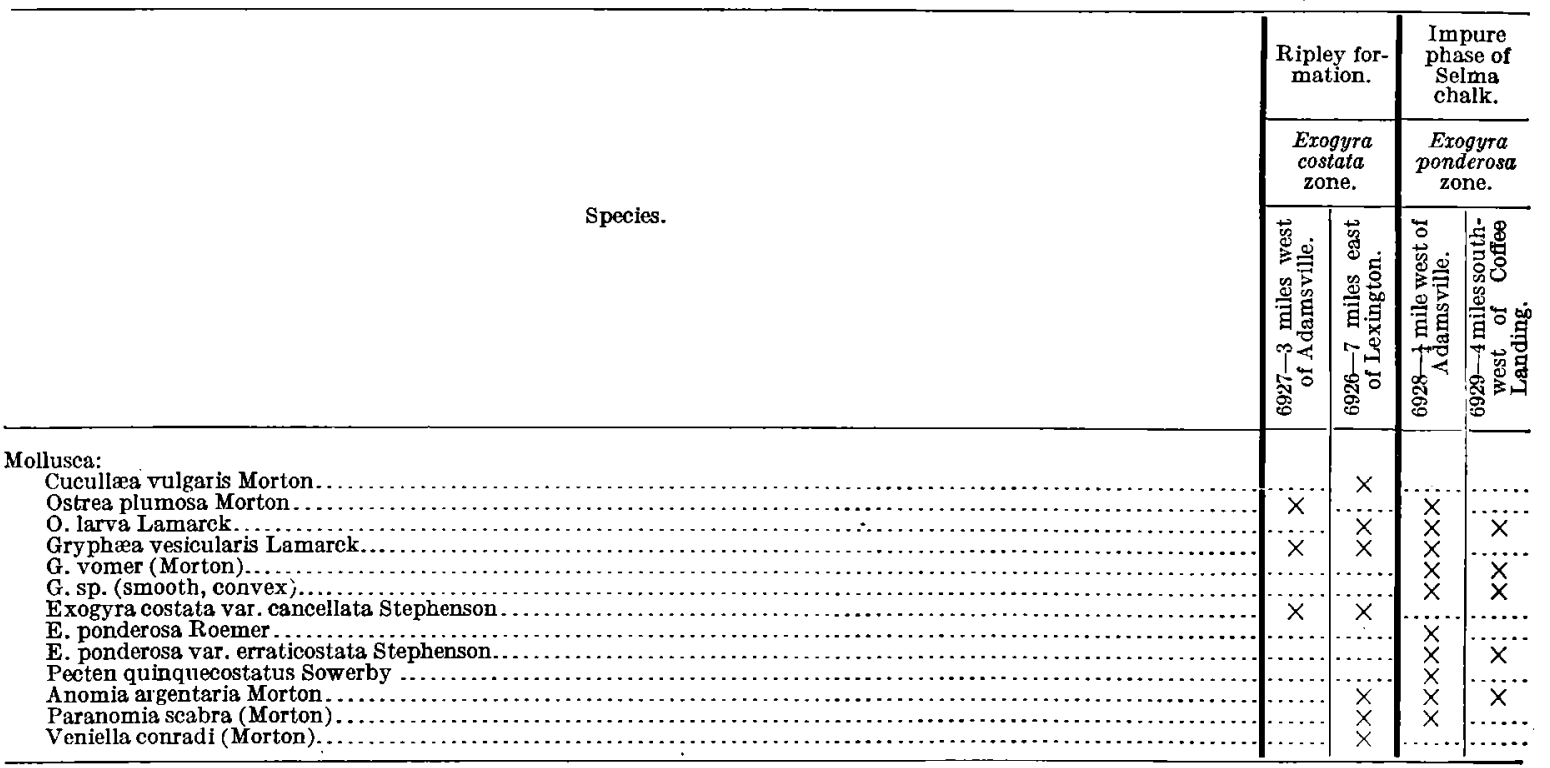

a The numbers are the collection numbers of the U. S. Geological Survey; the collections are in the U. S. National Museum. 6927. - Selmer-A damsville road, 3 miles west of A damsville, Tenn. L. W'. Stephenson, collector.

6926.-Lexington-Chesterville road, about 7 miles east of Lexington, Tenn. L. W. Stephenson, collector.

6928. - Selmer-Adamsville road, one-quarter mile west of Adamsville, Tenn. $\dot{L}$. W. Stephenson, collector.

6929. - Adamsville-Coffee Landing road. about 4 miles southwest of Coffee Landing. Tennessee River, Tenn. L. W. Stephenson, collector. 


\begin{tabular}{|c|c|c|}
\hline Ripley formation. & Samm chalak & Futar formation Trombibibere \\
\hline
\end{tabular}

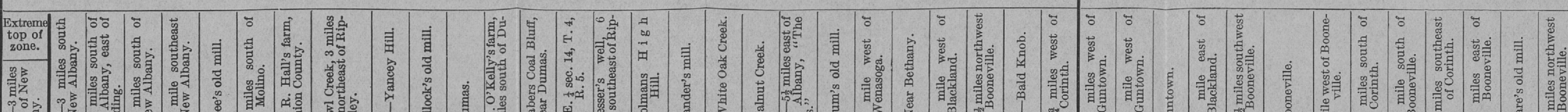

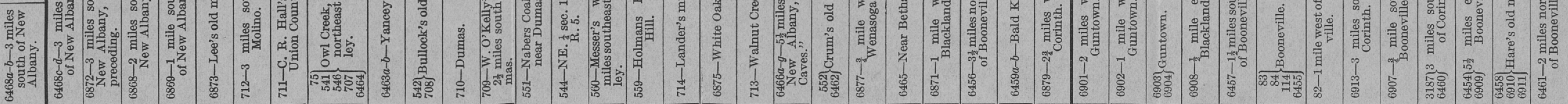

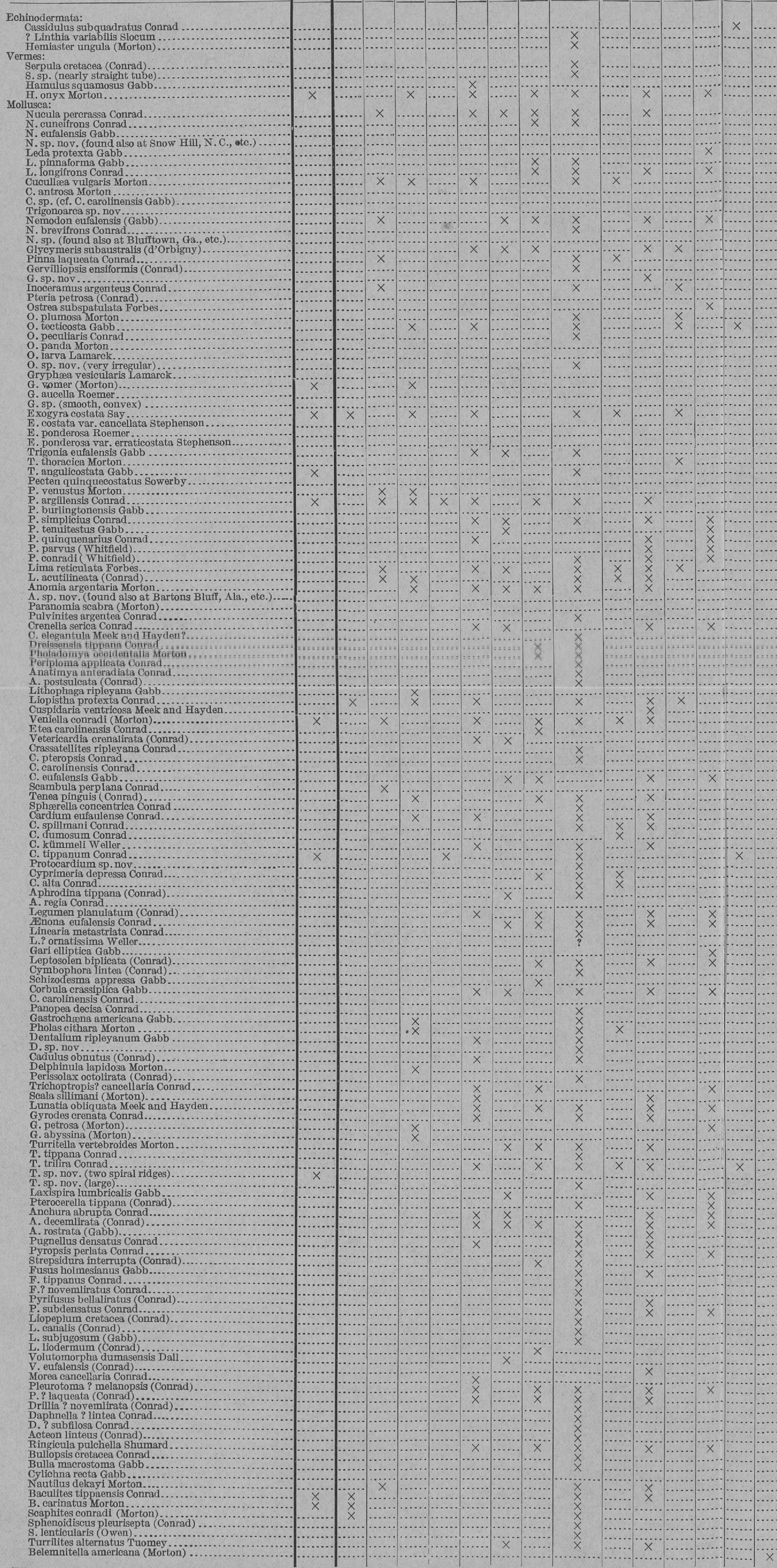

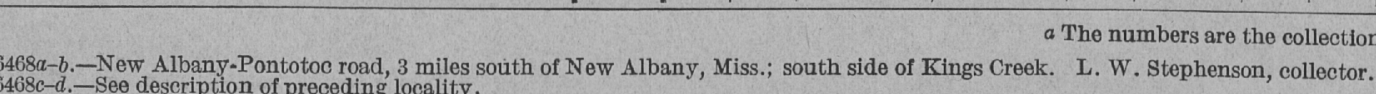

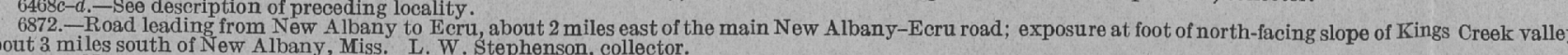

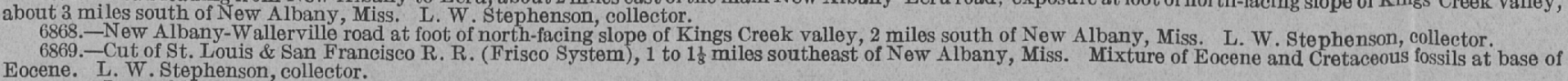

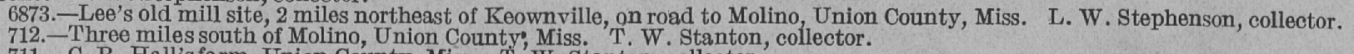

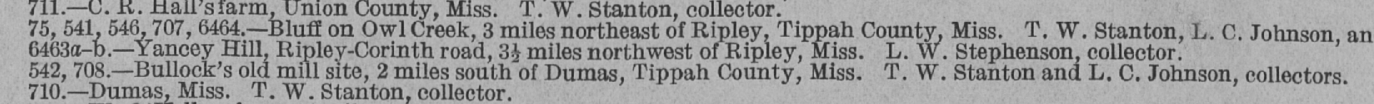

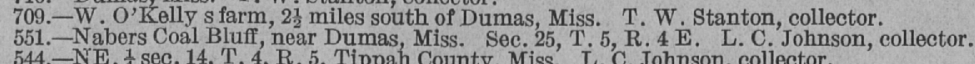

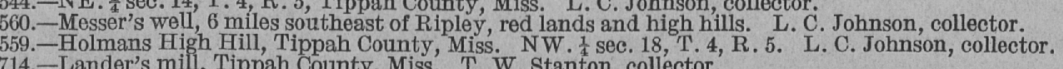

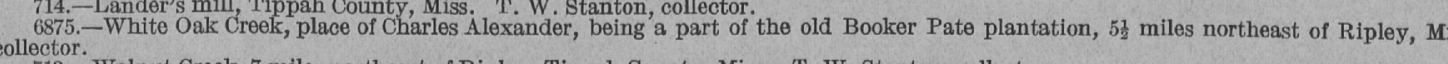

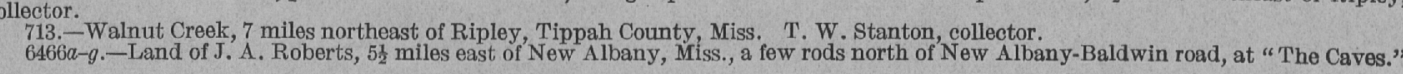
105-№. 81-14. (To face page 24.) No. 1 .

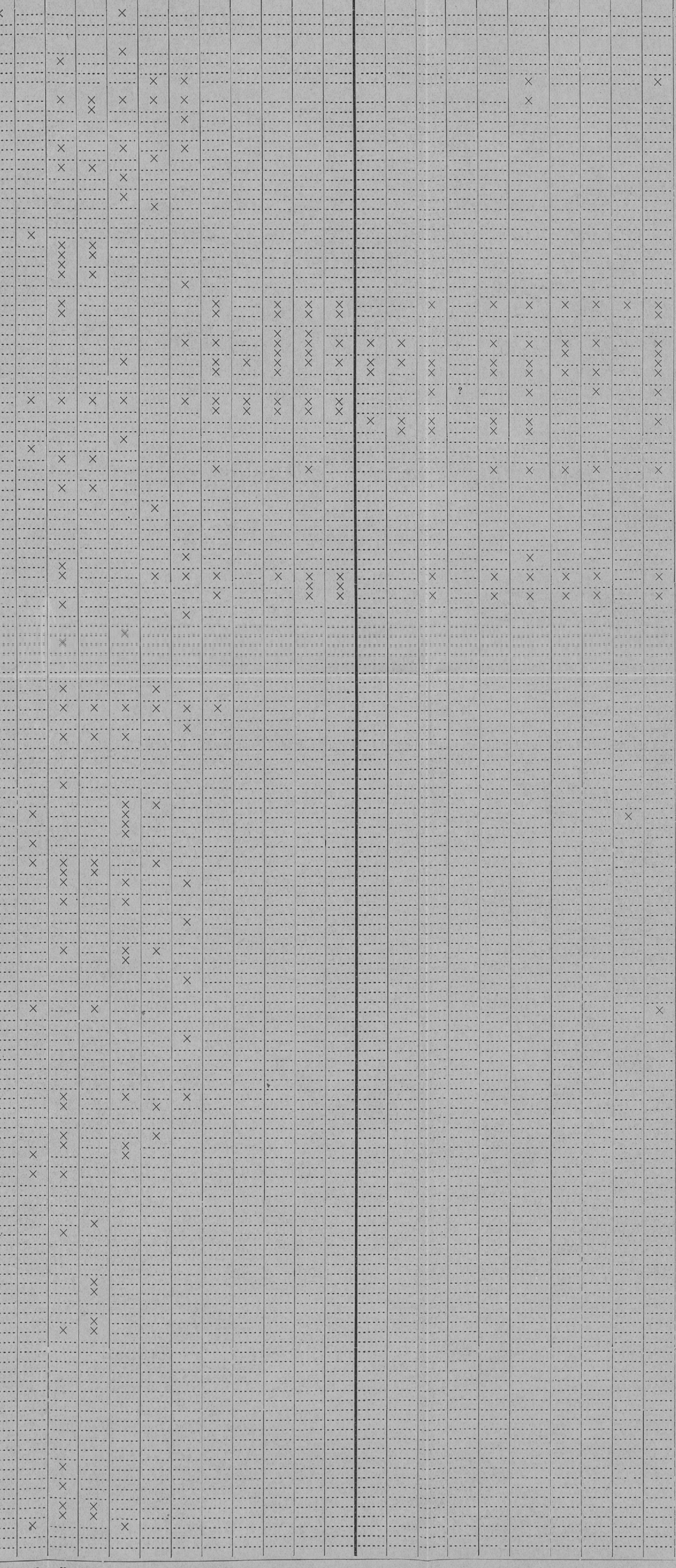

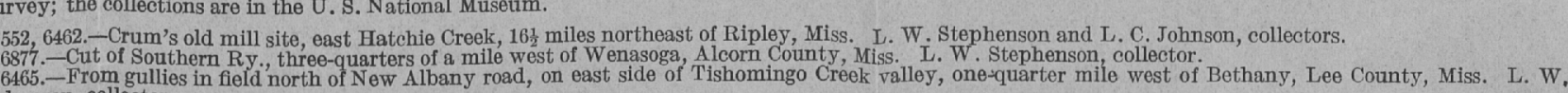

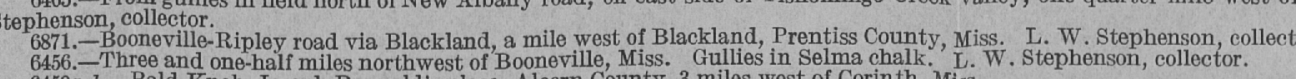

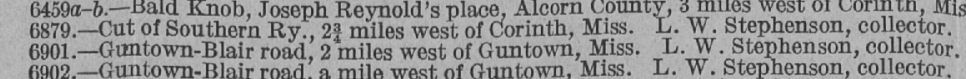

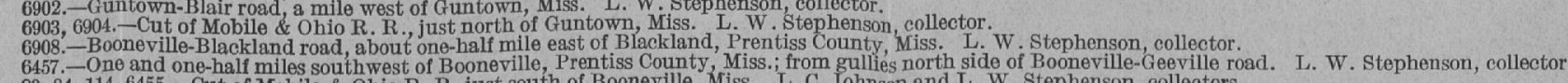

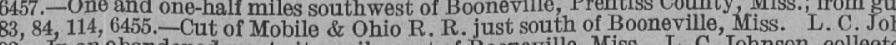

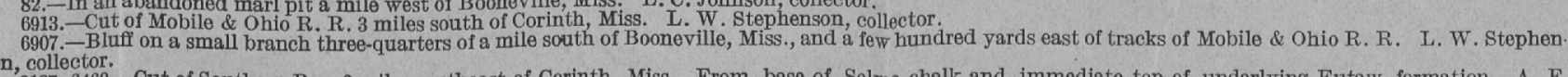

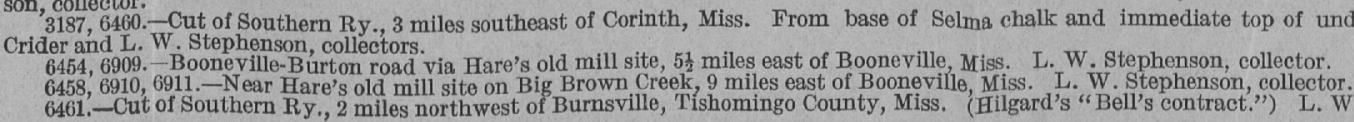





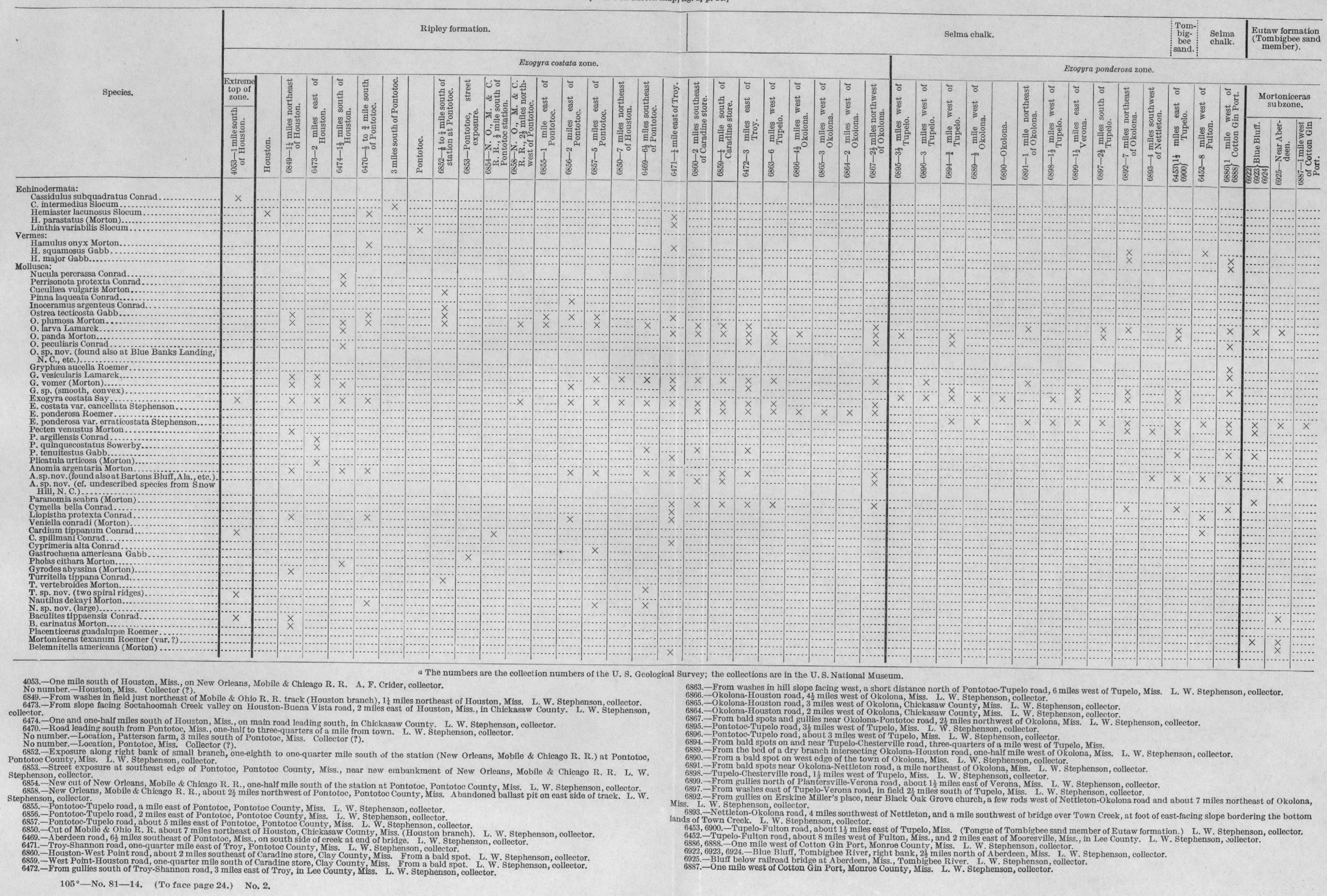




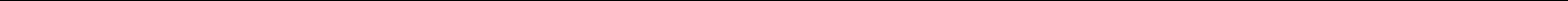


TABLE 4.-Range of Cretaceous fossils, east-central Mississippi and an adjacent portion of Alabama.a Area 4 on sketeh map, fig. 2, p. 24

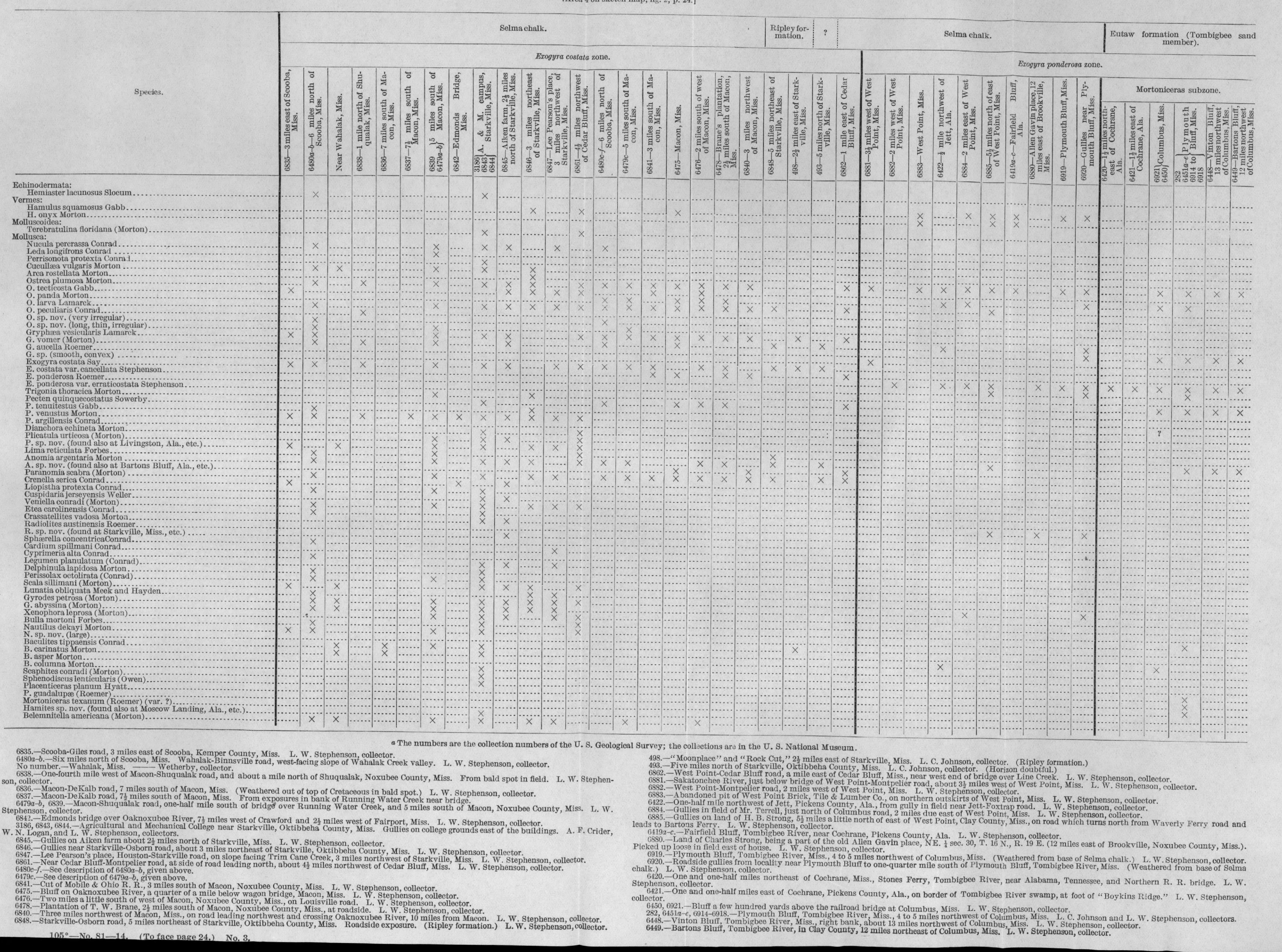


TABLE 5.-Range of Cretaceous fossils, region of Warrior and Tombigbee rivers, Ala.e

[Area 5 on sketch map, fig. 2, p. 24.]

Selma chalk.

Eutaw formation (Tombigbee sand member).

\begin{tabular}{|c|c|c|c|c|c|c|c|c|c|c|c|c|c|c|c|c|c|c|c|c|c|c|c|c|c|c|c|c|c|c|}
\hline \multicolumn{26}{|c|}{ Selma chalk. } & \multicolumn{5}{|c|}{ Eutaw formation (Tombigbee sand member). } \\
\hline \multicolumn{18}{|c|}{ Exogyra costata zone. } & \multicolumn{13}{|c|}{ Exogyra ponderosa zone. } \\
\hline \multirow[b]{3}{*}{ 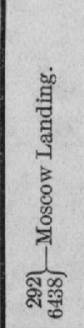 } & \multirow{3}{*}{ 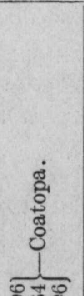 } & \multirow{3}{*}{ 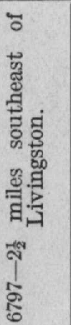 } & \multirow{3}{*}{ 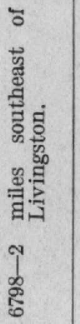 } & \multirow[b]{3}{*}{ 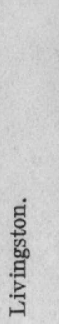 } & \multirow{3}{*}{ 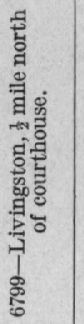 } & \multirow{3}{*}{ 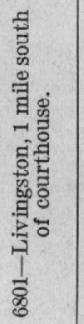 } & \multirow{3}{*}{ 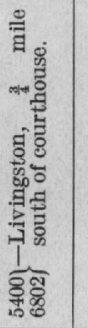 } & \multirow{3}{*}{ 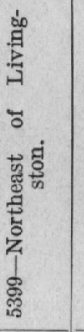 } & \multirow{3}{*}{ 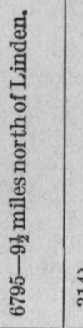 } & \multirow{3}{*}{ 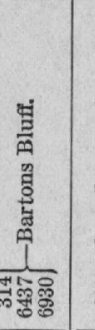 } & \multirow{3}{*}{ 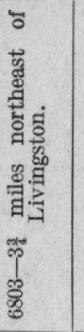 } & \multirow{3}{*}{ 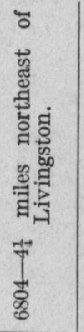 } & \multirow{3}{*}{ 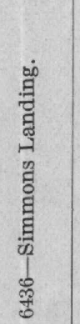 } & \multirow{3}{*}{ 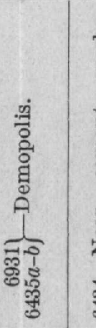 } & \multirow{3}{*}{ 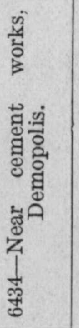 } & \multirow{3}{*}{ 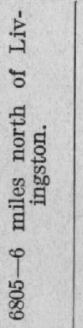 } & \multirow{3}{*}{ 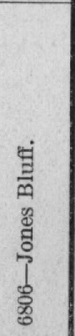 } & \multirow{3}{*}{ 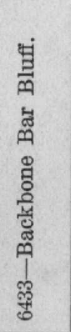 } & \multirow{3}{*}{ 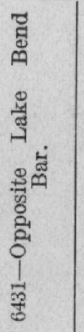 } & \multirow{3}{*}{ 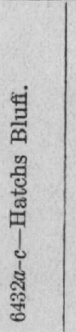 } & \multirow{3}{*}{ 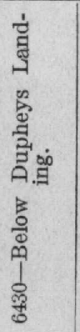 } & \multirow{3}{*}{ 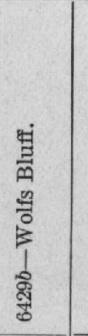 } & \multirow{3}{*}{ 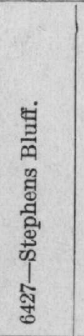 } & \multirow{3}{*}{ 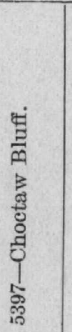 } & \multirow{3}{*}{ 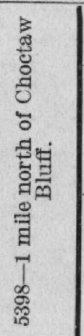 } & \multicolumn{5}{|c|}{ Mortoniceras subzone. } \\
\hline & & & & & & & & & & & & & & & & & & & & & & & & & & $\begin{array}{c}\text { Base of Selma } \\
\text { chalk or top } \\
\text { of topa } \\
\text { formation. } \\
\text { form. }\end{array}$ & $\frac{\mathrm{g}}{\mathrm{m}}$ & 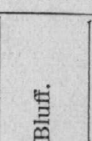 & כே甘 & \\
\hline & & & & & & & & & & & & & & & & & & & & & & & & & & 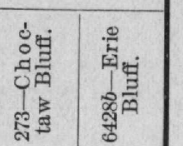 & 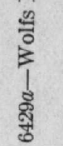 & 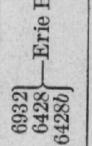 & 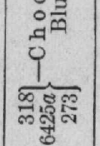 & \\
\hline
\end{tabular}

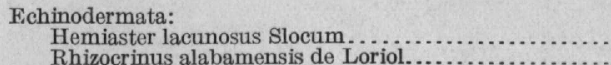

Vermes:

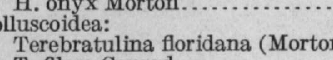

Molluscea: Cosara vulad............
Cucullea vuris Morton
Ostrea plumosa Morton...

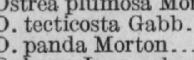

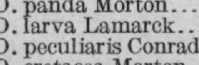

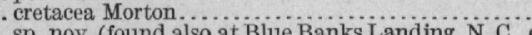
o. sp. nov. (Very irregular)

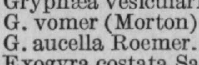

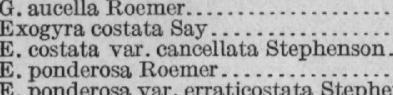

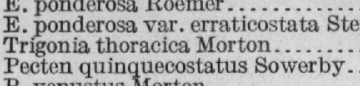

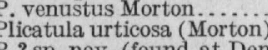

ot Demopoilis, Alia., ete.)

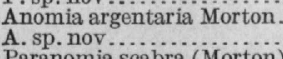

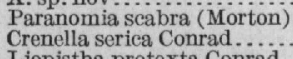

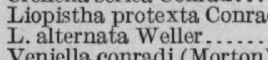

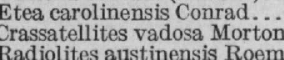

Cardiume dumbonsums Conradi.
Legumen planulatum (Corrad

Corbula carolinensis Conrad.......

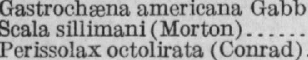

Gyrodes petrosian (Morton)...

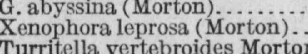

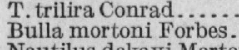

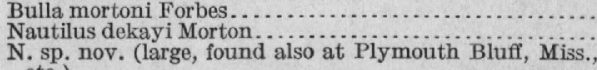

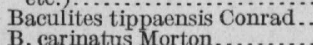

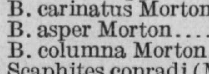

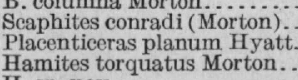

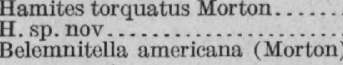

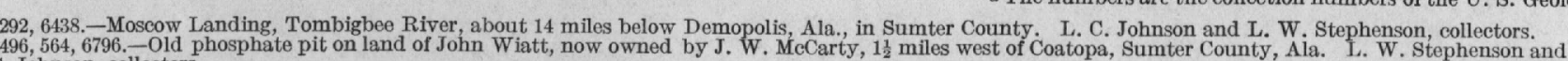

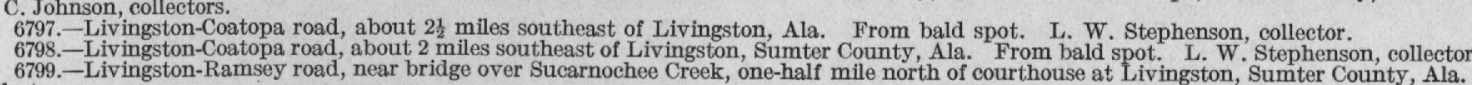

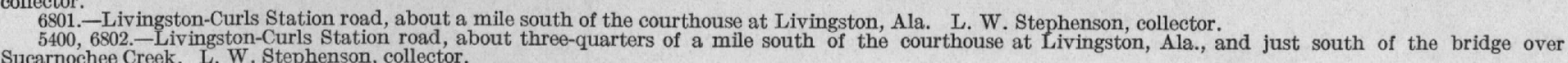

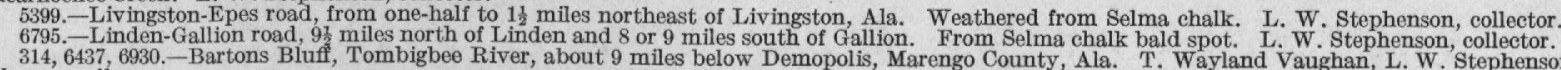

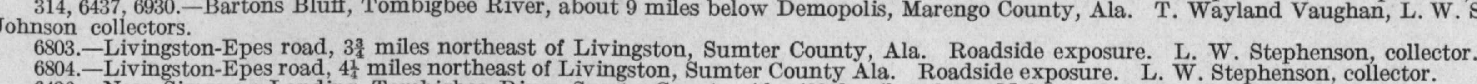

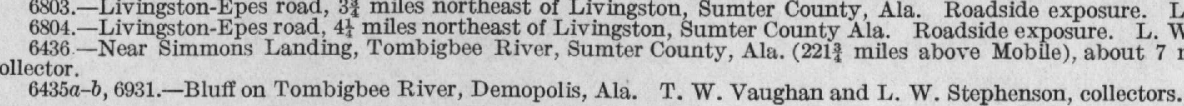
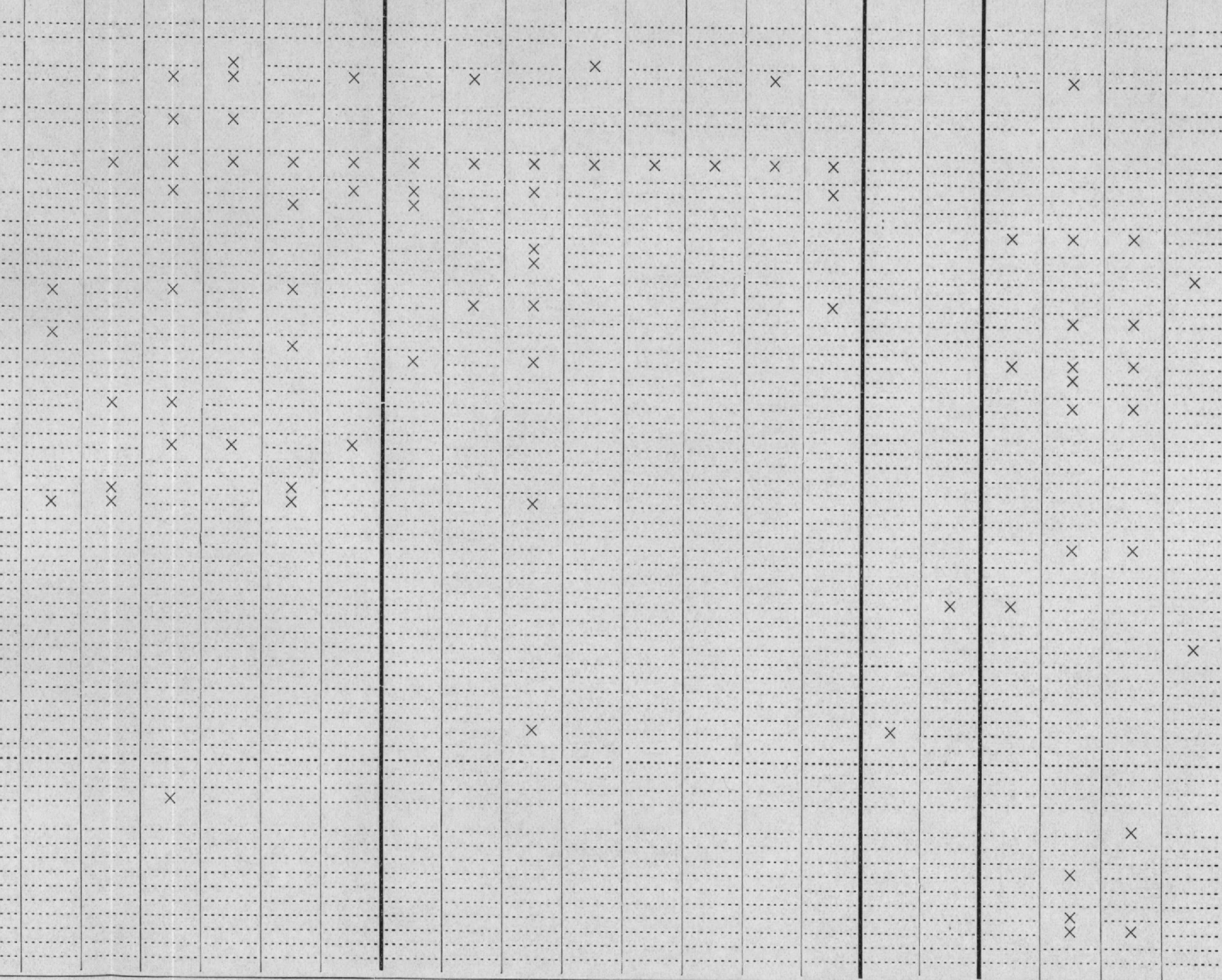

$105^{\circ}-$ No. $81-14$. (To face page 24.) No. 4

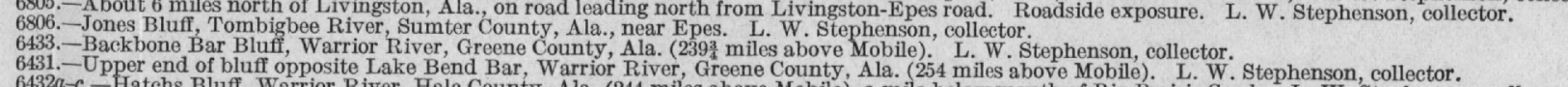

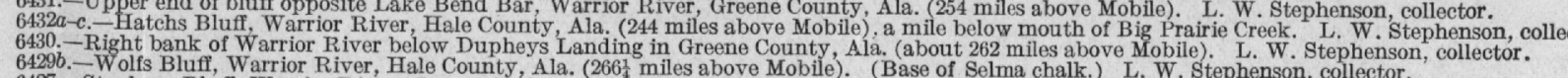

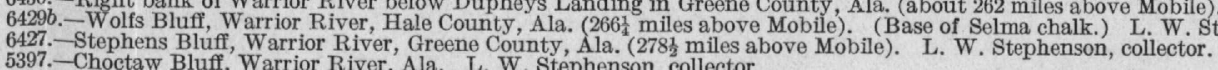

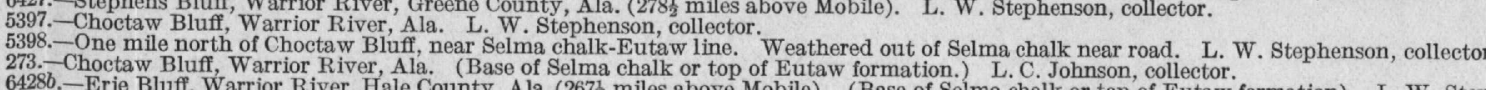



TABLE 6. - Range of Cretaceous fossils, region of Alabama River, Ala.a

[Area 6 on sketch map, fig. 2, p. 24.]

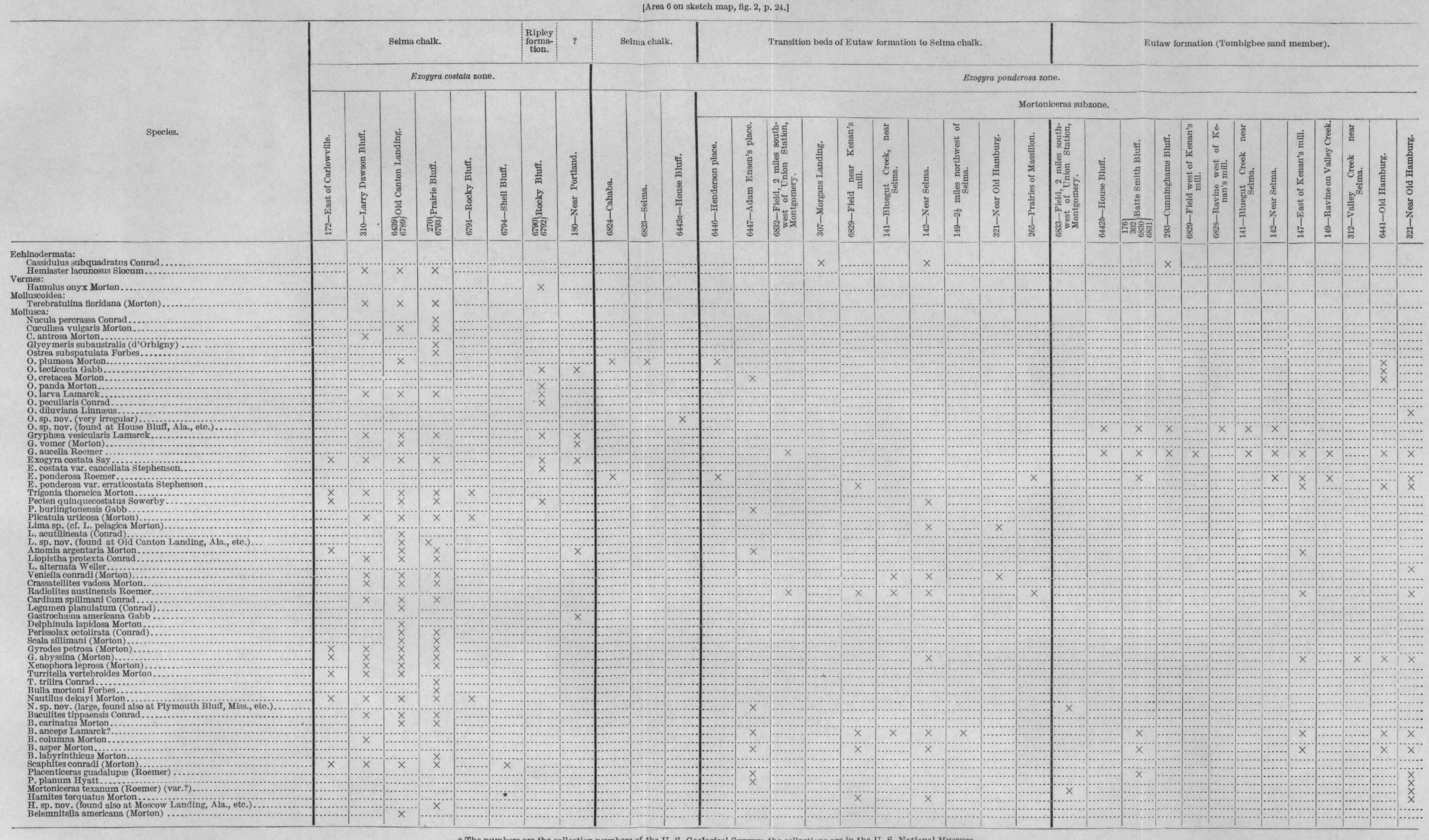

$a$ The numbers aro the collection numbers of the U. S. Geologi

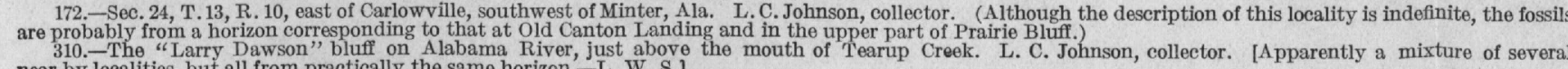
6439, 6789. - Alabama River, old Cant ton Landing, Wilcox County, Ala, about 14 miles bolow the mouth of Pine Barren Creek. L. W. Stephenson, collector.

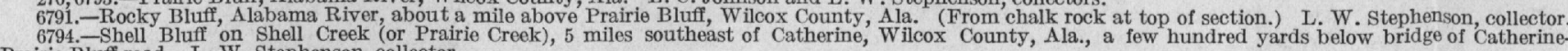

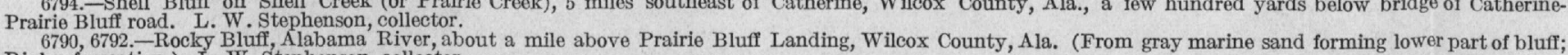

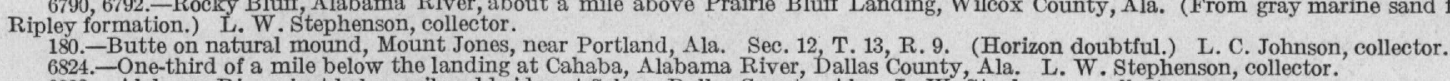
(From base of Selma chalk.) L. W. Stephenson, colloctor.

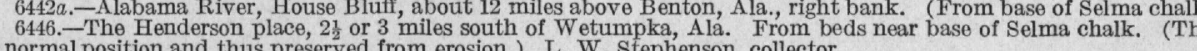

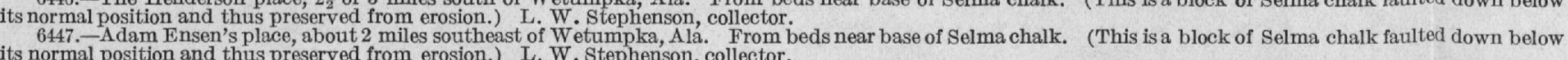

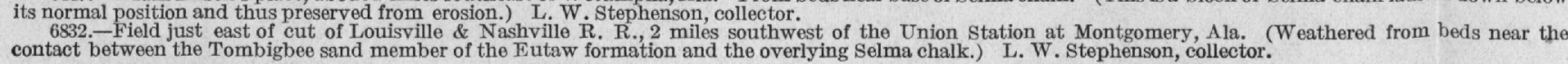
$105^{\circ}$-No. 81-14. (To face page 24.) No. 5 .

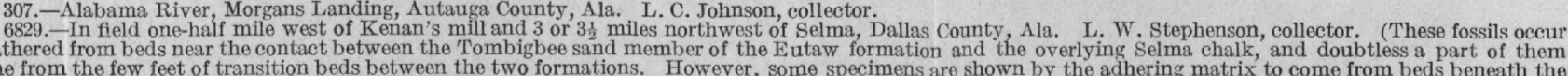

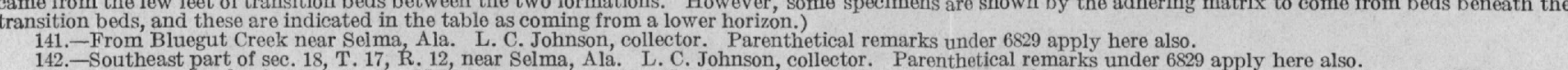

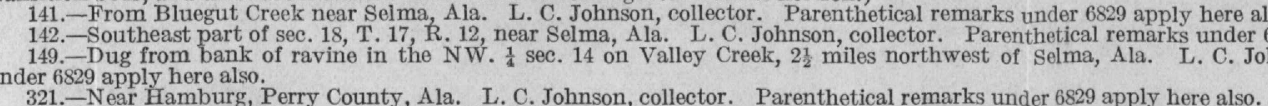

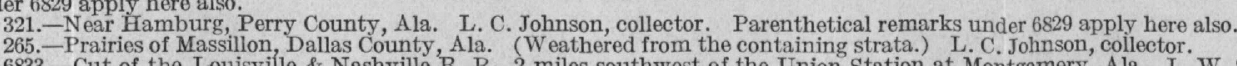

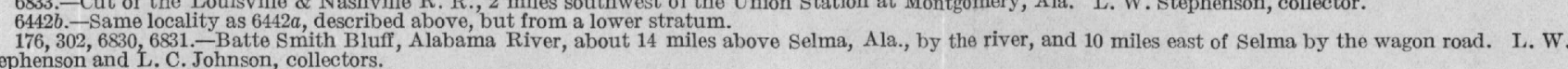

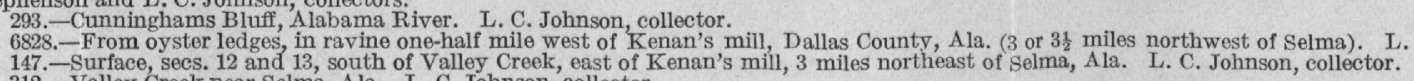

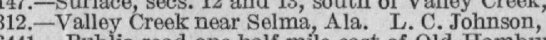




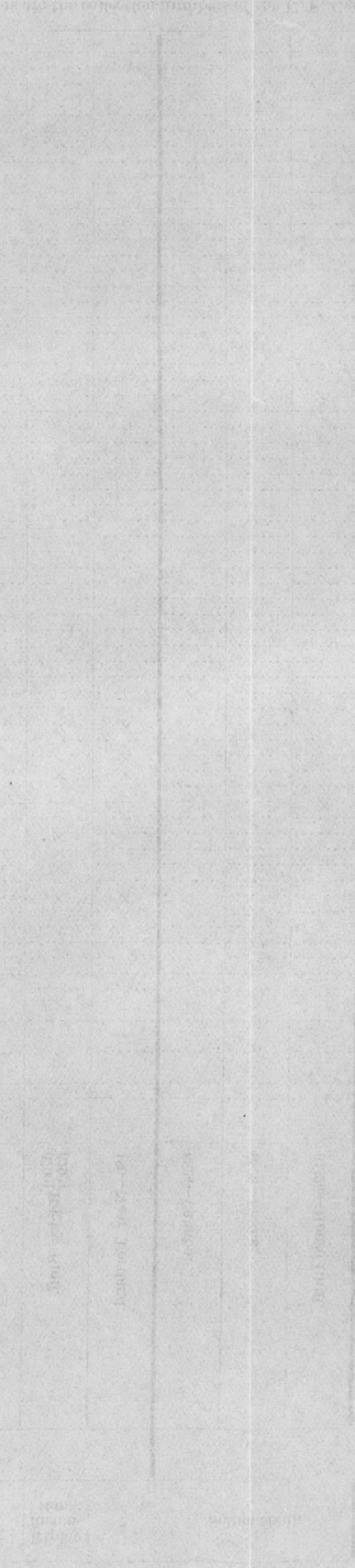


TABLE 7.-Range of Cretaceous fossils in the region of Chunnenugga Ridge, etc., Ala.a

[Area 7 on sketch map, fig. 2, p. 24.]

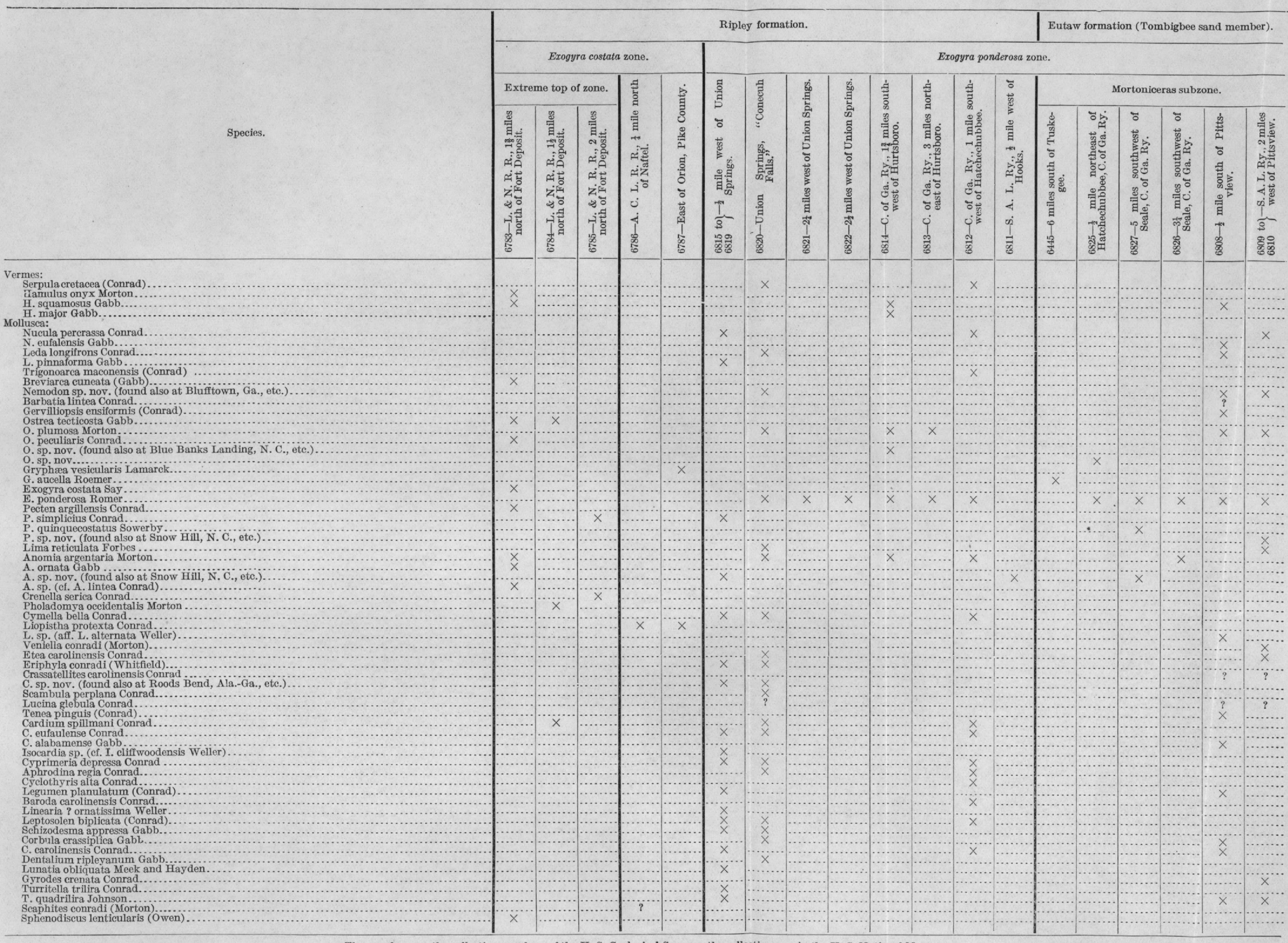

$a$ The numbers are the collection numbers of the U. S. Geological Survey; the collections are in the U. S. National Museum.

6783.-Cut of Louisville \& Nashville R. R. $1 \frac{3}{8}$ miles north of Fort Deposit, Lowndes County, Ala. L. W. Stephenson,

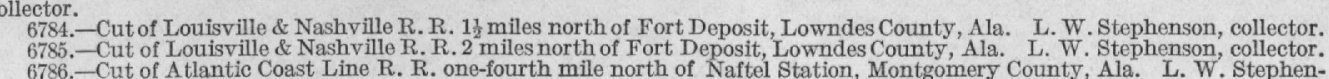

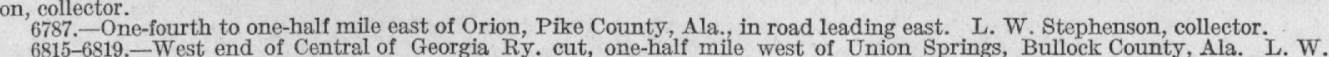
6815-6819. - West end of Central of Georgia Ry. cut, one-half mile west of Union Springs, Bullock County, Ala. L. W.
.

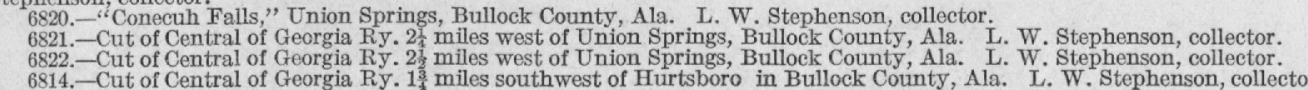
$105^{\circ}$-No. 81-14. (To face page 24.) No. 6 .

6813. Cut of Central of Georgi RV. 3 miles northeast of Hurtsboro, Russell County, Ala. L. W. Stephenson, collector,

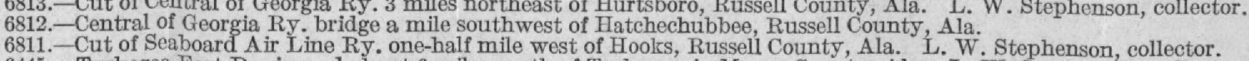

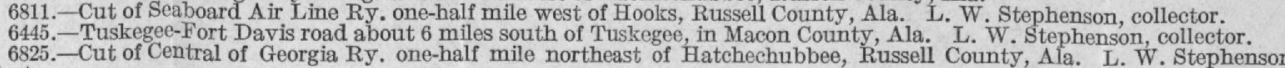
6827.-Cut of Central of Georgia Ry. 5 miles southwest of Seale, Russell County, Ala. (25th milepost from Columbus, Ga.). L. W. Stephenson, collector.
6826. - Cut of Central of Georgia Ry. 31 miles southwest of Seale, Russell County, Ala. L. W. Stephenson, collector.
6808.- Wagon bridge over Hatchechubbee Creek one-half mile south of Pittsview, Russeli County, Ala. L. W. Stephenson,

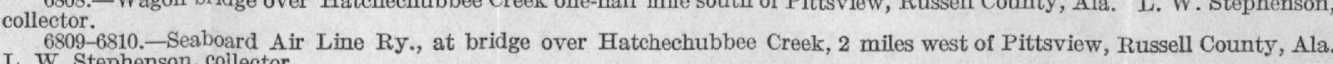




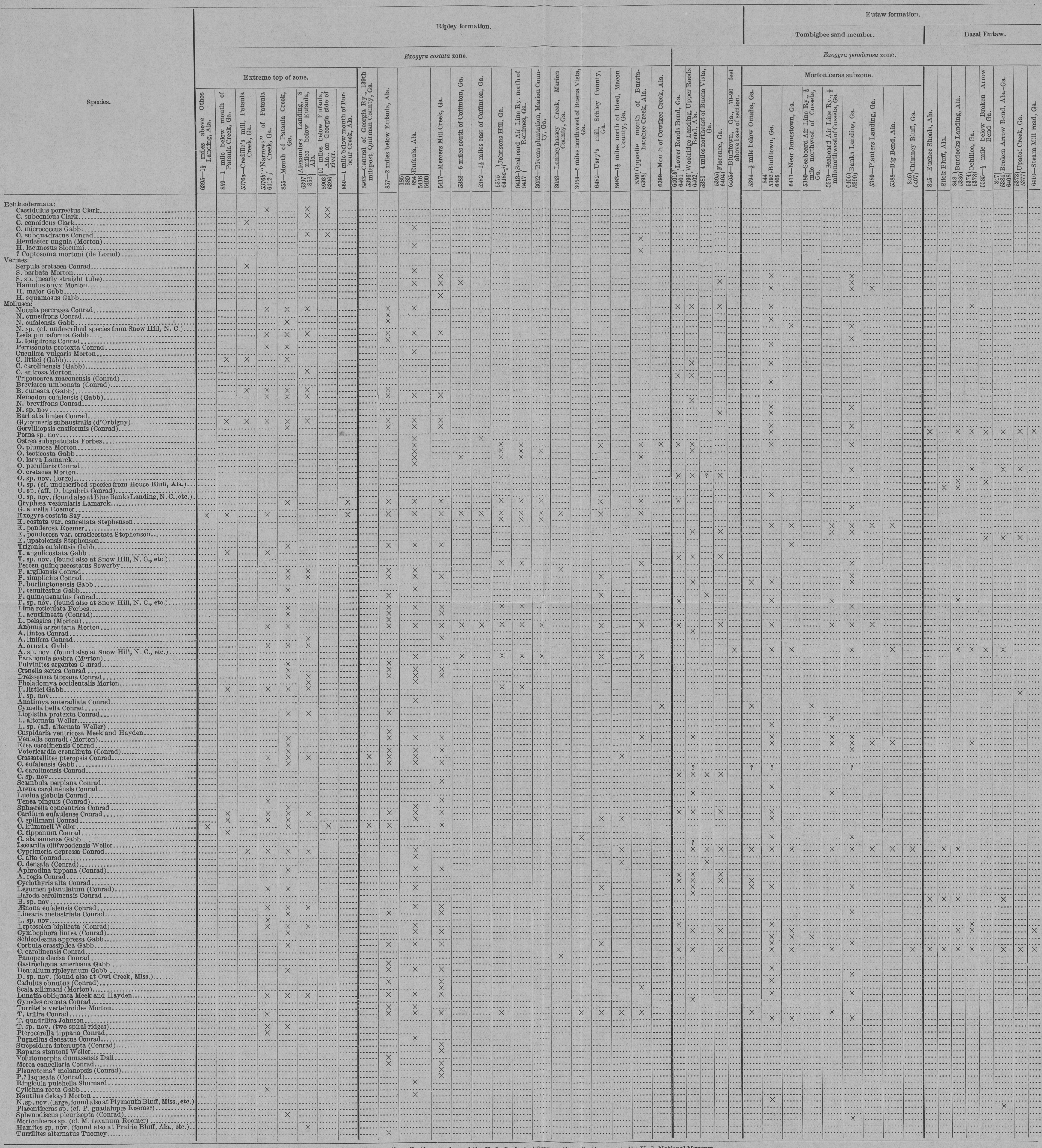

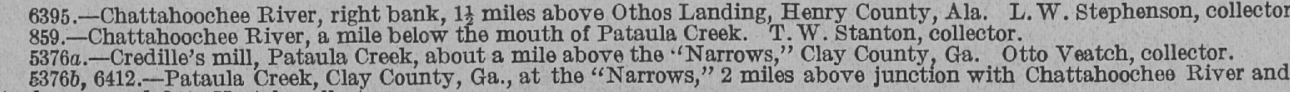
9 miles north of Fort Gaines. I. IT.

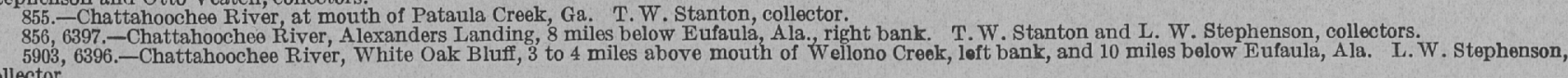

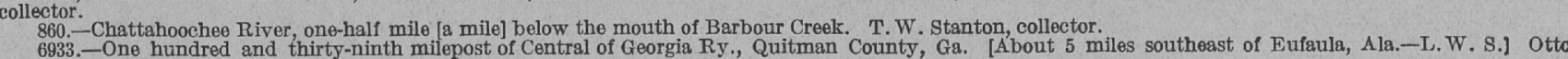

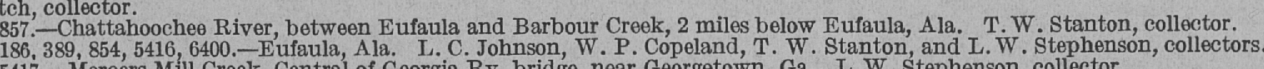

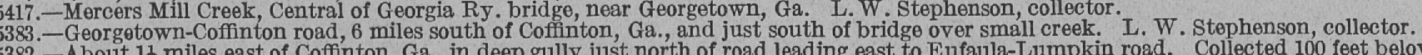

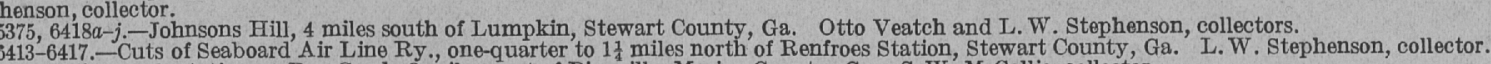

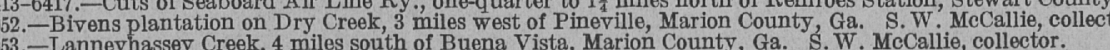

wollector.

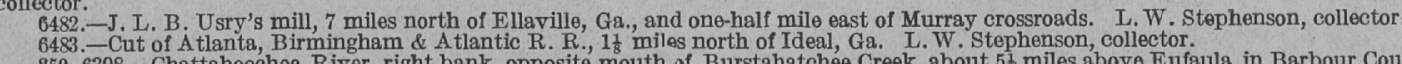

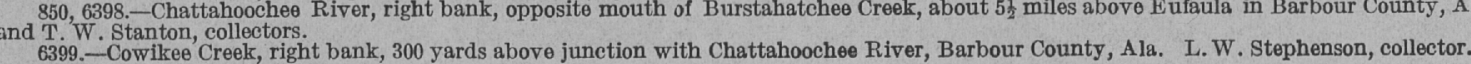
$105^{\circ}$-No. 81-14. (To face page 24.) No. 7 .

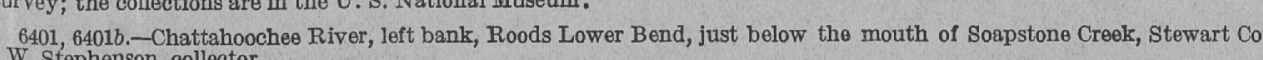

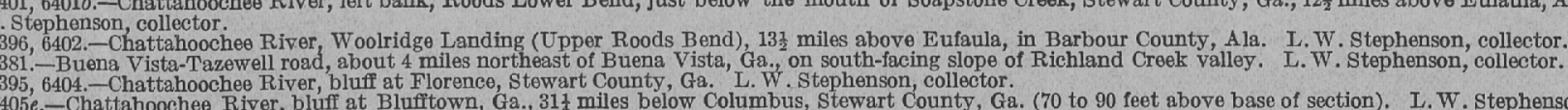

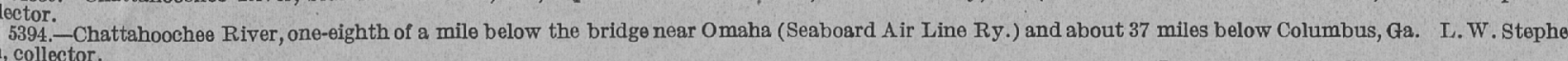

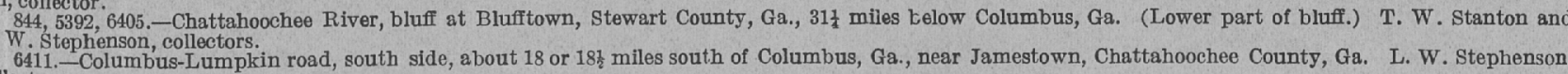

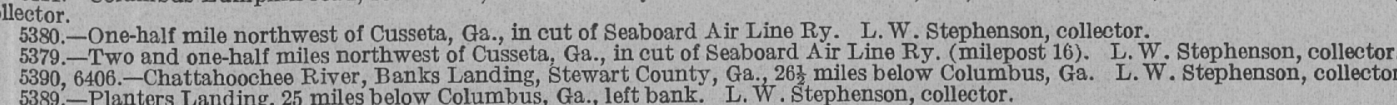

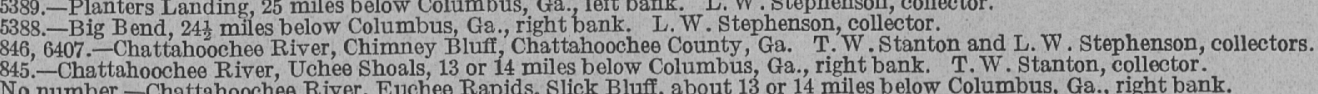

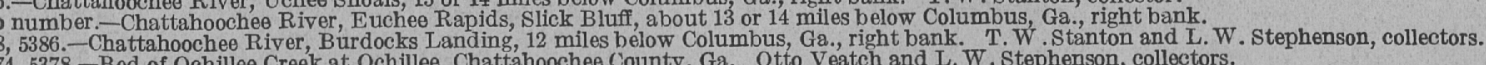

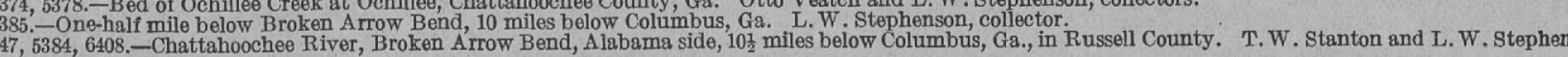

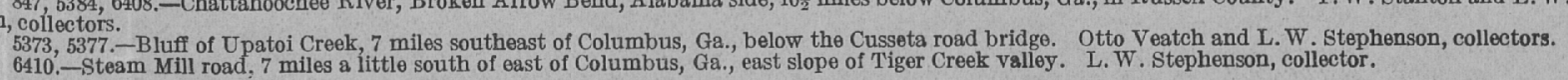





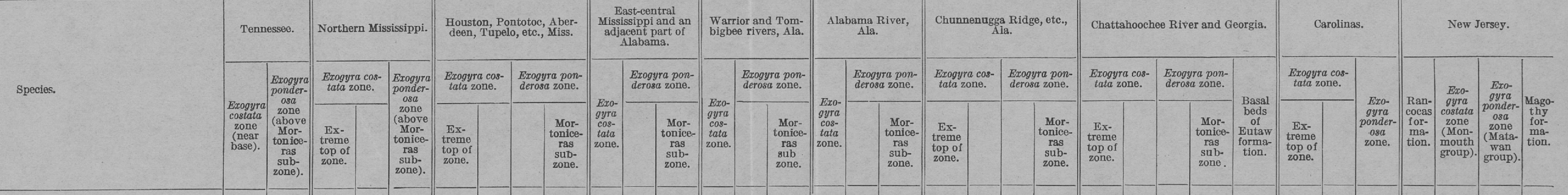

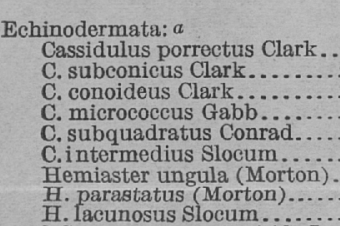

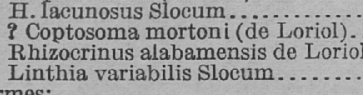

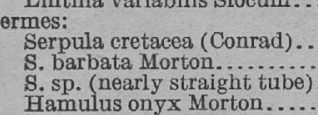

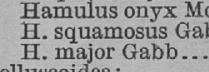

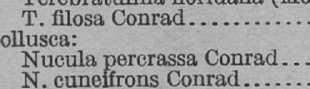

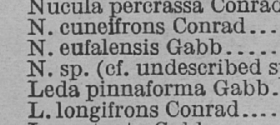

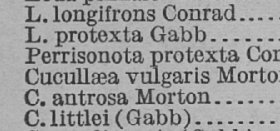

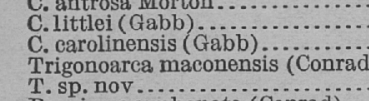

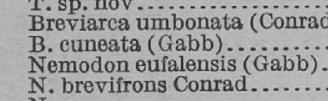

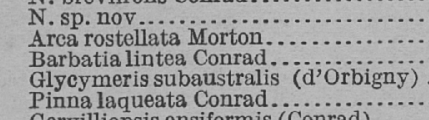

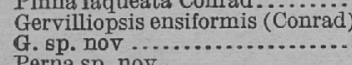

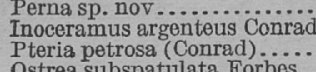

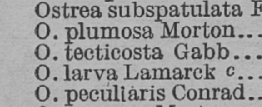

a.t.

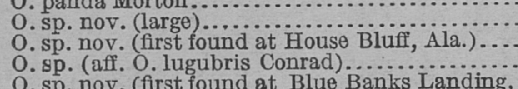

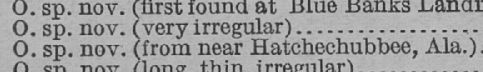

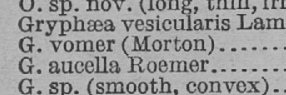

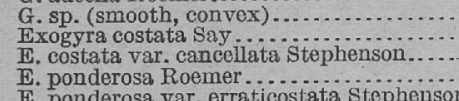

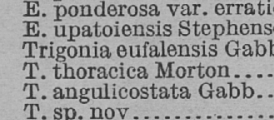

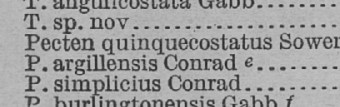

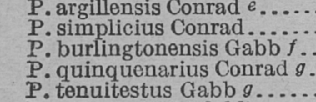

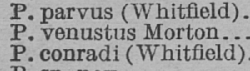

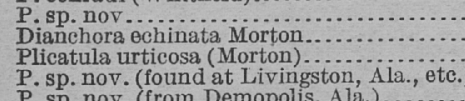

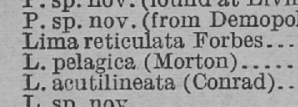

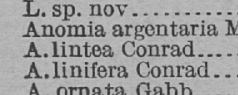

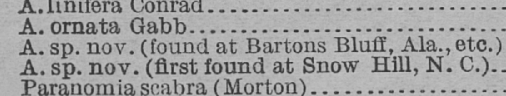

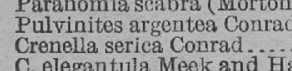

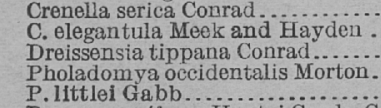

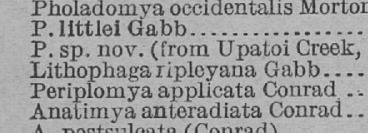

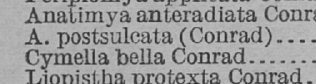

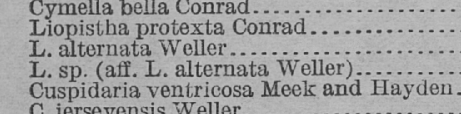

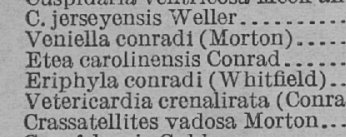

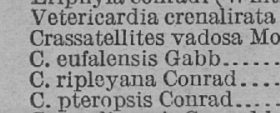

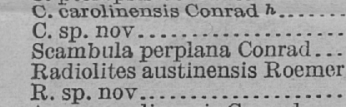

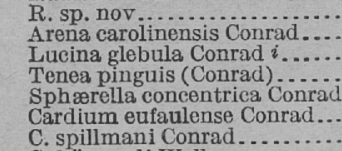

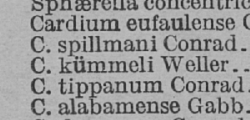

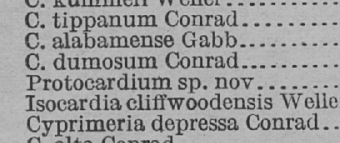

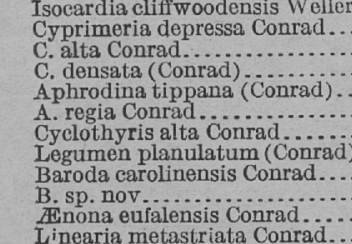

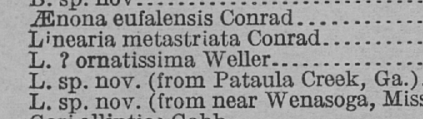

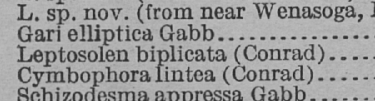

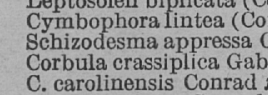

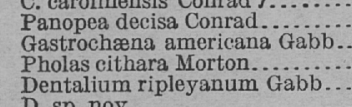

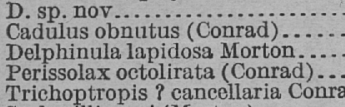

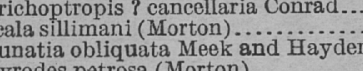

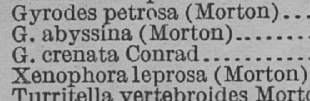

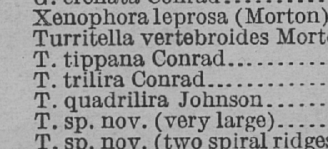

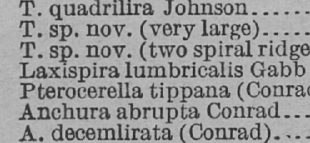

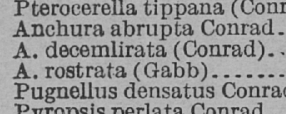

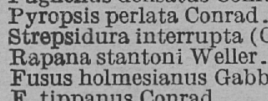

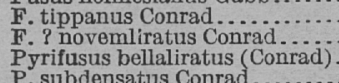

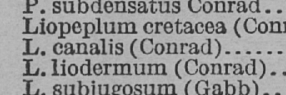

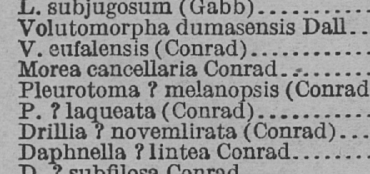

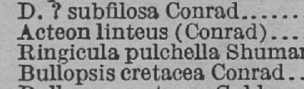

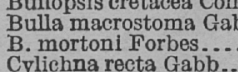

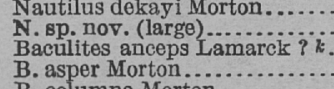

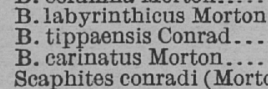

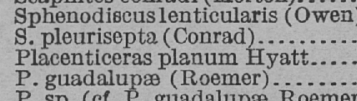

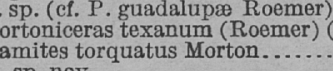



BASAL BEDS OF THE EUTAW FORMATION.

Sixteen species have been determined from the basal 100 or 150 feet of the Eutaw formation in the Chattahoochee region, and a few poorly preserved specimens, including Ostrea, Gryphæa, Pecten, and Cardium, have been found at and near the base of the formation on Alabama River north of Montgomery. Except for these no invertebrates are known in the basal beds of the Eutaw of the eastern Gulf region.

RANGE OF THE SPECIES.

The 16 species identified from the basal beds of the Eutaw formation in the ('hattahoochee region are as follows: ${ }^{1}$

Fossils from basal beds of the Eutaw formation.

Mollusca:

Nucula percrassa Conrad. a $b e d$.

Perna sp. nov. $c d$.

Ostrea cretacea Morton. $c d$.

O. sp. nov.? (cf. undescribed species from House Bluff, Alabama River, Ala.). $c d$ ?

O. sp. (aff. O. lugubris Conrad). $d$.

Exogyra upatoiensis Stephenson. $d$.

Pecten sp. nov. $c d$.

Anomia sp. nov. (also found at Snow Hill, N. C., etc.).

$b c d$.

Mollusca-Continued.

Pholadomya sp. nov. $d$.

Etea carolinensis Conrad. $a b c d$.

Cyprimeria depressa Conrad. $a b c d$.

Baroda sp. nov. $d$.

I stosolen biplicata (Conrad). $a b c d$.

Cymbophora lintea (Conrad). $a b c d$.

Corbula carolinensis Conrad. $b c d$.

Placenticeras sp. (aff. P. guadalupæ Roemer). d.

Of the 16 species listed 5 are restricted to the basal beds of the Eutaw; 10, or questionably 11 , range upward into the Mortoniceras subzone. Of these last, 7 continue above the Mortoniceras subzone into the upper part of the Exogyra ponderosa zone; and 5 of these range on upward into the Exogyra costata zone. None of the 5 restricted species are known from surface outcrops in the Carolinas or in New Jersey. However, one of them, Exogyra upatoiensis Stephenson, has been recognized recently in a well sample obtained from the depths 1,974 to 2,007 feet in a well boring at Charleston, S. C., and in the same sample was found an oyster related to Ostrea lugubris Conrad, but differing slightly from the similarly related oyster found in the basal beds of the Eutaw in the Chattahoochee region.

CORRELATION.

Invertebrates.-The 5 forms restricted to the basal beds of the Eutaw formation are all new to science and therefore afford but little positive evidence as to the age of the terrane. However, the beds in which they are found are known to occupy a position stratigraphically lower than any other marine invertebrate-bearing beds thus far discovered in the eastern Gulf region, and for this reason, if for no other, the fauna must be regarded as the oldest of its kind known in the region. The new species Exogyra upatoiensis Stephenson, which occurs in the marine beds near the base of the formation, has a markedly different surface sculpture from the other known species of this genus in the Atlantic and eastern Gulf Cretaceous. (See Pl. XIII, figs. 1-4.) The presence of this species and of the fluted oyster related to Ostrea lugubris Conrad which ocmirs in the Eagle Ford shale of Texas may perhaps be considered paleontologic evidence of the greater age of this fauna. As the conditions for the preservation of one species of oyster are as favorable as they are for the preservation of any other species of the same family, this new species of Exogyra and the fluted oyster would be expected to appear in the collections from the overlying Tombigbee sand member if, in this region, they had lived contemporaneously with the oyster Exogyra ponderosa Roemer, which is common in that member.

From the range determinations as stated, the following conclusions have been deduced: (1) The invertebrate fauna present in the basal beds of the Eutaw formation possesses elements in common with Cretaceous faunas of higher horizons in the same region; however, in passing

1 The range of the species is shown by the letters appended: $a$, Exogyra costata zone; $b$, Exogyra ponderosa zone above the Mortoniceras subzone; c, Mortoniceras subzone; $d$, basal beds of Eutaw formation. 
from this basal horizon to the successively higher horizons the number of common species diminishes. (2) Although showing this relationship the fauna contains elements distinct from anything known at higher horizons. (3) It bears about the same relationship to the invertebrate fauna present in the upper part of the Black Creek formation of the Carolinas that it does to the fauna of the basal beds of the Ripley formation (part of Exogyra ponderosa zone between the Mortoniceras subzone and the Exogyra costata zone) in the Chattahoochee region. The basal beds of the Eutaw formation are therefore stratigraphically lower than the invertebratebearing beds of the Black Creek formation and, in the opinion of the writer, correspond approximately to basal noninvertebrate-bearing beds of that formation. (4) The basal beds of the Eutaw are represented at Charleston, S. C., by beds penetrated in a well boring between the depths 1,974 and 2,007 feet, which in turn probably represent the basal beds of the Black Creek formation of the Carolinas. (5) The actual evidence for a comparison of the basal Eutaw fauna with the Cretaceous faunas of New Jersey is slight, but combined with evidence furnished by the faunas from overlying horizons there seems to be sufficient grounds for correlating the containing strata approximately with the Magothy formation.

To the west, in Alabama and Mississippi, the invertebrate-bearing basal beds of the Eutaw of the Chattahoochee region are represented by corresponding basal Eutaw strata in which no well-preserved invertebrates have as yet been discovered.

Plants.-Fossil plants have been obtained at several horizons in that part of the Eutaw formation below the Tombigbee sand member (Mortoniceras subzone). E. W. Berry, who studied them, recognized 27 species. He gives the following statement of his views on the significance of the plant remains in correlation: ${ }^{1}$

It is clear that the flora of the Eutaw formation of Georgia is of approximately the same age as the MagothyMatawan flora of the northern Coastal Plain and the Black Creek flora of the Carolinas. It has much in common with the much more extensive Tuscaloosa flora of western Alabama, but is probably younger than the bulk of the Tuscaloosa flora or that found in the Middendorf arkose member of the Black Creek formation.

The evidence furnished by the plants as interpreted by Berry is in essential agreement with that afforded by the invertebrates.

The Coffee sand member of the Eutaw formation, which is believed to be included within the part of the Exogyra ponderosa zone above the Mortoniceras subzone, has yielded the species Salix eutawensis Berry. This species was found by the writer in a cut of the Nashville, Chattanooga \& St. Louis Railway a short distance east of the station at Parsons, Decatur County, Tenn., and was identified by Berry. This form occurs in the extreme basal beds of the Eutaw formation at Broken Arrow Bend on Chattahoochee River and in the Black Creek formation of North Carolina, which indicates that the species ranges from the base of the Eutaw formation well up into the Exogyra ponderosa zone. The presence of the species in the Coffee sand tends to confirm the reference of this division to a position below the Exogyra costata zone; it can not, however, be taken as indicating any particular horizon between the base of the Eutaw formation and the top of the Exogyra ponderasa zone.

Vertebrates.-The following vertebrate species, all sharks, have been collected from beds near the base of the Eutaw formation at Broken Arrow Bend: Corax falcatus Agassiz, Lamna texana Roemer, Otodus appendiculatus Agassiz. As these species are all known to have a wide stratigraphic range they have no value in close correlation.

\section{EXOGYRA PONDEROSA ZONE. ${ }^{2}$}

RANGE OF THE SPECIES.

The species Exogyra ponderosa Roemer makes its first appearance near the base of the Tombigbee sand member of the Eutaw formation and ranges up to about the middle of the Selma chalk and its corresponding nonchalky equivalents. The lower boundary of this zone is shown in Plates IX and $\mathrm{X}$ by the red letter $\mathrm{P}$ and the upper boundary by the red line 2. The restriction of the species in stratigraphic range and its broad geographic distribution within the limits of its

\footnotetext{
1 Berry, E. W., The Upper Cretaceous and Eocene floras of South Carolina and Georgia: Prof. Paper U. S. Geol. Survey No. 84 (in press).
}

2 See pp. $41-50$. 
range render it a characteristic form possessing value in correlation. The appropriateness of the name Exogyra ponderosa to designate the zone in which the species occurs is, therefore, apparent. The species, including its varietal form Exogyra ponderosa var. erraticostata Stephenson, has been found at 69 authentic localities in the belt of outcrop of the zone in the eastern Gulf region. By detailed collecting this number could be multiplied many times.

Within the stratigraphic limits of the zone of Exogyra ponderosa in the eastern Gulf region the following 99 species (questionably 103) are known to orcur:

Fossils from zone of Exogyra ponderosa. ${ }^{\mathfrak{1}}$

Echinodermata:

Cassidulus subquadratus Conrad. a bc. Vermes:

Serpula cretacea (Conrad). $a b c$.

S. sp. (nearly straight tube). $a b c$.

Hamulus onyx Morton. $a b c$.

H. squamosus Gabb. $a b c$.

H. major Gabb. $b c$.

Mollusca:

Nucula percrassa Conrad. $a b c d$.

N. eufalensis Gabb. $a b c$.

N. sp. (cf. undescribed species from Snow Hill, N. C.). bc.

Leda pinnaforma Gabb. $a b c$.

L. longifrons Conrad. $a b c$.

L. protexta Gabb. $a b c$.

Perrisonota protexta Conrad. a bc. Cucullæa carolinensis (Gabb). $b c$.

Trigonoarca maconensis (Conrad). $b c$.

Breviarca umbonata (Conrad). $b c$.

Nemodon brevifrons Conrad. $a b c$.

N. sp. nov. $b c$.

Barbatia lintea Conrad. $b c$

Glycymeris subaustralis (D'Orbigny). $a b c$.

Gervilliopsis ensiformis (Conrad). $a b c$.

Perna sp.nov. (found at Broken Arrow Bend, Ala.-Ga., ete.). $b c d$.

Ostrea plumosa Morton. $a b c$

O. tecticosta Gabb. $a b c$.

O. larva Lamarck. $a b c$.

0 . cretacea Morton. $b c d$.

0 . diluviana Linnæus. $b c$.

O. panda Morton. $a b c$.

O. sp. nov. (large). bc.

O. sp. nov. (first found at House Bluff, Ala.). be d?

O. sp. nov. (also found at Blue Banks Landing, N. C., etc.). $b c$.

o. sp. nov. (very irregular). $a b c$.

o. sp. nov. (from near Hatchechubbee). $b r$.

Gryphæa vesicularis Lamarck. $a b c$.

G. vomer (Morton). $a b c$.

G. aucella Roemer. $b c$.

G. sp. (smooth, convex). $b c$.

Exogyra ponderosa Roemer. $b c$.

E. ponderosa var. erraticostata Stephenson. $b c$.

Trigonia eufalensis Gabb. $a b c$.

T. sp. nov. (also found at Snow Hill, N. C., etc.). $b c$.

Pecten quinquecostatus Sowerby. $a b c$.

P. argillensis Conrad. $a b c$ ?

P. simplicius Conrad. $a b c$.

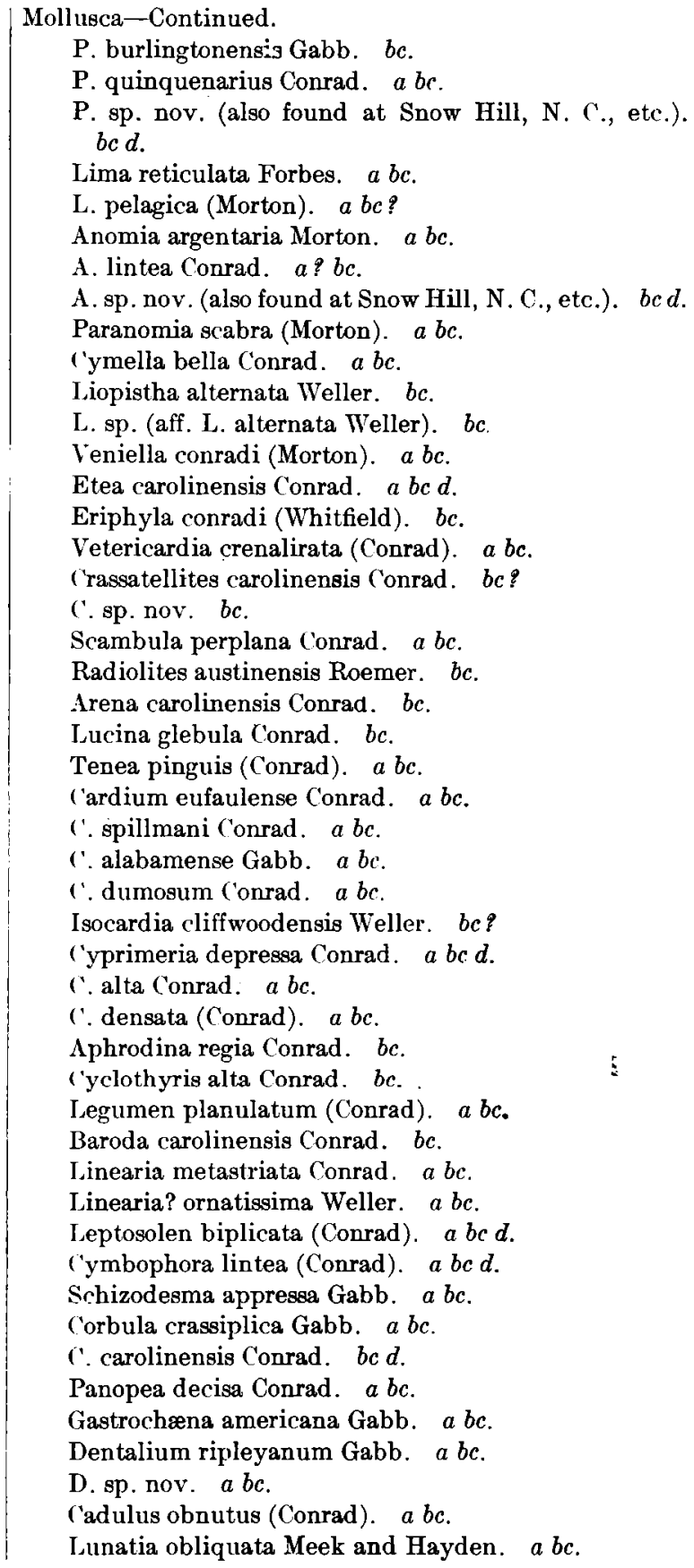

\footnotetext{
1 a, Exogyra costata zone; bc, Exogyra ponderosa zone as a whole, not necessarily both subzones; $d$, basal beds of Eutaw formation.
} 
Mollusca-Continued.

Gyrodes abyssina (Morton). $a b c$.

G. crenata Conrad. $a b c$.

Turritella trilira Conrad. $a b c$.

T. quadrilira Johnson. $b c$.

Nautilus sp. nov. (large). $b c$.

Baculites anceps Lamarck? $b c$.

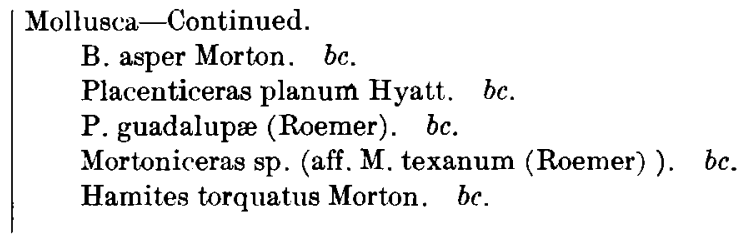

Of the species listed 37 are restricted to the Exogyra ponderosa zone; 10, or questionably 11 , range downward into the basal beds of the Eutaw formation (in the Chattahoochee region only); and 58, or questionably 60, range upward into the overlying Exogyra costata zone. Two, which occur in the zone of Exogyra costata, are questionably present in the Exogyra ponderosa zone.

Of the 37 restricted species 20 occur in the marine invertebrate-bearing beds forming the upper part of the Black Creek formation of the Carolinas, and of these but 1, and that questionably, occurs in the basal beds of the overlying Peedee sand of the same region; in addition 1 Black Creek species is questionably identified from the Exogyra ponderosa zone. Of the 37 species 6 occur ${ }^{1}$ in the Matawan group of New Jersey; and all 6 except the species Liopistha alternata are common to the Black Creek formation of the Carolinas. The genus Mortoniceras, which in the eastern Gulf region occurs only in the Mortoniceras subzone, is present in New Jersey only in the Merchantville clay marl, which forms the basal formation of the Matawan group. None of the 37 species have been reported from the overlying Monmouth group, and but 1, Turritella quadrilira Johnson, from the underlying Magothy formation.

SUBZONES OF THE EXOGYRA PONDEROSA ZONE.

OCCURRENCE OF THE FOSSILS.

The zone of Exogyra ponderosa is divisible paleontologically into two parts-first, the Mortoniceras subzone, which, from Chattahoochee River to Aberdeen, Miss., is regarded as approximately coincident with the Tombigbee sand member of the Eutaw formation, the chief occurrence of the genus Mortoniceras, however, being in the upper 75 to 100 feet of that member; and second, the remainder of the zone, or the part included between the Mortoniceras subzone and the base of the overlying Exogyra costata zone. Localities on Chattahoochee River and in eastern Alabama have yielded the bulk of the species from both of these parts.

The Tombigbee sand, where overlain by the Selma chalk, does not terminate abruptly in its upper part, but passes by gradation through 5 to 10 feet of impure sandy limestone into the overlying chalk rock. The species characteristic of the Mortoniceras subzone are not restricted to the typical Tombigbee sand strata but range upward into these transition beds, for which reason the latter are considered to belong to the Tombigbee sand member rather than to the Selma chalk. In the region between Montgomery, Ala., and the vicinity of Hamburg, in Perry County, Ala., collections have been made at numerous places in fields where the fossils have weathered from these transition beds. For the purpose of this discussion these collections have been considered as coming from the Mortoniceras subzone, although there is admittedly a chance for the intermixture of fossils weathered from slightly higher beds of the Selma chalk. Portions of the matrix, however, adhere to many specimens, thus affording a means of judging of the approximate stratigraphic positions of the beds from which they were weathered. The possible error is in any event too slight to justify discarding the many valuable specimens obtained from this source.

\footnotetext{
1 This statement is made on the assumption that Isocardia cliffwoodensis Weller is correctly identified, and that Lucina glebula Conrad and Lucina cretacea Whitfield are synonymous.
} 
MORTONICERAS SUBZONE.

Seventy-two species, questionably 75 , are known from the Mortoniceras subzone. These are as follows: ${ }^{1}$

Echinodermata :

Cassidulus subquadratus Conrad. $a c$.

Vermes:

Serpula sp. (nearly straight tube). $a c$.

Hamulus onyx Morton. $a b c$.

H. squamosus Gabb. $a b c$.

H. major Gabb. $a b c$.

Mollusca:

Nucula percrassa Conrad. $a b c d$.

N. eufalensis Gabb. a c.

N. sp. (cf. sp. nov. from Snow Hill. X. C.). $b$ c.

Leda longifrons Conrad. $a b c$.

Perrisonota protexta Conrad. a $c$.

Cucullæa carolinensis (Gabb). $b$ c

Breviarca umbonata (Conrad). $c$.

Nemodon sp. nov. $b c$.

Barbatia lintea Conrad. $b c$.

Gervilliopsis ensiformis (Conrad). $a b c$.

Perna sp. nov. (found at Broken Arrow Bend. Ala.-

Ga., etc.). $c d$.

Ostrea plumosa Morton. $a b c$.

O. tecticosta Gabb. $a b c$.

O. cretacea Morton. $c d$.

.o. diluviana Linnæus. $c$.

O. panda Morton. $a b c$.

O. sp. nov. (first found at House Bluff, Ala.). $c d$ ?

O. sp. nov. (also found at Blue Banks Landing, N. C., etc.). $b c$.

O. sp. nov. (from near Hatchechubbee, Ala.). $c$.

Gryphæa aucella Roemer. $b c$.

Exogyra ponderosa Roemer. $b c$

E. ponderosa var. erraticostata Stephenson. $b c$.

Trigonia eufalensis Gabb. a c.

Pecten quinquecostatus Sowerby. $a b c$.

P. argillensis Conrad. $a b ? c$ ?

P. simplicius Conrad. $a b c$.

P. burlingtonensis Gabb. $b c$.

P. sp. nov. ' $c d$.

Lima reticulata Forbes. $a b c$.

L. pelagica (Morton). $a c$ ?

Anomia argentaria Morton. $a b c$.
Fossils from Mortoniceras subzone.

Mollusca-Continued.

Anomia sp. nov. (also found at Snow Hill, N. C.. etc.). $b c d$.

Cymella bella Conrad. $a b c$.

Liopistha alternata Weller. $c$.

L. sp. (aff. L. alternata Weller). c.

Veniella conradi (Morton). $a b c$.

Etea carolinensis Conrad. $a b c d$.

Vetericardia crenalirata (Conrad). $a c$.

Crassatellites carolinensis Conrad. $b ? c$ ?

Radiolites austinensis Roemer. $b c$.

Arena carolinensis Conrad. $c$.

Lucina glebula Conrad. $b ? c$.

Tenea pinguis (Conrad). a c.

Cardium eufaulense Conrad. $a b c$.

C. spillmani Conrad. $a b c$.

Cardium alabamense Gabb. $a c$.

Cyprimeria depressa Conrad. $a b c d$.

Cyclothyris alta Conrad. $b c$.

Legumen planulatum (Conrad). $a b c$.

Linearia metastriata Conrad. $a c$.

Leptosolen biplicata (Conrad). $a b c d$.

Cymbophora lintea (Conrad). $a b c d$.

Schizodesma appressa Gabb. $a b c$.

Corbula crassiplica Gabb. $a b c$.

C. carolinensis Conrad. $b c d$.

Dentalium ripleyanum Gabb. $a b c$.

D. sp. nov. a c.

Cadulus obnutus (Conrad). $a c$.

Lunatia obliquata Meek and Hayden. $a b c$.

Gyrodes abyssina (Morton), a $\boldsymbol{c}$.

G. crenata Conrad. $a b c$.

Turritella trilira Conrad. $a b c$.

T. quadrilira Johnson. $b c$.

Nautilus sp. nov. (large). $c$.

Baculites anceps Lamarck? $c$.

B. asper Morton. $b c$.

Placenticeras planum Hyatt. $c$.

P. guadalupæ (Roemer). c.

Mortoniceras sp. (aff. texanum (Roemer)). c.

Hamites torquatus Morton. c.

Of the species listed 12, questionably 13, are restricted to the Mortoniceras subzone; 10 , questionably 11, range downward into the basal beds of the Eutaw formation; 43, questionably 44, range up into the part of the Exogyra ponderosa zone above the Mortoniceras subzone; 40 of the 72 occur in the Exogyra costata zone. Two known to be present in higher horizons are questionably present in the Mortoniceras subzone. Crassatellites carolinensis Conrad and Corbula carolinensis Conrad, though questionably identified, belong to types not known to range above the zone of Exogyra ponderosa and are here treated as correctly identified.

Of the 13 restricted species 2 occur in the marine invertebrate-bearing beds forming the upper part of the Black Creek formation of the Carolinas, and none are known in the overlying Peedee sand of that region. Of the 13 restricted species, 1, Liopistha alternata Weller, occurs in New Jersey, where it is confined to the Merchantville clay marl which forms the base of the Matawan group. The genus Mortoniceras, which is represented in the eastern Gulf region by

\footnotetext{
I a, Exogyra costata zone; b, Exogyra ponderosa zone above the Mortoniceras subzone; $c$, Mortoniceras subzone; $d$, basal beds of Eutaw formation.
} 
Mortoniceras sp. (aff. M. texanum Roemer), is represented in New Jersey by Mortoniceras delawarense (Morton); the latter is also confined to the Merchantville clay marl.

\section{PART OF EXOGYRA PONDEROSA ZONE BETWEEN THE MORTONICERAS SUBZONE AND THE EXOGYRA} COSTATA ZONE.

From the part of the zone of Exogyra ponderosa included between the top of the Mortoniceras subzone and the base of the Exogyra costata zone 70 species, questionably 74, are known. These are as follows:

Fossils from the part of the Exogyra ponderosa zone betueen the Hortoniceras subzone and the zone of Exogyra costata. ${ }^{1}$

Vermes:

Serpula cretacea (Conrad). $a b$.

Hamulus onyx Morton. $a b c$.

H. squamosus Gabb. $a b c$.

H. major Gabb. $b c$.

Mollusca:

Nucula percrassa Conrad. $a b c d$.

N. sp. (cf. undescribed species from Snow Hill, N. ('.). $b c$.

Leda pinnaforma Gabb. $a b$.

L. longifrons Conrad. $a b c$.

L. protexta Conrad. $a b$.

Cucullæa carolinensis (Gabb). $b c$.

Trigonoarca maconensis (Conrad). $b$.

Nemodon brevifrons Conrad. $a b$.

N. sp. nov. $b c$.

Barbatia lintea Conrad. $b c$.

Glycymeris subaustralis (D'Orbigny). $a b$.

Gervilliopsis ensiformis (Conrad). $a b c$.

Ostrea plumosa Morton. $a b c$.

O. tecticosta Gabb. $a b c$.

O. larva Lamarck. $a b$.

O. panda Morton. $a b c$

O. sp. nov. (large). $b$.

O. sp. nov. (also found at Blue Banks Landing, N. C., etc.). $b c$.

O. sp. nov. (very irregular). $a b$.

Gryphæa vesicularis Lamarck. $a b$.

G. vomer (Morton). $a b$.

G. aucella Roemer. $b c$.

G. sp. (smooth, convex). $\quad b$.

Exogyra ponderosa Roemer. $b$ c.

E. ponderosa var. erraticostata Stephenson. $b c$.

Trigonia sp. nov. (also found at Snow Hill, N. C., etc.). $b$.

Pecten quinquecostatus Sowerby. $a b c$.

P. argillensis Conrad. $a b ? c$ ?

P. simplicius Conrad. $a b c$.

P. burlingtonensis Gabb. $b c$.

P. quinquenarius Conrad. $a b$.

Lima reticulata Forbes. $a b c$.
Mollusca-Continued.

Anomia argentaria Morton. $a b c$.

A. lintea Conrad. $a$ ? $b$.

A. sp. nov. (also found at Snow Hill, N. C., etc.) $b c d$.

Paranomia scabra (Morton). a $b$.

Cymella bella Conrad. $a b c$.

Veniella conradi (Morton). $a b c$.

Etea carolinensis Conrad. $a b c d$.

Eriphyla conradi (Whitfield). $b$.

Crassatellites carolinensis Conrad. $b ? c$ ?

r. sp. nov. $\quad b$

Scambula perplana Conrad. $a b$.

Radiolites austinensis Roemer. $b c$.

Lucina glebula Conrad. $b ? c$.

Cardium eufaulense Conrad. $a b c$.

C. spillmani Conrad. $a b c$.

C. dumosum Conrad. $a b$.

Isocardia cliffwoodensis Weller (?) $b$.

Cyprimeria depressa Conrad. $a b c d$.

C. alta Conrad. $a b$.

C. densata (Conrad). $a b$.

Aphrodina regia Conrad. $b$.

Cyclothyris alta Conrad. $b c$.

Legumen planulatum (Conrad). $a b c$.

Baroda carolinensis Conrad. $b$.

Linearia? ornatissima Weller. $a b$

Leptosolen biplicata (Conrad). $a b c d$.

Cymbophora lintea (Conrad). $a b c d$.

Schizodesma appressa Gabb. $a b c$.

Corbula crassiplica Gabb. $a b c$.

C. carolinensis Conrad. $b c d$.

Panopea decisa Conrad. $a b$.

Gastrochæna americana Gabb. $a b$.

Dentalium ripleyanum Gabb. $a b c$.

Lunatia obliquata Meek and Hayden. $a b c$.

Gyrodes crenata Conrad. $a b c$.

Turritella trilira Conrad. $a b c$.

T. quadrilira Johnson. $b c$.

Baculites asper Morton. $b c$.

Of the species listed 8, questionably 9, are restricted to that part of the zone of Exogyra ponderosa under consideration; 44 range downward into the Mortoniceras subzone; 7 range on downward into the basal beds of the Eutaw formation (Chattahoochee region); and 46, questionably 47, range upward into the zone of Exogyra costata. Crassatellites carolinensis Conrad, though questionably identified, belongs to a flat type of the genus restricted in range below the Exogyra costata zone and is treated as an identified species. Three species are questionably identified from the beds under consideration.

${ }^{1} a$, Exogyra costata zone; $b$, Eıogyra ponderosa zone above Mortoniceras subzone; $c$. Mortoniceras sulyzone; $d$, basal beds of Eutaw formation. 
Of the 9 restricted species 8 (if Isocardia cliffwoodensis Weller is correctly identified) occur in the marine invertebrate-bearing beds forming the upper part of the Black Creek formation of the Carolinas, and 1 of the 8 occurs questionably in the extreme base of the overlying Peedee sand of the same region.

Only 1 of the 9 restricted species, Eriphyla conradi (Whitfield), occurs in the Matawan group of New Jersey, and this one is common to the Merchantville clay marl and the Woodbury clay - the two basal formations of that group. None are known in the overlying Monmouth group of that State.

CORRELATION OF THE EXOGYRA PONDEROSA ZONE. INVERTEBRATES.

The Carolinas. - A study of the invertebrates of the Carolina Cretaceous deposits has shown a restriction in the stratigraphic range of the species Exogyra ponderosa in that region similar to that of the same species in the eastern Gulf region. In the Carolinas the vertical ranges of typical specimens of Exogyra ponderosa and Exogyra costata overlap little if any, the former apparently disappearing at about the horizon where the latter makes its appearance. Exogyra ponderosa occurs in the marine invertebrate-bearing beds forming the upper part of the Black Creek formation. The synchroneity of these beds with at least a part of the Exogyra ponderosa zone of the eastern Gulf region is clearly shown, not only by the presence of this species but by that of numerous other similarly restricted species; for, as shown by the statement of ranges on a preceding page, of 37 species restricted to the zone of Exogyra ponderosa in the eastern Gulf region 20 occur associated with the same species in the Carolinas, and only 1 questionably identified form is known in the overlying Peedee sand in association with Exogyra costata-and that one questionably identified form, Exogyra ponderosa var. erraticostata Stephenson, occurs only in the extreme basal beds of the Peedee sand. The Exogyra ponderosa zone of the eastern Gulf region is therefore with confidence correlated with a part of the Black Creek formation of the Carolinas. However, the apparent absence from the marine invertebrate-bearing beds of the Black Creek formation of those species regarded as characteristic of the Mortoniceras subzone in the eastern Gulf region is taken to indicate that this part of the zone of Exogyra ponderosa is represented in the Carolinas by a part of the Black Creek formation below the invertebratebearing beds of that terrane. The Black Creek fauna is strictly comparable with the fauna from localities on Chattahoochee River between Florence and the lower end of Roods Bend, Stewart County, Ga., an air-line distance of 5 to 6 miles, and from localities in the vicinity of Union Springs, Bullock County, Ala. These beds represent a part of the zone of Exogyra ponderosa above the Mortoniceras subzone.

New Jersey.-In the New Jersey Cretaceous the species Exogyra ponaerosa and Exogyra costata do not overlap in their ranges, the former being known only from the Marshalltown formation of the Matawan group, and the latter being restricted to the Monmouth group. Of the 37 species which in the eastern Gulf region are restricted to the zone of Exogyra ponderosa, 6 are common to the Matawan, and none of the 37 are known in the Monmouth (Exogyra costata zone of New Jersey). All of the 6 except the species Liopistha alternata Weller, occur in the marine invertebrate-bearing beds of the Black Creek formation of the Carolinas.

It is believed, therefore, that the Matawan represents approximately the Exogyra ponderosa zone of the eastern Gulf region. The occurrence of the genus Mortoniceras and the species Liopistha alternata Weller in the Merchantville clay marl, which forms the basal formation of the Matawan group, is taken to indicate that the Merchantville is synchronous with the Mortoniceras subzone (lower part of zone of Exogyra ponderosa) of the eastern Gulf region, these two forms being considered characteristic of that horizon. However, specimens of Mortoniceras which have been referred to Mortoniceras delawarense (Morton) have been obtained from the Campanien (upper Senonian) of France, ${ }^{1}$ and specimens referred to Mortoniceras texanum (Roemer) have come from the lower part of the Santonien (lower Senonian) of the same country. ${ }^{2}$

\footnotetext{
1 Pervinquière, L., Céphalopodes des terrains secondaires: Carte géologique de la Tunisie, Études de la paléontologie tunisienne, I, 1907, pp. 243-245, Pl. XI, figs. $21 \mathrm{a}-\mathrm{b}, 22$.

2 De Grossouvre, $A$., Les ammonites de la craje supéricure: Mém. expl. Carte géol. de la France-Recherches sur la craie supérieure, paléontologie, pt. 2, 1896, pp. 80-83, Pl. XVI, figs. 2, 3a, 3b, 4a, 4b, Pl. XVII, figs. 1a, $1 \mathrm{~b}$.
} 
It is not certain that these forms have been correctly identified with the American species, but in view of the higher range of the genus in the European Cretaceous than in the supposed corresponding deposits in America it is best not to rely too strongly on this evidence in attempting to correlate exactly the eastern Gulf and New Jersey Cretaceous deposits. The remainder of the Matawan group, including in ascending order the Woodbury clay, the Englishtown sand, the Marshalltown formation, and the Wenonah sand, is believed to correspond to the part of the zone of Exogyra ponderosa between the Mortoniceras subzone and the base of the zone of Exogyra costata of the eastern Gulf region.

Texas.-The Mortoniceras subzone contains a number of mollusca known to be common to the Austin chalk of Texas and particularly to the upper part of that formation. These are as follows:

$$
\text { Fossils common to Mortoniceras subzone and Austin chalk. }
$$

Ostrea diluviana Linnæus.

Gryphæa aucella Roemer.

Baculites anceps Lamarck?

Exogyra ponderosa Roemer.

Radiolites austinensis Roemer.

$$
\begin{aligned}
& \text { B. asper Morton. } \\
& \text { Placenticeras planum Hyatt. } \\
& \text { P. guadalupæ (Roemer). }
\end{aligned}
$$

In the eastern Gulf region 4 of the species named in the list-Gryphæa aucella Roemer, Exogyra ponderosa Roemer, Radiolites austinensis Roemer, and Baculites asper Morton-are known to range above the Mortoniceras subzone into the basal beds of the overlying Selma chalk. The remainder appear to be restricted to the Mortoniceras subzone. In Texas 1 of the listed species, Exogyra ponderosa Roemer, is known to range above the Austin chalk into the Taylor marl, and it is probable that future studies will reveal a higher range for some of the other species. Mortoniceras sp. (aff. M. texanum Roemer) of the eastern Gulf region is probably represented in the Austin chalk, but this has not been certainly verified. It seems probable that the Mortoniceras subzone of the eastern Gulf region will be found to be synchronous with a part of the Austin chalk.

This correlation has auready been suggested by Stanton. ${ }^{1}$ Referring to the occurrence of Placenticeras syrtale var. halei Hyatt in Greene County, Ala., he says in a footnote quotation by Hyatt: "Age: This specimen is probably from the Eutaw beds, which are probably very near the horizon of Placenticeras guadalupæ [Austin chalk] in Texas." Stanton, ${ }^{2}$ in discussing the distribution of faunas of Colorado age, with which the Austin chalk is correlated, also states:

No marine faunas of Colorado age are known in the Atlantic and Gulf borders east of western Arkansas, unless possibly the imperfectly known fauna of the Eutaw or "Tombigbee" sand of Mississippi belongs to its latest phase.

However, so little is known of the fauna of the overlying Taylor marl that an attempt at exact correlation would be premature, especially as investigations are now being conducted in that region.

VERTEBRATES.

Teeth and fragmental bones of vertebrates occur in places in the Exogyra ponderosa zone in the eastern Gulf region. The following species of fish have been identified:

Fish remains from Exogyra ponderosa zone.

Corax falcatus Agassiz (shark).

Lamna texana Roemer (shark).

Otodus appendiculatus Agassiz (shark).

Ischyrhiza mira Leidy (identified by J. W. Gidley).
Enchodus? petrosus Cope (identified by J. W. Gidley). Ptychodus martini Williston? Hemiptychodus mortoni Mantell.

The 5 first-named forms have a wide vertical range and are of no value in close correlation. The species Ptychodus martini Williston? and Hemiptychodus mortoni Mantell are limited in range in the eastern Gulf region to the Mortoniceras subzone; in the western interior region these species occur in the Niobrara formation, but are not known above that formation. These forms may prove of value in correlating the eastern Gulf Cretaceous with that of the western interior,

1 Hyatt, Alpheus, Pseudoceratites of the Cretaceous: Mon. U. S. Geol. Survey, vol. 44, 1903, p. 206.

Stanton, T. W., Succession and distribution of later Mesozoic invertebrate faunas in North America: Jour. Geology, vol. 17, No. 5, 1909 , p. 419. 
although at present their ranges can scarcely be said to be known with sufficient definiteness to permit confident correlation.

Teeth and fragmental bones of reptiles, including dinosaurs, mosasaurs, crocodiles, and turtles, have been found at numerous localities in the zone, but are for the most part too fragmentary to permit specific determination. Two species of crocodiles, Thecachampsa rugosa Emmons, and Polydectes biturgidus Cope, from Roods Bend, Chattahoochee River, identified by C. W. Gilmore, are said by Mr. Gilmore to be identical with species obtained from Phoebus Landing, Cape Fear River, N. C., an upper Black Creek horizon. The evidence furnished by these forms tends, therefore, to corroborate the evidence afforded by the fossil invertebrates.

\section{PIANTs.}

Fossil plants have been found at two localities in the Cusseta sand member of the Ripley formation in Georgia. Stratigraphically, this member falls within that part of the zone of Exogyra ponderosa included between the Mortoniceras subzone and the base of the zone of Exogyra costata. One of these localities is in Marion County, 6 miles northeast of Buena Vista. E. W. Berry, to whom the plants were submitted, recognized six species from this locality, as follows:

Andromeda novæcæsareæ Hollick.

Araucaria bladenensis Berry.

Eucalyptus angusta Velenovsky.

Doryanthites cretaceum Berry.
Ficus georgiana Berry

Manihotites georgiana Berry (same as at McBride Ford).

Monocotyledon, gen. et sp. nov. (common to the Black Creek and Tuscaloosa formations).

Concerning these he says: ${ }^{1}$

Three of the foregoing species occur in the underlying Eutaw formation, and all but the Ficus, which is new, are found in the Black Creek formation of North and South Carolina. The Andromeda is a characteristic species of the Black Creek formation and one of the type fossils of the Magothy formation of the northern Coastal Plain, although it makes its earliest appearance in the Raritan formation, as does also the Eucalyptus. None of the six genera except Ficus are represented in the flora of the Montana group, and the latter is represented by very different species. It seems clear, then, that the Cusseta sand is pre-Montana in age and that it falls within the same general paleobotanic limits that include the Magothy-Matawan, typical Black Creek, Middendorf, and upper Tuscaloosa floras of the East and the flora of a part of the Dakota eandstone of the West.

The other locality is in Houston County, $1 \frac{1}{2}$ miles northeast of Byron. Concerning these Berry says:

These plants number but three species-Dryopterites stephensoni Berry, Cunninghamites elegans (Corda) Endlicher, and Araucaria jeffreyi Berry, the first-named form being new to science.

As Dryopterites occurs in the Lower Cretaceous, Dryopteris-like forms are found in post-Cretaceous floras down to the present time, and Dryopteris (Aspidium) is to-day a widespread and dominant genus of ferns, the Georgia species, which is unlike any of the described forms, is of no value in correlation. Of the other two forms, Cunninghamites elegans has a rather wide geographic range, occurring both in this country and abroad, and a considerable geologic range. In Europe it ranges from the Cenomanian to the Senonian, inclusive, and in this country it has a parallel range, from the Magothy flora of the East to the Montana flora of the West. It has been recorded from Lower Cretaceous horizons in Europe, but these determinations are believed to be erroneous. The nearest geographic occurrence to that in Georgia is that of the upper part of the Black Creek formation of North Carolina; hence the conclusion that the exposures near Byron are not older than those of the Black Creek and not younger than those of the Montana group appears to be firmly established.

The remaining species, Araucaria jeffreyi, is not a widespread form, and its intimate association with Araucaria bladenensis in the Eutaw formation at Chimney Bluff, Ga., and in the Black Creek formation of North Carolina indicates that it may represent cone scales of the latter species. Taken alone, Araucaria jeffreyi points to the same conclusion regarding the age of the deposits near Byron as does the distribution of Araucaria bladenensis, but the latter furnishes more definite data.

Araucaria bladenensis is one of the most abundant and typical forms of the Black Creek formation in North and South Carolina, ranging from its base to its summit. It has also been found in the Cusseta sand member of the Ripley formation near Buena Vista, in the Eutaw formation just below the Tombigbee and member at Chimney Bluff, and in the base of the Eutaw formation in western Alabama. A closely allied or identical form occurs in the Magothy of Maryland and New Jersey, and a similarly allied form has been described from the Turonian of Bohemia.

1 Berry, E. W., The Upper Cretaceous and Eocene floras of South Carolina and Georgia: Prof. Paper U. S. Geol. Survey No. 84 (in press). $105^{\circ}-$ No. $81-14-3$ 
The evidence afforded by the fossil plants is in harmony, therefore, with that afforded by the fossil invertebrates so far as the correlation of the formation with the Black Creek formation of the Carolinas is concerned. As regards the New Jersey Cretaceous, however, Berry apparently regards the beds as corresponding to a somewhat earlier horizon than that indicated by the invertebrates-namely, to the Magothy formation. However, he admits elsewhere ${ }^{1}$ that the Magothy flora possibly persisted to a later time in the Carolinas and Georgia than in New Jersey.

\section{EXOGYRA COSTATA ZONE. ${ }^{2}$}

RANGE OF THE SPECIES.

Typical specimens of Exogyra costata Say make their first appearance just above the zone of Exogyra ponderosa and range upward to the top of the Cretaceous. The lower limit of this range is indicated on Plates IX and X by red line 2, and the upper limit is coincident with the upper surface of the typical marine Cretaceous beds of the region. Between these two limits the species has a general geographic distribution throughout the typical marine beds.

The name Exogyra costata is therefore obviously appropriate as a zonal designation. The species, including its varietal form Exogyra costata var. cancellata Stephenson, has been collected from 90 authentic localities within the geographic limits of the zone in the eastern Gulf region. This number could be multiplied many times by detailed collecting.

Young individuals of the genus with well-developed, fairly typical costæ, some approaching the average size of the adult Exogyra costata, have been found at rare intervals below the lower limit of the zone of Exogyra costata as indicated-that is, have been found in the zone of Exogyra ponderosa. Such specimens may perhaps be regarded as the ancestors of the well-developed costate forms of higher horizons.

In the eastern Gulf region 185 species, questionably 187, are known in the zone of Exogyra costata. These are as follows: ${ }^{3}$

Fossils from Exogyra costata zone.

Echinodermata:

Cassidulus porrectus Clark. a.

C. subconicus Clark. $a$.

C. micrococcus Gabb. a.

C. subquadratus Conrad. ac.

C. intermedius Slocum. $a$.

Hemiaster ungula (Morton). a.

H. parastatus (Morton). a.

$\mathrm{H}$. lacunosus Slocum. $a$.

?Coptosoma mortoni (De Loriol). a.

Rhizocrinus alabamensis De Loriol. $a$.

?Linthia variabilis Slocum. $a$.

Vermes:

Serpula cretacea (Conrad). $a b$.

S. barbata Morton. a.

S. sp. (nearly straight tube). a c.

Hamulus onyx Morton. $a b c$.

$H$. squamosus Gabb. $a b c$.

Molluscoidea:

Terebratulina floridana (Morton). a.

T. flosa Conrad. a.

Mollusca:

Nucula percrassa Conrad. $a b c d$.

N. cuneifrons Conrad. a.

N. eufalensis Gabb. a. $c$.

Leda pinnaforma Gabb. $a b$. c. conoideus Clark. $a$.

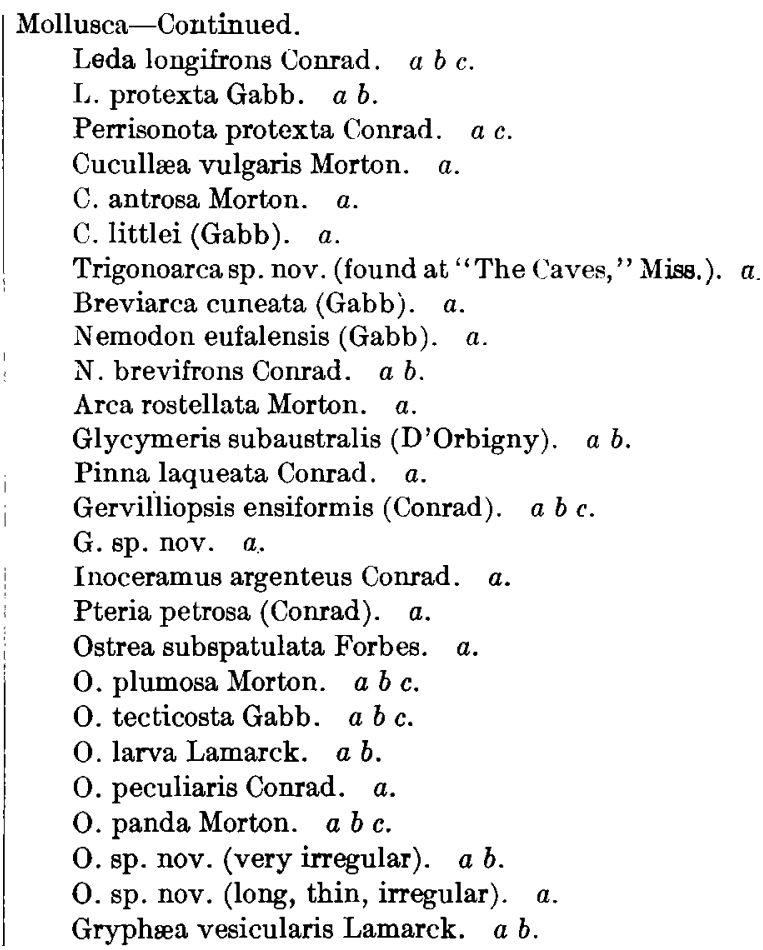

I Berry, E. W., The Upper Cretaceous and Eocene floras of South Carolina and Georgia: Prof. Paper U. S. Geol. Survey No. 84 (in press). 2 See pp. 41-55.

a, Exogyra costata zone; b, Exogyra ponderosa zone above Mortoniceras subzone; c, Mortoniceras subzone; d, basal beds of Eutaw formation. 
Mollusca-Continued.

Gryphæa vomer (Morton). $a b$.

Exogyra costata Say. a.

E. costata var. cancellata Stephenson. $a$.

Trigonia eufalensis Gabb. $a c$.

T. thoracica Morton. a.

T. angulicostata Gabb. a.

Pecten quinquecostatus Sowerby. $a b c$.

P. argillensis Conrad $a b ? c$ ?

P. simplicius Conrad. $a b c$.

P. quinquenarius Conrad. $a b$.

P. tenuitestus Gabb. a.

P. parvus (Whitfield). $a$.

$P$. venustus Morton. $a$.

P. conradi (Whitfield). a.

Dianchora echinata Morton. a.

Plicatula urticosa (Morton). a.

P. sp. nov. (found at Livingston, Ala., etc.). $a$.

P. sp. nov. (first found at Demopolis, Ala.). a.

Lima reticulata Forbes. $a b c$.

I. acutilineata (Conrad). $a$.

L. pelagica (Morton). $a c$ ?

L. sp. nov. $a$.

Anomia argentaria Morton. $a b c$.

A. linifera Conrad. $a$.

A. lintea Conrad. a? $b$.

A. ornata Gabb. $a$.

A. sp. nov. (found at Bartons Bluff, Ala., etc.). $a$.

Paranomia scabra (Morton). $a b$

Pulvinites argentea Conrad. $a$.

Crenella serica Conrad. a.

C. elegantula Meek and Hayden (?). a.

Dreissensia tippana Conrad. $a$.

Pholadomya occidentalis Morton. a.

P. littlei Gabb. $a$.

Lithophaga ripleyana Gabb. a.

Periplomya applicata Conrad. $a$.

Anatimya anteradiata Conrad. $a$.

A. postsulcata (Conrad). a.

Cymella bella Conrad. $a b c$.

Liopistha protexta Conrad. $a$.

Cuspidaria ventricosa Meek and Hayden. $a$.

C. jerseyensis Weller. a.

Veniella conradi (Morton). $a b c$.

Etea carolinensis Conrad. $a b c d$.

Vetericardia crenalirata (Conrad). a c.

Crassatellites vadosa Morton. a.

C. eufalensis Gabb. a.

C. ripleyana Conrad. a.

C. pteropsis Conrad. a.

C. sp. nov. $a$.

Scambula perplana Conrad. $a b$.

Tenea pinguis (Conrad). a $c$.

Sphærella concentrica Conrad. a.

Cardium eufaulense Conrad. $a b c$.

C. spillmani Conrad. $a b c$.

C. kümmeli Weller. $a$.

C. tippanum Conrad. a

C. alabamense Gabb. a c.

C. dumosum Conrad. $a b$.

Protocardium sp. nov. $a$.
Mollusca-Continued.

Cyprimeria depressa Conrad. $a b c d$.

C. alta Conrad. $a b$.

C. densata (Conrad). $a b$.

Aphrodina tippana (Conrad). a.

Legumen planulatum (Conrad). $a b c$.

Enona eufalensis Conrad. $a$.

Linearia metastriata Conrad. a c.

L.? ornatissima Weller. $a b$.

L. sp. nov. (from Pataula Creek, Ga.). a.

L. sp. nov. (from near Wenasoga, Miss.). a.

Gari elliptica Gabb. a.

Leptosolen biplicata (Conrad). $a b c d$.

Cymbophora lintea (Conrad). $a b c d$.

Schizodesma appressa Gabb. $a b c$.

Corbula crassiplica Gabb. $a b c$.

Panopea decisa Conrad. $a b$.

Gastrochæna americana Gabb. $a b$.

Pholas cithara Morton. a.

Dentalium ripleyanum Gabb. $a b c$.

D. sp. nov. $a c$.

(adulus obnutus (Conrad), a $c$.

Delphinula lapidosa Morton. $a$.

Perissolax octolirata (Conrad). $a$.

Trichoptropis? cancellaria Conrad. a.

Scala sillimani (Morton). a.

Lunatia obliquata Meek and Hayden $a b c$.

Gyrodes petrosa (Morton). $a$.

G. abyssina (Morton). $a \dot{c}$.

G. crenata Conrad, $a b c$.

Xenophora leprosa (Morton). a.

Turritella vertebroides Morton. a.

T. tippana Conrad. $a$.

T. trilira Conrad. $a b c$.

T. sp. nov. (two spiral ridges). $a$.

T. sp. nov. (very large). a.

Laxispira lumbricalis Gabb. $a$.

Pterocerella tippana (Conrad). $a$.

Anchura abrupta Conrad. a.

A. decemlirata Conrad. a.

A. rostrata (Gabb). a.

Pugnellus densatus Conrad. a.

Pyropsis perlata Conrad. a.

Strepsidura interrupta Conrad. $a$.

Rapana stantoni Weller. $a$.

Fusus holmesianus Gabb. a.

F. tippanus Conrad. a.

F.? novemliratus Conrad. a.

Pyrifusus bellaliratus Conrad. $a$.

P. subdensatus Conrad. $a$.

Liopeplum cretacea (Conrad), $a$

L. canalis (Conrad). $a$.

L. liodermum (Conrad), a.

L. subjugosum (Gabb). a.

Volutomorpha dumasensis Dall. $a$.

V. eufalensis (Conrad). a.

Morea cancellaria Conrad. a.

Pleurotoma? melanopsis (Conrad). a.

P.? laqueata (Conrad). a.

Drillia? novemlirata Conrad. $a$.

Daphnella? lintea Conrad. a. 
Mollusca-Continued.

D.? subfilosa Conrad. a.

Acteon linteus Conrad. a.

Ringicula pulchella Shumard. $a$.

Bullopsis cretacea Conrad. a.

Bulla macrostoma Gabb. a.

B. mortoni Forbes. a.

Cylichna recta Gabb. $a$.

Nautilus dekayi Morton. a.

Baculites columna Morton. $a$.

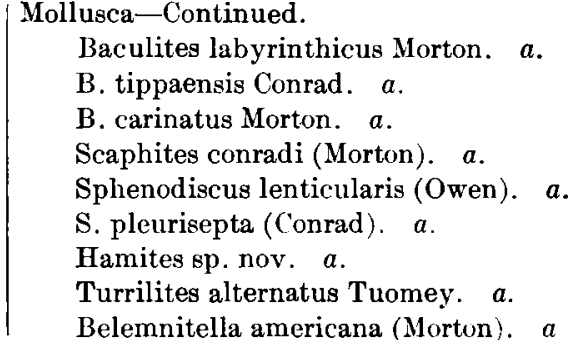

Of the 187 species listed above, 127 are restricted to the Exogyra costata zone; 57, questionably 59, range below it. One species which occurs at a lower horizon is questionably present in this zone.

SUBZONES.

OCCORRENCE OF THE FOSSILS.

In the eastern Gulf region the zone of Exogyra costata is relatively prolific in species as compared with the zone of Exogyra ponderosa, the former containing about 85 per cent more than the latter. Although no exact figures have been prepared, much the greater number of species have come from the upper half of the zone. The most prolific fossil localities are found in the Ripley formation in Tippah and Union counties, Miss., and in the bluffs of Chattahoochee River from Eufaula, Ala., downstream to the mouth of Pataula Creek, Ga. That part of the zone represented by the Selma chalk (see Pls. IX in pocket and X, p. 20) in Alabama and Mississippi contains fewer species than the part represented by the Ripley type of materials. With the exception of a horizon near the top of the chalk formation, to be described below, the Selma chalk fossils (not including the Foraminifera) belong chiefly to the Ostreidæ and Anomiidæ families. This relative paucity of species in the chalk formation may be due in part to unfavorable life conditions in the area where chalk was being deposited, or to unfavorable conditions of preservation, or to both.

IIOPISTHA PROTEXTA SUBZONE.

Toward the close of the deposition of the chalk formation the conditions for the existenco of life and for the preservation of life remains were favorable, as is shown by the presence of a considerable fauna in the upper 40 or 50 feet of the terrane, here designated the Liopistha protexta subzone. This subzone is traceable along the top of the Selma chalk in western Alabama and east-central Mississippi, being coincident in the former State with the thin tongue of chalk rocks which runs eastward above the sands of the Ripley formation in Marengo and Wilcox counties, and in the latter State with the similar tongue of chalk running north through Oktibbeha, Clay, and Chickasaw counties. (See red line 3, Pls. IX and X.) Excepting the Ostreidæ, Pectinidæ, Spondylidæ, Limidæ, and Anomiidæ, the shells of which are usually preserved, the fossils present in the Liopistha protexta subzone in the Selma chalk are preserved chiefly in the form of casts, the materials of which are, as a rule, more or less phosphatic. Of the 40 or 50 species obtained the forms listed below appear to be restricted, within the area of the Selma chalk, to the Liopistha protexta subzone; some of them, how əver, as explained below, are known to have a somewhat greater stratigraphic range in the nonchalky equivalents of the chalk elsewhere in the eastern Gulf region and northward in the Atlantic coast region. Because of its wide geographic distribution in the uppermost beds of the Selma chalk the species Liopistha protexta Conrad has, for convenience, been chosen to designate the subzone. 
Species characteristic of Liopistha protexta subzone.

Echinodermata:

Hemiaster lacunosus Slocum.

Molluscoidea:

Terebratulina floridana (Morton).

Mollusca:

Cucullæa vulgaris Morton.

Exogyra costata Say (variation with narrow, strong costæ).

Trigonia thoracica Morton.

Pecten venustus Morton.

Plicatula urticosa (Morton).

P. sp. nov.

Liopistha protexta Conrad.

Crassatellites vadosa Morton.

Delphinula lapidosa Morton.

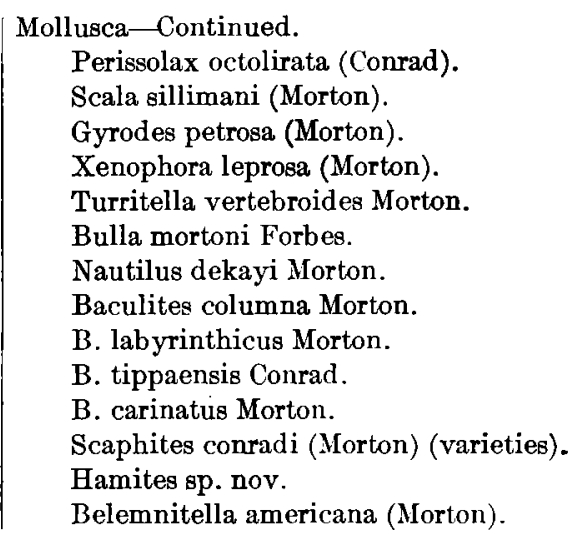

The Liopistha protexta subzone is traceable from the Selma chalk into the Ripley formation, both northward in Mississippi and eastward in Alabama. In each direction there seems to be some expansion in the vertical ranges of most of the characteristic species, rendering the limits of the subzone less definite in the Ripley type of materials than in the Selma chalk.

EXTREME UPPER CRETACEOUS BEDS.

In places in the eastern Gulf region certain faunal elements, which seem to indicate a slightly higher stratigraphic position and a slightly younger age for the beds containing them than that of the Liopistha protexta subzone, appear in the extreme uppermost beds of the Cretaceous in association with large numbers of other species common to the underlying beds. This horizon, however, is within the zone of Exogyra costata. The exposures on Chattahoochee River from Alexanders Bluff, 8 miles below Eufaula, to the mouth of Pataula Creek, and the exposures at the "Narrows" of Pataula Creek, 2 miles above its mouth, fall within this class. These newly introduced elements are represented by the following forms:

Nexly introduced species in extreme uppermost beds of the Cretaceous.

Echinodermata:

Cassidulus porrectus Clark.

C. subconicus Clark.

C. conoideus Clark.

Mollusca:

Cucullæa littlei (Gabb).

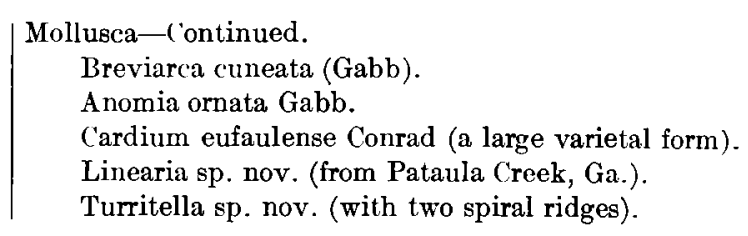

Indications of this higher horizon have also been noted in cuts north of Fort Deposit in Lowndes County, Ala., in an exposure a mile south of Houston, in Chickasaw County, Miss., and in an exposure 3 miles south of New Albany in Union County, Miss.

\section{CORRELATION OF THE ZONE.}

INVERTEBRATES.

The Carolinas.- The zone of Exogyra costata of the eastern Gulf region finds its counterpart in the Peedee sand of the Carolinas. Typical specimens of Exogyra costata make their first appearance in the basal beds of the Peedee sand and range to its summit. The fauna of the Peedee is small as compared with that of the corresponding deposits in the eastern Gulf region, the number of species known from the terrane being but 35 . Of the 127 species restricted to the zone of Exogyra costata in the eastern Gulf region, 11 occur in the Peedee sand, and 4, questionably 5, in the underlying Black Creek formation. Of the 11 species only 1 ranges down into the Black Creek formation and this one is known only in the extreme uppermost beds of that formation. In contrast, the Black Creek fauna is large, including 92 known species. With so large a Black Creek fauna it is significant that of the 127 species restricted 
to the zone of Exogyra costata in the eastern Gulf region only 5 are known below that zone in the Carolinas.

Of the 11 Peedee species common to the Exogyra costata zone of the eastern Gulf region the following 10 are regarded as peculiarly characteristic of that zone:

$$
\text { Species especially characteristic of Exogyra costata zone in the Carolinas. }
$$

Mollusca:

Ostrea subspatulata Forbes.

Exogyra costata Say (typical specimens).

E. costata var. cancellata Stephenson.

Lima acutilineata (Conrad).

Pholadomya littlei Gabb.

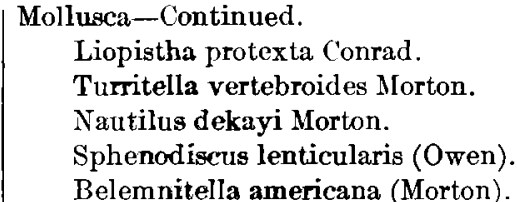

It is on the evidence of the species just enumerated that the Peedee sand is correlated with the zone of Exogyra costata of the eastern Gulf region.

New Jersey.-In New Jersey the species Exogyra costata is limited in range to the Monmouth group, which includes the Mount Laurel sand, the Navesink marl, and the Redbank \$and. Of the 127 species restricted to the zone of Exogyra costata in the eastern Gulf region, 3 speeies are known in the Rancocas formation, which overlies the Monmouth group; 29 species, questionably 32 , in the Monmouth; 19 species, questionably 24, in the Matawan group above the Merchantville clay marl, its basal formation; 10 species, questionably 11, in the Merchantville clay marl; and 2 species, questionably 3 , in the Magothy formation. Of the 32 species common to the Monmouth group, 16, questionably 18, are restricted to that group, and 4, questionably 5 , range down only into the Wenonah sand, which forms the uppermost formation of the Matawan group. Of the 18 restricted species in New Jersey the following are regarded as especially sharacteristic of the Exogyra costata zone:

Species especially characteristic of the Exogyra costata zone in New Jersey.

Mollusca:

Cucullæa littlei (Gabb).

Exogyra costata Say.

Pecten venustus Morton.

Dianchora echinata Morton.

Plicatula urticosa (Morton).

Cuspidaria jerseyensis Weller.

Cardium kümmeli Weller.

Xenophora leprosa (Morton).
Mollusca--Continued.

Turritella vertebroides Morton.

Anchura abrupta Conrad.

Bulla macrostoma Gabb.

B. mortoni Forbes.

Nautilus dekayi Morton.

Sphenodiscus lenticularis (Owen).

Belemnitella americana (Morton).

The species enumerated are taken to indicate the synchroneity of the Monmouth group with the Exogyra costata zone of the eastern Gulf region.

Texas.- The fauna of the Navarro formation of Texas has long been correlated with the fauna of the Ripley formation of Tippah County, northern Mississippi. Although a eritical comparison of the two faunas has not been made it is known that many species regarded as characteristic of the Ripley beds of Tippah County, and in general of the Exogyra costata zone of the eastern Gulf region, are common to the Navarro formation. There is abundant reason, therefore, for regarding the correlation as correct. Little is known of the fauna of the Taylor marl, which in Texas intervenes between the Austin chalk and the Navarro formation. The exact correlation of the Taylor marl is therefore one of the problems awaiting solution.

VERTEBRATES.

A few vertebrate remains represented by teeth and fragmentary bones have been found in this zone. Teeth of the following fishes have been identified:

Fish remains from zone of Exogyra costata.

Enchodus ferox Leidy (identified by. J. W. Gidley). Enchodus? petrosus Cope (identified by J. W. Gidiey). Ischyrhiza mira Leidy (identified by J. W. Gidley).
Galeocerdo sp. (shark) (identified by J. W. Gidley).

Corax falcatus Agassiz (shark).

Lamna texana Roemer (shark). 
A few fragmental remains of mosasaurs, crocodiles, and turtles have been found in the zone, but all are too imperfect for specific determination.

Too little is known concerning the vertical ranges of the vertebrate animals to render them of value in exact correlation.

PLANTS.

With the exception of a few pieces of lignite or comminuted plant fragments, fossil plants have been found at but one locality in the zone of Exogyra costata. A few imperfect leaf remains were collected near the base of the zone on Cowikee Creek, a few hundred yards aboveits junction with Chattahoochee River, in Barbour County, Ala.

E. W. Berry, who collected and studied these specimens, in a letter to the writer says:

The fossil plants from Cowikee Creek are few in number and poorly preserved. The following forms are represented:

Bauhinia sp. nov.

Platanus sp. nov.

Laurus sp.

Salix sp.

Sapindus sp.

Fern, not determinable.

The remains of the Bauhinia and Platanus are complete enough to demonstrate that they are new. The balance are too poor for accurate determination, although they all appear to be distinct from any forms of the earlier eastern Cretaceous floras.

The slight evidence afforded by these plant remains seems to indicate that a change took place in the Cretaceous flora of the region almost coincidently with the appearance of the fauna characterizing the zone of Exogyra costata.

\section{SUMMARY.}

In eastern Alabama and in Georgia a terrane, previously regarded as forming the eastward continuation of the Tuscaloosa formation of western Alabama, has been shown by its fossil plant remains, on the authority of E. W. Berry, to be of Lower Cretaceous age and hence older than the Tuscaloosa formation. The fossil plants furnishing the evidence for this determination of age are too poor to permit exact correlation with better known floras elsewhere; but the presence of large numbers of leaves, apparently dicotyledons, most of which are too poorly preserved to permit accurate determination, seems to indicate that they are younger than the Patuxent formation of the Potomac group (Virginia and Maryland) in which similar questionably identified dicotyledons are but sparingly represented.

The Tuscaloosa formation, the oldest of the Upper Cretaceous formations of the region, has yielded no invertebrate fossil remains, but a large number of plant species have been obtained from it. E. W. Berry, who is engaged in a study of the flora, correlates the basal portion of the formation with the Raritan formation of New Jersey and the remainder of the formation with the lower part of the Black Creek formation of the Carolinas (including the Middendorf arkose member) and with the whole or at least a part of the Magothy formation of New Jersey.

The Upper Cretaceous deposits above the Tuscaloosa formation are divisible on the basis of their lithologic differences into formations and members. The physical relations of these units to each other are such that it is not possible clearly to represent their age relationships by the usual methods of mapping, for in many places the boundaries of lithologic units run obliquely to the general strike of the beds and do not coincide with the boundaries of paleontologic zones and subzones, and in several places important tongues of one unit project into the body of another unit. On the basis of the distribution of the contained invertebrate fossils these deposits have been divided into faunal zones and subzones whose positions are maintained along the direction of the strike of the typical marine beds irrespective of lithologic variations. These paleontologic parts furnish the means of correlating the deposits of the eastern Gulf region with corresponding deposits in the Atlantic coast region. The relations of the paleontologic zones and subzones to the lithologic units are graphically represented in Plates IX and X.

The paleontologic parts recognized and their correlations are briefly summarized as follows:

1. The basal beds of the Eutaw formation in the Chattahoochee region. These beds are believed to be represented in the Carolinas by noninvertebrate-bearing beds making up the 
middle or lower portion of the Black Creek formation; they have been recognized paleontologically in a well boring at Charleston, S. C., at depths of 1,974 to 2,007 feet. In New Jersey they are represented by an undetermined upper portion of the Magothy formation.

2. The Exogyra ponderosa zone, divisible into the Mortoniceras subzone and the remainder of the zone (included between the Mortoniceras subzone and the base of the Exogyra costata zone).

The Mortoniceras subzone is represented in the Carolinas by a part of the Black Creek formation immediately beneath the invertebrate-bearing beds forming the upper part of the formation, and in New Jersey probably by the Merchantville clay marl, the lowest formation of the Matawan group. The remainder of the zone is represented in the Carolinas by the marine invertebrate-bearing beds forming the upper part of the Black Creek formation, and in New Jersey by the Matawan group exclusive of the basal formation or Merchantville clay marl.

3. The Exogyra costata zone, represented in the Carolinas by the Peedee sand and in New Jersey by the Monmouth group.

Through a part of the eastern Gulf region the Liopistha protexta subzone is traceable near the top of the Exogyra costata zone, and, locally in the region, in beds believed to be slightly higher than those carrying the Liopistha protexta fauna, new faunal elements are introduced in association with species common to the Exogyra costata zone. The former has not been differentiated in either the Carolinas or New Jersey Cretaceous; the latter is probably represented in the Cretaceous beds exposed at and near Wilmington, N. C. 


\title{
SPECIES OF EXOGYRA FROM THE EASTERN GULF REGION AND THE CAROLINAS.
}

\author{
By Lloyd William Stephenson.
}

INTRODUCTION.

In the preceding paper on "The Cretaceous deposits of the eastern Gulf region," the two principal representatives of the genus Exogyra, namely, Exogyra ponderosa Roemer and Exogyra costata Say, have been used to designate the two principal faunal zones recognizable in the marine Upper Cretaceous deposits of the eastern Gulf region. On account of the prominence thus given to the genus and the inadequacy of the information previously published concerning its representatives in the region, the inclusion of the present paper in this report is deemed appropriate.

The United States National Museum contains a large collection of Upper Cretaceous invertebrate fossils obtained during the past 25 or 30 years from localities in the eastern Gulf region and in the Carolinas. These have been collected chiefly by L. C. Johnson, T. W. Stanton, and the writer. A number of other persons have made small contributions.

Among these collections are many specimens of Exogyra from horizons between the base and the top of the marine Cretaceous deposits. Indeed, here, as also throughout nearly the whole of the marine Upper Cretaceous deposits of the Atlantic and Gulf Coastal Plain, representatives of the genus are among the most abundant and generally distributed fossils.

All the species and varieties of the genus now recognized in the eastern Gulf region and the Carolinas have in the past been referred by many authors to the one species Exogyra costata Say, though some of them have been recognized as worthy of at least varietal rank and as having different stratigraphic ranges. However, in Texas the relative stratigraphic positions of Exogyra ponderosa Roemer and Exogyra costata Say have long been a matter of published record, and in New Jersey a similar restriction in the ranges of these two species has been recognized by Stuart Weller. ${ }^{1}$ Weller also recognized that the two species were similarly restricted in range in the South, basing his conclusions on collections from the Southern States, which he examined in the National Museum.

The purpose of this paper is to demonstrate that the representatives of the genus in these regions are separable into at least three species, two of which present well-characterized varieties, and to show that these forms are restricted in range in such a manner as to give them distinct value in correlation. The statements here given as to the range, distribution, and occurrence of the species and varieties of Exogyra in the eastern Gulf region and the Carolinas are based on a study of the collections in the National Museum and on personal field observations, except as otherwise stated.

\section{DEFINITION OF THE GENUS.}

The genus Exogyra is a member of the family Ostreidæ, superfamily Ostracea. It is distinguished from Ostrea and Gryphæa, the other principal genera of the family, chiefly by its spirally curved beaks. The genus was first described by Say, ${ }^{2}$ the type being Exogyra costata Say. His description is as follows:

Shell inequivalve, inequilateral; cicatrix one, large, deeply impressed, subcentral; inferior valve convex, attached, umbo spiral, spire lateral, prominent, hinge with two parallel, transverse grooves; superior valve discoidal operculiform, umbo not promipent, revolving spirally within the margin, hinge with a single groove on the edge.

1 The Cretaceous paleontology of New Jersey: New Jersey Geol. Survey, Paleontology, vol. 4, text, 1907, pp. 456-460.

2 Say, Thomas, Am. Jour. Sci., 1st ser., vol. 2, 1820, p. 43. 
The several generic characters described by Say may be seen by referring to the illustrations in this paper as follows:

Relative sizes of lower and upper valves.-Lower valves, Plate XIII, figure 1, and Plate $\mathrm{XV}$, figure 1. Upper valves, respectively, of same individuals, Plate XIII, figure 2, and Plate XV, figure 2.

Character and position of cicatrix (adductor scar).-Lower valve, Plate XIX, figure 2. Upper valve, Plate XV, figure 3.

Characters of left (lower) valve.-Convexity, Plate XIII, figure 7, and Plate XVI, figure 4. Examples of scar of attachment, Plate XIII, figures 1, 3, 4, 7. Position and spiral character of umbo (beak), Plate XIII, figures 5, 6, 7. Character of hinge, Plate XIX, figure 2.

Characters of right (upper) valve.-Shape, Plate XV, figures 2, 3. Position and spiral character of umbo (beak), Plate XV, figure 2. Character of hinge, Plate XV, figure 3.

\section{GEOLOGIC RANGE OF THE GENUS.}

The genus Exogyra ranges in time from the Upper Jurassic to the close of the Cretaceous period. In the eastern Gulf region, however, the genus is known only in the Upper Cretaceous beds, its range here being from the base of the Eutaw formation upward to the top of the Cretaceous. (See fig. 1, p. 23.) The formations embraced in this range are the Eutaw formation (including the Tombigbee sand member), the overlying Selma chalk, and the nonchalky marine equivalents of the Selma chalk. The latter, in northern Mississippi, comprises a part of the Tombigbee sand member of the Eutaw formation and all of the Ripley formation; in eastern Alabama and Georgia it comprises the Ripley formation.

In the Carolinas the range is somewhat more restricted than in the eastern Gulf region, the genus first making its appearance in beds toward the upper part of the Black Creek formation, which correspond approximately to the basal beds of the Selma chalk in its type region, and ranging upward through the remainder of the Black Creek strata and through all the overlying Peedee sand or to the top of the Cretaceous.

\section{GENERAL DESCRIPTION OF THE SPECIES AND VARIETIES.}

In the region under consideration three species of Exogyra have been recognized, two of which present variations of sufficient constancy to rank as varieties.

Exogyra upatoiensis sp. nov. has been found at one horizon only, and its known geographic range along the strike is only about 8 miles. Its horizon is within a few feet of the base of the Eutaw formation in eastern Alabama and western Georgia, and is the lowest horizon at which the genus has been found east of Mississippi River.

In shape and general proportions the species is similar to the other members of the genus from this region, but it is much smaller, the largest specimens in the collections not exceeding 21 inches in length. The lower or larger (left) valve is marked on its outer surface by numerous fine, closely set, bifurcating, radiating costæ, which present great irregularity as regards shape, size, and prominence, this peculiar ornamentation constituting the chief distinguishing character of the species.

The original of Exogyra ponderosa, described by Roemer, ${ }^{1}$ is from the vicinity of New Braunfels, Tex. The species as described is characterized by the ponderous size of the adult specimens, by the faint development of the radiating costæ, and by the rather strong development of concentric imbricating lamellæ. However, among a number of specimens collected by Stanton from the type locality are some with fairly well developed irregular costæ corresponding closely to those on the varietal form of the species from the eastern Gulf region (Exogyra ponderosa var. erraticostata).

The specimens from the eastern Gulf region and the Carolinas referred to Exogyra ponderosa agree in all their essential characters with Roemer's species. However, in addition to the

1 Roemer, Ferdinand, Texas, Bonn, 1849, pp. 395-396; Die Kreidebildungen von Texas, Bonn, 1852, pp. 71-72. 
characters described by him, many of the specimens have on the beaks of the larger valves small regularly arranged costæ extending from near the tip of the beaks backward over the surface of the shell for one-half to three-quarters of an inch, and some of them have a series of more or less strongly developed, sharp to round ridged costæ, which extend backward from the beak to a maximum distance of 5 inches, and which are strikingly irregular as regards their prominence, shape, and distribution. That these are variations within the species is proved by the fact that specimens showing all gradations from those entirely devoid of radiating costæ to those possessing the distinctly developed irregular costæ may in places be obtained from the same horizon. Although the two extremes are connected by forms showing all intermediate gradations, the striking difference in appearance between the noncostate forms and those with the well-developed irregular costæ seems to justify the adoption of a distinguishing designation for the latter, and the name Exogyra ponderosa var. erraticostata is therefore proposed.

The original of Exogyra costata was deseribed by Say ${ }^{1}$ from the Cretaceous of New Jersey. The exact locality from which the type was obtained is not known but is believed by Weller ${ }^{2}$ to have been Mulica Hill, a Navesink marl (Monmouth group) locality.

The species is characterized by the presence on the larger valve of regularly arranged, prominent, radiating, entire or bifurcating costæ, which, except on large, overgrown individuals, extend from the beak to the margin of the shell. These costæ vary in their greatest width on different individuals from 3 to 8 millimeters. In general, the costæ are widest in specimens occurring in the lower beds of the stratigraphic range of the species and grow narrower in those in successively higher beds to the upper limit of the range, but there are exceptions to the rule. A distinct varietal form of the species, and one which may perhaps be deserving of specific rank, is characterized by rather weak, regularly arranged, radiating costæ, interrupted by regularly distributed concentric depressions or undulations in such a manner as to give to the surface of the shell a checkered or cancellated appearance. For this form the name Exogyra costata var. cancellata is proposed.

\section{GEOLOGIC AND GEOGRAPHIC RANGE.}

\section{EASTERN GULF REGION AND THE CAROLINAS.}

In Plate XII the known ranges in the Atlantic and Gulf Coastal Plain of the species and varieties of Exogyra described in this paper are shown diagrammatically.

The known range of Exogyra upatoiensis sp. nov. in the eastern Gulf region is very slight, both stratigraphically and geographically, the species apparently being restricted to a stratum a few feet thick near the base of the Eutaw formation in eastern Alabama and western Georgia, the known linear extent of which does not exceed 8 miles. Specimens have been collected at three localities. Outside the eastern Gulf region the species is known from but one locality. In a well boring at Charleston, S. C., it was obtained from samples representing the depths 1,974 to 2,007 feet.

Exogyra ponderosa Roemer makes its first appearance near the base of the Tombigbee sand member of the Eutaw formation in the Chattahoochee region and ranges upward to about the middle of the Selma chalk and its corresponding nonchalky marine equivalents to the northward and eastward. In northern Mississippi these nonchalky equivalents consist chiefly of glauconitic, more or less calcareous sands, which constitute a part of the Tombigbee sand member of the Eutaw formation. In eastern Alabama and Georgia they consist of marine sands, clays, and marls, making up the lower one-third or one-half of the Ripley formation. The species has been obtained from 64 authentic localities scattered throughout a belt extending from Chattahoochee County, Ga., through Alabama and Mississippi to Henderson County, Tenn., a distance of about 375 miles, but by detailed collecting this number could be multiplied many times.

1 Say, Thomas, Am. Jour. Sci., 1st ser., vol. 2, 1820, p. 43.

2 Weller, Stuart, The Cretaceous paleontology of New Jersey: New Jersey Geoi. Survey, Paleontology, vol. 4, text, 1907, pp. 456-458. 
In North Carolina the species is restricted to the marine invertebrate-bearing beds forming the upper part of the Black Creek formation. It has been collected from four localities distributed along a linear distance of approximately 35 miles. The varietal form of the species, Exogyra ponderosa var. erraticostata var. nov., has approximately the same range and distribution as the typical form. This variety has been collected from 24 authentic localities in the eastern Gulf region and from two localities in the Black Creek formation of the Carolinas. Specimens questionably referred to this variety have been found at two localities in North Carolina in beds near the base of the overlying Peedee sand, indicating a slightly higher range than the known range of the variety in the eastern Gulf region.

Exogyra costata Say ranges from just above the upper limit of the range of Exogyra ponderosa Roemer, through the upper half of the Selma chalk and its nonchalky equivalents which include all of the Ripley formation of northern Mississippi, and the upper one-half or two-thirds of the Ripley formation of eastern Alabama and Georgia. Apparent exceptions to this limit of range are a few specimens found in the Exogyra ponderosa zone, which appear to approach rather closely to the typical costate forms, but all of which are smaller and differ slightly in form, shape, and arrangement of costæ from well-developed typical specimens. These are probably the ancestors of the true Exogyra costata of higher horizons. Geographically this species occurs in a belt south and west of that occupied by Exogyra ponderosa, extending from Macon County, Ga., westward through Alabama and northward through Mississippi to the Tennessee State line, a distance of 400 miles. The collections studied include specimens from 81 localities, but this number could be greatly increased were the region covered in detail.

In the Carolinas the species ranges through the Peedee sand. It has been obtained from 28 localities, distributed in a belt extending from Peedee River in South Carolina northeastward to the southern part of Pitt County, N. C., a distance of approximately 150 miles.

Exogyra costata var. cancellata var. nov. makes its first appearance approximately coincident with the initial appearance of the typical, strongly costate forms, the horizon of both being just above the upper limit of the range of Exogyra ponderosa Roemer. In the lowermost beds of its stratigraphic range, especially in Mississippi, this variety appears to exceed numerically the typical costate forms. In the successively higher beds it appears to decrease in numbers and is entirely absent, so far as known, from the upper 50 or 75 feet of Cretaceous strata in Mississippi and western Alabama and probably from a greater thickness in the Chattahoochee region.

This varietal form has been collected from 27 localities in the eastern Gulf region. Of these localities 26 are distributed through a belt lying south and west of that in which Exogyra ponderosa Roemer occurs and extending from Johnsons Hill, 4 miles north of Lumpkin, in Stewart County, Ga., westward through Alabama and northward through Mississippi to 7 miles east of Lexington, Henderson County, Tenn., a distance of approximately 400 miles. The twenty-seventh locality is near Cairo, Ill., where one specimen was found in an excavation for one of the piers of the Illinois Central Railroad bridge over Ohio River. (See p. 18.)

In North Carolina the variety has been obtained from four localities only, the horizon in each place being toward the basal part of the Peedee sand.

\section{NEW JERSEY.}

Both Exogyra ponderosa Roemer and Exogyra costata Say have been recognized in the Upper Cretaceous deposits of New Jersey. According to Weller ${ }^{1}$ they are here restricted in range in the same manner as their southern representatives. Exogyra ponderosa occurs only in the Marshalltown clay marl, which is next to the highest of the formations of the Matawan group; and Exogyra costata occurs throughout the Monmouth group, which overlies the Matawan group. So far as known the two species do not overlap in the New Jersey section and hence they afford a valuable means of correlation.

1 Weller, Stuart, The Cretaceous paleontology of New Jersey: New Jersey Geol. Survey, Paleontology, vol. 4, text, 1907, pp. 456-460. 


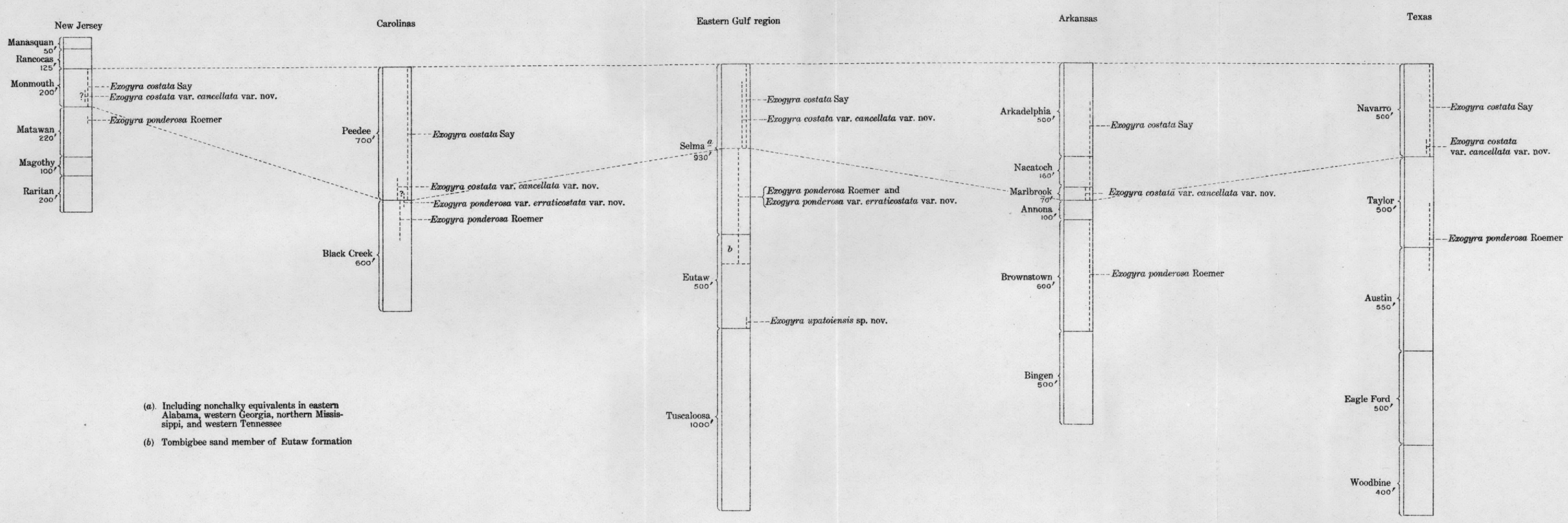

RANGES IN THE ATLANTIC AND GULF COASTAL PLAIN OF THE SPECIES AND VARIETIES OF EXOGYRA DESCRIBED IN THIS PAPER 



\section{WESTERN GULF REGION.}

In the western Gulf region the genus ranges from the Fredericksburg group of the Lower Cretaceous to the top of the Upper Cretaceous. The species common to the eastern Gulf region, however, do not occur lower than the Austin chalk. All the species and varieties occurring in the Upper Cretaceous deposits of the eastern Gulf region, except Exogyra upatoiensis sp. nov., are known in the Upper Cretaceous deposits of the western Gulf region. The information available in the literature, that afforded by the collections in the National Museum, and that obtained by the writer in his field studies, give good grounds for the belief that the range restrictions in the two regions are analogous.

In Arkansas and northeastern Texas Exogyra ponderosa Roemer and Exogyra ponderosa var. erraticostata, the former in abundance, oceur in the Brownstown marl. Exogyra costata Say occurs in the overlying Marlbrook marl, Nacatoch sand, and Arkadelphia clay. (See Pl. XII.) Exogyra costata var. cancellata var. nov. occurs abundantly in the Marlbrook marl.

In Texas the species Exogyra ponderosa Roemer is abundant in places in the upper part of the Austin chalk and in the basal beds of the overlying Taylor marl. A few specimens of Exogyra ponderosa var. erraticostata have been found in the basal part of the Taylor marl. Specimens in the National Museum referable to the last-named variety were collected in 1895 by Vaughan and Stanton, from beds that are regarded as synchronous with the Taylor marl, near San Carlos, Presidio County, Tex. ${ }^{1}$ These specimens (U. S. Geol. Survey coll. 1467 and field No. 297) were identified by Stanton as a variety intermediate between Exogyra costata Say and Exogyra ponderosa Roemer. Exogyra costata Say is a characteristic species of the Navarro and its equivalent, the "Webberville" formation, of Texas. Exogyra costata var. cancellata var. nov. occurs in beds probably representing the lower part of the Navarro formation near Cooper, Delta County, Tex., and in cuts of the Houston \& Texas Central Railroad 4 and $4 \frac{1}{2}$ miles, respectively, east of Crandall, Kaufman County, Tex. The genus has not been reported from the middle and upper parts of the underlying Taylor marl, and for this reason the upper limit of the range of Exogyra ponderosa Roemer and the lower limit of the range of Exogyra costata Say are not known.

MEXICO.

One specimen of Exogyra ponderosa Roemer from Mexico is in the National Museum collections. It was obtained by White and Stanton from a locality across the Rio Grande from Presidio, Tex. (U. S. Geol. Survey coll. 622). The beds were correlated by Stanton with the Taylor marl. (See p. 48.)

Exogyra costata Say has been described from so-called lower Senonian beds exposed in the vicinity of Cardenas, State of San Luis Potosi, Mexico, by Dr. Emilio Böse, whose figured specimens agree closely in the surface sculpture of the lower valve with the coarsely costate variety occurring near the base of the Exogyra costata zone in the eastern Gulf region. (See Pl. XVII, fig. 2.) They differ from the latter, however, in the sculpture of their upper valves, the concentric growth projections being coarser, more widely separated, and fewer in number in the Mexican specimens. Three specimens (U. S. Geol. Survey coll. 4129), which prove to be the variety Exogyra costata var. cancellata var. nov., were brought from Mexico by Stanton in 1906. They were given to him at San Luis Potosi and were said to have been collected near Ciudad del Maiz, State of San Luis Potosi.

UTAH.

In Utah, "east of Impracticable Ridge," specimens of Exogyra have been obtained from beds now known to belong to the Colorado group, and have been referred by White ${ }^{2}$ to Exogyra ponderosa (U. S. Nat. Mus. No. 13417). Although not typical, the specimens are nearer to this species than to any other described form, and until better collections have been made and the variations noted they may be considered correctly identified.

1 Vaughan, T. W., Reconnaissance in the Rio Grande coal fields of Texas: Bull. U. S. Geol. Survey No. 164, 1900, pp. 77-82.

2 White, C. A., Rept. U. S. Geog. Surveys W. 100th Mer., vol. 4, pt. 1, 1877, p. 172, PI. XIV, figs. 1 a-c. 


\title{
SYSTEMATIC DESCRIPTIONS.
}

Genus EXOGYRA Say.

\author{
Exogyra upatoinsis sp. nov.
}

Plate XIII, figures 1, 2, 3, 4 .

Description.-Shell small and thin as compared with other members of the genus in the region; subcircular to subovate in outline; dimensions of a medium-sized individual, length 33 millimeters, height 35 millimeters, convexity 18 millimeters (Pl. XIII, fig. 1); dimensions of a large individual, length 52 millimeters, height 55 millimeters, convexity 43 millimeters (PI. XIII, fig. 4). Left or lower valve much larger than right valve, strongly convex; attached in proximity of beak to an external object, the scar of attachment generally large and causing much distortion of the shell; the object of attachment is frequently the shell of another mollusk, the sculpture of which is distinctly impressed on some specimens of Exogyra (Pl. XIII, fig. 1); apical portion spirally coiled within the marginal outline of the shell, the coils including 1 to 2 volutions; hinge with ligamental groove broad, deeply impressed, paralleled above by a narrow, shallow groove, both grooves curved to conform to the spiral twist to the shell; posterior to the larger groove a broad shallow, striated depression; adductor scar distinct; surface ornamented with numerous fine, narrow, frequently bifurcating costæ, characterized by their irregularity as regards shape, size, and prominence (Pl. XIII, figs. 1 and 4); an umbonal ridge more or less clearly defined extends from the beak in a curve conforming to the spiral twist of the shell to the lower posterior margin-but this ridge in some specimens is interrupted in proximity to the beak by the scar of attachment; along the umbonal ridge the costx bifurcate more numerously than elsewhere (PI. XIII, fig. 1); toward the margin of the larger individuals the costæ become more irregular and weaker, in some specimens disappearing entirely; concentric growth lines are present in smaller individuals, and toward the margin of larger individuals these develop into prominent imbricating lamellæ (Pl. XIII, fig. 4). Upper or right valve, flat or slightly concave, operculiform, subcircular, or subovate in outline, with nearly flat, spiral twist, the beak being well within the margin; beak depressed, not prominent; this valve inclosed within and slightly depressed below the projecting margin of the lower valve; hinge with broad deeply impressed ligamental groove, curved to conform to the spiral twist of the shell, the upper margin of the groove finely crenulated; posterior to the groove a striated protuberance occupies a position in apposition to the similarly striated depression on the left valve; surface marked by fine concentric growth lines which toward the margin are produced into thin projecting lamellæ, separated by deep, narrow depressions.

Geologic occurrence.-Known only from beds near the base of the Eutaw formation in the Chattahoochee region (Alabama and Georgia), and from a deep well at Charleston, S. C.

Localities.-The species has been obtained from four localities as follows:

U. S. Geol. Survey colls. 5373, 5377.-Bluff on Upatoi Creek below bridge of Columbus-Cusseta road, 7 miles southeast of Columbus, in Chattahoochee County, Ga. Near base of Eutaw formation.

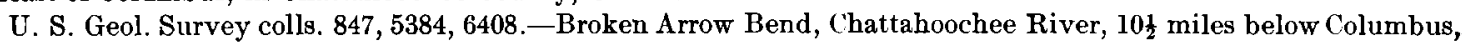
Ga. Near base of Eutaw formation.

U. S. Geol. Survey coll. 5385.-Chattahoochee River, one-half mile below Broken Arrow Bend. Near base of Eutaw formation.

U. S. Geol. Survey coll. 7778.-Deep well of the Charleston Consolidated Railway \& Lighting Co., Charleston, S. C., from a sample representing the depths 1,974 to 2,007 feet.

\section{Exogyra PONDEROSA Roemer.}

Plate XIII, figures 5, 6, 7; Plate XIV; Plate XV, figures 1, 2, 3.

1849. Exogyra ponderosa Roemer, Texas, p. 395.

1852. Exogyra ponderosa Roemer, Kreidebildungen von Texas, pp. 71-72, Taf. 9, figs. 2 a-b.

1853. Exogyra ponderosa Shumard, Marcy's Exploration of the Red River, La., pp. 204-205.

1857. Exogyra costata (var.) Conrad, U. S. and Mex. Boundary Survey, vol. 1, pt. 2, p. 154, Pl. VIII, fig. 3, Pl. IX, fig. 1 . 
1869. Ostrea torosa Coquand (in part), Monographie du genre Ostrea, terrain crétacé, Paris, p. 38, P1. IX, figs. 1,2 , and 3 .

1870. Exogyra ponderosa Credner, Zeitschr. Deutsch. geol. Gesell., vol. 22, p. 229.

1875. Exogyra ponderosa White, Rept. Geog. Surveys W. 100th Mer., vol. 4, pt. 1, p. 172, Pl. XIV, figs. 1 a-c.

1884. Exogyra ponderosa White, Fourth Ann. Rept. U. S. Geol. Survey, p. 306, Pl. L, figs. 1-2.

1885. Exogyra costata Whitfield (in part), Mon. U. S. Geol. Survey, vol. 9, pp. 39-41, Pl. VI, figs. I-2. Also Paleontology of New Jersey, vol. 1, 1886, pp. 39-41, Pl. VI, figs. 1-2.

1893. Exogyra ponderosa Stanton, Bull. U. S. Geol. Survey No. 106, pp. 65-66, PI. VII, figs. 1 and 2.

1901. Exogyra ponderosa Hill, Twenty-first Ann. Rept. U. S. Geol. Survey, pt. 7, Pl. XLV, fig. 1.

1902. Exogyra ponderosa Hill and Vaughan, Austin folio (No. 76), Geol. Atlas U. S., U. S. Geol. Survey, illustration sheet, fig. 46 .

1906. Exogyra ponderosa Veatch, Prof. Paper U. S. Geol. Survey No. 46, Pl. IX.

1907. Exogyra ponderosa Weller, New Jersey Geol. Survey, Paleontology, vol. 4, text, pp. 458-460, P1. XIVII, fig. 2.

Description.-- Shell of adult very thick and ponderous, in outline subcircular to extended subovate; dimensions of an adult individual, length 111 millimeters, height 177 millimeters, convexity 94 millimeters (Pl. XIV); dimensions of a medium-sized specimen, length 97 millimeters, height 112 millimeters, convexity 60 millimeters ( $P$ l. XV, fig. 1). Left or lower valve much larger than right valve, strongly convex; attached in proximity to beak to external object, this part of the shell often very much deformed by scar of attachment; apical portion of shell spirally coiled within the marginal outline of the shell; hinge with ligamental groove broad, deeply impressed, paralleled on the upper side by a rather faintly developed, narrow shallow groove, both grooves curved to conform to spiral twist of shell; posterior to the larger groove a broad, shallow, pitted or striated depression; surface of shell marked by thin, rather prominent, concentric, imbricating growth lamellæ, with intermediate fine growth lines; costæ either entirely absent or small, regularly arranged costæ present in proximity to beak and extending back from beak one-half to three-fourths inch (Pl. XIII, figs. 5-7), or, in addition to the preceding, very faint irregular costæ extending back to varying distances away from beak; a more or less clearly defined umbonal ridge extends from the beak backward, in a curve conforming to the spiral twist of shell, to the lower posterior margin, usually, however, becoming rounder and less clearly recognizable toward the margin (Pl. XV, fig. 1). Upper or right valve flat or slightly concave, operculiform, subcircular or subovate in outline, with a nearly flat, spiral twist, the beak being well within the margin; beak depressed, not prominent; this valve inclosed within and slightly depressed below the projecting margin of the lower valve; hinge with broad, deeply impressed ligamental groove curved to conform to the spiral twist of shell, the upper margin of the groove finely crenulated (Pl. XV, fig. 3); posterior to the groove a striated protuberance occupies a position in apposition to the similarly striated depression on the left valve; in proximity to the beak the surface is marked by numerous fine, concentric growth lines, which away from the beak toward the margins are produced into thin projecting lamellæ, separated by deep, narrow depressions.

Geologic occurrence.--In the Chattahoochee region (Alabama-Georgia) the species makes its first appearance near the base of the Tombigbee sand member of the Eutaw formation. It is common in the upper one-fourth to one-half of the Tombigbee sand in western Georgia, Alabama, and as far north in Mississippi as Monroe or Itawamba County, and in that part of the Tombigbee sund which in northern Mississippi represents the time equivalent of the basal part of the Selma chalk. From the Tombigbee sand it ranges upward to about the middle of the Selma chalk where the latter is most fully developed in western Alabama and east-central Mississippi; and is present in the corresponding nonchalky marine equivalents of the lower half of the Selma chalk in eastern Alabama and in Georgia, these equivalents constituting the lower one-third or one-half of the Ripley formation of this region. The upper limit of the range of the species is represented in Plates IX and X by red line 2.

In North Carolina the species occurs in the upper marine invertebrate-bearing beds of the Black Creek formation. 
In New Jersey the species occurs in the Marshalltown clay marl of the Matawan gioup.

In Arkansas and northeastern Texas the species occurs abundantly in the Brownstown marl.

In Texas the species is abundant in places in the upper part of the Austin chalk and in the lower part of the overlying Taylor marl; it is also fairly abundant in places in the Anacacho formation, which is the time equivalent in southwestern Texas of part or all of the Taylor marl.

Specimens considered referable to this species have been obtained from two localities outside of the Atlantic and Gulf Coastal Plain. One of the localities is represented by a specimen in the National Museum labeled as follows: "U. S. G. S. loc. No. 622, across the Rio Grande from Presidio, Tex., near top of shales. Collected by C. A. White and T. W. Stunton." Stanton ${ }^{1}$ compares the horizon where this was found with that of the invertebrate-bearing beds near San Carlos, Presidio County, Tex., which he regards as synchronous with a part of the Taylor marl.

The second locality is represented by several specimens, referred to this species by White, ${ }^{2}$ which were obtained "east of Impracticable Ridge, Utah," from beds now known to belong to the Colorado group. The figured specimen is in the National Museum (U.S. Nat. Mus. Cat. No. 13417) and has been examined by the writer. It is not a typical representative of the species, but is nearer to it than to any other described species. Until more specimens have been obtained from this locality and their variations noted, it is, perhaps, best to regard it as referable to this species.

Localities.-In the eastern Gulf region the species has been collected from 64 localities distributed along a belt 10 to 20 miles in width, extending from Chattahoochee County, Ga., through Alabama and Mississippi to McNairy County, Tenn. The trend of this belt may be seen by referring to the map (P1. IX); the area embraced by the belt is included between the dotted line indicated by the red letter $P$ and the red line 2. Detailed descriptions of all the localities accompany the tables (pp. 24-25). Some of the more typical localities are the following:

U. S. Geol. Survey coll. 5379.-Seaboard Air Line Railway, $2 \frac{1}{2}$ miles northwest of Cusseta, Chattahoochee County, Ga. Tombigbee sand member of Eutaw formation.

U. S. Geol. Survey coll. 5388.-Big Bend, Chattahoochee River, $24 \frac{1}{2}$ miles below Columbus, on the A labama side of the river. Tombigbee sand member of Eutaw formation.

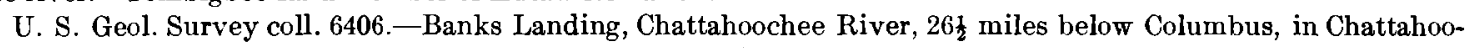
chee County, Ga. Tombigbee sand member of Eutaw formation.

U. S. Geol. Survey colls. 844, 5392, 6405.-Blufftown, Chattahoochee River, 31 $\frac{1}{4}$ miles below Columbus, in Chattahoochee County, Ga. Tombigbee sand member of Eutaw formation.

U. S. Geol. Survey coli. 6827.-Cut of Central of Georgia Railway 5 miles southwest of Seale, Russell County, Ala. Tombigbee and member of Eutaw formation.

U. S. Geol. Survey coll. 6820.-Conecuh Falls, Union Springs, Bullock County, Ala. Ripley formation near top of Exogyra ponderosa zone.

U. S. Geol. Survey colls. 273, 6425a.-Choctaw Bluff, Warrior River, 4 miles south of Eutaw, Greene County, Ala. Top of Tombigbee sand member of Eutaw formation.

U. S. Geol. Survey coll. 6432.-Warrior River, Hatchs Bluff, $7 \frac{1}{2}$ miles above Demopolis (by the river), in Hale County, Ala. Selma chalk (near top of Exogyra ponderosa zone).

U. S. Geol. Survey colls. 282, 6451a-c, 6414, 6918.-Plymouth Bluff, Tombigbee River, 4 to 5 miles northwest of Columbus, Lowndes County, Miss. Tombigbee sand member of Eutaw formation.

U. S. Geol. Survey coll. 6880.-Allen Gavin place, 12 miles east of Brookville, Noxubee County, Miss. Selma chalk (near base).

U. S. Geol. Survey coll. 6925.-Bluff on Tombigbee River at Aberdeen, Monroe County, Miss. Tombigbee sand member of Eutaw formation.

U. S. Geol. Survey colls. 6886-6888.-One mile west of Cotton Gin Port, Monroe County, Miss. Top of Tombigbee sand member of Eutaw formation and base of Selma chalk.

U. S. Geol. Survey coll. 6892.-Gullies on Erskine Miller's place near Black Oak Grove church, 7 miles northeast of Okolona in Monroe County, Miss. Selma chalk, Exogyra ponderosa zone.

U. S. Geol. Survey colls. 6458b, 6911.-Hare's old mill site on Big Brown Creek. 9 miles east of Booneville, Prentiss County, Miss. Tombigbee sand member of Eutaw formation. (Probably corresponds approximately to Mortoniceras subzone.)

1 Bull. U. S. Geol. Survey No. 164, 1900, p. 82.

White, C. A., Rept. U. S. Geog. Surveys W. 100th Mer., vol. 4, pt. 1, 1877, p. 172, Pl. XIV, figs. 1 a-c. 
C. S. Geol. Survey coll. 6455a.-Cut of Mobile \& Ohio Railroad south of station at Booneville, Prentiss County, Miss. Base of Selma chalk of northern Mississippi. (Within 50 to 100 feet of top of Exogyra ponderosa zone.)

U. S. Geol. Survey coll. 6457.--Bald spot near Geeville road, ] $\frac{1}{2}$ miles southwest of Booneville, Prentiss County, Miss. Selma chalk, near top of Exogyra ponderosa zone.

U.S. Geol. Survey coll. 6928.-Roadside exposure, one-quarter mile west of Adamsville, McNairy County, Tenn. Impure phase of Selma chalk. (Near top of Exogyra ponderosa zone.)

In North Carolina the species has been collected from 4 localities as follows:

U. S. Geol. Survey colls. 4144, 5347.-Blue Banks Landing, Tar River, 7 miles above Greenville, Pitt County. Black Creek formation.

U. S. Geol. Survey colls. 785, 5348.-Snow Hill, Greene County. Black Creek formation.

U. S. Geol. Survey coll. 4142.-Contentnea Creek, 6 miles below Snow Hill, Greene County. Black Creek formation.

U. S. Geol. Survey coll. 5353.-A A tger Hole Landing, Lenoir County. Black Creek formation.

Exogyra ponderosa var. erraticostata var. nov.

Plate XV, figure 4; Plate XVI, figures 1, 2.

Description.-In all its characters except the surface ornamentation of the left or lower valve this variety is essentially like the typical Exogyra ponderosa Roemer.

The surface of the left valve is characterized by the presence of fairly well defined, sharp to rounded, ridged, radiating costæ or plications which differ from the costæ on Exogyra costata Say in their generally weaker development and in their striking irregularity as regards size, shape, and distribution ( $\mathrm{Pl}$. XV, fig. 4). In proximity to the beak the shell is usually ornamented with small, regularly arranged costæ (such as are present on some specimens of Exogyra ponderosa Roemer, Pl. XIII, fig. 5), extending backward over the shell one-half to three-fourths of an inch (Pl. XVI, fig. 1) and merging into the irregular costæ just described, which characterize the variety. The irregular costæ extend backward 3 to 5 inches from the beak, becoming weaker in the direction of the margin; in the larger individuals there is usually a considerable part of the surface bordering the margin on which the costæ are either very faint or are entirely absent (Pl. XVI, fig. 1).

Remarks.-That this form is closely related to Exogyra ponderosa Roemer is proved by the fact that practically all gradations are found between specimens typical of the species, and the extremes of the variety. The specimen illustrated in Plate XVI, figure 1, represents one of the intermediate gradations; in this specimen the irregular costæ are rather strongly developed in front of the umbonal ridge on a part of the shell not showing in the illustration, for which reason it is referred to this variety.

Geologic occurrence.-In the eastern Gulf region Exogyra ponderosa var. erraticostata appears to be coextensive in its occurrence both stratigraphically and geographically with Exogyra ponderosa Roemer. It is present in the Tombigbee sand member of the Eutaw formation and ranges upward to about the middle of the Selma chalk, where the latter is most fully developed in western Alabama and east-central Mississippi, and is present in the corresponding nonchalky equivalents of this part of the Selma chalk in eastern Alabama and Georgia-that is, in approximately the lower one-third or one-half of the Ripley formation. The lower limit of its range is shown in Plates IX and X by the dotted line indicated by the red letter P and the upper limit by the red line 2. In the Carolinas the variety occurs in the marine invertebrate-bearing beds forming the upper part of the Black Creek formation, and it is present questionably in the extreme basal beds of the overdying Peedee sand.

From Weller's description ${ }^{1}$ of Exogyra ponderosa Roemer the variety is doubtless present in the Marshalltown clay marl of the Matawan group in association with the typical forms of the species.

In Arkansas and northeastern Texas the variety occurs in the Brownstown marl. Farther south in Texas it occurs in the basal part of the Taylor marl and it has been recognized in

1 Weller, Stuart, The Cretaceous paleontology of New Jersey: New Jersey Geol. Survey, Paleontology, vol. 4, 1907, text, pp. 160-462. $105^{\circ}-$ No. $81-14-4$ 
collections from beds near San Carlos, Presidio County, regarded as synchronous with a part of the Taylor marl. (U. S. Geol. Survey coll. 1467 and Stanton's field No. 297.) The last-named collection was made by Vaughan and Stanton. (See p. 45.)

Localities.-This variety has been obtained in the eastern Gulf region from 24 localities, detailed descriptions of which accompany the tables, pages 24-25 of this report. Some of the more typical localities are the following:

U. S. Geol. Survey colls. 5395, 6404.-Bluff on Chattahoochee River at Florence, Stewart County, Ga. Ripley formation, Exogyra ponderosa zone.

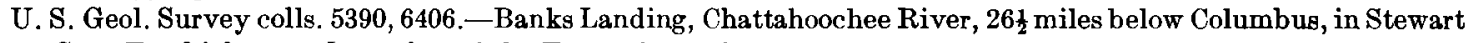
County, Ga. Tombigbee sand member of the Eutaw formation.

U. S. Geol. Survey coll. 6441.-Public road, $1 \frac{1}{2}$ miles east of Old Hamburg, Perry County, Ala. Top of Tombigbee sand member of Eutaw formation.

U. S. Geol. Survey colls. 6428b, 6932.-Erie Bluff, Warrior River, Greene County, Ala. Top of Tombigbee saud member of Eutaw. formation.

U. S. Geol. Survey coll. 6920.-Gullies near Plymouth Bluff, Tombigbee.River, 4 or 5 miles northwest of Columbus, Miss. Base of Selma chalk.

U. S. Geol. Survey colls. 6886, 6888.- One mile west of Cotton Gin Port, Monroe County, Miss. Base of Selma chalk.

U. S. Geol. Survey coll. 6892.-Gullies on Erskine Miller's place, near Black Oak Grove church, 7 miles northeast of Okolona, Monroe County, Miss. Selma chalk, Exogyra ponderosa zone.

U. S. Geol. Survey coll. 6455.-Cut of Mobile \& Ohio Railroad south of Booneville, Prentiss County, Miss. Base of Selma chalk of northern Mississippi (within 50 to 100 feet of top of Exogyra ponderosa zone).

U. S. Geol. Survey coll. 6928.-Exposures in Selmer-Adamsville road, one-quarter mile west of Adamsville, McNairy County, Tenn. Impure phase of Selma chalk, near to top of Exogyra ponderosa zone.

The variety has been collected from the following localities in the Carolinas:

U. S. Geol. Survey coll.5366.--Iron Mine Landing, Black River, 51 miles above Wilmington, N. C. Near top of Black Creek formation.

U. S. Geol. Survey coll. 5372.--Hodge's old mill, $3 \frac{1}{2}$ miles southeast of Mullins, Marion County, S. C. Top of Black Creek formation.

In addition to these localities specimens which should perhaps be referred to this variety have been found on Cape Fear River at Donohue Creek Landing, $50 \frac{1}{3}$ miles above Wilmington, and at Kelly's Cove Landing, 46 miles above Wilmington, Bladen County, N. C., the beds from which they were taken being in each case stratigraphically near the base of the Peedee sand. This is a slightly higher range than the known range of the variety in the eastern Gulf region.

Exogyra costata Say.

Plate XVI, figures 3, 4; Plate XVII, figures 1, 2; Plate XVIII; Plate XIX, figures 1, 2, 3, 4; Plate XX, figure 1.

1820. Exogyra costata Say, Am. Jour. Sci., 1st ser., vol. 2, p. 43.

1828. Exogyra costata Morton, Jour. Acad. Nat. Sci. Philadelphia, 1st ser., vol. 6, p. 85, Pl. VI, figs. 1-4.

1830. Exogyra costata Morton, Am. Jour. Sci., lst ser., vol. 17, p. 284.

1834. Exogyra costata Morton, Synopsis of the organic remains of the Cretaceous group of the United States, pp. 5556, Pl. VI, figs. $1-4$.

1840. Exogyra costata Troost, Fifth Geol. Rept. Tennessee, p. 46.

1849. Exogyra costata Roemer [?], Texas, Bonn, 1849, p. 396.

1852. Exogyra costata Roemer [?], Kreidebildungen von Texas, Bonn, p. 72.

1857. Exogyra costata Conrad, Rept. U. S. and Mex. Boundary Survey, vol. 1, pt. 2, pp. 154-155, Pl. IX, fig. 2a-b, Pl. X, fig. 1 .

1858. Exogyra interrupta Conrad, Jour. Acad. Nat. Sci. Philadelphia, 2d ser., vol. 3, p. 330, Pl. XXXIV, fig. 15.

1858. Exogyra costata Emmons, Rept. North Carolina Geol. Survey, p. 278, fig. A.

1860. Exogyra costata Owen, Second Rept. Geol. Recon. Arkansas, Pl. VII, fig. 4.

1861. Exogyra costata Gabb, Synopsis of the Mollusca of the Cretaceous formation, p. 122.

1864. Exogyra costata Meek, Check list of the invertebrate fossils of North America, Cretaceous and Jurassic, Smith sonian Misc. Coll., vol. 7 (No. 177), p. 6.

1868. Exogyra costata Conrad, Cook's Geol. New Jersey, p. 374, fig. 1, p. 724.

1869. Ostrea torosa Coquand (in part), Monographie du genre Ostrea, terrain crétacé, Paris, p. 38, Pl. XIV, figs. 1-4, Pl. XV, figs. $1,2$.

1876. Exogyra costata Gabb, Proc. Acad. Nat. Sci. Philadelphia, 1876, p. 323. 
1884. Exogyra costata White, Fourth Ann. Rept. U. S. Geol. Survey, p. 304, Pl. LI, figs. 1-2, Pl. LVII, figs. 1-2. 1885. Exogyra costata Whitfield (in part), Mon. U. S. Geol. Survey, vol. 9, 1886, pp. 39-41, Pl. VI, figs. 1, 2. Also Paleontology of New Jersey, vol. 1, 1886, pp. 39-41, Pl. VI, figs. 1, 2.

1896. Exogyra costata Say, Bull. Am. Paleontology, vol. 1, p. 291 (No. 5, p. 21) (a reprint).

1901. Exogyra costata Hill, Twenty-first Ann. Rept. U. S. Geol. Survey, pt. 7, Pl. XLVII, figs. 1, 1a.

1902. Exogyra costata Hill and Vaughan, Austin folio (No. 76) Geol. Atlas U. S., U. S. Geol. Survey, illustration sheet, fig. 52 .

1906. Exogyra costata Böse, Bol. Mexico Inst. Geol., No. 24, pp. 51-54, Pl. VI, fig. 3, Pl. VII, fig. 1, Pl. VIII, figs. 2-3, Pl. IX, fig. 3 .

1906. Exogyra costata Veatch, Prof. Paper U. S. Geol. Survey No. 46, Pl. XI, fig. 2a-b.

1907. Exogyra costata Weller, New Jersey Geol. Survey, Paleontology, vol. 4, text, pp. 456-458, Pl. XLVII, fig. 1.

Description.-Shell of adult specimens thick and massive, becoming ponderous in some overgrown specimens; subcircular to subovate in outline; dimensions of an average-sized specimen, length 105 millimeters, height 115 millimeters, convexity 65 millimeters; the dimensions of the largest specimen in the collections, length 162 millimeters, height 200 millimeters, convexity 100 millimeters (Pl. XVIII); valves unequal. Left or lower valve much larger than right valve, convex, and attached in proximity to beak to an external object; the beak usually more or less deformed by the scar of attachment; apical portion of shell spirally coiled within the margin; hinge and other internal shell characters essentially the same as in Exogyra ponderosa Roemer; outer surface of shell characterized by regularly arranged, prominent, often rugged, radiating, entire or bifurcating costæ, which in typical normal specimens extend in curves conforming to the spiral $t$ wist of the shell from the beak to the margin; the costæ are separated by depressions which are usually narrower than the costæ themselves; in occasional nontypical specimens the costæ are weakly developed and in large overgrown individuals the costæ become faint or disappear entirely in the direction of the margin (PI. XVIII); in cross section the costæ vary in shape from semicircular to squarish; the costæ vary in maximum width on different adult individuals from 3 to 8 millimeters; many specimens are further ornamented by concentric, imbricating growth lamelæ, which vary greatly in prominence from mere growth lines to broad, thin, projections, in some specimens extending outward from the summits of the costæ in spinelike folds (Pl. XIX, fig. 1); in some specimens the summits of the costæ are ornamented with slight nodular protuberances (Pl. XIX, figs. 3 and 4); in most specimens there is a more or less distinctly marked umbonal ridge extending from the beak around to the posterior margin in a curve corresponding to the spiral twist of the shell; along the umbonal ridge the costæ bifurcate frequently, those in front and below the ridge extending with a slight backward curve to the lower margin, and those above and to the rear of the ridge extending with a strong, upward curve to the upper posterior margin. Upper or right valve flatly spiral, roughly disk-shaped or operculiform, the outer surface varying from slightly convex to slightly concave, the valve inclosed within and slightly depressed below the projecting margin of the lower valve; hinge and other internal shell characters essentially the same as in Exogyra ponderosa Roemer; beak depressed, not prominent; surface of shell ornamented with numerous concentric sharp-edged lamellæ, separated by narrow, deep depressions; radiating costæ absent or but faintly developed on most specimens but on some specimens are fairly prominent on upper posterior one-third of the shell surface (PI. XX, fig. 1).

Remarks. - The exact locality from which the type specimen of this species was taken is not known, but it is believed by Weller to have come from Mullica Hill, N. J., a Navesink marl (Monmouth group) iocality. In general this species occurs in beds stratigraphically higher than those in which the species Exogyra ponderosa occurs, but there are apparent exceptions. (See p. 44.)

The specimens taken from the base of the zone of Exogyra costata have in general a coarser surface ornamentation than those from higher horizons. (See p. 43.)

Geologic occurrence.-In the eastern Gulf region the species is generally distributed through the zone of Exogyra costata, which includes the Ripley formation (typical marine beds) of northern Mississippi, approximately the upper one-half of the Selma chalk, where this formation is most fully developed, and the upper one-half or two-thirds of the Ripley formation (typical 
marine beds) of eastern Alabama and Georgia. The lower limits of the range of typical specimens in the eastern Gulf region is shown in Plates IX and X by the red line 2.

In the Carolinas the species occurs throughout the Peedee sand.

In New Jersey the species is present in the Navesink marl and the Redbank sand, both formations of the Monmouth group.

In Arkansas the species ranges through the Marlbrook marl, the Nacatoch sand, and the Arkadelphia clay.

In Texas the species is a common fossil in the Navarro formation and its equivalent the "Webberville" formation.

In Mexico the species occurs in the Cardenas division of the so-called lower Senonian.

Localities.-In the eastern Gulf region the species has been collected from 81 localities distributed along a belt 10 to 20 miles wide, extending from Macon County, Ga., through Alabama and Mississippi, to the Tennessee State line. The trend of this belt may be seen by referring to the map, Plate IX; the area embraced by the belt is included between the red line 2 and the line marking the southern and western boundary of the Cretaceous area. Detailed descriptions of all the localities accompany the tables, pages 24-25. The following typical localities may be mentioned in detail:

U. S. Geol. Survey colls. 186, 389, 854, 6400.-Chattahoochee River at Eufaula, Ala. Ripley formation, Exogyra costata zone.

U. S. Geol. Survey coll. 6398.-Chattahoochee River, opposite the mouth of Burstahatchee Creek, $5 \frac{1}{2}$ mileg (by the river) above Eufaula, Ala. Ripley formation, near base of Exogyra costata zone.

U. S. Geol. Survey colls. 5375, 6418a-c,e-h,j.-Johnsons Hill, 4 miles north of Lumpkin, Stewart County, Ga. Ripley formation, Exogyra costata zone.

U. S. Geol. Survey colls. 6413, 6414.-Cuts of Seaboard Air Line Railway north of Renfroes, Stewart County, Ga. Ripley formation, Exogyra costata zone.

U. S. Geol. Survey colls. 6439, 6789.-Alabama River, Old Canton Landing, Wilcox County, Ala. Tongue of Selma chalk at top of Cretaceous.

U. S. Geol. Survey colls. 292, 6438.-Tombigbee River, Moscow Landing, about 14 miles below Demopolis, Sumtor County, Ala. Top of Selma chalk.

U. S. Geol. Survey coll. 6804.-Livingston-Epes road, $4 \frac{1}{4}$ miles northeast of Livingston, Sumter County, Ala. Selma chalk, Exogyra costata zone.

U. S. Geol. Survey coll. $6480 b, d, e, f$.-Six miles north of Scooba on Wahalak-Binnsville road, westward-facing slope of Wahalak Creek valley, Kemper County, Miss. Near top of Selma chalk.

U. S. Geol. Survey coll. 6479a-c.-Macon-Shuqualak road, 5 miles south of Macon, northward-facing slope of Running Water Creek, Noxubee County, Miss. Near top of Selma chalk.

U. S. Geol. Survey coll.6476. - Louisville road, 2 miles a little south of west of Macon, Noxubee County, Miss. Selma chalk, Exogyra costata zone.

U.S. Geol. Survey colls. 3186, 6843, 6844.-Gullies on grounds of Agricultural and Mechanical College at Starkville, Oktibbeha County, Miss. Top of Selma chalk.

U.S. Geol. Survey coll. 6863.--Six miles west of Tupelo, Miss., in gullies in field on westward-facing slope just north of Tupelo-Pontotoc road. Toward base of Exogyra costata zone.

U. S. Geol. Survey colls. 75, 546, 707, 6464.-Owl Creek, 3 miles northeast of Ripley, in Tippah County, Miss. Top of Ripley formation at type locality.

U. S. Geol. Survey coll. 6459._ "BaId Knob" on Joseph Reynolds place, 3 miles west of Corinth, Miss. Toward base of Exogyra costata zone.

The species has been obtained from 28 localities in the Carolinas. Several of the more notable localities are the following:

U. S. Geol. Survey coll. 4153.-Contentnea Creek, $1 \frac{1}{2}$ miles above Grifton, Pitt County, N. C. Peedee sand.

U. S. Geol. Survey coll. 4131. - Northeast Cape Fear River, right bank, $67 \frac{1}{2}$ miles above Wilmington, in Duplin County, N. C. Peedee sand.

U. S. Geol. Survey coll. 4133.--Johnsons Cove, Northeast Cape Fear River, right bank, 613 miles above Wilmington, in Duplin County, N. C. Peedee sand.

U. S. Geol. Survey coll. 3356.--Robinsons Landing, Cape Fear.River, right bank, 50 miles above Wilmington, in Bladen County, N. C. Peedee sand.

U. S. Geol. Survey coll. 4154.-Daniels Landing, Cape Fear River, right bank, 40 miles above Wilmington, in Bladen County, N. C. Peedee sand.

U. S. Geol. Survey coll. 3449.-Black Rock Landing, Cape Fear River, right bank, 37 miles above Wilmington, in Bladen County, N. C. Peedee sand. 
U. S. Geol. Survey coll. 4143.--Northeast Cape Fear River, Hilton Park, Wilmington, N. C. Top of Peedee sand. U. S. Geol. Survey coll. 4147.-Burches Ferry, Peedee River, right bank, 873 miles above Georgetown, in Florence County, S. C. (15 miles below Seaboard Air Line Ry. bridge). Peedee sand.

U. S. Geol. Survey coll. 4159.-Davis Landing, Peedee River, right bank, 71 miles above Georgetown, in Florence County, S. C. Peedee sand.

Exogyra costata var. canceli.ata var. nov.

Plate XX, figures 2, 3, 4; Plate XXI, figures 1, 2.

Description.-Shell of adult moderately thick; subcircular to subovate in outline: dimensions of an average specimen, length 92 millimeters, height 89 millimeters, convexity 41 millimeters; dimensions of a rather large specimen, length 117 millimeters, height 123 millimeters, convexity 58 millimeters (Pl. XXI, fig. 2). Left or lower valve much larger than right valve and strongly convex; attached in proximity of beak to an external object, the beak usually somewhat deformed by the scar of attachment; general form, hinge characters, and other internal shell characters essentially the same as in Exogyra costata Say; surface of shell ornamented with more or less distinct, low, bifurcating, nodular costæ, the nodes produced by concentric depressions regularly arranged in such a manner as to give to the surface of the shell a checkered or cancellated appearance (Pl. XX, figs. 2 and 3 ); the nodes on the costæ are in some specimens more prominently connected concentrically than in the direction of the radiating costæ, thus producing distinct concentric rilges (Pl. XX, fig. 4); in nontypical specimens the costæ are weakly developed and there is a corresponding strong devclopment of concentric growth lamellæ; in adult specimens the costæ, apparently without cxception, become faint and disappear in the direction of the margin, there being an area bordering the margin, varying in width, on which concentric imbricating lamellæ form the only ornamentation (Pl. XXI, fig. 2); extending from the beak to the posterior margin in a curve corresponding to the spiral twist of the shell there is a more or less distinctly defined, shallow, depressed area which broadens gradually in the direction of the margin (Pl. XXI, fig. 2); along the posterior margin of this depression, which perhaps corresponds to the umbonal ridge in Exogyra costata Say, the radiating costæ repeatedly bifurcate, those in front of this margin extending downward in the direction of the lower margin of the shell and those behind the margin extending upward in a rather sharp curve to the upper posterior margin of the shell. Upper or right valve operculiform, roughly ovate in outline and inclosed within the projecting margin of the lower valve (Pl. XXI, fig. 1); usually distinctly concave on outer surface and convex on inner surface; hinge and other internal characters essentially the same as in Exogyra costata Say; beak depressed, not prominent, with nearly flat spiral twist or coil; surface ornamented with numerous concentrically arranged sharp-edged lamellæ, separated by deep narrow depressions, the lamellæ being more prominent toward the outer margin of the shell, the inner, strongly concave portion of the surface being nearly smooth (Pl. XXI, fig. 1); costæ either absent or but very faintly developed toward postero-dorsal margin.

Remarks. - This variety has not previously been differentiated from the typical form of the species. However, it possesses a distinctive ornamentation, always recognizable, which certainly justifies its recognition as a variety; there is even a suggestion that the form developed parallel to rather than from Exogyra costata Say, in which case it should, perhaps, be given specific and not varietal rank.

Morton ${ }^{1}$ has described an oyster from New Jersey which he called Ostrea torosa, the ornamentation of which, as figured, suggests that it may have been an imperfect or distorted specimen of this variety. The specimen was later referred by Gabb ${ }^{2}$ to Exogyra costata. Weller, in his monograph on the Cretaceous paleontology of New Jersey, makes no mention whatever of the specimen, and probably it was not preserved and was not available for examination when his monograph was written.

${ }_{1}$ Morton, S. G., Synopsis of the organic remains of the ferruginous sand formation of the United States: Am. Jour. Sci., 1st ser., vol. 24, 1833, p. 130, Pl. X, fig. 1; Synopsis of tho organic remains of the Cretaceous group, 1834, p. 52, Pl. X, fig. 1.

2 Gabb, W. M., Synopsis of the Mollusca of the Cretaceous formation, 1861, p. 122. 
Geologic occurrence.-This variety makes its first appearance approximately coincident with the initial appearance of the typical, strongly costate forms; that is, at the base of the zone of Exogyra costata; it has not been found in association with typical specimens of Exogyra ponderosa Roemer. In the lowermost beds of its stratigraphic range, especially in Mississippi, it appears to exceed in numbers the trpical costate forms. In the successively higher beds it appears to decrease in numbers, and it is absent, so far as known, from the upper 80 or 100 feet of strata in Mississippi and western Alabama and probably from a somewhat greater thickness in the Chattahoochee region.

In the Carolinas the form occurs in the Peedee sand, the known localities being near the base of that terrane; that is, near the base of the zone of Exogyra costata.

Among the collections in the National Museum are specimens of this variety labeled as follows:

U. S. Geol. Survey coll. 288c.-Cretaceous (Middle marl), near St. Georges, Del. Collector, J. B. Marcou. [2 specimens.]

U. S. Geol. Survey coll. 286_-Cretaceous. New Egypt, N. J. Collector, J. B. Marcou. [12 or more specimens.]

U. S. Nat. Museum Cab. No. 21778. - New Jersey, part of O. N. Bryan collection, March 18, 1892.

The St. Georges specimens probably came from an exposure on or near the Chesapeake and Delaware Canal. The specimens from New Egypt are associated with Cucullæa antrosa Morton, Exogyra costata Say (typical), Gryphæa vesicularis Lamarck, Veniella conradi (Morton), Cardium spillmani Conrad, and Belemnitella americana (Morton); the collection probably came from a Monmouth horizon (possibly the Navesink marl of the Monmouth group) within several miles north or northwest of New Egypt, Ocean County; for according to the geologic map of New Jersey only strata of the Rancocas and Manasquan formations, from which no representatives of Exogyra have been reported, outcrop in the immediate vicinity of New Egypt. The collection has the aspect of a Navesink marl fauna.

In Arkansas the variety occurs abundantly in the Marlbrook marl.

In Texas the variety has been obtained from three localities, all of which are probably near the base of the Navarro formation. The first locality is one-half mile north of Cooper, Delta County (U. S. Geol. Survey colls. 4064 and 7509) and the second and third are 4 and $4 \frac{1}{2}$ miles, respectively, east of Crandall, Kaufman County (U. S. Geol. Survey coll. 7549).

Three typical specimens of this variety, brought from Mexico in 1906 by Dr. T. W. Stanton, were given to him at San Luis Potosi and were said to have been collected from a locality (U. S. Geol. Survey coll. 4129) near Ciudad del Maiz, State of San Luis Potosi.

Localities.-In the eastern Gulf region the variety has been obtained from 27 localities, detailed descriptions of which accompany the tables (pp. 24-25). Some of the more notable occurrences are the following:

U. S. Geol. Survey coll. 6418g-j.-Johnsons Hill, 4 miles north of Lumpkin on Lumpkin-Louvale road, Stewart County, Ga. Ripley formation, Exogyra costata zone.

U. S. Geol. Survey colls. 6413, 6414.-Cuts of Seaboard Air Line Railway, one-quarter to 11 miles north of Renfroes, Stewart County, Ga. Ripley formation, Exogyra costata zone.

U. S. Geol. Survey colls. 6790, 6792.-Alabama River, Rocky Bluff, about 1 mile above Prairie Bluff, Wilcox County, Ala. Ripley formation, within 80 to 100 feet of top of Cretaceous.

U. S. Geol. Survey coll. 6805.-Public road, 6 miles north of Livingston, Sumter County, Ala. Selma chalk, Exogyra costata zone.

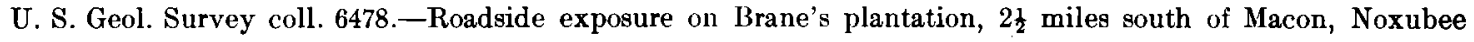
County, Miss. Selma chalk, Exogyra costata zone.

U. S. Geol. Survey coll. 6840.--Exposure in public road, 3 miles northwest of Macon, Noxubee County, Mise. Selma chalk, Exogyra costata zone.

U. S. Geol. Survey coll. 6862.-West Point-Cedar Bluff road, 1 mile east of Cedar Bluff near west end of bridge over Line Creek, Clay County, Miss. Selma chalk, Exogyra costata zone.

U. S. Geol. Survey coll. 6472.-Gullies south of Troy-Shannon road, 3 miles east of Troy, in Lee County, Miss. Selma chalk, Exogyra costata zone.

U. S. Geol. Survey coll. 6456.-Gullies near public road, $3 \frac{1}{2}$ miles northwest of Booneville, Prentiss County, Miss. Selma chalk near base of Exogyra costata zone.

U. S. Geol. Survey coll. 6459.-Bald Knob, Joseph Reynolds place, 3 miles west of Corinth, Alcorn County, Miss. Selma chalk, toward base of Exogyra costata zone. 
U.S. Geol. Survey coll. 6879.-Cut of Southern Railway, 24 miles west of Corinth, Alcorn County, Miss. Selma chalk, toward base of Exogyra costata zone.

U. S. Geol. Survey coll. 6927.-Selmer-Adamsville road, 3 miles west of Adamsville, McNairy County, Tenn. Impure phase of Selma chalk near base of Exogyra costata zone.

Specimen No. 8358 of the State Natural History Museum, Springfield, Ill. Excavation for pier of Illinois Central Railroad bridge near Cairo, Ill. Exogyra costata zone.

In North Carolina the variety has been obtained from the following four localities:

U. S. Geol. Survey coll. 3353.-Kellys Cove Landing, Cape Fear River, $46 \frac{1}{2}$ miles above Wilmington. Peedee sand (toward base).

U. S. Geol. Survey colls. 3450, 5370.-Indian Wells Landing, Cape Fear River, 41 miles above Wilmington. Peedee sand (toward base).

U. S. Geol. Survey colls. 3449, 5371. Black Rock Landing, Cape Fear River, 37 miles above Wilmington. Peedee sand (toward base).

U. S. Geol. Survey coll. 5367.-Near Sparkleberry Landing, Black River, 39 miles above Wilmington. Peedee sand (toward base). 

PLATE XIII. 


\section{PLATE XIII.}

Exogrra Upatolensis sp. nov. (p. 46).

Fraure 1.-Specimen with both valves attached, from basal beds of the Eutaw formation, Broken Arrow Bend, Chattahoochee River, $10 \frac{1}{2}$ miles below Columbus, Ga. (U. S. Geol. Survey coll. 5384). Shows ornamentation of left or lower valve and scar of attachment to a univalve shell.

2.-Same specimen as preceding, showing right or upper valve.

3.-Left valve of a nearly complete specimen from basal beds of Eutaw formation, bluff of Upatoi Creek, below bridge of Columbus-Cusseta road, 7 miles southeast of Columbus, in Chattahoochee County, Ga. (U. S. Geol. Survey coll. 5317). Shows character of ornamentation toward apical portion; apex somewhat distorted by scar of attachment to a univalve shell.

4.- - Large left valve from same locality as specimen shown in figure 1 (U. S. Geol. Survey coll.5384). Shows a weaker development of costæ than on preceding specimens, and scar of attachment to a bivalve shell.

EXogYra PONDERosa Roemer (p. 46).

Figure 5.-Specimen with both valves attached, from the Tombigbee sand member of the Eutaw formation (Exogyra ponderosa zone, Mortoniceras subzone); bluff at Blufftown, Chattahoochee River, 311 miles below Columbus, Ga. (U. S. Geol. Survey coll. 6405d). Shows development of small costæ on apical portion of shell.

6.- Same specimen as preceding, showing absence of costæ on all but apical portion.

7.-Another view of the same specimen. A small scar of attachment appears on the tip of the beak. 

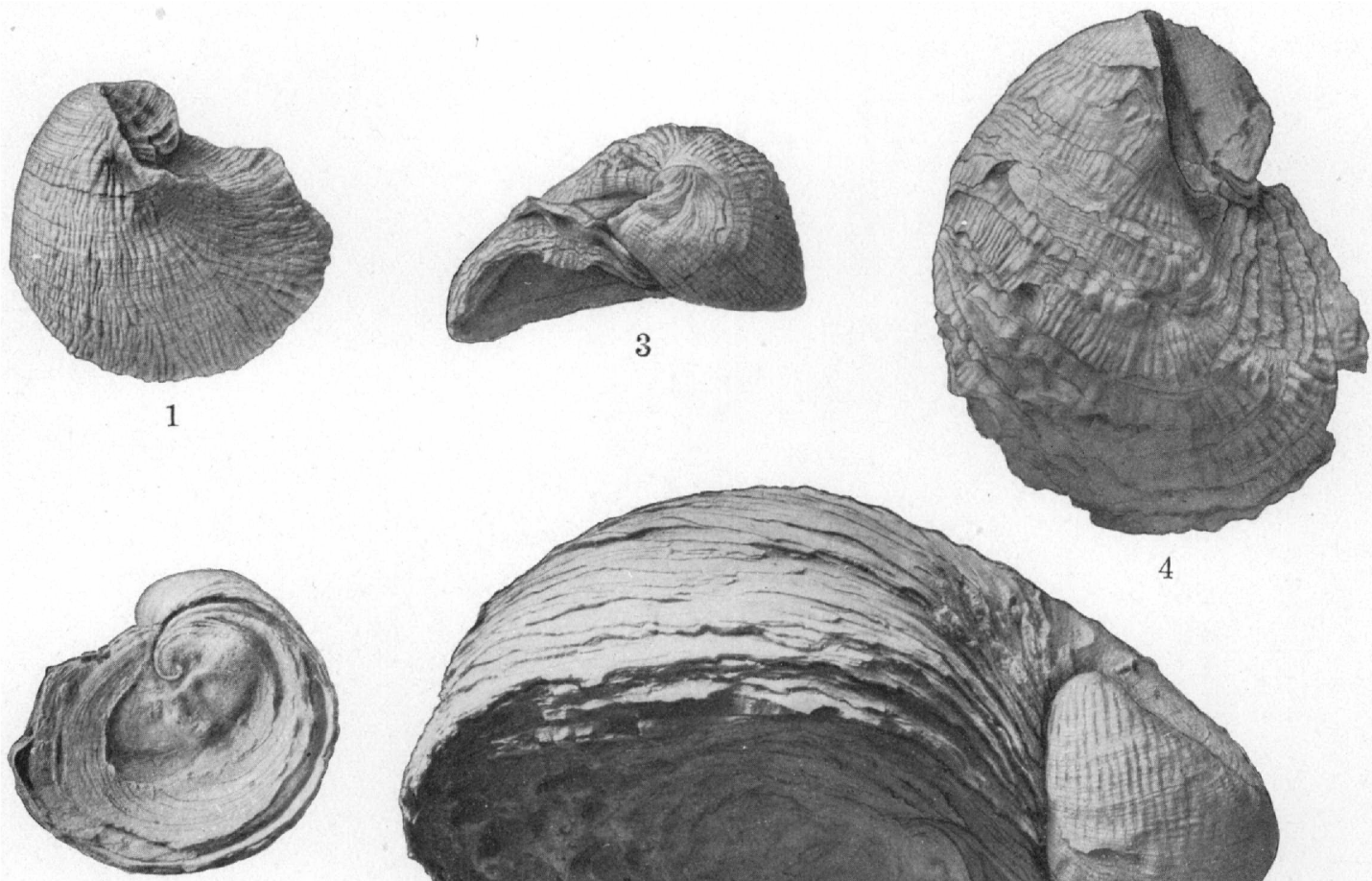

2
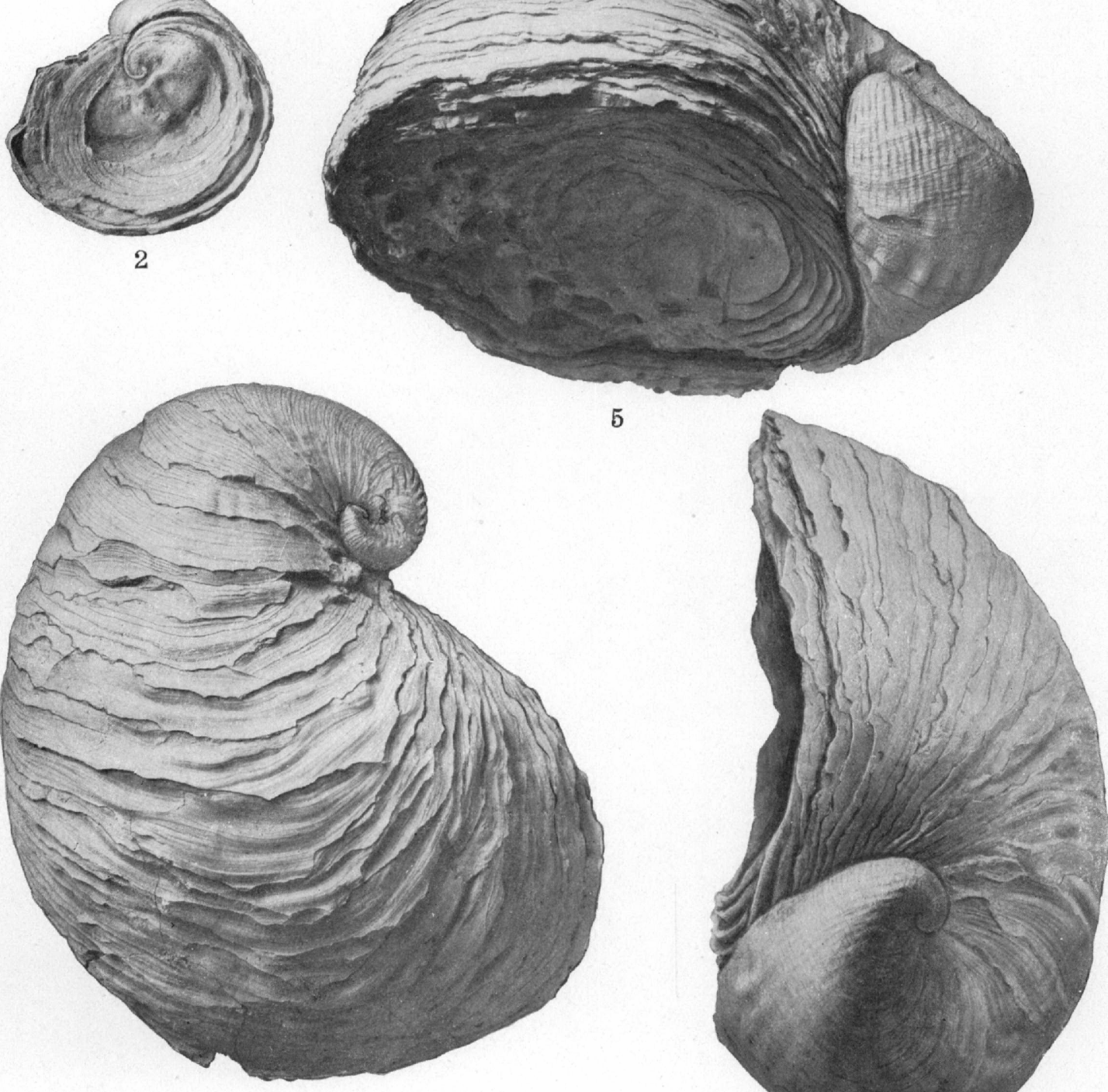

6

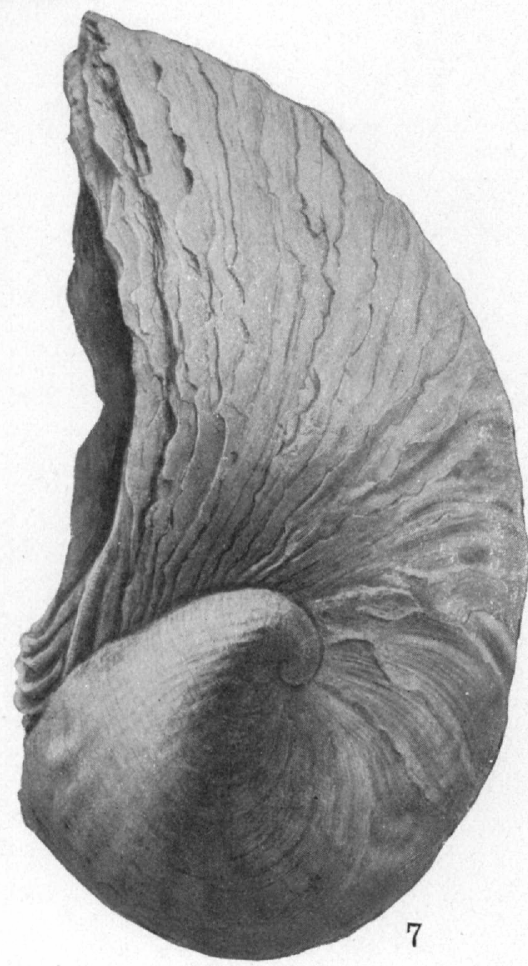

EXOGYRA UPATOIENSIS AND EXOGYRA PONDEROSA ROEMER. 

PLATE XIV. 


\section{PLATE XIV.}

\section{EXogYra PONDERosa Roemer (p. 46).}

Ponderous left or lower valve from the Tombigbee sand member of the Eutaw formation' (Exogyra ponderosa zone, Mortoniceras subzone); Plymouth Bluff, Tombigbee River, 4 to 5 miles northwest of Columbus, Lowndes County, Miss. (U. S. Geol. Survey coll, 6451c). This specimen is devoid of costac. 


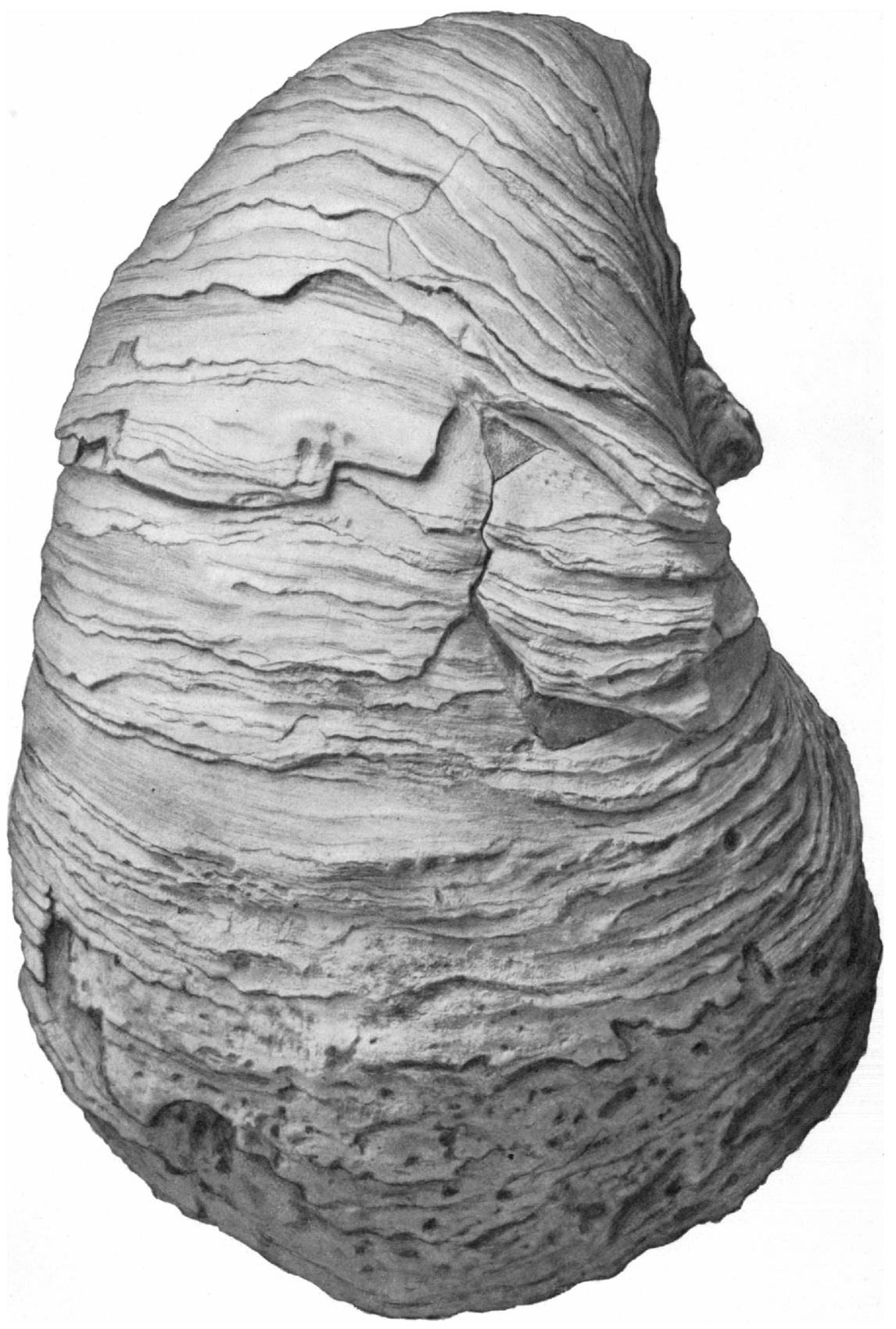

EXOGYRA PONDEROSA ROEMER. 

PLATE XV. 


\section{PLATE XV.}

\section{Exogyra PONDEROSA Roemer (p. 46).}

Figure 1.-Left or lower valve from the Tombigbee sand member of the Eutaw formation (Exogyra ponderosa zone, Mortoniceras subzone); Plymouth Bluff, Chattahoochee River, 4 to 5 miles northwest of Columbus, Lowndes County, Miss. (U. S. Geol. Survey coll. 6918). Shows umbonal ridge well developed.

2.- Right or upper valve of the preceding individual, showing eurface characters.

3.-Interior view of the specimen shown in figure 2 , showing hinge, adductor scar, and other internal characters.

Exogyra ponderosa var. erraticosțata var. nov. (p. 49).

Figure 4.-Left valve from the base of the Selma chalk (Exogyra ponderosa zone, above the Mortoniceras subzone); 1 mile west of Cotton Gin Port, Monroe County, Miss. (U. S. Geol. Survey coll. 6888). Shows typical ornamentation of this variety.

62 

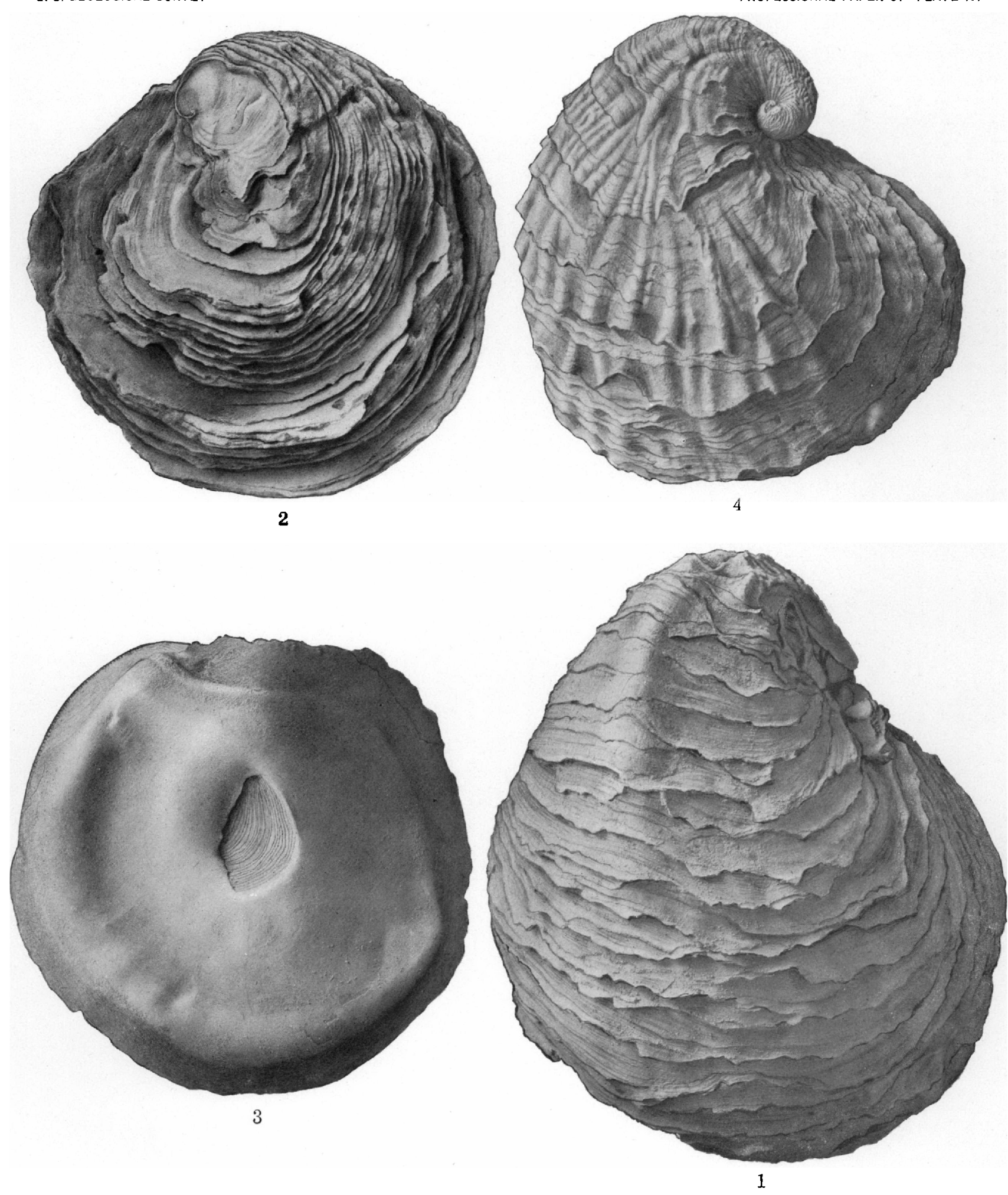

EXOGYRA PONDEROSA ROEMER AND EXOGYRA PONDEROSA VAR. ERRATICOSTATA VAR. NOV. 

PLATE XVI. 


\section{PLATE XVI.}

Exogyra ponderosa var. erraticostata var. nov. (p. 49).

Figure 1.-Left or lower valve from the base of the Selma chalk (Exogyra ponderosa zone, above the Mortoniceras subzone); 1 mile west of Cotton Gin Port, Monroe County, Miss. (U. S. Geol. Survey coll. 6888). Shows a rather weak development of the irregular costæ, with fine costæ well developed on the beak; the irregular costie are well developed on the anterior portion of shell (which does not show in plate).

2.-Exterior view of right valve of the preceding individual.

\section{Exogyra costata Say (p. 50).}

Figure 3.-Left valve from the Ripley formation (Exogyra costata zone); Johnsons Hill, 4 miles north of Lumpkin, Stewart County, Ga. (U. S. Geol. Survey coll. 6418e). Shows the regular costæ typically developed. 4.-Another view of the preceding specimen. 

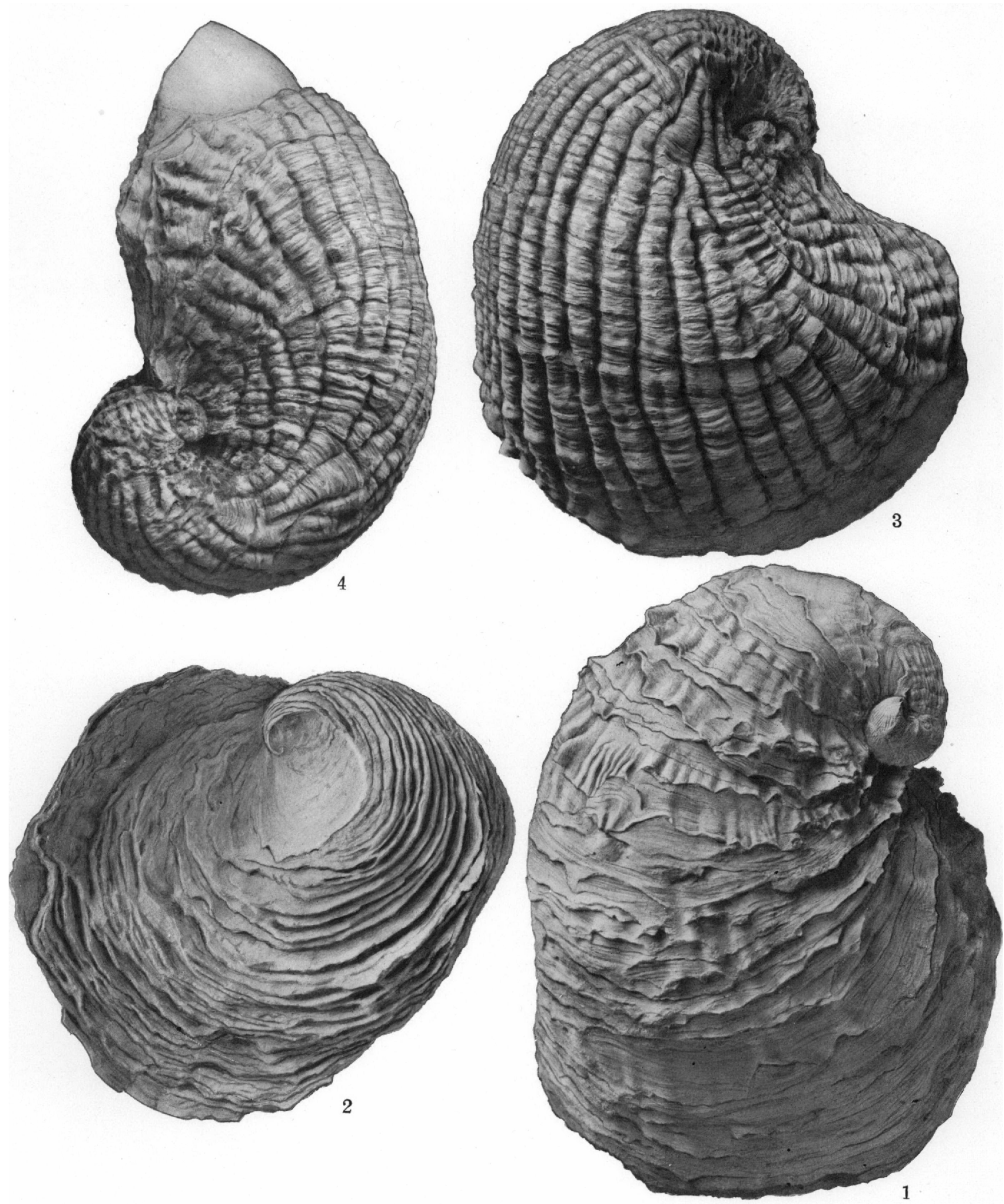

EXOGYRA PONDEROSA VAR. ERRATICOSTATA VAR. NOV. AND EXOGYRA COSTATA SAY. 

PLATE XVII.

$105^{\circ}-$ No. $_{0} 81-14-5$ 


\section{PLATE XVII.}

\section{Exogyra costata Say (p. 50).}

Figure 1. Exterior view of right or upper valve from the Ripley formation (Exogyra costata zone); Johnsons Hill, 4 miles north of Lumpkin, Stewart County, Ga. (U. S. Geol. Survey coll. 6418c). Shows surface characters; costæ faintly developed.

2. Left valve from the Selma chalk (near base of Exogyra costata zone); "Bald Knob" on Joseph Reynolds place, 3 miles west of Corinth, Alcorn County, Miss. (U. S. Geol. Survey coll. 6459). Shows coarser, wider costæ than on typical specimens and a rather strong development of concentric growth projections, also a very large scar of attachment. 


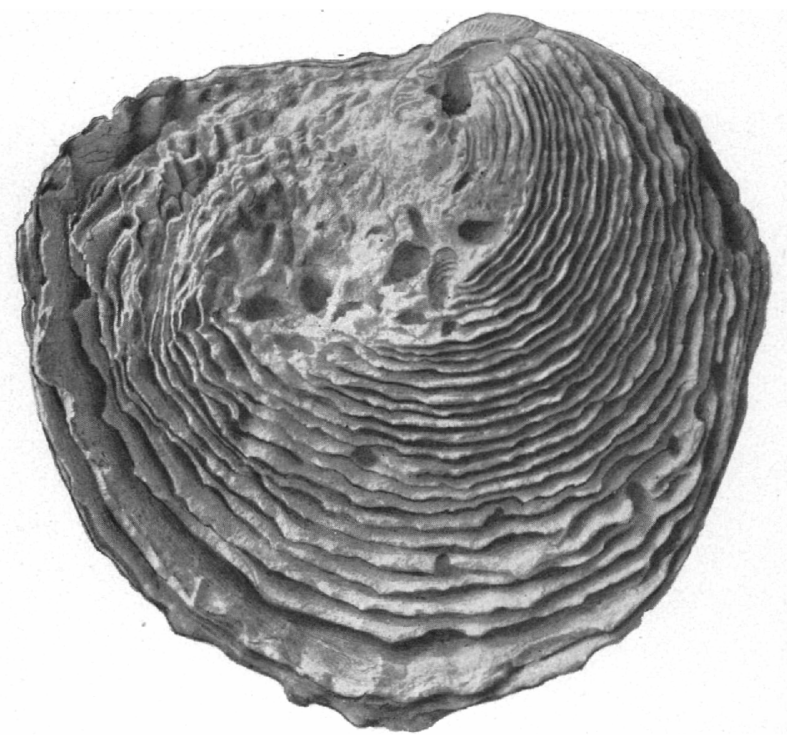

1

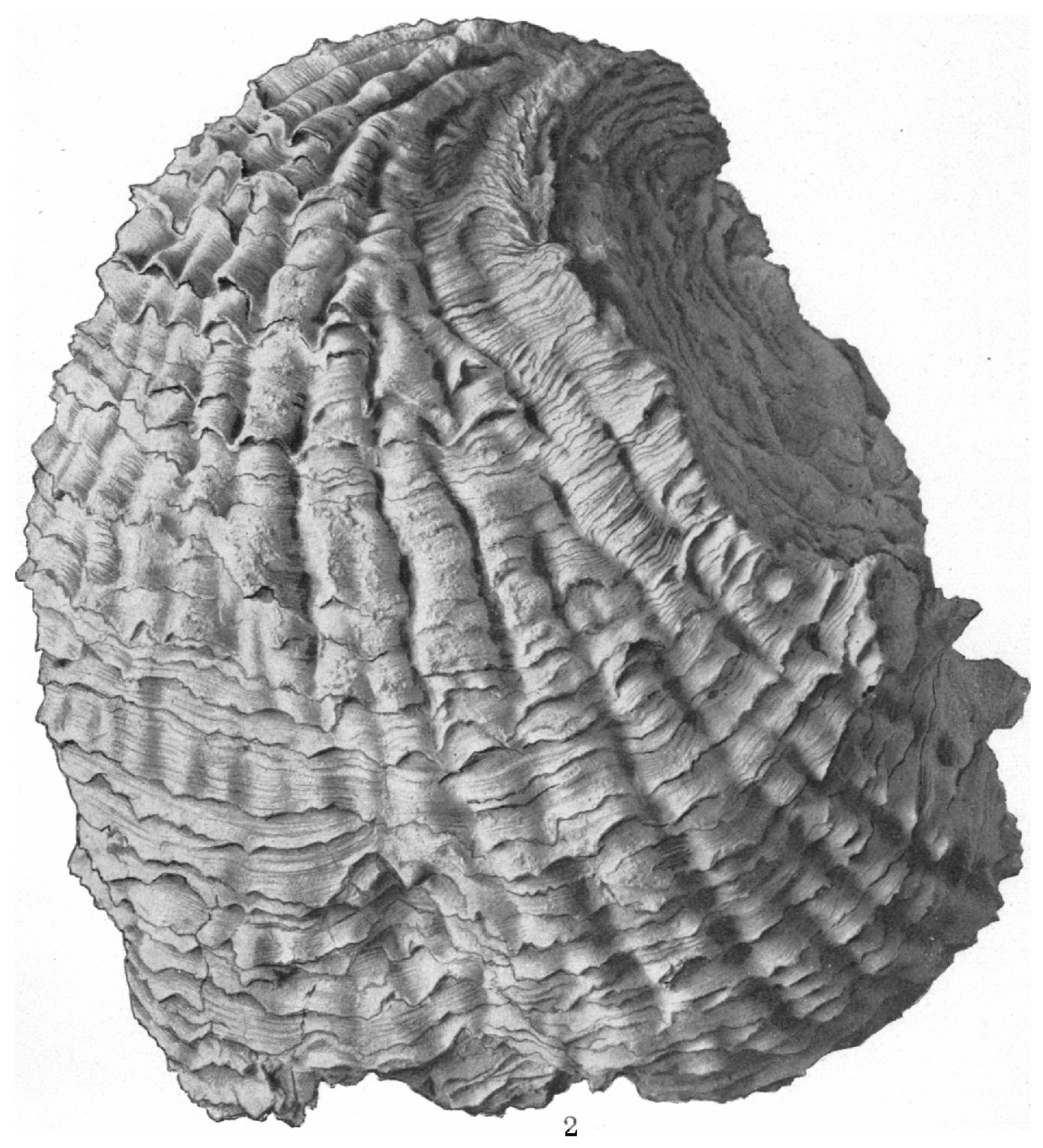

EXOGYRA COSTATA SAY. 

PLATE XVIII. 


\section{PLATE XVIII.}

Exogyra costata Say (p. 50).

Ponderous left valve from the Selma chalk (Exogyra costata zone); 6 miles north of Scooba, on Wahalak-Binnsvill: road, westward-facing slope of Wahalak Creek valley, Kemper County, Miss. (U. S. Geol. Survey coll. 6480d). Shows the absence or faint development of costæ toward the margin of a large overgrown specimen.

68 


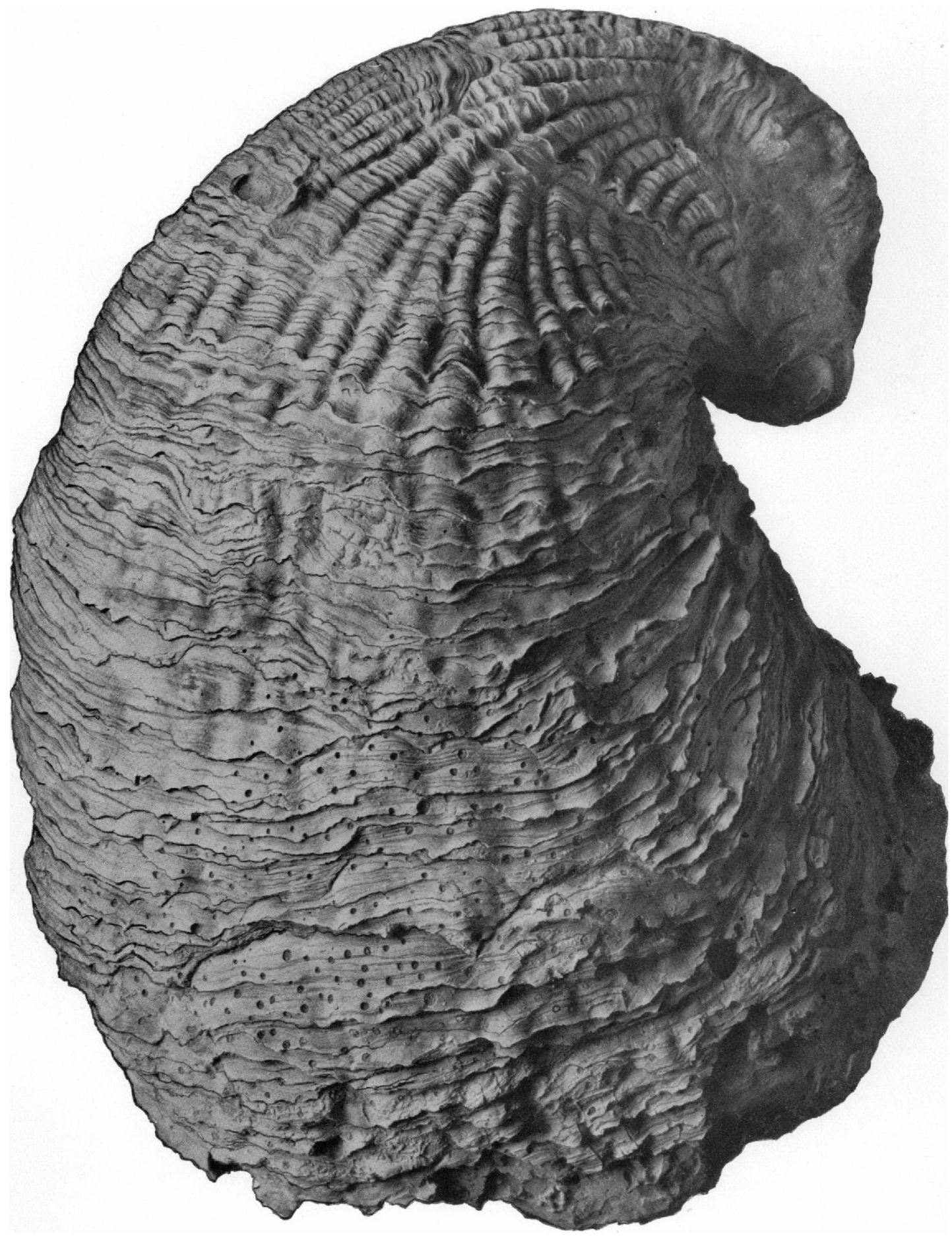

EXOGYRA COSTATA SAY. 

PLATE XIX. 


\section{PIAATE XIX.}

Exogria costata Say (p. 50).

FIGURe 1. Left valve from the Peedee sand; Robinsons Landing, Cape Fear River, 50 miles above Wilmington in Bladen County, N. C. (U. S. Geol. Survey coll. 3356). Shows extreme development of concentric lamellæ.

2. Interior view of same specimen showing hinge, adductor scar, and other internal characters.

3. Left valve from tongue of Selma chalk at top of Cretaceous (Exogyra costata zone, Liopistha protexta subzone); Old Canton Landing, Alabama River, Wilcox County, Ala. (U. S. Geol. Survey coll. 6439). Shows narrow costæ characteristic of specimens from this subzone.

4. Left valve from the Ripley formation (Exogyra costata zone, approximately the Liopistha protextasubzone); Owl Creek, 3 miles northeast of Ripley, Tippah County, Miss. (U. S. Geol. Survey coll. 6464). This specimen also illustrates the narrow costæ characteristic of specimens from the Liopistha protexta subzone. 
U. S. GEOLOGICAL SURVEY

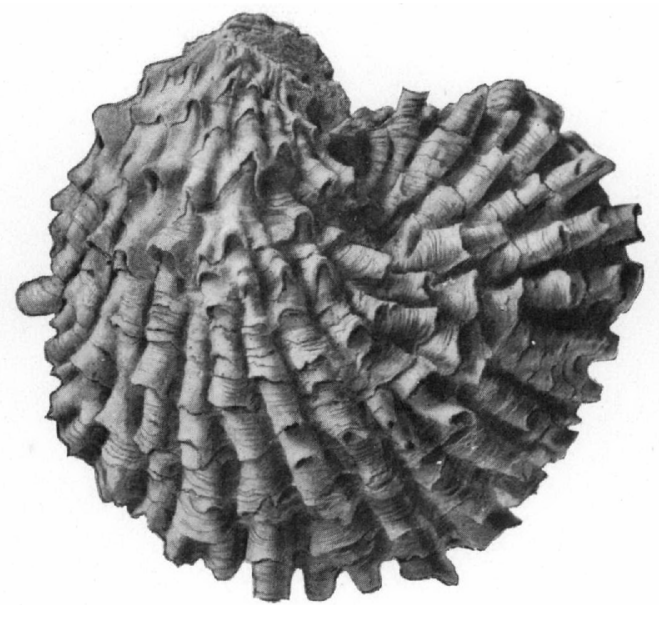

1
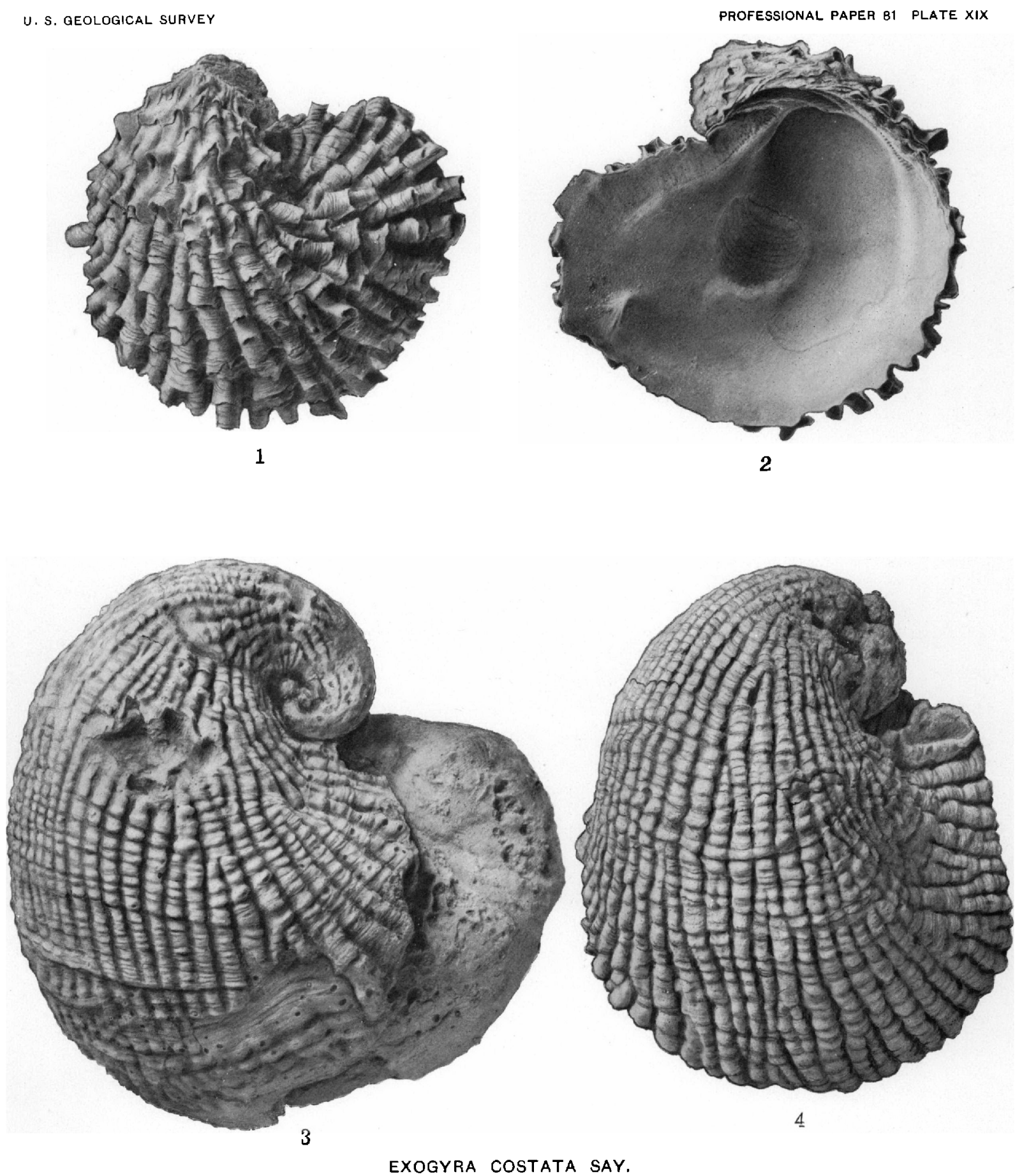



\section{PLATE XX.}




\section{PLATE XX.}

Exogrra costata Say (p. 50).

Figure 1. Specimen with valves attached, from the Ripley formation (Exogyra costata zone); Chattahoochee River, opposite the mouth of Burstahatchee Creek, $5 \frac{1}{2}$ miles above Eufaula, Ala. (U. S. Geol. Survey coll. 6398). Shows right or upper valve with costæ more strongly developed than normal, and costæ toward apical portion of left valve.

Exogrra costata var. Cancellata var. nov. (p. 53).

Figure 2. Left or lower valve from the Selma chalk (Exogyra costata zone); West Point-Cedar Bluff road, 1 mile east of Cedar Bluff, near west end of bridge over Line Creek, Clay County, Miss. (U. S. Geol. Survey coll. 6862 ). Shows characteristic ornamentation of surface.

3. Left valve from impure phase of the Selma chalk (toward base of Exogyra costata zone); cut of Southern Railway $2 \frac{3}{4}$ miles west of Corinth, Alcorn County, Miss.(U. S. Geol. Survey coll. 6879). Shows character of ornamentation on apical portion of shell.

4. Left valve from the Selma chalk (Exogyra costata zone); exposure in public road, 3 miles northwest of Macon, Noxubee County, Miss. (U. S. Geol. Survey coll. 6840). Shows extreme development of concentric ridges. 
U. S. GEOLOQICAL SURVEY

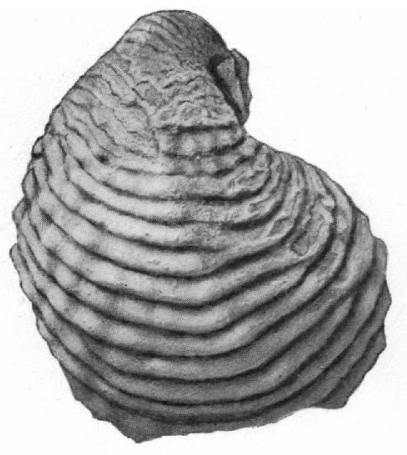

4

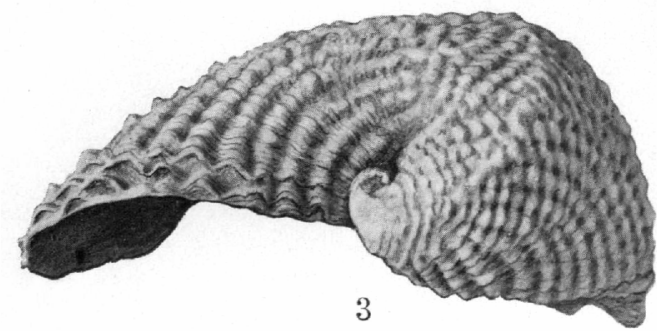

3
PROFESSIONAL PAPER 81 PLATE $X X$

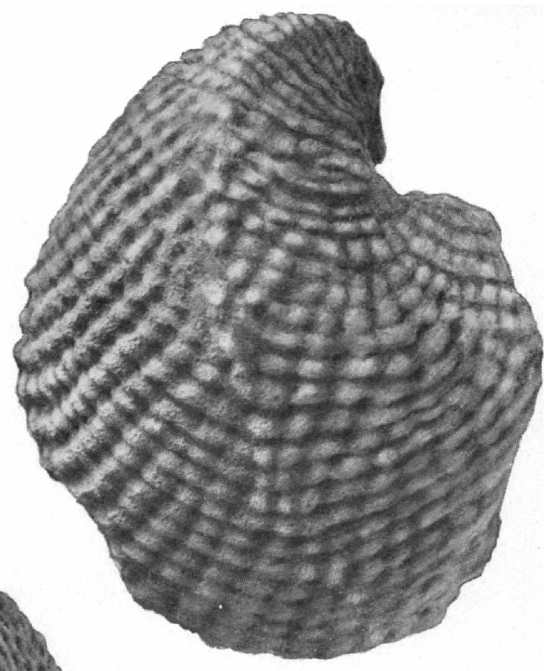

2

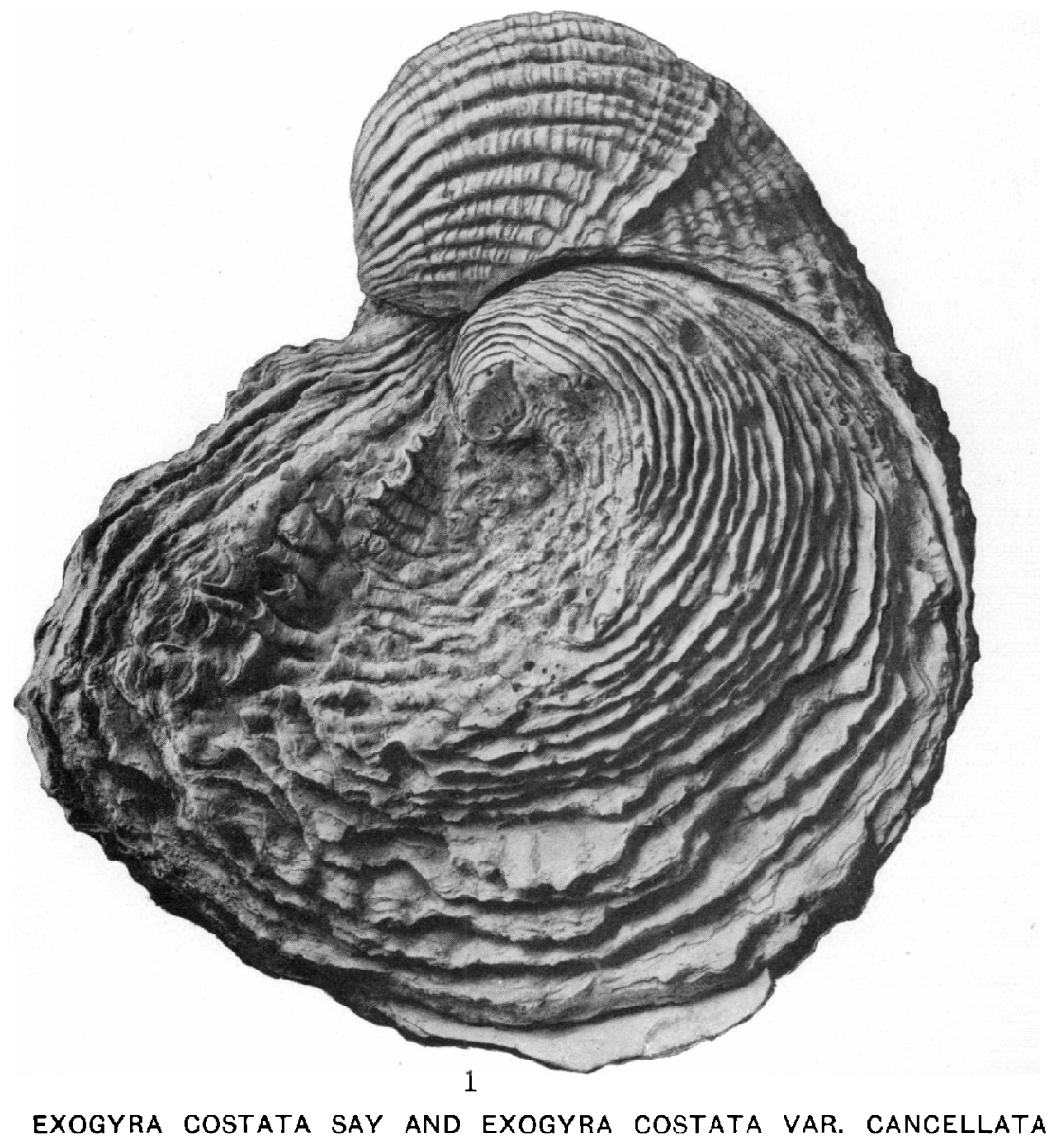
VAR. NOV. 

PLATE XXI. 


\section{PLATE XXI.}

Exogrra costata var. cancellata var. nov. (p. 53).

Figure 1.-Right or upper valve from the Selma chalk (Exogyra costata zone); gullies near public road $3 \frac{1}{2}$ miles northwest of Booneville, Prentiss County, Miss. (U. S. Geol. Survey coll. 6456). Shows the surface characters of this valve.

2.-Left valve from impure phase of Selma chalk (Exogyra costata zone); Selmer-Adamsville road, 3 miles west of Adamsville, McNairy County, Tenn. (U. S. Geol. Surv. coll. 6927). Shows absence of radiating costæ toward margin of a large specimen, and depressed area extending from back to lower posterior margin. 


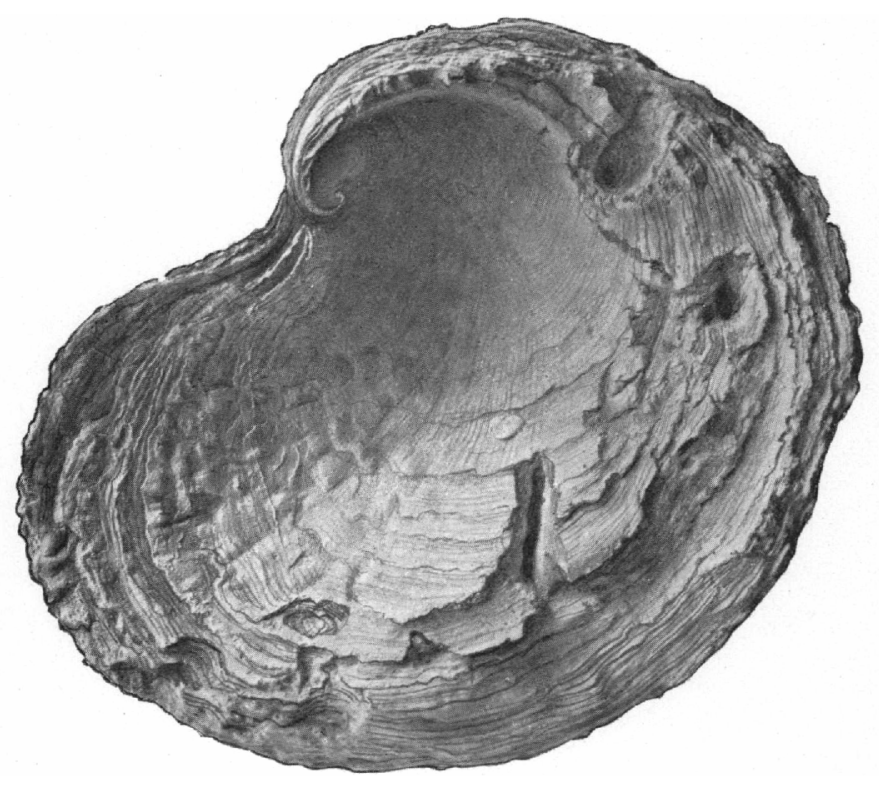

1

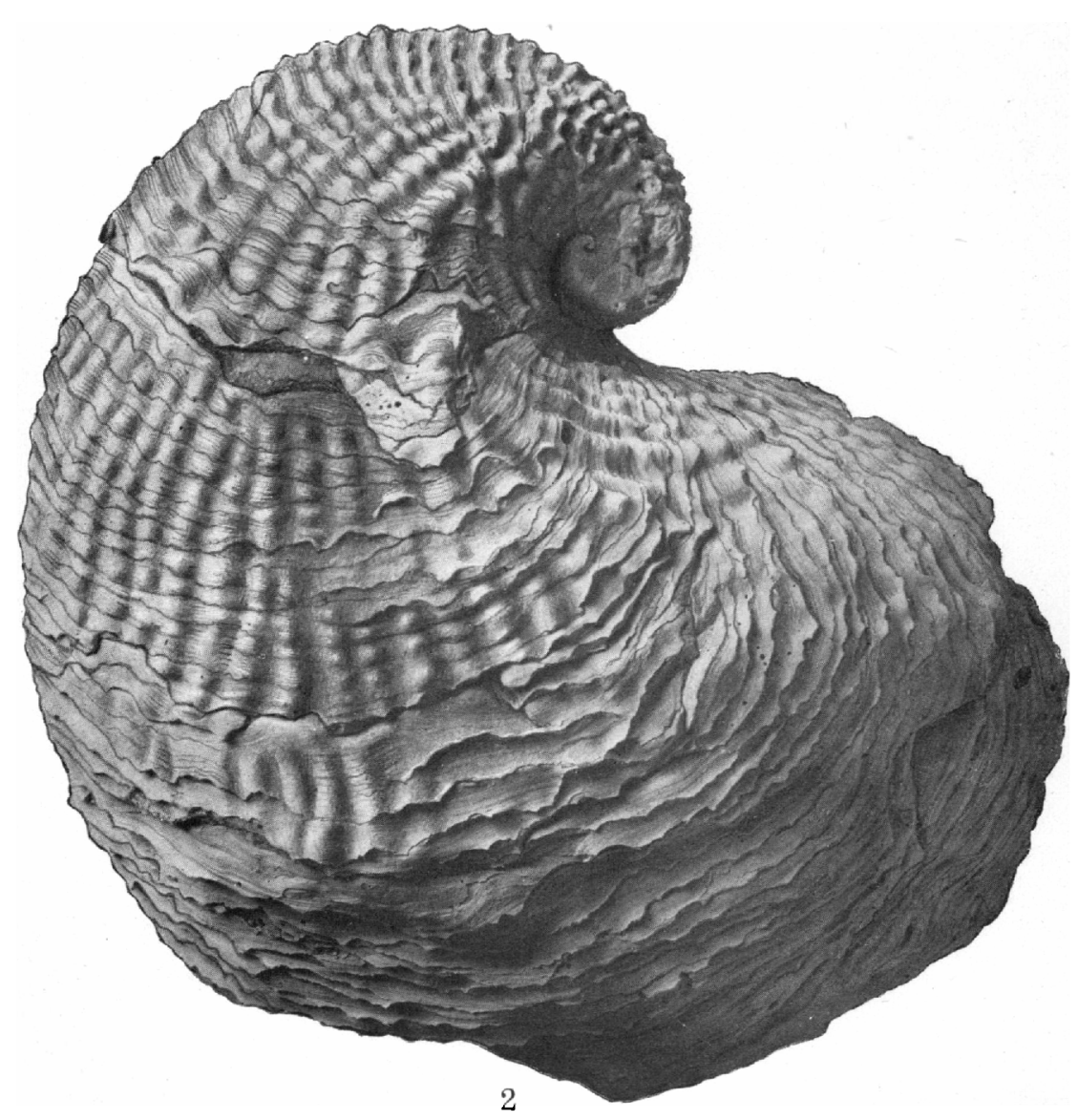

exogyra costata Var. CANGellatavar. NOV. 



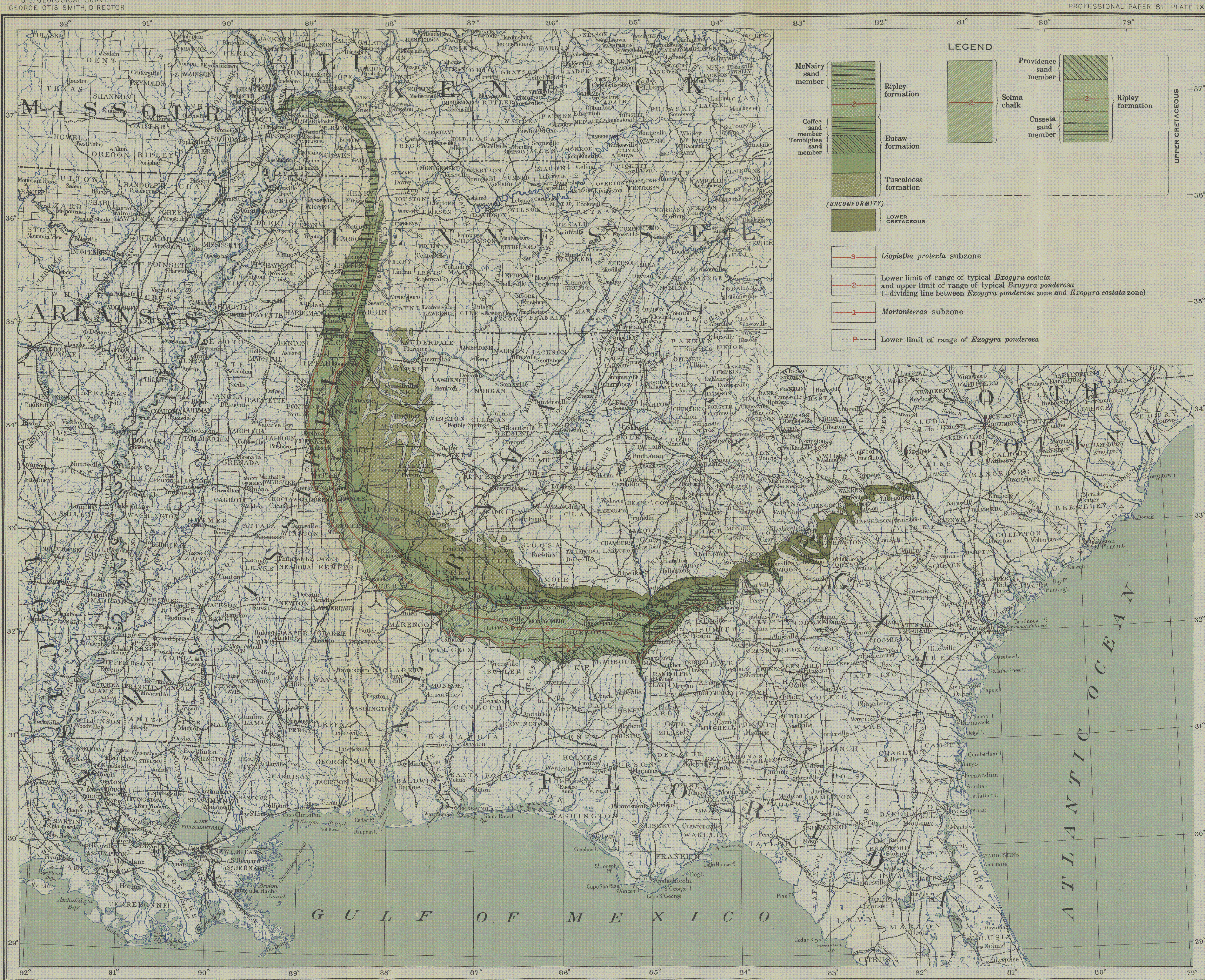

MAP SHOWING THE DISTRIBUTION OF THE LITHOLOGIC DIVISIONS OF THE EASTERN GULF CRETACEOUS DEPOSITS AND THEIR AGE EQUIVALENCIES The boundaries of the divisions have been compiled in part from the published maps of previous investigators and in part from the field notes of the author 



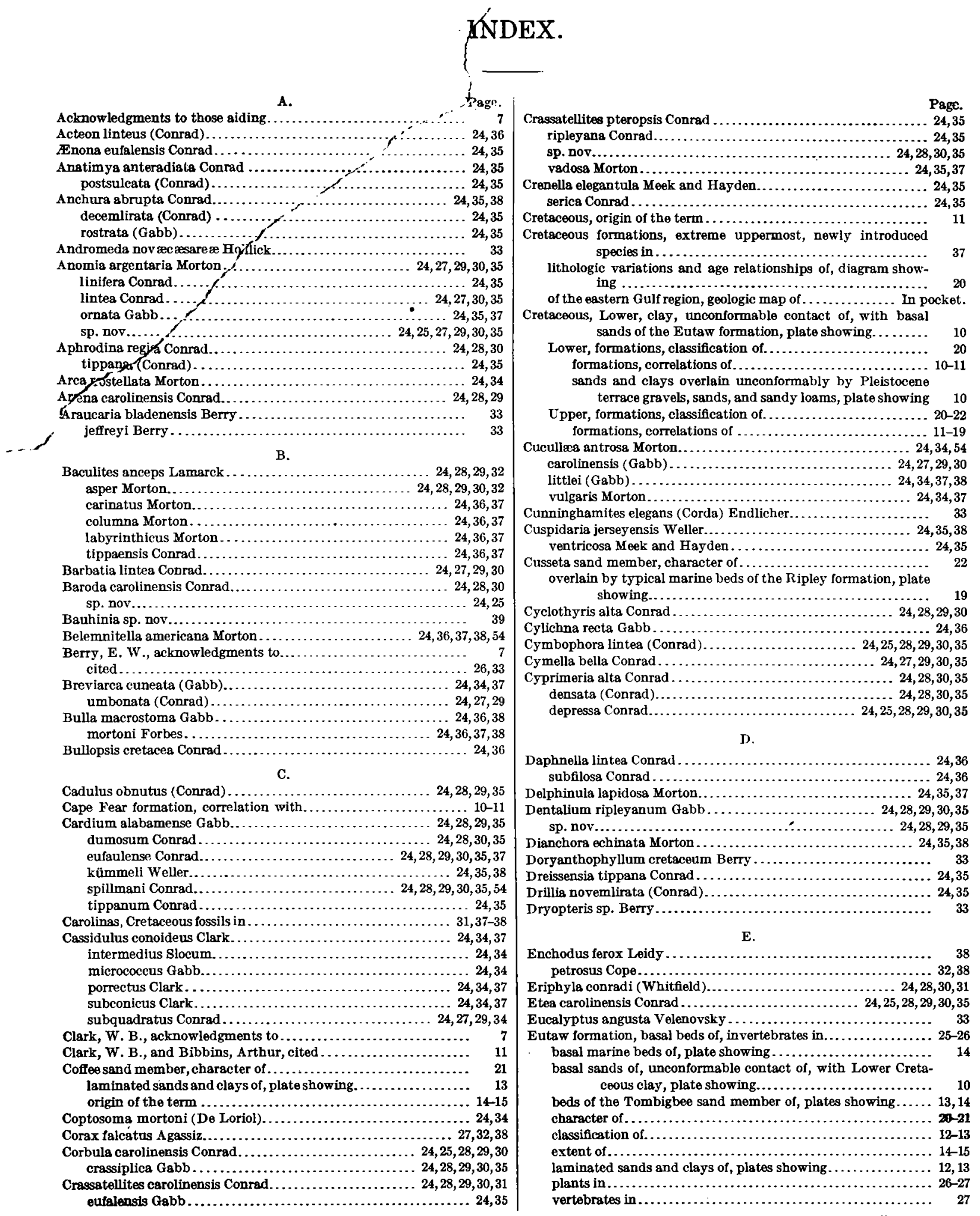


Exogyra, definition of

Page. geologic range of. ranges of, diagram showing. weathered from Selma chalk, plate showing

Exogyra costate Say, description of .

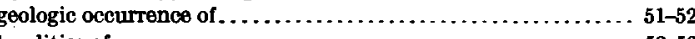
localities of. $17,18,19,31,34,35,37,38,5$

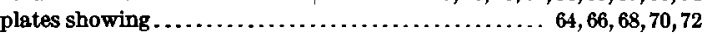
plates st $24,44,45$

xogyra costata var. cancellate var. nov., description of .......... geologic occurrence of localities of...

occurrence of...... proposal of name. range of...

xosta costata zone, extent and position of

fossils in. plants in..... vertebrates in

Exogyra ponderose Roemer, description of geologic occurrence of localities of. occurrence of.

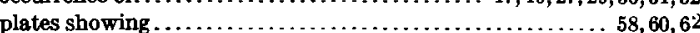
range of

$24,43-44,45$

Exogyra ponderosa var. erraticostata var. nov., description of. geologic occurrence of. . loealities of.

occurrence of. plates showin proposal of name. range of

$34-36$

, correlation of ...................... 31-34 extent and position of . . . . . . . . . . . . . . . . . . . . . . . fossils in ........................................ 27-28 plants in.

subzone of, above Mortoniceras subzone, fossils in . . . . . . . . . 30-31 vertebrates in .................

Exogyra upatolensis sp. nov., description of . . . . . . . . . . . 42,46

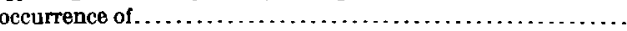

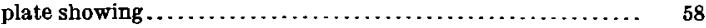
range of .

\section{F.}

Faunal zones and subzones, discrimination of .............. 23-24 generalized section showing.

iern, not determinable.

Ficus sp. nov.

ils, Cretaceous, areas of collections of, map showing Cretaceous, localities of range of, Chattahoochee River and Georgia, table showing. east of Mississippi River, table showing . in east-central Mississippi, table showing . in northern Mississippi, tables showing in region of $\Lambda$ labama River, Ala., table showing.... in region of Chunnenugga Ridge, $\Lambda$ la., table showing. in region of Warrior and Tombigbee rivers, Ala., table showing ...

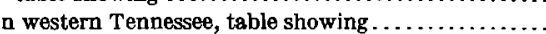

Fusus holmesianus Gabb. novemliratus Conrad. tippanus Conrad

G.

Galeocerdo sp

Gari elliptica Gabb.

Gastrochæna americana Gabb..

Gervilliopsis ensiformis (Conrad)

$$
\text { sp. nov.. }
$$

Gidley, J. W., acknowledgments to

Gilmore, C. W., acknowledgments to.

G'lycymeris subaustralis (D'Orbigny)

Gryphæa aucella Roemer .

vesicularis Lamarck.
Gyrodes abyssina (Morton)

Page. $\ldots .24,28,29,35$ crenata Conrad............................ 24, 28, 29, 30, 35

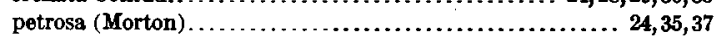

\section{H.}

Hamburg beds, correlation with.... 10-11

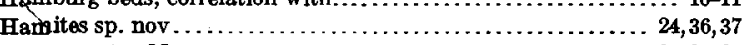

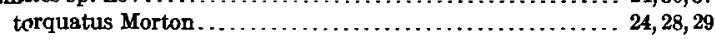

Hamulus major Gabb. . . . . . . . . . . . . . . . . . . . . . . 24, $7,29,30$ nyyx Morton............................... 24, 27, 29, 30,34 squamosus Gabb.............................. 24,27,29,30,34

Herilaster lacunosus Slocum .......................... 24, 34, 37

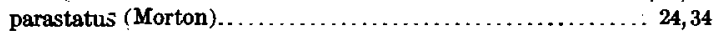
unguls (Mortin) $\ldots \ldots \ldots \ldots \ldots \ldots \ldots \ldots \ldots \ldots \ldots \ldots \ldots \ldots \ldots \ldots \ldots, 24,34$

Hemiptychodus moi toni Mantell........................ 32, 33

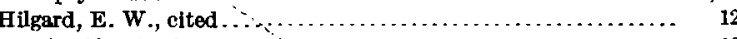
classification by ................................... 12

I.

Inoceramus argenteus Conrad $\ldots \ldots \ldots \ldots \ldots \ldots \ldots \ldots \ldots \ldots \ldots \ldots, \mathbf{2 4}, \mathbf{3 4}$

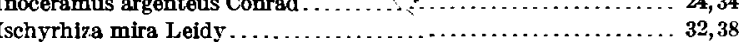
Isocardia cliff woodensis $W$ eller............................ 28, 30,31

Johnson, L. C., and Smith, E. A., classification by ............ 12 Johnson, L. C., Smith, E. A., and Langdon, D. W., jr., cited..... 15, 16

texana Roemer. Langdon, D. W., jr., Smith, E. A., and Johnson, L. C., cited.... 15, 16 Laurus sp.......................................... Laxispira lumbricalis Gabb. . . . . . . Leda longifrons Conrad......................... 24, 27, 29,30,34 pinnaforma Gabb.......................... 24,27,30,34 protexta Gabb.............................. 24, 27,30,34

Legumen planulatum (Conrad) $\ldots \ldots \ldots \ldots \ldots \ldots \ldots \ldots \ldots \ldots \ldots \ldots \ldots \ldots \ldots \ldots .24,28,29,30,35$

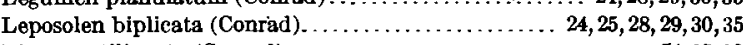
Lima acutilineata (Conrad) . . . . . . . . . . . . . . . pelagica (Morton) $\ldots \ldots \ldots \ldots \ldots \ldots \ldots \ldots \ldots \ldots \ldots \ldots, 24,27,29,35$ reticulata Forbes........................... 24, 27, 29,30,35

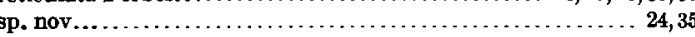
Linearia metastriata Conrad . . . . . . . . . . . . . . . . . . 24, 28, 29,35 ornatissima Weller..........................24, 28,30,35

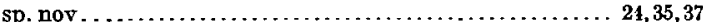

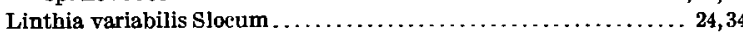

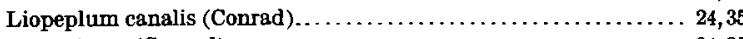
cretacea (Conrad) $\ldots \ldots \ldots \ldots \ldots \ldots \ldots \ldots \ldots \ldots \ldots \ldots \ldots, 24,35$ liodermum (Conrad) . . . . . . . . . . . . .

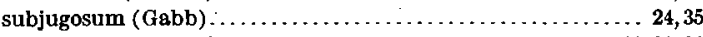
Liopistha alternata Weller . . . . . . . . . . . . . . . 24, 27, 29, 30,31 protexta Conrad . . ............................ 24,35,37,38

sp.

Liopistha protexta subzone, extent and position of............

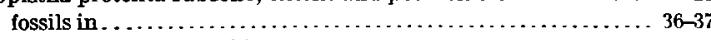
Lithophaga ripleyana Gabb...................... 24,35

Lucina glebula Conrad ........................... 24, 28, 29,30

Lunatia obliquata Meek and Hayden............ 24, 28, 29, 30,35

\section{M.}

MeNairy sand member, beds of, plate showing ..............

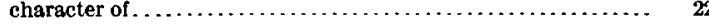

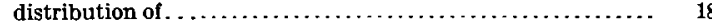
origin of name $. \ldots \ldots \ldots \ldots \ldots \ldots \ldots \ldots \ldots \ldots \ldots \ldots \ldots \ldots \ldots \ldots, 17-18$

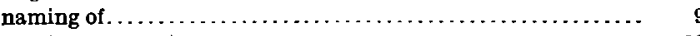

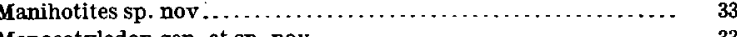
Monocotyledon gen. et sp. nov . . . . . . . . . . . . . . . . . . . Morea cancellaria Conrad............................ 24,35 Morton, S. G., correlation by ............................. 11 Mortoniceras delawarense (Morton) $\ldots \ldots \ldots \ldots \ldots \ldots \ldots \ldots \ldots \ldots \ldots, 30,32$ texanum (Roemer) var . . . . . . . . . . . . . . . . 24, 28, 29, 30,32

Mortoniceras subzone, extent of . ................... 23, 28-29 fossils in . . . . . . . . . . . . . . . . . . . . . . . . . . . . . position of $\ldots \ldots \ldots \ldots \ldots \ldots \ldots \ldots \ldots \ldots \ldots \ldots \ldots \ldots \ldots, \quad 23$

$\mathrm{S}$

Nautilus dekayi Morton.......................... 24,36,37,38 sp. nov . .................................. 24, 28, 29

Nemodon brevifrons Conrad . . ..................... 24,27,30,34 eufalensis (Gabb) . . . . . . . . . . . . . . . . . . . . .

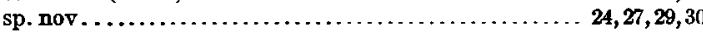


New Jersey, Cretaceous fossils in. Nomenclature, readjustment of.

Nucula cuneifrons Conrad. eufalensis Gabb percrassa Conrad. sp. $24,27,29,34$ $24,25,27,29,30,34$ $24,27,29,30$

o.

Object of the work on Cretaceous deposits. Ostrea cretacea Morton. viana Linnæus.

larva Lamarck panda Morton. peculiaris Conrad plumosa Morton

sp.

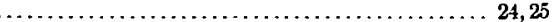
sp. nov ................................ 24, 25, 27, 29, 30, 34 subspatulata Forbes............................... 24, 34,38 tecticosta Gabb... $24,27,29,30,34$ Otodus appendiculatus Agassiz$$
\text { P. }
$$

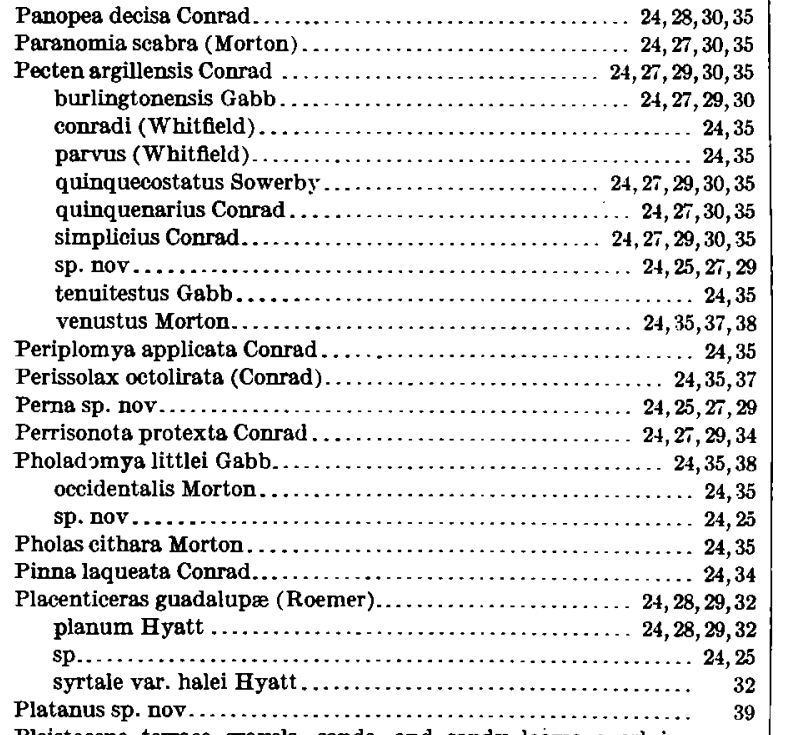

Pleistocene terrace gravels, sands, and sandy loams overlying Lower Cretaceous sands and clays, plate showing...

Pleurotoma laqueata (Conrad). melanopsis (Conrad)

Plicatula sp. nov.

Polydectes biturgidus Cope

Protocardium sp. nov.

Providence sand member, beds of plate showing............ 24,35 eharacter of .

Pteria petrosa (Conrad)

Pterocerella tippana (Conrad)

Ptychodus martini Williston

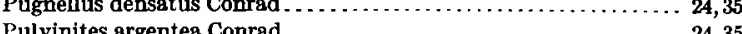

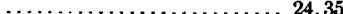

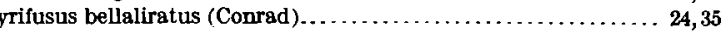
subdensatus Conrad................................. 24,35 Pyropsis perlata Conrad $\ldots \ldots \ldots \ldots \ldots \ldots \ldots \ldots \ldots \ldots \ldots \ldots \ldots \ldots \ldots \ldots \ldots \ldots, 24,35$

\section{$\mathrm{R}$}

Radiolites austinensis Roemer................. 24, 28, 29, 30,32 sp. nov.

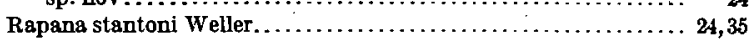

Rhizocrinus alsbamensis De Loriol ..................... 24,34

Ringicula pulchella Shumard ......................... 24,36

Ripley formation; beds of MeNairy sand member of, plate showing. beds of Providence sand member of, plate showing. character of... classic fossil locality of, plate showing
Ripley formation, Cusseta sand member of, overlain by typical marine beds of, plate showing $\ldots \ldots \ldots \ldots \ldots \ldots \ldots \ldots \ldots, 19$

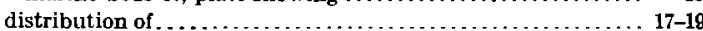
marine beds of, plate showing ................. 18, 19

s.

Salix eutawensis Berry $\ldots \ldots \ldots \ldots \ldots \ldots \ldots \ldots \ldots \ldots \ldots \ldots \ldots, \mathbf{2 1}, \mathbf{2 6}$

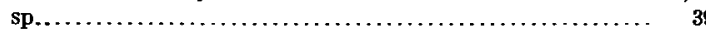

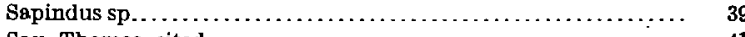

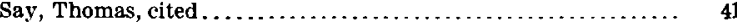
Scala sillimani (Morton) . . . . . . . . . Scambula perplana Conrad............................. 24, 28,30,35 Scaphites conradi (Morton) .......................... 24,36,37 Schizodesma appressa Gabb..................... 24, 28, 29, 30,35 Scope of the work on Cretaceous deposits.................... $9-10$ Selma chalk, character and distribution of ................... 15-16, 21 deposition of ..................................... 16-17

Exogyra from, plate showing........................ typical exposures of, plate showing................... 16

Serpula barbata Morton.............................. 24,34 cretacea (Conrad) ......................... 24, 27,30,34 sp...................................... 24, 27,29,34 Sloan, Earle, acknowledgments to ......................... Smith, E. A., acknowledgments to.......................... 7 Smith, E. A., and Johnson, L. C., classification by ............. 12 Smith, E. A., Langdon, D. W., jr., and Johnson, L. C., cited.... 15, 16 Sphærella concentrica Conrad .............................24,35

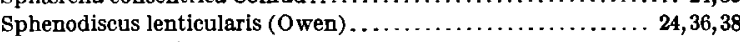
pleurisepta (Conrad) ............................. 44,36

Stanton, T. W., acknowledgments to . ..................... 7

Strepsidura interrupts (Conrad) $\ldots \ldots \ldots \ldots \ldots \ldots \ldots \ldots \ldots \ldots, 24,35$

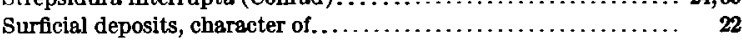

T.

Tenes pinguis (Conrad) $\ldots \ldots \ldots \ldots \ldots \ldots \ldots \ldots \ldots \ldots \ldots \ldots, 24,28,29,35$

Texss, Cretaceous fossils in.............................. 32,38

Terebratulina filosa Conrad ..............................

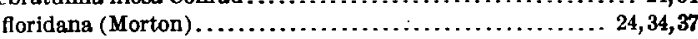

Thecachampsa rugosa Emmons .......................... 33

Tombigbee sand member, character of $\ldots \ldots \ldots \ldots \ldots \ldots \ldots \ldots \ldots$, 21 classification of . .................................. 12-13 typical beds of, plate showing ........................... 13,14

Trichoptropis cancellaria Conrad ....................... 24,35

Trigonia angulicostata Gabb $\ldots \ldots \ldots \ldots \ldots \ldots \ldots \ldots \ldots \ldots \ldots \ldots \ldots \ldots \ldots \ldots \ldots, 24,35$ eufalensis Gabb.............................. 24,27,29, 35 sp. nov ..................................... 24, thoracica Morton............................ 24,35,37

Trigonoarca maconensis (Conrad) . . . . . . . . . . . . . . 24, 30

sp. nov . . . . . . . . . . . . . . .

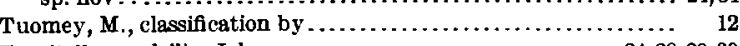

Turritella quadrilira Johnson . . . . . . . . . . . . . . . sp. nov $\ldots \ldots \ldots \ldots \ldots \ldots \ldots \ldots \ldots \ldots \ldots \ldots \ldots \ldots \ldots \ldots .24,35,37$ tippana Conrad $\ldots \ldots \ldots \ldots \ldots \ldots \ldots \ldots \ldots \ldots \ldots \ldots \ldots \ldots \ldots, 24, \mathbf{3 5}$ trilira Conrad ............................... 24, 28,29,30,35 vertebroides Morton . . . . . . . . . . . . . . $\ldots \ldots \ldots \ldots \ldots \ldots, 34,38$ Turrilites alternatus Tuomey $\ldots \ldots \ldots \ldots \ldots \ldots \ldots \ldots \ldots \ldots \ldots .24,36$

Tuscaloosa formation, character of ...................... 20 classification of ................................... 12-13 extent of ............................................ 14 plate showing

V.

Veatch, Otto, acknowledgments to........................... Veniella conradi (Morton) $\ldots \ldots \ldots \ldots \ldots \ldots \ldots \ldots \ldots \ldots \ldots 24,28,29,30,35,64$
Vetericardia crenalirata (Conrad) $\ldots \ldots \ldots \ldots \ldots \ldots \ldots \ldots \ldots .24,28,29,35$ Vetericardia crenalirata (Conrad) $\ldots \ldots \ldots \ldots \ldots \ldots \ldots \ldots \ldots \ldots \ldots \ldots \ldots \ldots \ldots \ldots \ldots \ldots \ldots \ldots \ldots \ldots$
Volutomorpha dumasensis Dall $\ldots \ldots \ldots \ldots \ldots \ldots$ eufalensis (Conrad) $\ldots \ldots \ldots \ldots \ldots \ldots \ldots \ldots \ldots \ldots \ldots \ldots \ldots .24,35$

W

Weller, Stuart, acknowledgments to .......................

Winchell, Alezander, classification by . . ................... 12

$\mathrm{x}$.

Xenophora leprosa (Morton). 
